
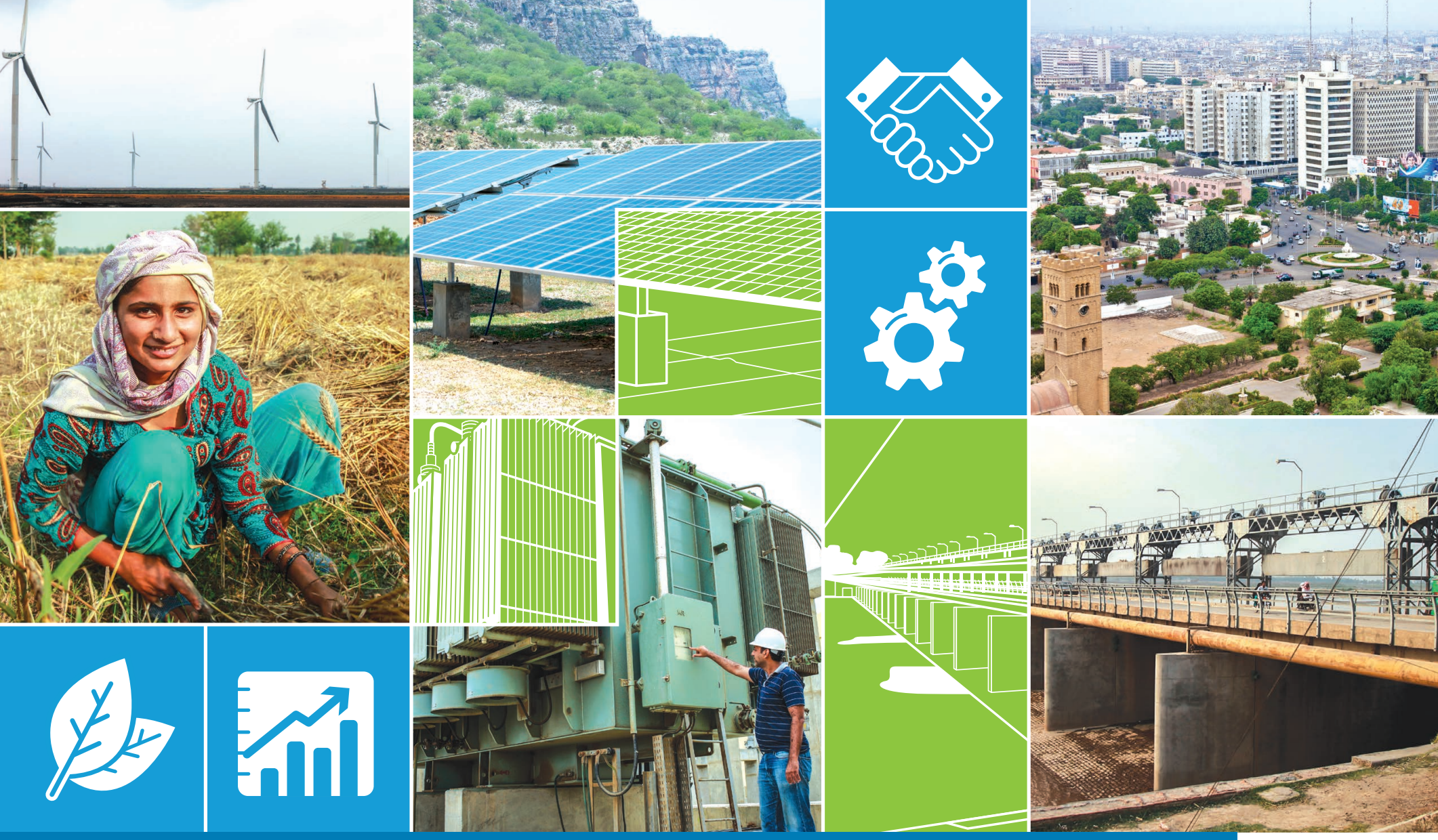

\title{
PUBLIC-PRIVATE PARTNERSHIP MONITOR PAKISTAN
}

JULY 2021 


\section{PUBLIC-PRIVATE PARTNERSHIP MONITOR PAKISTAN}

JULY 2021 
(C) 2021 Asian Development Bank

6 ADB Avenue, Mandaluyong City, 1550 Metro Manila, Philippines

Tel +632 8632 4444; Fax +63286362444

www.adb.org

Some rights reserved. Published in 2021.

Printed in the Philippines

ISBN 978-92-9262-940-3 (print); 978-92-9262-941-0 (electronic); 978-92-9262-942-7 (ebook)

Publication Stock No. SGP210251-2

DOI: http://dx.doi.org/10.22617/SGP210251-2

The views expressed in this publication are those of the authors and do not necessarily reflect the views and policies of the Asian Development Bank (ADB) or its Board of Governors or the governments they represent.

ADB does not guarantee the accuracy of the data included in this publication and accepts no responsibility for any consequence of their use. The mention of specific companies or products of manufacturers does not imply that they are endorsed or recommended by ADB in preference to others of a similar nature that are not mentioned.

By making any designation of or reference to a particular territory or geographic area, or by using the term "country" in this document, $A D B$ does not intend to make any judgments as to the legal or other status of any territory or area.

This work is available under the Creative Commons Attribution 3.0 IGO license (CC BY 3.0 IGO) https://creativecommons.org/licenses/by/3.0/igo/. By using the content of this publication, you agree to be bound by the terms of this license. For attribution, translations, adaptations, and permissions, please read the provisions and terms of use at https://www.adb.org/terms-use\#openaccess.

This CC license does not apply to non-ADB copyright materials in this publication. If the material is attributed to another source, please contact the copyright owner or publisher of that source for permission to reproduce it. ADB cannot be held liable for any claims that arise as a result of your use of the material.

Please contact pubsmarketing@adb.org if you have questions or comments with respect to content, or if you wish to obtain copyright permission for your intended use that does not fall within these terms, or for permission to use the ADB logo.

Corrigenda to ADB publications may be found at http://www.adb.org/publications/corrigenda.

Notes:

In this publication, "\$” refers to United States dollars.

ADB recognizes "China" as the People's Republic of China, "Korea" as the Republic of Korea, and "Vietnam" as Viet Nam.

On the cover:

ADB is supporting the development and delivery of public-private partnership projects in Pakistan to aid in bridging the gap in the country's infrastructure investments (photos by Sara Farid/ADB: wind turbines in Thatta District, woman farmer, wind power generation plant at the Foundation Wind Energy-I Limited, and construction site at the Head Balloki extension project in Punjab; Nasr ur Rahman/ADB: solar panels in Khushab District; and Syed Muhammad Rafiq/ADB: aerial view of Karachi).

Cover design by Claudette Rodrigo. 


\section{Contents}

Tables, Figures, and Box

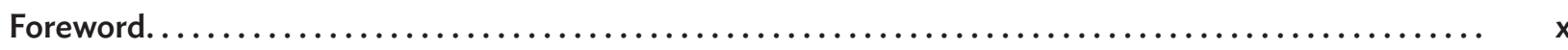

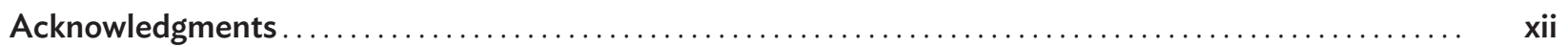

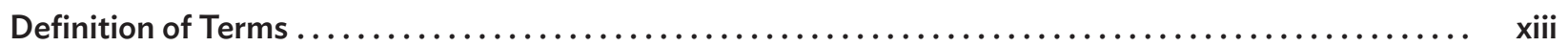

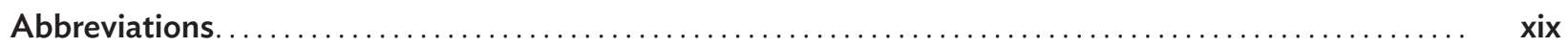

Guide to Understanding the Public-Private Partnership Monitor $\ldots \ldots \ldots \ldots \ldots \ldots \ldots \ldots \ldots \ldots \ldots, \quad$ xxi

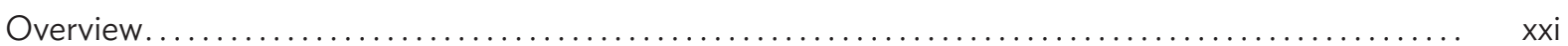

National Public-Private Partnership Landscape Indicators. .............................. xxii

Sector-Specific Public-Private Partnership Landscape Indicators....................... xxiii

Local Government Public-Private Partnership Landscape .............................. xxiv

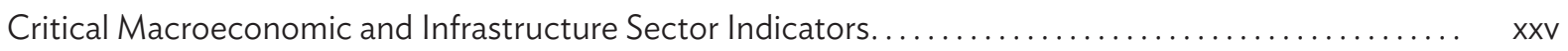

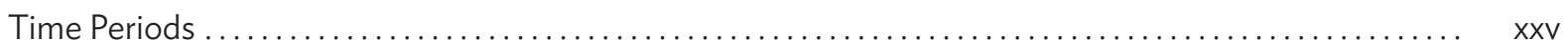

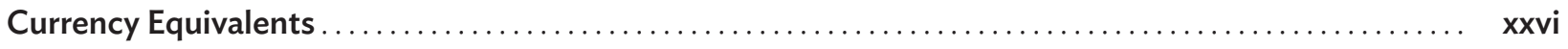

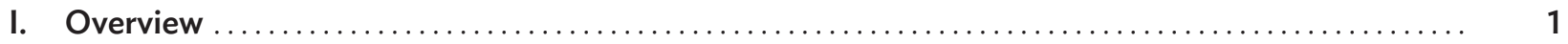

II. National Public-Private Partnership Landscape $\ldots \ldots \ldots \ldots \ldots \ldots \ldots \ldots \ldots \ldots \ldots \ldots \ldots \ldots \ldots \ldots \ldots \ldots$

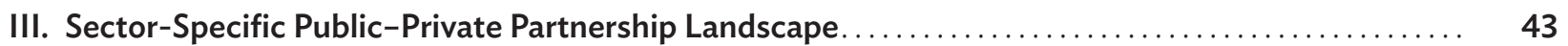

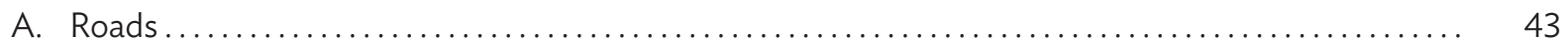

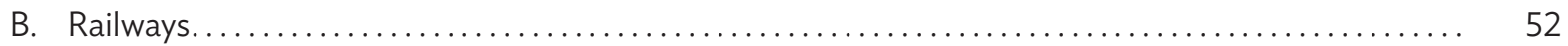

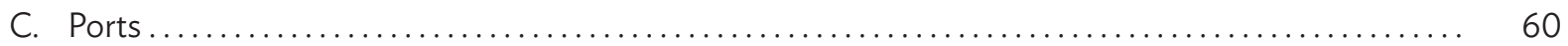

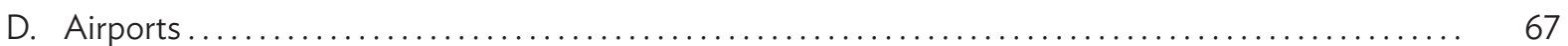

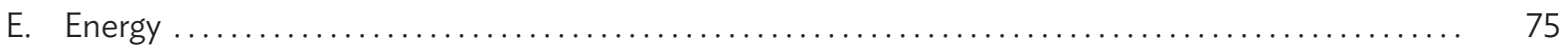

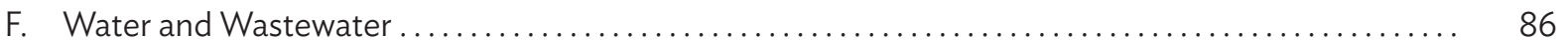

G. Information and Communication Technology..................................... 93

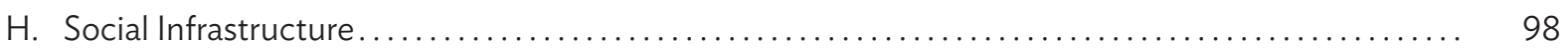

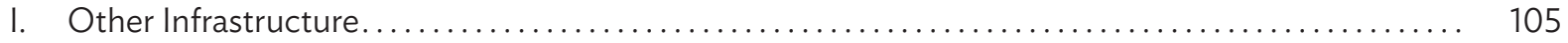


IV. Local Government Public-Private Partnership Landscape

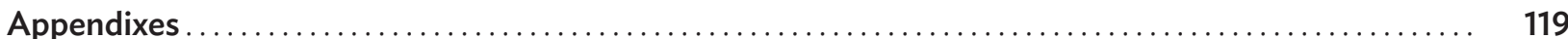

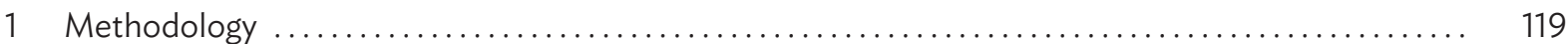

2 Macroeconomic and Infrastructure Sector Indicators of Pakistan . . . . . . . . . . . . . . . . . . . . 149

3 World Bank's Ease of Doing Business Parameters for Pakistan . . . . . . . . . . . . . . . . . . . . . . 154

4 Assessment of Public Financial Management System in Pakistan, 2012 . . . . . . . . . . . . . . . . . 157

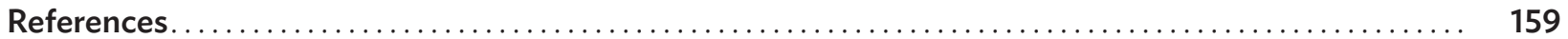




\section{Tables, Figures, and Box}

\section{Tables}

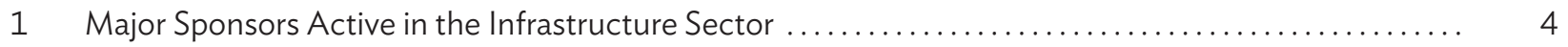

2 Overview of Provincial Public-Private Partnership Frameworks in Pakistan . . . . . . . . . . . . . . . . . 9

3 Types of Public-Private Partnerships in the Provinces of Pakistan $\ldots \ldots \ldots \ldots \ldots \ldots \ldots \ldots \ldots \ldots \ldots, 12$

4 Eligible Sectors and Subsectors for Public-Private Partnerships ............................. 14

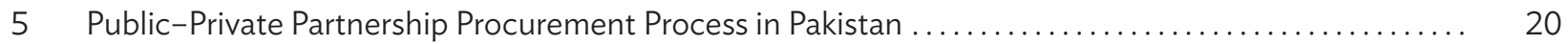

6 Instruments of Federal Government's Financial Support in Pakistan . . . . . . . . . . . . . . . . . . 37

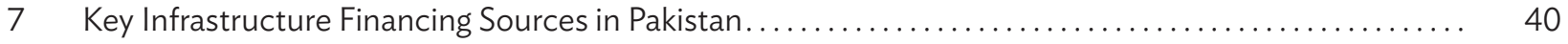

8 Banks in Project Finance in Pakistan in 24 Months Preceding December 2019. . . . . . . . . . . . . . 41

9 Active Project Sponsors in Pakistan in 24 Months Preceding December 2019 . . . . . . . . . . . . . . . . 41

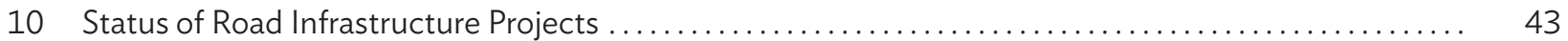

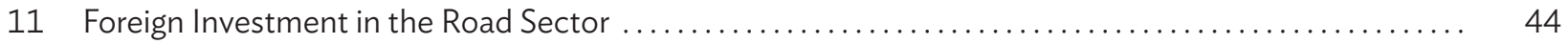

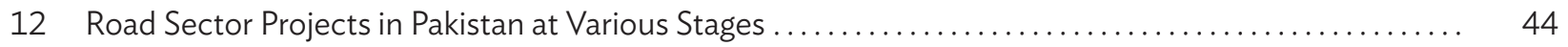

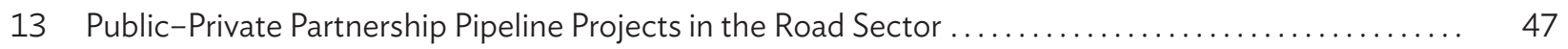

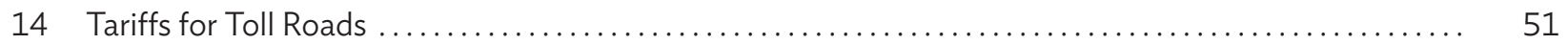

15 Risk Allocation of Public-Private Partnership Projects in the Road Sector. . . . . . . . . . . . . . . . . 51

16 Financing of Public-Private Partnership Projects in the Road Sector ....................... 52

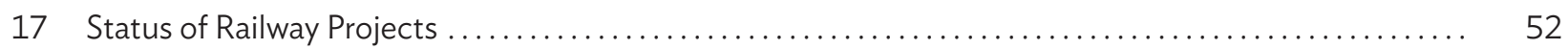

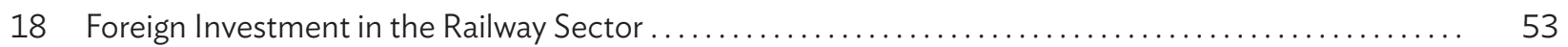

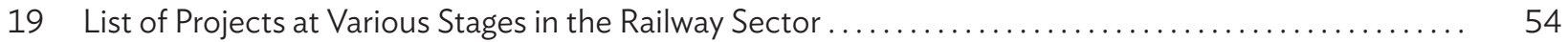

20 Financing of Public-Private Partnership Projects in the Railway Sector....................... 60

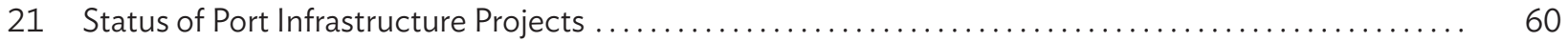

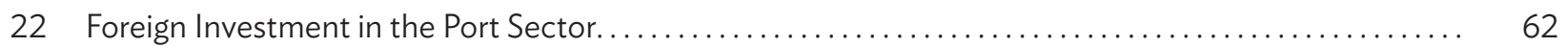

23 Risk Allocation of Public-Private Partnership Projects in the Port Sector . . . . . . . . . . . . . . . . . 66

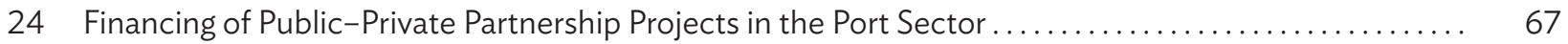

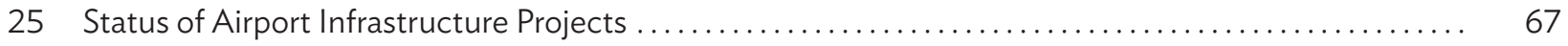

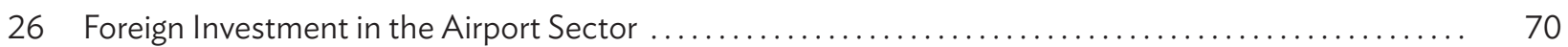


$27 \quad$ Financing of Public-Private Partnership Projects in the Airport Sector. . . . . . . . . . . . . . . . . 74

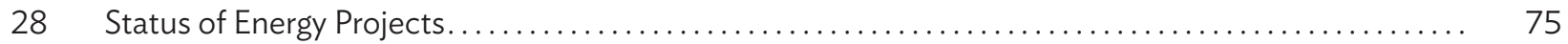

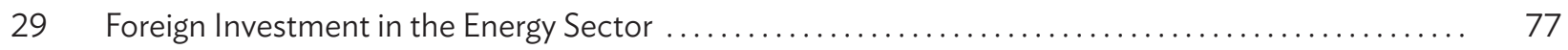

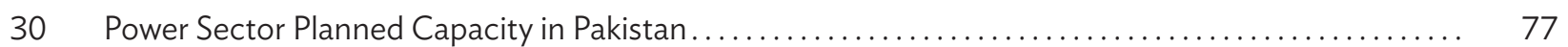

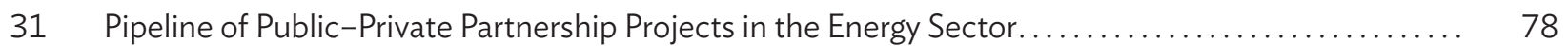

32 Pipeline of Public-Private Partnership Projects in the Energy Sector (Hydropower) .............. 80

33 Tariffs Set by the National Electric Power Regulatory Authority for Energy Projects in Pakistan ...... 85

34 Financing of Public-Private Partnership Projects in the Energy Sector ..................... 86

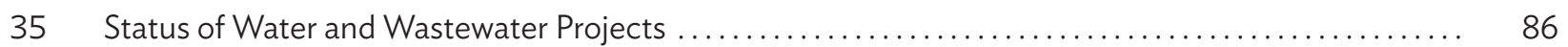

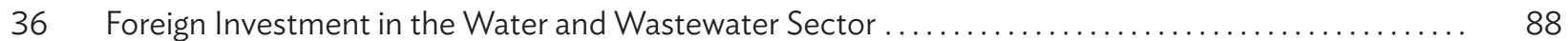

37 Financing of Public-Private Partnership Projects in the Water and Wastewater Sector............ 92

38 Status of Information and Communication Technology Projects ......................... 93

39 Foreign Investment in the Information and Communication Technology Sector ................... 94

40 Financing of Public-Private Partnership Projects in the Information and. ....................... 98 Communication Technology Sector

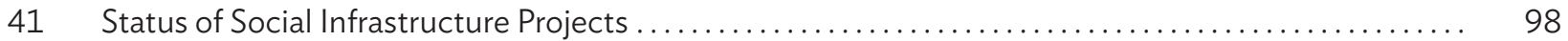

42 Foreign Investment in the Social Infrastructure Sector $\ldots \ldots \ldots \ldots \ldots \ldots \ldots \ldots \ldots \ldots \ldots \ldots \ldots \ldots$

43 Financing of Public-Private Partnership Projects in the Social Infrastructure Sector ............. 104

44 Foreign Investment in the Other Infrastructure Sector.................................... 105

45 Financing of Public-Private Partnership Projects in the Municipal Solid Waste Sector ............ 110

46 Public Financial Management Profile of Pakistan's Subnational Governments . . . . . . . . . . . . . 111

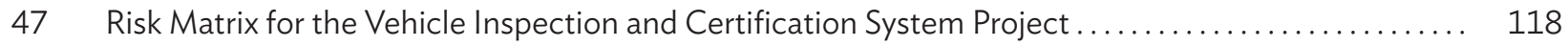

A1.1 Overview ................................................................... 119

A1.2 National Public-Private Partnership Landscape ................................... 120

A1.3 Sector-Specific Public-Private Partnership Landscape ............................... 133

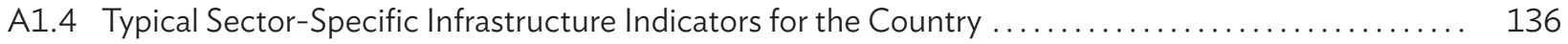

A1.5 Local Government Public-Private Partnership Landscape . . . . . . . . . . . . . . . . . . . . . . . . . 138

A1.6 Critical Macroeconomic and Infrastructure Sector Indicators for the Country................. 141

A2 Macroeconomic and Infrastructure Sector Indicators of Pakistan .......................... 149

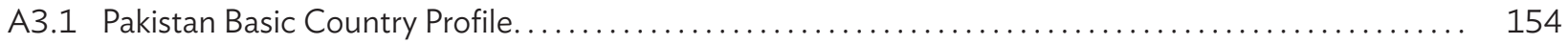

A3.2 Scores on Doing Business in Pakistan, by Categories and Subcategories...................... 155

A4.1 Public Expenditure and Financial Accountability Assessment of Pakistan's . . . . . . . . . . . . . . . . 157 Public Financial Management System, 2012

A4.2 Budgetary Transfers from the National Government to the Subnational Governments ............ 158 


\section{Figures}

$1 \quad$ Public-Private Partnership Projects Financially Closed and Cancelled, 1990-2019 ............... 2

2 Status of Public-Private Partnership Projects across Sectors . . . . . . . . . . . . . . . . . . . . . . . 3

3 Investments in Public-Private Partnerships by Sector, 1990-2019 ......................... 3

$4 \quad$ Various Modes of Procuring Public-Private Partnership Projects, 1990-2019................... 4

$5 \quad$ Public-Private Partnership Projects under Preparation and Procurement, 2019 ................... 5

6 Public-Private Partnership Projects with Government Support, 1990-2019 ................... 6

7 Payment Mechanism for Public-Private Partnership Projects, 1990-2019 . . . . . . . . . . . . . . . . 6

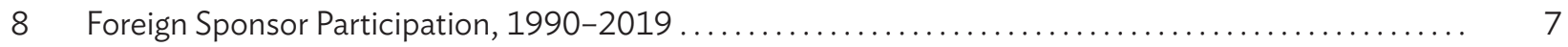

9 Public-Private Partnership Life Cycle and Processes in Pakistan .............................. 19

10 Public-Private Partnership Road Projects under Preparation and Procurement ................... 46

11 Modes of Procurement for Public-Private Partnership Roads . . . . . . . . . . . . . . . . . . . . . . . 48

12 Public-Private Partnership Road Projects Reaching Financial Closure $\ldots \ldots \ldots \ldots \ldots \ldots \ldots \ldots \ldots \ldots \quad 48$

13 Public-Private Partnership Road Projects with Foreign Sponsor Participation . . . . . . . . . . . . . . . . . . 49

14 Government Support to Public-Private Partnership Road Projects . . . . . . . . . . . . . . . . . . . . . . . . . . . . . 49

15 Payment Mechanisms for Public-Private Partnership Road Projects .......................... 50

16 Public-Private Partnership Railway Projects under Preparation and Procurement ................. 56

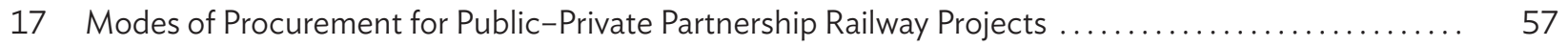

18 Public-Private Partnership Railway Projects Reaching Financial Closure . . . . . . . . . . . . . . . . . 58

19 Public-Private Partnership Railway Projects with Foreign Sponsor Participation. . . . . . . . . . . . . . . 58

20 Government Support to Public-Private Partnership Railway Projects .......................... 59

21 Payment Mechanism for Public-Private Partnership Railway Projects. . . . . . . . . . . . . . . . . . . 59

22 Public-Private Partnership Port Projects under Preparation and Procurement $\ldots \ldots \ldots \ldots \ldots \ldots \ldots .63$

23 Modes of Procurement for Public-Private Partnership Port Projects . . . . . . . . . . . . . . . . . . . . . . . . . . 64

24 Public-Private Partnership Port Projects Reaching Financial Closure . . . . . . . . . . . . . . . . . . . . . . . . 64

25 Public-Private Partnership Port Projects with Foreign Sponsor Participation . . . . . . . . . . . . . . . . 65

26 Government Support to Public-Private Partnership Port Projects . . . . . . . . . . . . . . . . . . . . . 65

27 Payment Mechanism for Public-Private Partnership Port Projects . . . . . . . . . . . . . . . . . . . . . . 66

28 Public-Private Partnership Airport Projects under Preparation and Procurement ................ 71

29 Modes of Procurement for Public-Private Partnership Airport Projects . . . . . . . . . . . . . . . . . . 72

30 Public-Private Partnership Airport Projects Reaching Financial Closure $\ldots \ldots \ldots \ldots \ldots \ldots \ldots \ldots \ldots \quad 72$

31 Public-Private Partnership Airport Projects with Foreign Sponsor Participation . . . . . . . . . . . . . . . 73

32 Government Support to Public-Private Partnership Airport Projects . . . . . . . . . . . . . . . . . . 73 
33 Payment Mechanisms for Public-Private Partnership Airport Projects $\ldots \ldots \ldots \ldots \ldots \ldots \ldots \ldots \ldots \ldots \ldots$

34 Public-Private Partnership Energy Projects under Preparation and Procurement................. 82

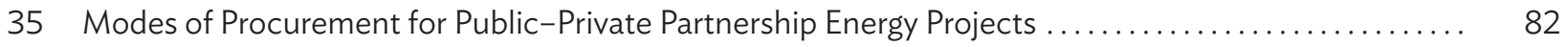

36 Independent Power Producers, Public-Private Partnership Energy Projects. . . . . . . . . . . . . . . . 83 Reaching Financial Closure

37 Independent Power Producers, Public-Private Partnership Energy Projects . . . . . . . . . . . . . . . . . . 83 with Foreign Sponsor Participation

38 Government Support to Independent Power Producers and Public-Private $\ldots \ldots \ldots \ldots \ldots \ldots \ldots \ldots$ Partnership Energy Projects

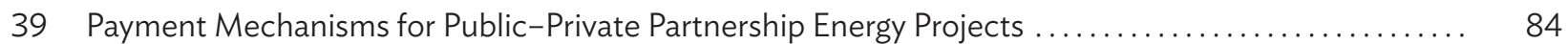

40 Public-Private Partnership Water and Wastewater Projects under Preparation and Procurement ..... 89

41 Modes of Procurement for Public-Private Partnership Water and Wastewater Projects . . . . . . . . . . . 90

42 Public-Private Partnership Water and Wastewater Projects Reaching Financial Closure ............. 90

43 Public-Private Partnership Water and Wastewater Projects with Foreign Sponsor Participation ....... 91

44 Government Support for Public-Private Partnership Water and Wastewater Projects.............. 91

45 Payment Mechanisms for Public-Private Partnership Water and Wastewater Projects .............. 92

46 Public-Private Partnership Information and Communication Technology Projects................. 95 under Preparation and Procurement

47 Modes of Procurement for Public-Private Partnership Information. . . . . . . . . . . . . . . . . . . . . . . . 95 and Communication Technology Projects

48 Public-Private Partnership Information and Communication Technology Projects ................ 96 Reaching Financial Closure

49 Public-Private Partnership Information and Communication Technology Projects.................. 96 with Foreign Sponsor Participation

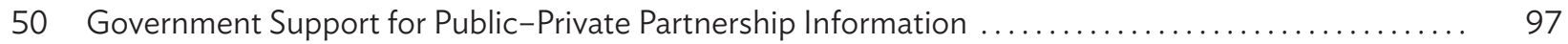
and Communication Technology Projects

51 Payment Mechanisms for Public-Private Partnership Information $\ldots \ldots \ldots \ldots \ldots \ldots \ldots \ldots \ldots \ldots \ldots . \ldots 7$ and Communication Technology Projects

52 Public-Private Partnership Social Infrastructure Projects under Preparation and Procurement . . . . . . 101

53 Modes of Procurement for Public-Private Partnership Social Infrastructure Projects. . . . . . . . . . . . 102

54 Public-Private Partnership Social Infrastructure Projects Reaching Financial Closure .............. 102

55 Public-Private Partnership Social Infrastructure Projects with Foreign Sponsor Participation . . . . . . . 103

56 Government Support to Public-Private Partnership Social Infrastructure Projects . . . . . . . . . . . . . 103

57 Payment Mechanisms for Public-Private Partnership Social Infrastructure Projects................. 104

58 Public-Private Partnership Municipal Solid Waste Projects under Preparation and Procurement . . . . . 107

59 Modes of Procurement for Public-Private Partnership Municipal Solid Waste Projects. . . . . . . . . . . 107

60 Public-Private Partnership Municipal Solid Waste Projects Reaching Financial Closure ............. 108

61 Public-Private Partnership Municipal Solid Waste Projects with Foreign Sponsor Participation. ....... 108 
62 Government Support to Public-Private Partnership Municipal Solid Waste Projects................ 109

63 Payment Mechanisms for Public-Private Partnership Municipal Solid Waste Projects .............. 109

A3.1 Rankings on Doing Business in Pakistan by Categories, 2020 . . . . . . . . . . . . . . . . . . . . . . . 154

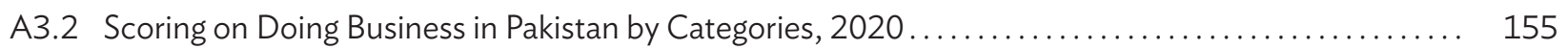

Box

Assessment of Pakistan's Public Financial Management and Accountability System.... 


\section{Foreword}

We are pleased to present the Public-Private Partnership Monitor, a detailed review of the current state of publicprivate partnership (PPP) enabling environment in selected countries in Asia and the Pacific.

Availability of adequate infrastructure is a measure of a country's ability to sustain its economic growth. For economies across Asia and the Pacific, provision of basic infrastructure services, including water, health, energy, transportation, and communications, is an important public sector activity. As demand for infrastructure has increased faster than government budgets, the public sector has increasingly considered partnership with the private sector as an alternate modality for financing infrastructure.

The Asian Development Bank (ADB) estimates that Asia and the Pacific must spend \$1.7 trillion a year on infrastructure until 2030 to maintain growth, meet social needs, and respond to the effects of climate change. That amount is expected to go up. The traditional sources of finance for infrastructure-the government's budgetary allocations - have not been enough to meet the demand. Prior to the coronavirus disease (COVID-19) pandemic, ADB estimated an annual infrastructure gap of $\$ 204$ billion to be filled through private sector investment. That amount is also now expected to increase.

For the private sector, investment in infrastructure, whether through PPPs or otherwise, represents an investment avenue competing with various other investment options available. In order to compete, and to crowd in private capital into infrastructure, governments need to provide a conducive environment to adequately establish and protect the rights of the private sector, and the necessary support to ensure every asset brought to market provides returns that are commensurate with the risks.

The PPP Monitor provides the investor community with business intelligence on the enabling environment, policies, priority sectors, and deals to facilitate informed investment decisions. For ADB developing member countries (DMCs), the PPP Monitor serves as a diagnostic tool to identify gaps in their legal, regulatory, and institutional framework. ADB and other international development agencies can also benefit from the PPP Monitor as it could be useful in initiating dialogues to assess a country's readiness to tap PPPs as a means to develop and sustain its infrastructure.

Building on the success of the previous editions of the PPP Monitor, the new PPP Monitor is now being brought online to widen its reach. More countries will be continually added in the PPP Monitor and it is expected to become a primary knowledge base for assessing a country's PPP environment for the government and the business community. The PPP Monitor features an interactive online version which allows users to compare and contrast the key PPP parameters and features across the DMCs. The online version of the PPP Monitor may be accessed at http://www.pppmonitor.adb.org. 
The PPP Monitor has been upgraded to provide a 'one-stop' information source, derived from a consolidation of (i) the previous PPP Monitor; (ii) leading PPP databases of multilateral development banks like the World Bank and the IFC and organizations like EIU (Infrascope), and GI Hub (InfraCompass); (iii) reports of a country's PPP unit; (iv) a country's legal framework; and (v) consultations with leading technical experts and legal firms as well as financial institutions.

The PPP Monitor includes more than 500 qualitative and quantitative indicators to profile the national PPP environment, the sector-specific PPP landscape (for eight identified infrastructure sectors), and the PPP landscape for local government projects. The COVID-19 pandemic has pushed social infrastructure into the forefront of policy and planning; hence, where possible, this PPP Monitor takes a bigger focus on social and municipal aspects like health, education, and affordable housing.

The PPP market in most of ADB DMCs is still at an emerging/developing stage, and continuous regulatory reforms and institutional strengthening are required to facilitate further private sector investment in infrastructure and to create a sustainable pipeline of bankable projects. Through the PPP Monitor, ADB continues to provide support for DMCs in addressing various infrastructure and PPP-related challenges, in developing sustainable infrastructure projects, and in delivering efficient and effective public services through PPPs. ADB also helps DMCs improve their investment climates, formulate sound market regulations, and build robust legal and institutional frameworks to encourage private sector participation in infrastructure through PPPs.

We hope that this PPP Monitor will pave the way for continued dialogue between the public and private sectors and stimulate the adoption of PPPs in the Asia and Pacific region.

Yoji Morishita

Head, Office of Public-Private Partnerships

Asian Development Bank 


\section{Acknowledgments}

The Public-Private Partnership Monitor: Pakistan was prepared by the Asian Development Bank (ADB) Office of Public-Private Partnership (OPPP), in close coordination with the Pakistan Resident Mission.

This effort has been led by Sanjay Grover, public-private partnership (PPP) specialist in the PPP Thematic Group Secretariat, who developed, refined, and streamlined the analytical framework for capturing the national, subnational, and sectoral PPP-related landscape that has been utilized in this document.

Yoji Morishita, head of OPPP, and Srinivas Sampath, chief of the PPP Thematic Group, have provided helpful guidance and unfailing support during the development of this PPP Monitor.

The PPP Monitor uses data published by the governments of ADB's developing member countries - on their official websites and in reports, publications, laws, and regulations - as well as data published by other multilateral development agencies and included in industry publications and databases such as those of the World Bank, Organisation for Economic Co-operation and Development, World Economic Forum, International Monetary Fund, Inframation Group, IJGlobal, Economist Intelligence Unit (Infrascope Index), Global Infrastructure Hub, TheGlobalEconomy.com, Bloomberg, S\&P Global, Trading Economics, and the PPP Knowledge Lab.

ADB has partnered with CRISIL Infrastructure Advisory and Panapps Inc. CRISIL Infrastructure Advisory, led by Abhijeet Giri, shared its expertise and provided inputs in developing the PPP Monitor for Pakistan, while Panapps Inc. has published this report online.

Ricardo McKImon, Jezreel Pabia Uy, and Carmelia Godoy have very capably led the management and coordination with the numerous contributors to this report. The contributions and review by Mohammed Azim Hashimi, Sheharyar Chughtai from OPPP, and by the Pakistan Resident Mission, led by Sana Masood, Salman M. Mian, Zainab Hamid, and Zayed Maud were instrumental in the quality control of this document.

Several others provided help and support-Cyrel San Gabriel edited the report, Asiatype Inc. performed the typesetting, Joy Quitazol-Gonzalez proofread the page proofs, and Claudette Rodrigo designed the cover. April-Marie Gallega and Ayun Sundari of the Knowledge Support Division of ADB's Department of Communications provided guidance and assistance in the publication process. 


\section{Definition of Terms}

\begin{tabular}{|c|c|}
\hline Term & Definition \\
\hline $\begin{array}{l}\text { Public-private } \\
\text { partnership } \\
\text { (PPP) }\end{array}$ & $\begin{array}{l}\text { Contractual arrangement between public (national, state, provincial, or local) and private entities } \\
\text { through which the skills, assets, and/or financial resources of each of the public and private sectors are } \\
\text { allocated in a complementary manner, thereby sharing the risks and rewards, to seek to provide optimal } \\
\text { service delivery and good value to citizens. In a PPP, the public sector retains the ultimate responsibility } \\
\text { for service delivery, although the private sector provides the service for an extended time. } \\
\text { Within Asian Development Bank operations, all contracts such as performance-based contracts } \\
\text { (management and service contracts), lease-operate-transfer, build-own-operate-transfer, design- } \\
\text { build-finance-operate, variants, and concessions are considered as various forms of PPP. } \\
\text { Excluded are } \\
\text { contracts involving turnkey design and construction as part of public procurement (engineering, } \\
\text { procurement, and construction contracts); } \\
\text { simple service contracts that are not linked to performance standards (those that are more } \\
\text { aligned with outsourcing to private contractor staff to operate public assets); } \\
\text { construction contracts with extended warranties and/or maintenance provisions of, for example, } \\
\text { up to } 5 \text { years post completion (wherein performance risk-sharing is minimal as the assets are } \\
\text { new and need only basic maintenance); and } \\
\text { all privatization and divestures. }\end{array}$ \\
\hline $\begin{array}{l}\text { Affermage or lease } \\
\text { contracts }\end{array}$ & $\begin{array}{l}\text { Under a lease contract, the private sector developer is responsible for the service in its entirety and } \\
\text { undertakes obligations relating to quality and service standards. Except for new and replacement } \\
\text { investments, which remain the responsibility of the government contracting agency, the operator } \\
\text { provides the service at his expense and risk. The duration of the leasing contract is typically } 10 \\
\text { years and may be renewed up to } 20 \text { years. Responsibility for service provision is transferred from } \\
\text { the public sector to the private sector and the financial risk for operation and maintenance is borne } \\
\text { entirely by the private sector operator. In particular, the operator is responsible for losses and for } \\
\text { unpaid consumers' debts. Leases do not involve any sale of assets to the private sector. }\end{array}$ \\
\hline $\begin{array}{l}\text { Availability-/ } \\
\text { performance- } \\
\text { based payments }\end{array}$ & $\begin{array}{l}\text { Method of investment recovery in PPP projects, when payments to the private party are made } \\
\text { by the government contracting agency over the lifetime of a PPP contract in return for making } \\
\text { infrastructure or services available for use at acceptable and contractually agreed performance } \\
\text { standards. }\end{array}$ \\
\hline $\begin{array}{l}\text { Best and final offer } \\
\text { (BAFO) }\end{array}$ & $\begin{array}{l}\text { An incentive mechanism provided by the government contracting agency to the private sector } \\
\text { developer initiating a PPP project through the unsolicited proposal route (USP proponent) to be } \\
\text { automatically shortlisted for the final bidding round and provide its best and final offer to match the } \\
\text { other bidders' best offer. }\end{array}$ \\
\hline $\begin{array}{l}\text { Build-lease- } \\
\text { transfer }\end{array}$ & $\begin{array}{l}\text { A PPP type whereby a private sector developer is authorized to finance and construct an infrastructure } \\
\text { or development facility, and upon its completion hands it over to the government contracting agency } \\
\text { on a lease arrangement for a fixed period after which ownership of the facility is automatically } \\
\text { transferred to the government contracting agency. }\end{array}$ \\
\hline
\end{tabular}


continued from previous page

\section{Term}

Build-own-operate

(

Build-operatetransfer

Build-transfer

Commercial close

id

Competitive

bidding

\begin{tabular}{|l|l}
\hline Concession & co \\
& A \\
& resp \\
& coll \\
& p \\
& resp \\
& the \\
& the \\
&
\end{tabular}

Currency
conversion swap
fee

Direct agreement

Direct negotiations

Dispute resolution
Definition

A PPP type whereby a private sector developer is authorized to finance, construct, own, operate, and maintain an infrastructure or development facility from which the private sector developer is allowed to recover its total investment, operating and maintenance costs plus a reasonable return thereon by collecting tolls, fees, rentals or other charges from facility users. Under this PPP type, the private sector developer which owns the assets of the facility may assign its operation and maintenance to a facility operator.

Build-operate-transfer (BOT) and similar arrangements are a specialized concession in which a private firm or consortium finances and develops a new infrastructure project or a major component according to performance standards set by the government.

Under BOTs, the private sector developer provides the capital required to build a new facility. Importantly, the private operator now owns the assets for a period set by contract-sufficient to give the developer time to recover investment costs through user charges.

A PPP type under which the private sector developer undertakes the financing and construction of a given infrastructure or development facility, and after its completion hands it over to the government contracting agency, which pays the private sector developer on an agreed schedule its total investments expended on the project, plus a reasonable rate of return thereon. This arrangement may be employed in the construction of any infrastructure or development project, including critical facilities which, for security or strategic reasons, must be operated directly by the government contracting agency.

Indicates the signing of the PPP contract between the government contract agency and the identified private sector developer. Usually occurs after the terms and conditions of the draft PPP contract are negotiated and agreed between the government contracting agency and the identified private sector developer.

A process under which the bidders submit information detailing their qualifications and detailed technical and financial proposals, which are evaluated according to defined criteria-often in a multi-stage process - to select a preferred bidder. Competitive bidding may also include competitive negotiations and license schemes.

A PPP type which makes the concessionaire (established by the selected private sector developer) responsible for the full delivery of services in a specified area, including operation, maintenance, collection, management, and construction and rehabilitation of the system. Importantly, the private sector developer is responsible for all capital investment. Although the concessionaire is responsible for providing the assets, such assets are publicly owned even during the concession period. The public sector is responsible for establishing performance standards and ensuring that the concessionaire meets them. In essence, the public sector's role shifts from being the service provider to regulating the price and quality of service.

A premium which is paid by the borrower to settle on a swap in which the parties sell currencies to each other subject to an agreement to repurchase the same currency in the same amount, at the same exchange rate, and on a fixed date in the future.

An agreement normally made between the concessionaire (established by the private sector developer), the government contracting agency, and the lenders. The agreement usually gives the lenders step-in rights to take over the operation of the key PPP contracts.

A type of PPP procurement under which the PPP contract is awarded on the basis of a direct agreement with a private sector developer without going through the competitive bidding process.

A process to resolve any dispute between the government contracting agency and the private sector developer as agreed in the PPP contract. The possible dispute resolution mechanisms in a PPP contract could include resolution through

- discussion between both parties,

- dispute resolution board,

- expert determination,

- mediation or conciliation, or

- arbitration. 
continued from previous page

\begin{tabular}{|c|c|}
\hline Term & Definition \\
\hline $\begin{array}{l}\text { Environmental } \\
\text { impact assessment }\end{array}$ & $\begin{array}{l}\text { A process of evaluating the likely environmental impacts of a proposed project or development, } \\
\text { taking into account interrelated socioeconomic, cultural, and human health impacts, both beneficial } \\
\text { and adverse. }\end{array}$ \\
\hline Feed-in tariff (FIT) & $\begin{array}{l}\text { A policy mechanism designed to accelerate investment in renewable energy technologies by } \\
\text { offering long-term purchase agreements for the sale of renewable energy electricity. }\end{array}$ \\
\hline Financial close & $\begin{array}{l}\text { An event whereby (i) a legally binding commitment of equity holders and/or debt financiers exists } \\
\text { to provide or mobilize funding for the full cost of the project, and (ii) the conditions for funding } \\
\text { have been met and the first tranche of funding is mobilized. If this information is not available, } \\
\text { construction start date is used as an estimated financial closure date. }\end{array}$ \\
\hline $\begin{array}{l}\text { Financial } \\
\text { equilibrium }\end{array}$ & $\begin{array}{l}\text { A mechanism in a PPP agreement for dealing with changes, when changes in specified conditions } \\
\text { and circumstances trigger compensating changes to the terms of the agreement. Some civil law } \\
\text { jurisdictions emphasize economic or financial equilibrium provisions that entitle a partner to } \\
\text { changes in the key financial terms of the contract to compensate for certain types of exogenous } \\
\text { events that may otherwise impact returns. The partner is protected as the economic balance of the } \\
\text { contract must be maintained and adequate compensation paid for damages suffered. Unexpected } \\
\text { changes that merit financial equilibrium may arise from force majeure (major natural disasters or } \\
\text { civil disturbances), government action, and unforeseen changes in economic conditions. }\end{array}$ \\
\hline Force majeure & $\begin{array}{l}\text { An event that is reasonably beyond the reasonable control of the affected party as a result of } \\
\text { which such party's performance of its obligations under the PPP contract is prevented or rendered } \\
\text { impossible. Force majeure events may include } \\
\text { - war, civil war, armed conflict or terrorism; } \\
\text { - nuclear, chemical, or biological contamination unless the source or the cause of the } \\
\text { contamination is the result of the actions of or breach by the concessionaire or its } \\
\text { subcontractors; } \\
\text { - pressure waves caused by devices travelling at supersonic speeds, which directly causes either } \\
\text { party (the "Affected Party") to be unable to comply with all or a material part of its obligations } \\
\text { under the contract; or } \\
\text { any other similar events that are beyond reasonable control of the affected party, and prevent or } \\
\text { render impossible the performance by such party of its obligations under the PPP contract. }\end{array}$ \\
\hline $\begin{array}{l}\text { Government } \\
\text { contracting agency }\end{array}$ & $\begin{array}{l}\text { The ministry, department, or agency that enters into a PPP contract with the private sector and is } \\
\text { responsible for ensuring that the relevant public assets or services are provided. }\end{array}$ \\
\hline $\begin{array}{l}\text { Government } \\
\text { guarantee }\end{array}$ & $\begin{array}{l}\text { Agreements under which the government agrees to bear some or all risks of a PPP project. It is a } \\
\text { secondary obligation which legally binds the government to take on an obligation if a specified event } \\
\text { occurs. A government guarantee constitutes a contingent liability, for which there is uncertainty as } \\
\text { to whether the government may be required to make payments, and if so, how much and when it } \\
\text { will be required to pay. } \\
\text { In practice, government guarantees are used when debt providers are unwilling to lend to a } \\
\text { private party in a PPP because of concerns over credit risk and potential loan losses. Government } \\
\text { guarantees can also be used to benefit equity investors in a PPP company when they require } \\
\text { protection against the investment risks they bear. }\end{array}$ \\
\hline $\begin{array}{l}\text { Government pay } \\
\text { (Offtake) }\end{array}$ & $\begin{array}{l}\text { Represents the payment made by the government contracting agency to the concessionaire } \\
\text { (established by the private sector developer) for the infrastructure assets provided and services } \\
\text { delivered through a PPP project. These payments could be } \\
\text { - usage-based-for example, shadow tolls or output-based subsidies; } \\
\text { - based on availability-that is, conditional on the availability of an asset or service to the specified } \\
\text { - quality; and }\end{array}$ \\
\hline
\end{tabular}


continued from previous page

\begin{tabular}{|c|c|}
\hline Term & Definition \\
\hline $\begin{array}{l}\text { Gross-cost } \\
\text { contract }\end{array}$ & $\begin{array}{l}\text { A type of PPP contract arrangement in the railway sector under which all revenues (from fares and } \\
\text { other sources) are transferred to the government contracting agency, and the risks absorbed by the } \\
\text { developer are confined to those associated with the cost of operations. }\end{array}$ \\
\hline $\begin{array}{l}\text { Hybrid } \\
\text { arrangement }\end{array}$ & $\begin{array}{l}\text { A method of investment recovery in PPP projects when payments to the private party are made } \\
\text { as a combination of user charges and availability payments over the lifetime of a PPP contract, in } \\
\text { return for making infrastructure or services available for use at acceptable and contractually agreed } \\
\text { performance standards. }\end{array}$ \\
\hline $\begin{array}{l}\text { Independent power } \\
\text { producer (IPP) } \\
\text { scheme }\end{array}$ & $\begin{array}{l}\text { A scheme whereby a producer of electrical energy, which is not a public utility, makes electric } \\
\text { energy available for sale to utilities or the general public. } \\
\text { A scheme whereby a producer of electrical energy, which is a private entity, owns and/or operates } \\
\text { facilities to generate electricity and then sells it to a utility, central government buyer, or end users. } \\
\text { The IPP invests in generation technologies and recovers their cost from the sale of the electricity. }\end{array}$ \\
\hline $\begin{array}{l}\text { Institutional } \\
\text { arbitration }\end{array}$ & $\begin{array}{l}\text { An arbitration process in which a specialized institution intervenes and takes on the role of } \\
\text { administering the arbitration process between the government contracting agency and the private } \\
\text { sector developer for a PPP project-related dispute. This institution would have its own set of rules } \\
\text { which would provide a framework for the arbitration, and its own form of administration to assist in } \\
\text { the process. }\end{array}$ \\
\hline $\begin{array}{l}\text { Interest rate } \\
\text { swap fee }\end{array}$ & $\begin{array}{l}\text { A premium paid by the borrower for a hedging contract to convert a floating interest rate into a } \\
\text { fixed rate. The two parties agree to exchange interest rate payments based on a notional principal } \\
\text { amount, with typically one paying a fixed rate and the other generally paying a floating rate. }\end{array}$ \\
\hline Joint venture & $\begin{array}{l}\text { An alternative to full privatization in which the infrastructure is co-owned and operated by the } \\
\text { public sector and private operators. Under a joint venture, the public and private sector partners } \\
\text { can either form a new company or assume joint ownership of an existing company through a sale of } \\
\text { shares to one or several private investors. The company may also be listed on the stock exchange. }\end{array}$ \\
\hline $\begin{array}{l}\text { Lender's step-in } \\
\text { rights }\end{array}$ & $\begin{array}{l}\text { Lender's rights in project-financed arrangements to "step in" to the project company's position } \\
\text { in the contract to take control of the infrastructure project where the project company is not } \\
\text { performing. }\end{array}$ \\
\hline $\begin{array}{l}\text { Management } \\
\text { contract }\end{array}$ & $\begin{array}{l}\text { A PPP type which expands the services to be contracted out to include some or all of the } \\
\text { management and operation of the public service (i.e., utility, hospital, port authority). Although } \\
\text { ultimate obligation for service provision remains in the public sector, daily management control and } \\
\text { authority is assigned to the private partner or contractor. In most cases, the private partner provides } \\
\text { working capital but no financing for investment. }\end{array}$ \\
\hline $\begin{array}{l}\text { Material adverse } \\
\text { government action }\end{array}$ & $\begin{array}{l}\text { An action by the government which directly and materially affects the private party of a PPP project } \\
\text { in performing its obligations under the relevant PPP contract, and which would reasonably be } \\
\text { expected to result in a material adverse effect. }\end{array}$ \\
\hline Net-cost contract & $\begin{array}{l}\text { A type of PPP contract arrangement in the railway sector under which all revenues (from fares and } \\
\text { other sources) are retained by the developer, and traffic and revenue risks are absorbed either fully } \\
\text { or as per a contractually agreed portion. }\end{array}$ \\
\hline $\begin{array}{l}\text { Nominal interest } \\
\text { rate }\end{array}$ & $\begin{array}{l}\text { The nominal interest rate is the interest rate applicable to a borrowing before taking inflation } \\
\text { adjustment into account. In certain cases, nominal interest rate also refers to the advertised or stated } \\
\text { interest rate on a borrowing, without taking into account any fees or compounding of interest. } \\
\text { Nominal interest rate = Real interest rate + Inflation rate }\end{array}$ \\
\hline $\begin{array}{l}\text { Nonrecourse/ } \\
\text { limited recourse } \\
\text { project financing }\end{array}$ & $\begin{array}{l}\text { The financing of the development or exploitation of a right, natural resource, or other assets where } \\
\text { the bulk of the financing is to be provided by way of debt, and is to be repaid principally out of the } \\
\text { assets being financed and their revenues. }\end{array}$ \\
\hline
\end{tabular}


continued from previous page

\begin{tabular}{|c|c|}
\hline Term & Definition \\
\hline $\begin{array}{l}\text { Output-based aid } \\
\text { (OBA) }\end{array}$ & $\begin{array}{l}\text { Refers to development aid strategies that link the delivery of public services in developing countries } \\
\text { to targeted performance-related subsidies. OBA provides a way in which international financial } \\
\text { institutions can directly structure their financing to benefit poor people, even when the service } \\
\text { provider is a private company. OBA is the use of explicit, performance-based subsidies funded by } \\
\text { the donor agencies to complement or replace user fees. It involves the contracting out of basic } \\
\text { service provision to a third party-such as private companies, nongovernment organizations, } \\
\text { community-based organizations, and even public service providers-with subsidy payment tied to } \\
\text { the delivery of specified outputs. This means that targeted and valuable subsidies to disadvantaged } \\
\text { populations are funded through donor funds. The private partner, meanwhile, can only recover this } \\
\text { funding by achieving specific performance outcomes. }\end{array}$ \\
\hline $\begin{array}{l}\text { Project bond } \\
\text { financing }\end{array}$ & An alternative source of financing infrastructure project by placing bonds. \\
\hline $\begin{array}{l}\text { Project } \\
\text { development }\end{array}$ & $\begin{array}{l}\text { Indicates the stage of the PPP project life cycle including PPP project identification, preparation, } \\
\text { structuring, and procurement up to commercial close between the government contracting agency } \\
\text { and the private sector developer. }\end{array}$ \\
\hline $\begin{array}{l}\text { Project } \\
\text { development fund } \\
\text { (PDF) }\end{array}$ & $\begin{array}{l}\text { A fund dedicated to reimbursing the cost of feasibility studies, transaction advisers, and other costs } \\
\text { of project development, to encourage contracting agencies to use high-quality transaction advisers } \\
\text { and best practice. PDFs provide the specialized resources needed to conduct studies, to design and } \\
\text { structure a PPP, and then to procure the PPP. }\end{array}$ \\
\hline Real interest rate & $\begin{array}{l}\text { The real interest rate is the interest rate applicable to a borrowing that takes inflation rate into } \\
\text { account. } \\
\text { Real interest rate = Nominal interest rate }- \text { Inflation rate }\end{array}$ \\
\hline $\begin{array}{l}\text { Regulatory } \\
\text { framework }\end{array}$ & $\begin{array}{l}\text { A framework encompassing all laws, regulations, policies, binding guidelines or instructions, other } \\
\text { legal texts of general application, judicial decisions, and administrative rulings governing or setting } \\
\text { precedent in connection with PPPs. In this context, the term "policies" refers to other government- } \\
\text { issued documents, which are binding on all stakeholders, are enforced in a manner similar to laws } \\
\text { and regulations, and provide detailed instructions for the implementation of PPPs. }\end{array}$ \\
\hline $\begin{array}{l}\text { Rehabilitate- } \\
\text { operate-transfer }\end{array}$ & $\begin{array}{l}\text { A PPP type whereby an existing facility is handed over to the private sector developer to refurbish, } \\
\text { operate and maintain for a franchise period, at the expiry of which the legal title to the facility is } \\
\text { turned over to the government contracting agency. }\end{array}$ \\
\hline $\begin{array}{l}\text { Risk allocation } \\
\text { matrix }\end{array}$ & $\begin{array}{l}\text { Matrix indicating the allocation of the consequences of each risk to one of the parties in the PPP } \\
\text { contract, or agreeing to deal with the risk through a specified mechanism which may involve sharing } \\
\text { the risk. }\end{array}$ \\
\hline Service contract & $\begin{array}{l}\text { A PPP type under which the government contracting agency hires a private company or entity to } \\
\text { carry out one or more specified tasks or services for a period, typically } 1-3 \text { years. The government } \\
\text { contracting agency remains the primary provider of the infrastructure service and contracts out } \\
\text { only portions of its operation to the private partner. The private partner must perform the service at } \\
\text { the agreed cost and must typically meet performance standards set by the government contracting } \\
\text { agency. Government contracting agencies generally use competitive bidding procedures to award } \\
\text { service contracts, which tend to work well given the limited period and narrowly defined nature of } \\
\text { these contracts. }\end{array}$ \\
\hline $\begin{array}{l}\text { Social impact } \\
\text { assessment }\end{array}$ & $\begin{array}{l}\text { Includes the processes of analysing, monitoring, and managing the intended and unintended social } \\
\text { consequences - both positive and negative-of planned interventions (policies, programs, plans, } \\
\text { projects) and any social change processes invoked by those interventions. Its primary purpose is to } \\
\text { bring about a more sustainable and equitable biophysical and human environment. }\end{array}$ \\
\hline $\begin{array}{l}\text { Social } \\
\text { infrastructure }\end{array}$ & Covers social services, including hospitals, schools and universities, prisons, housing, and courts. \\
\hline
\end{tabular}


continued from previous page

\begin{tabular}{|l|l|}
\hline $\begin{array}{l}\text { Term } \\
\text { State-owned } \\
\text { enterprise (SOE) }\end{array}$ & $\begin{array}{l}\text { A company or enterprise owned by the government or in which the government has a controlling } \\
\text { stake. }\end{array}$ \\
\hline Swiss challenge & $\begin{array}{l}\text { A process in public procurement when a government contracting agency that has received an } \\
\text { unsolicited bid for a project publishes details of the bid and invites third parties to match or exceed } \\
\text { it. }\end{array}$ \\
\hline Tax holiday & $\begin{array}{l}\text { A government incentive program that offers tax reduction or elimination to projects and/ or } \\
\text { businesses. In the context of a PPP project, tax holidays are provided to exempt the concessionaire } \\
\text { from making any tax payments during the initial demand ramp up period to make the project } \\
\text { financially viable. }\end{array}$ \\
\hline Unsolicited bid & $\begin{array}{l}\text { A proposal made by a private party to undertake a PPP project. It is submitted at the initiative of the } \\
\text { private party, rather than in response to a request from the government contracting agency. }\end{array}$ \\
\hline User charges & $\begin{array}{l}\text { A method of investment recovery in PPP projects when payments to the private party are fully } \\
\text { derived from tariffs paid by users or off-takers over the lifetime of a PPP contract, in return } \\
\text { for making infrastructure or services available for use at acceptable and contractually agreed } \\
\text { performance standards. }\end{array}$ \\
\hline Viability gap fund & $\begin{array}{l}\text { A scheme wherein the projects with low financial viability are given grants (or other financial } \\
\text { support from the government) up to a stipulated percentage of the project cost, making them } \\
\text { financially viable as PPPs. }\end{array}$ \\
\hline
\end{tabular}




\section{Abbreviations}

$\begin{array}{ll}\text { ADB } & - \text { Asian Development Bank } \\ \text { AEDB } & - \text { Alternative Energy Development Board } \\ \text { ARE } & - \text { alternative and renewable energy } \\ \text { BOO } & - \text { build-own-operate } \\ \text { BOOT } & - \text { build-own-operate-transfer } \\ \text { BOT } & - \text { build-operate-transfer } \\ \text { CGLA } & - \text { Colonization of Government Lands Act } \\ \text { EIA } & - \text { environmental impact assessment } \\ \text { EPA } & - \text { Environmental Protection Agency } \\ \text { EPPA } & - \text { energy/power purchase agreement } \\ \text { EPC } & - \text { engineering, procurement, and construction } \\ \text { GDP } & - \text { gross domestic product } \\ \text { ICT } & - \text { information and communication technology } \\ \text { IEE } & - \text { initial environmental examination } \\ \text { IPDF } & - \text { Infrastructure Project Development Facility } \\ \text { IPP } & - \text { independent power producer } \\ \text { MSW } & - \text { municipal solid waste } \\ \text { NEPRA } & - \text { National Electric Power Regulatory Authority } \\ \text { NHA } & - \text { National Highway Authority } \\ \text { O\&M } & - \text { operation and maintenance } \\ \text { P3A } & - \text { Public Private Partnership Authority (refers to Federal P3A) } \\ \text { PCAA } & - \text { Pakistan Civil Aviation Authority } \\ \text { PDF } & - \text { Project Development Facility } \\ \text { PEPA } & - \text { Pakistan Environmental Protection Act } \\ \text { PPA } & - \text { power purchase agreement } \\ \text { PPI } & - \text { Private Participation in Infrastructure (a World Bank database) } \\ \text { PPA } & \end{array}$


PPIB _ - Private Power and Infrastructure Board

PPP $\quad-$ public-private partnership

PPPA - Public Private Partnership Authority

PPRA - Public Procurement Regulatory Authority

PRC - - People's Republic of China

PTA - Pakistan Telecommunication Authority

RFP $\quad-$ request for proposal

SBP _ - State Bank of Pakistan

SIA _ - social impact assessment

SOP $\quad-\quad$ standard operating procedure

TPA - Transfer of Property Act

VGF $\quad$ - viability gap funding

VICS - vehicle inspection and certification system

WAPDA - Water and Power Development Authority 


\section{Guide to Understanding the Public-Private Partnership Monitor}

The Public-Private Partnership Monitor (PPP Monitor), a flagship publication of the Asian Development Bank (ADB), profiles the current state of the PPP enabling environment in ADB's developing member countries (DMCs) in Asia and the Pacific. The PPP Monitor features, for the first time, a data-driven, interactive online version which allows users to compare and contrast the key PPP parameters and features across the featured DMCs. While the featured countries are a small sample, more countries will be continually added in the PPP Monitor, which is expected to become a knowledge base for assessing a country's PPP environment for the government and the business community. The new PPP Monitor builds on the success of the first and second editions of the PPP Monitor.

The PPP Monitor provides a snapshot of the overall PPP landscape in the country. This downloadable guide also assesses more than 500 qualitative and quantitative indicators that have been structured per topic-the national PPP landscape, the sector-specific PPP landscape (for eight identified infrastructure sectors and a separate section for other sectors), and the PPP landscape for local government projects. The PPP Monitor also captures the critical macroeconomic and infrastructure sector indicators (including the Ease of Doing Business scores) from globally accepted sources.

Each of the topics and associated subtopics presented below are characterized by qualitative and quantitative indicators. Qualitative indicators take the form of a question to which "Yes," "No," "Not Applicable," or "Unavailable" answers can be given. Quantitative indicators are represented in the form of numbers, ratios, investment value, and duration.

For each of the developing member countries covered, the information and data are organized along the following topic clusters:

\section{Overview}

\begin{tabular}{|l|l|} 
Topic & Subtopics \\
\hline Overview & - Overview of the PPP legal and regulatory framework \\
- Number of PPP projects reaching financial close from 1990 till end of 2019 across sectors \\
- Total investment made in PPPs from 1990 to 2019 across sectors \\
- Features of past PPP projects including the number of PPPs procured through various modes \\
- Number of PPP projects under preparation and procurement \\
- Number of PPP projects supported by government \\
- Fayment mechanism for PPPs \\
- Major sponsors active in the infrastructure sector in the country \\
- Challenges associated with the PPP landscape in the country
\end{tabular}




\section{National Public-Private Partnership Landscape Indicators}

To profile the national PPP landscape, the indicators are grouped into three major categories: national PPP enabling framework, government support for PPP projects, and maturity of the PPP market.

\begin{tabular}{|c|c|}
\hline Topic & Subtopics \\
\hline $\begin{array}{l}\text { National PPP legal and regulatory } \\
\text { framework }\end{array}$ & $\begin{array}{l}\text { Details on the legal and regulatory framework applicable to PPPs and its evolution } \\
\text { since the introduction of PPPs in the country } \\
\text { Details on the other supporting laws and regulations governing PPPs in the country }\end{array}$ \\
\hline PPP types & $\begin{array}{l}\text { Details on the PPP types allowed to be used as per PPP legal and regulatory } \\
\text { framework. In case the PPP legal and regulatory framework doesn't specify the PPP } \\
\text { types, this section provides the details on the specific PPP types which have been } \\
\text { adopted for various PPP projects at various stages of the PPP life cycle. }\end{array}$ \\
\hline Eligible sectors & $\begin{array}{l}\text { Details on various infrastructure sectors for which projects could be procured } \\
\text { through the PPP route as per the PPP legal and regulatory framework }\end{array}$ \\
\hline $\begin{array}{l}\text { Public-private partnership } \\
\text { institutional framework }\end{array}$ & \multirow{3}{*}{$\begin{array}{l}\text { Details on the PPP institutional framework including the availability of a PPP Unit, } \\
\text { the functions of the PPP Unit, the principal public entities associated with PPPs and } \\
\text { their respective functions, and the details of the public entities responsible for PPP } \\
\text { project identification, appraisal, approval, oversight, and monitoring }\end{array}$} \\
\hline $\begin{array}{l}\text { Entities responsible for PPP project } \\
\text { identification, approval, and } \\
\text { oversight }\end{array}$ & \\
\hline $\begin{array}{l}\text { Entities responsible for PPP project } \\
\text { monitoring }\end{array}$ & \\
\hline $\begin{array}{l}\text { The public-private partnership } \\
\text { process }\end{array}$ & $\begin{array}{l}\text { Details on the various stages of the PPP process including PPP project identification, } \\
\text { preparation, structuring, procurement, and management as per the PPP legal and } \\
\text { regulatory framework in the country }\end{array}$ \\
\hline $\begin{array}{l}\text { PPP standard operating } \\
\text { procedures, tool kits, templates, } \\
\text { and model bid documents }\end{array}$ & $\begin{array}{l}\text { Details on the standard operating procedures, and standard templates or model } \\
\text { bidding documents available for PPPs (if any) } \\
\text { Details on the key clauses in a PPP Agreement based on the review of select PPP } \\
\text { Agreements already executed, and/ or the review of the PPP legal and regulatory } \\
\text { framework }\end{array}$ \\
\hline Lender's security rights & Rights of lenders including the charge of project assets \\
\hline Termination and compensation & $\begin{array}{l}\text { Definition on whether the private player is eligible for compensation in case of PPP } \\
\text { project termination due to various reasons }\end{array}$ \\
\hline Unsolicited PPP proposals & $\begin{array}{l}\text { Details on possibility of submission of unsolicited PPP proposals, and their } \\
\text { treatment, including potential advantages provided to the unsolicited PPP proposal } \\
\text { proponent at the PPP procurement stage }\end{array}$ \\
\hline $\begin{array}{l}\text { Foreign investor participation } \\
\text { restrictions }\end{array}$ & $\begin{array}{l}\text { Definition on whether there are any statutory restrictions on foreign equity } \\
\text { investments and ownership in PPP projects }\end{array}$ \\
\hline Dispute resolution & $\begin{array}{l}\text { Definition of the dispute resolution process and the mechanisms available in the } \\
\text { country }\end{array}$ \\
\hline Environmental and social issues & $\begin{array}{l}\text { Details on whether the legal and regulatory framework governing PPPs stipulates } \\
\text { a mechanism for managing the environmental and social impact of a PPP project, } \\
\text { including the potential environmental and social issues which could be caused by a } \\
\text { PPP project }\end{array}$ \\
\hline
\end{tabular}


continued from previous page

\begin{tabular}{|c|c|}
\hline Topic & Subtopics \\
\hline Land rights & $\begin{array}{l}\text { Definition of the various mechanisms through which landownership and/or land use } \\
\text { rights could be provided to the private partner in respect of the project site for a PPP } \\
\text { project } \\
\text { Details on land records and registration which could be provided to the private } \\
\text { partner }\end{array}$ \\
\hline $\begin{array}{l}\text { Government financial support for } \\
\text { PPP projects }\end{array}$ & $\begin{array}{l}\text { Details on the various mechanisms of government financial support available to } \\
\text { make PPP projects financially viable } \\
\text { Salient features of government financial support mechanisms available }\end{array}$ \\
\hline $\begin{array}{l}\text { Project development funding } \\
\text { support }\end{array}$ & $\begin{array}{l}\text { Details on the various sources through which funding could be availed for the } \\
\text { development activities (preparation, structuring, and procurement) of a PPP project } \\
\text { Details on stages of the PPP project development during which such funding could } \\
\text { be availed and utilized, including payments to transaction advisors }\end{array}$ \\
\hline PPP project statistics & $\begin{array}{l}\text { Details on the key PPP statistics in the country such as the availability of (i) a PPP } \\
\text { database showing distribution of PPP projects across sectors and across various } \\
\text { stages of the PPP life cycle, and (ii) a national PPP project pipeline and its alignment } \\
\text { with the National Infrastructure Plan for the country }\end{array}$ \\
\hline Sources of PPP financing & $\begin{array}{l}\text { Details on the sources of financing for PPP projects in the country } \\
\text { Details on typical key financing terms for various sources of financing, banks active } \\
\text { in project finance for the last } 24 \text { months, active PPP project sponsors in the country } \\
\text { for the last } 24 \text { months, availability of derivatives market, and availability of credit } \\
\text { rating agencies in the country }\end{array}$ \\
\hline
\end{tabular}

\section{Sector-Specific Public-Private Partnership Landscape Indicators}

To profile the sector-specific PPP landscape, the indicators are grouped into five major categories: (i) sectorspecific PPP contracting agencies, (ii) sector laws and regulations, (iii) sector master plan (including sectorspecific PPP pipeline), (iv) features of the past PPP projects in the sector, and (v) sector-specific challenges for PPPs. The sectors which do not appear consistently across the featured countries are covered under the 'Other Sectors' category in the sector-specific PPP landscape.

\begin{tabular}{l|l|l|} 
Topic & \multicolumn{1}{c}{ Subtopics } \\
Contracting agencies in the sector & $\begin{array}{l}\text { Details on which government agencies could act as the contracting agencies for a } \\
\text { PPP project }\end{array}$ \\
\hline Sector laws and regulations & $\begin{array}{l}\text { Details on the applicable sector laws and regulations for PPP projects, including the } \\
\text { sector regulators and their respective functions. }\end{array}$ \\
\hline $\begin{array}{l}\text { Foreign investment restrictions in } \\
\text { the sector }\end{array}$ & $\begin{array}{l}\text { Details on the maximum allowed foreign equity investment in greenfield PPP projects } \\
\text { in the sector }\end{array}$ \\
\hline Standard contracts in the sector & $\begin{array}{l}\text { Specification on whether standard contracts are available for PPP projects in the } \\
\text { sector }\end{array}$ \\
\hline
\end{tabular}


continued from previous page

\begin{tabular}{|c|c|}
\hline Topic & Subtopics \\
\hline Sector master plan & $\begin{array}{l}\text { Details on the master plan and/or road map adopted for infrastructure development } \\
\text { in the sector by the national government and the corresponding line ministry } \\
\text { Details on the pipeline of PPP projects for the sector aligned with this sector master } \\
\text { plan and/or road map } \\
\text { Details on the PPP projects under preparation and procurement in the sector }\end{array}$ \\
\hline Features of past PPP projects & $\begin{array}{l}\text { Features of the past PPP projects based on supporting indicators in terms of the } \\
\text { number and value (where applicable) of PPP projects for each supporting indicator }\end{array}$ \\
\hline Tariffs applicable to the sector & $\begin{array}{l}\text { Details on the indicative tariffs applicable in the sector based on the examples of } \\
\text { select PPP or other projects operational in the sector }\end{array}$ \\
\hline $\begin{array}{l}\text { Typical risk allocation for PPP } \\
\text { projects in the sector }\end{array}$ & $\begin{array}{l}\text { Details on the typical risk allocation between the government contracting agency and } \\
\text { the private partner based on examples of select PPP projects which have achieved } \\
\text { commercial close }\end{array}$ \\
\hline $\begin{array}{l}\text { Financing details for PPP projects in } \\
\text { the sector }\end{array}$ & $\begin{array}{l}\text { Typical financing details based on past PPP projects on the lines of the supporting } \\
\text { indicators }\end{array}$ \\
\hline $\begin{array}{l}\text { Challenges associated with PPPs in } \\
\text { the sector }\end{array}$ & $\begin{array}{l}\text { Details on the PPP-related and sector-specific challenges faced by PPP projects in } \\
\text { the sector }\end{array}$ \\
\hline $\begin{array}{l}\text { Typical sector-specific } \\
\text { infrastructure indicators for the } \\
\text { country }\end{array}$ & Details on select sector-specific infrastructure indicators for the country \\
\hline
\end{tabular}

\section{Local Government Public-Private Partnership Landscape}

To profile the PPP landscape for local government projects, the indicators are grouped into seven major categories: (i) local governance system, (ii) infrastructure development plans for local governments, (iii) sectors in which local governments can implement PPPs, (iv) revenue sources for local governments, (v) borrowings by local governments, (vi) budgetary allocation to local governments, and (vii) credit rating of local governments.

\section{Topic}

Key indicators related to local governments in the country

Local governance system

for local governments

PPP enabling framework for local governments

\section{Subtopics}

Details on the local governments using select key indicators on (i) the number and levels of local governments, (ii) the typical expenditure profile and heads, (iii) the typical revenue profile and heads, (iv) the typical debt profile and heads, and (v) grants and transfers from the higher levels of government

Details on the local governance system in the country, including the various levels of local governments; their roles, responsibilities, and functions; and the devolution of powers from the higher levels of government to the various levels of local governments

Details on the infrastructure development plans prepared by the local governments based on their capital investment projects in the pipeline, and the coverage of such infrastructure development plans

Details on the PPP enabling framework applicable to local government PPP projects, including PPP legal and regulatory framework, PPP policy framework, and PPP institutional framework 
continued from previous page

\begin{tabular}{|c|c|}
\hline Topic & Subtopics \\
\hline $\begin{array}{l}\text { Eligible sectors for PPPs for local } \\
\text { governments }\end{array}$ & $\begin{array}{l}\text { Details on the eligible sectors in which PPPs could be undertaken by the local } \\
\text { government as government contracting agency }\end{array}$ \\
\hline Revenues for local governments & Details on the typical sources of revenue for local governments \\
\hline Borrowings by local governments & $\begin{array}{l}\text { Details on the typical sources of debt financing available for local governments, the } \\
\text { purpose for which borrowed funds could be used, the terms of such borrowings, and } \\
\text { the borrowing exposure of select local governments }\end{array}$ \\
\hline $\begin{array}{l}\text { Budgetary allocation to local } \\
\text { governments }\end{array}$ & $\begin{array}{l}\text { Details on the budgetary allocations and transfers to the local governments from the } \\
\text { higher levels of government }\end{array}$ \\
\hline Credit rating of local governments & $\begin{array}{l}\text { Details on the precedence of local governments being rated by credit rating agencies } \\
\text { in the country, and the details of credit ratings obtained by select local governments } \\
\text { in the past }\end{array}$ \\
\hline $\begin{array}{l}\text { Case study on a local government } \\
\text { PPP }\end{array}$ & $\begin{array}{l}\text { A case of a PPP project undertaken by a local government in the past covering details } \\
\text { on project background, project assets, PPP structure for the project, risk allocation } \\
\text { among the parties for the project, project finance and project revenue details, and key } \\
\text { learnings from the PPP project }\end{array}$ \\
\hline
\end{tabular}

\section{Critical Macroeconomic and Infrastructure Sector Indicators}

This section captures the critical macroeconomic and infrastructure sector indicators (including the Ease of Doing Business scores) from globally accepted sources.

\section{Topic}

Critical macroeconomic and infrastructure sector indicators

Ease of Doing Business

\section{Subtopics}

Details of the select key macroeconomic and infrastructure indicators for the country

Details on the various Ease of Doing Business parameters for the country based on the World Bank's Ease of Doing Business publication

\section{Time Periods}

The research was carried out in 2020 with the aim of reflecting the status as of the end of 2019. Therefore, some indicator data may have changed between the said period and the publication date of this report.

In country-level and sector-level sections, quantitative data in relation to the number of projects reflect the cumulative number of projects over the periods 1990-2017, 1990-2018, and 1990-2019. Otherwise, the data represent the status at each individual year. 


\section{Currency Equivalents}

(As of 31 May 2021)

PRs $1=\$ 0.006$

$\$ 1=$ PRs154.849 


\section{Overview}

Pakistan demonstrates a strong support for public-private partnerships (PPPs) at the federal and provincial levels. However, the country's regulatory framework remains fragmented both geographically and across industries. The Constitution gives provinces the responsibility for local infrastructure development; and Punjab and Sindh provinces have experience with legislation and PPP transactions. Certain sectors like national highways and power plants are still handled at the federal level. The power sector has implemented many PPPs, but not as part of the national dedicated PPP framework, and institutional knowledge has not been shared across stakeholders. The result is a fragmented system where PPPs in the power sector are thriving and attracting international investment, while PPPs in other sectors are less attractive to investors. In 2015, the government issued Pakistan 2025: One Nation, One Vision (otherwise known as Pakistan Vision 2025), a 10-year development plan that proposes a comprehensive policy regime to promote PPPs. ${ }^{1}$ The State Bank of Pakistan estimates that the country should spend 10\% of its gross domestic product (GDP) on infrastructure, but current spending is around one-third of that. ${ }^{2}$

Pakistan Vision 2025 lays down the foundation to fast-track Pakistan's development with the ultimate goal of transforming the country to become one of the top 10 economies in the world by 2047, its first centenary. The Vision document states that "Public-private partnerships will be promoted through a comprehensive policy regime. The enhanced private sector participation would be used for better infrastructure development and improving connectivity to facilitate private sector growth" (footnote 1).

In 2019, the Government of Pakistan introduced a 3-year Public Sector Development Plus Program (PSDP+) that involves 53 megaprojects with $\$ 33.58$ billion (PRs5.2 trillion at the end of 2019) investment to be implemented in 3 years during fiscal years (FYs) 2020-2023. PSDP+ projects will be implemented throughout Pakistan and are divided into two broad categories. At the start, there are 29 projects in 11 sectors with zero government investment, which are expected to inject a direct investment of $\$ 18.73$ billion (PRs2.9 trillion at the end of 2019) into the economy. The government, through public sector investment, will also provide an enabling environment to crowd in the private sector-fostering PPPs and joint ventures to reduce the burden on the PSDP. ${ }^{3}$

As approved by the National Economic Council in June 2020, the size of the Federal PSDP 2020-2021 is set at PRs650 billion, including foreign assistance of PRs72.5 billion. The Public Private Partnership Authority (PPPA) has been activated leveraging a private sector investment of PRs50 billion to complement public resources. During FY 2020/21, four projects with a tentative cost of PRs300 billion and an estimated investment of PRs50 billion would be implemented in PPP mode. To augment the PSDP, resources of the private sector

Government of Pakistan, Ministry of Planning, Development and Reform (Planning Commission). 2015. Pakistan 2025: One Nation, One Vision. Islamabad. https://www.pc.gov.pk/uploads/vision2025/Pakistan-Vision-2025.pdf.

2 The Economist Intelligence Unit. Infrascope 2018: Pakistan Country Profile. https://infrascope.eiu.com (accessed 1 September 2020).

3 J. Nasir. 2020. Govt to Introduce PSDP Plus Program with a Rs. 5.2 Trillion Investment. Pro Pakistani. https://propakistani.pk/2019/12/16/govt-tointroduce-psdp-plus-program-with-a-rs-5-2-trillion-investment/. 
would be leveraged with the help of the PPPA, attracting domestic and foreign direct investments in commercially viable projects. The PPPA will reduce transaction cost, ensure appropriate regulatory control, and provide the legal and economic mechanism to facilitate development initiatives. ${ }^{4}$

Based on the World Bank Private Participation in Infrastructure (PPI) database, the total number of infrastructure projects that attracted private investments and achieved financial closure from 1990 to 2019 were 108. The projects were predominantly in the energy sector (88\%), with the remaining $12 \%$ in ports, information and communication technology (ICT), airports, and waste disposal sectors. Of these, only one project in the energy sector was in a distressed state by 2020.

The total investment made in the 108 PPP projects is approximately $\$ 28.4$ billion (PRs4.40 trillion at the end of 2019). Figure 1 indicates the number of PPP projects that achieved financial closure, and those that were cancelled.

A detailed status-wise and sector-wise breakdown of projects is provided in Figure 2. As indicated, only one project in the energy sector is in a distressed state.

From a sector perspective, the energy sector attracted most PPPs followed by the port sector. While only two projects were witnessed in the ICT sector, the average size of a project reaching financial closure was highest in that sector at $\$ 454$ million (PRs70.3 billion at the end of 2019), followed by ports and energy sectors. The higher investments into energy and port sectors were due to the indexation of the United States dollar, which led the international banks and multilateral agencies to direct their investments into these two sectors. Figure 3 depicts the total investment and the average size of a PPP project in each of these sectors between 1990 and 2019.

Figure 1: Public-Private Partnership Projects Financially Closed and Cancelled, 1990-2019

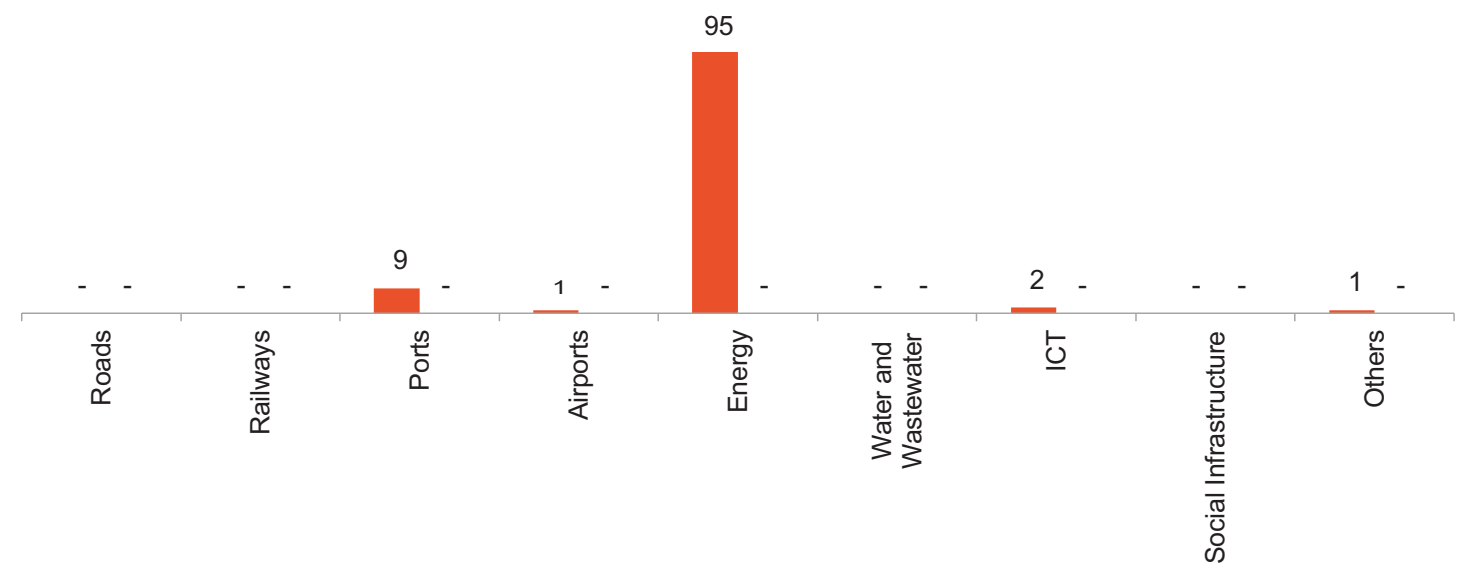

No. of financially closed projects $\quad$ No. of cancelled projects

ICT = information and communication technology.

Note: Total projects include projects that are active, cancelled, distressed, and concluded. The hyphen symbol (-) means there are no projects in the sector, or data are unavailable, or not applicable according to the database.

Source: World Bank. Infrastructure Finance, PPPs and Guarantees. Country Snapshots. Pakistan. https://ppi.worldbank.org/en/ snapshots/country/pakistan (accessed 1 September 2020).

4 Government of Pakistan, Ministry of Planning, Development and Special Initiatives (Planning Commission). 2020. Public Sector Development Programme 2020-21. Islamabad. https://www.pc.gov.pk/uploads/archives/PSDP_2020-21.pdf. 
Figure 2: Status of Public-Private Partnership Projects across Sectors

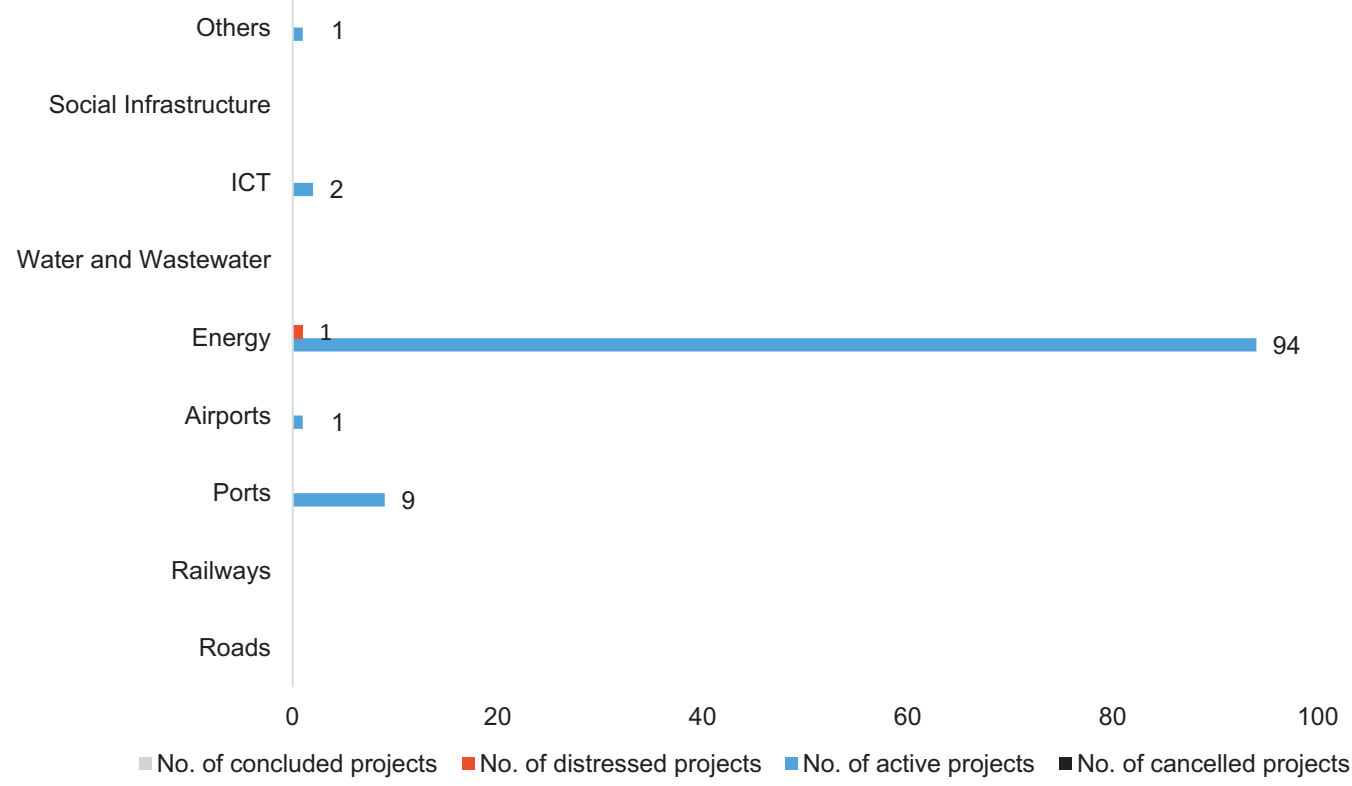

ICT = information and communication technology.

Note: Total projects include projects that are active, cancelled, distressed, and concluded.

Source: World Bank. Infrastructure Finance, PPPs and Guarantees. Country Snapshots. Pakistan. https://ppi.worldbank.org/en/ snapshots/country/pakistan (accessed 1 September 2020).

Figure 3: Investments in Public-Private Partnerships by Sector, 1990-2019

(\$ million)

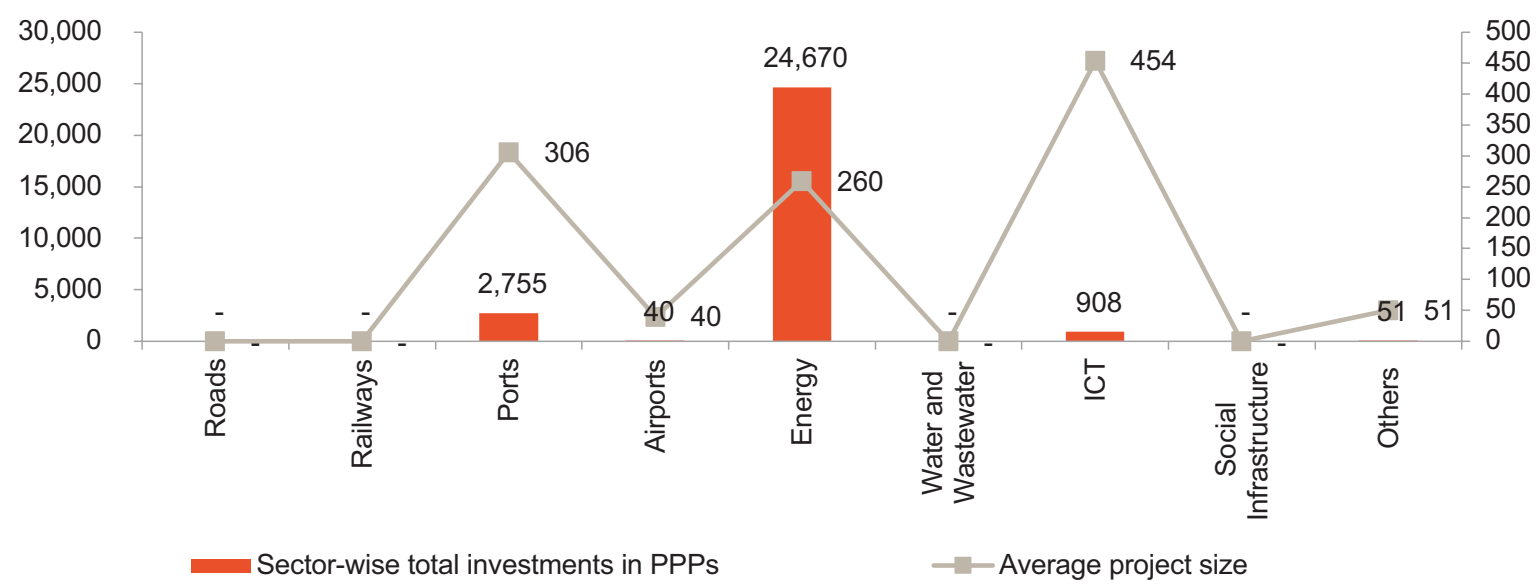

$\$=$ United States dollar, ICT = information and communication technology, PPP = public-private partnership.

Notes:

1. Total projects include projects that are active, cancelled, distressed, and concluded. The hyphen symbol (-) means there are no projects in the sector, or data are unavailable, or not applicable according to the database.

2. Data labels "40" and "51" (at the right side of axis labels "Airports" and "Others," respectively) refer to PPP investments, but their corresponding column chart is not visible because of the wide data scale.

Source: World Bank. Infrastructure Finance, PPPs and Guarantees. Country Snapshots. Pakistan. https://ppi.worldbank.org/en/ snapshots/country/pakistan (accessed 1 September 2020). 
Out of the 108 PPP projects that achieved financial closure, most investments have been sponsored by public and private entities from the United Kingdom and the People's Republic of China (PRC). Table 1 provides the list of the top 10 players.

From 1990 to 2019, a total of 14 PPP projects were procured through direct appointment, and 46 were through a competitive bidding process across various infrastructure sectors. Information on the remaining 48 projects is unavailable as per the World Bank database. Further, as per the database, a total of 64 projects have been procured through unsolicited route. Figure 4 indicates the modes by which PPP projects were procured during this period.

Table 1: Major Sponsors Active in the Infrastructure Sector

\begin{tabular}{|c|c|c|c|c|}
\hline \multirow[b]{2}{*}{ Private Sponsor } & \multirow[b]{2}{*}{ Country of Origin } & \multicolumn{2}{|c|}{ Total Investment } & \multirow{2}{*}{$\begin{array}{l}\text { Number of } \\
\text { PPP Projects }\end{array}$} \\
\hline & & $\$$ million & PRs billion & \\
\hline International Power & United Kingdom & 3,214 & 497.69 & 5 \\
\hline The Hub Power Company Limited & Pakistan & 2,967 & 459.44 & 4 \\
\hline Eden Enterprises & Malaysia & 1,888 & 292.36 & 1 \\
\hline China Three Gorges Corporation & People's Republic of China & 1,830 & 283.37 & 2 \\
\hline State Grid Corporation of China & People's Republic of China & 1,658 & 256.74 & 1 \\
\hline Hutchison Port Holdings & Hong Kong, China & 1,440 & 222.98 & 2 \\
\hline China Power Investment Corporation & Hong Kong, China & 1,436 & 222.36 & 1 \\
\hline Lucky Cement & Pakistan & 1,080 & 167.24 & 1 \\
\hline PSA Corporation Limited & Singapore & 709 & 109.79 & 3 \\
\hline Al Jomaih Holding Company & Saudi Arabia & 707 & 109.48 & 8 \\
\hline
\end{tabular}

$\$=$ United States dollar, PRs = Pakistan rupees, PPP = public-private partnership.

Source: World Bank. Infrastructure Finance, PPPs and Guarantees. Country Snapshots. Pakistan. https://ppi.worldbank.org/en/ snapshots/country/pakistan (accessed 1 September 2020).

Figure 4: Various Modes of Procuring Public-Private Partnership Projects, 1990-2019

54

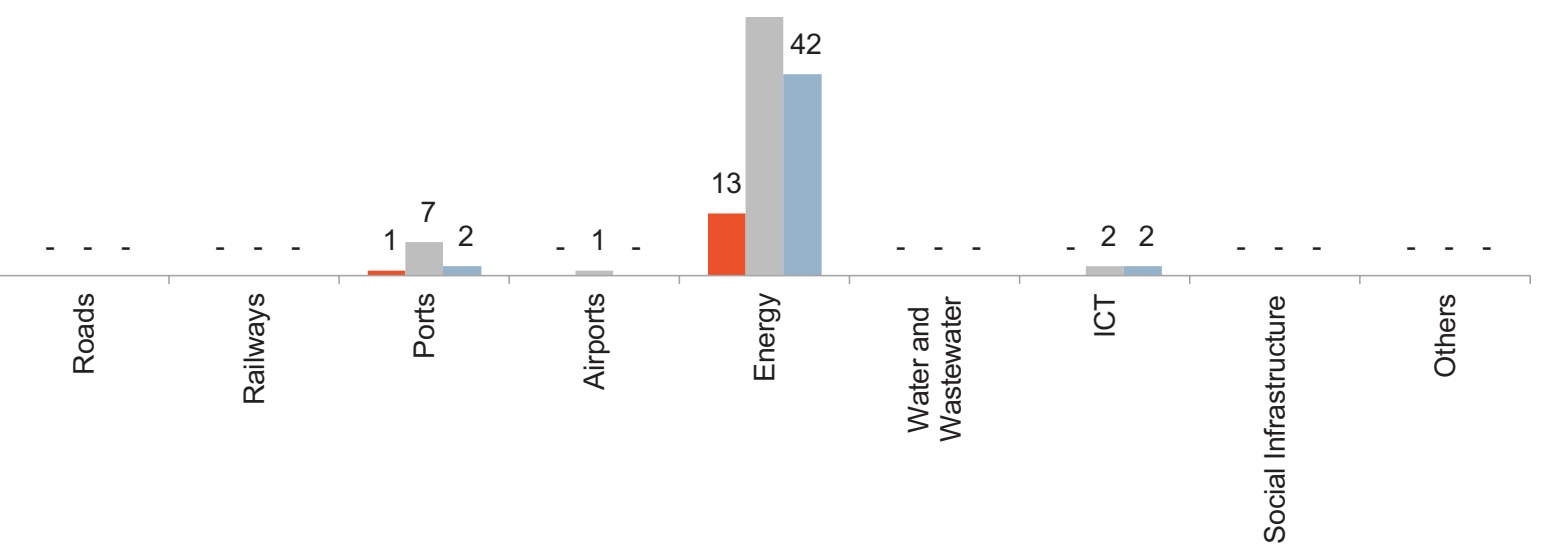

- Direct appointment $\quad$ Unsolicited bids $\quad$ Competitive bids

ICT = information and communication technology.

Note: Total projects include projects that are active, cancelled, distressed, and concluded. The hyphen symbol (-) means there are no projects in the sector, or data are unavailable, or not applicable according to the database.

Source: World Bank. Infrastructure Finance, PPPs and Guarantees. Country Snapshots. Pakistan. https://ppi.worldbank.org/en/ snapshots/country/pakistan (accessed 1 September 2020). 
As of 2019, based on the information accessed from the respective sector websites, the number of projects under preparation and procurement stages are reflected in Figure 5. The energy sector master plan provides a list of projects to be undertaken. However, the status of these projects is unclear and, therefore, not reflected in Figure 5. Similarly, in the case of social infrastructure, given that such projects have primarily been devolved to provinces under the country's constitution, there are several projects in the pipeline at the provincial level, but no such information is available at federal level. The respective sector write-up reflects the same. Figure 5 provides a list of projects under preparation and procurement as of 2019.

From 1990 to 2019, there was only one project that received viability gap funding (VGF) support under the federal government, while 36 projects (all in the energy sector) were supported through government guarantees. Figure 6, which reflects projects showcased in the World Bank Private Participation in Infrastructure (PPI) database, provides the number of projects that received direct and indirect government support.

During the period, there were only six PPP projects that were awarded based on user charges, while 78 PPP projects were based on government pay (off-take) model. Information on 29 projects is unavailable or not applicable, according to the database. Figure 7 provides the number of projects across sectors based on payment mechanisms.

Pakistan has witnessed active participation from foreign sponsors. While information on four projects was unclear, of those available, 54 projects attracted participation from foreign sponsors. The distribution of these projects across various infrastructure sectors is shown in Figure 8.

Figure 5: Public-Private Partnership Projects under Preparation and Procurement, 2019

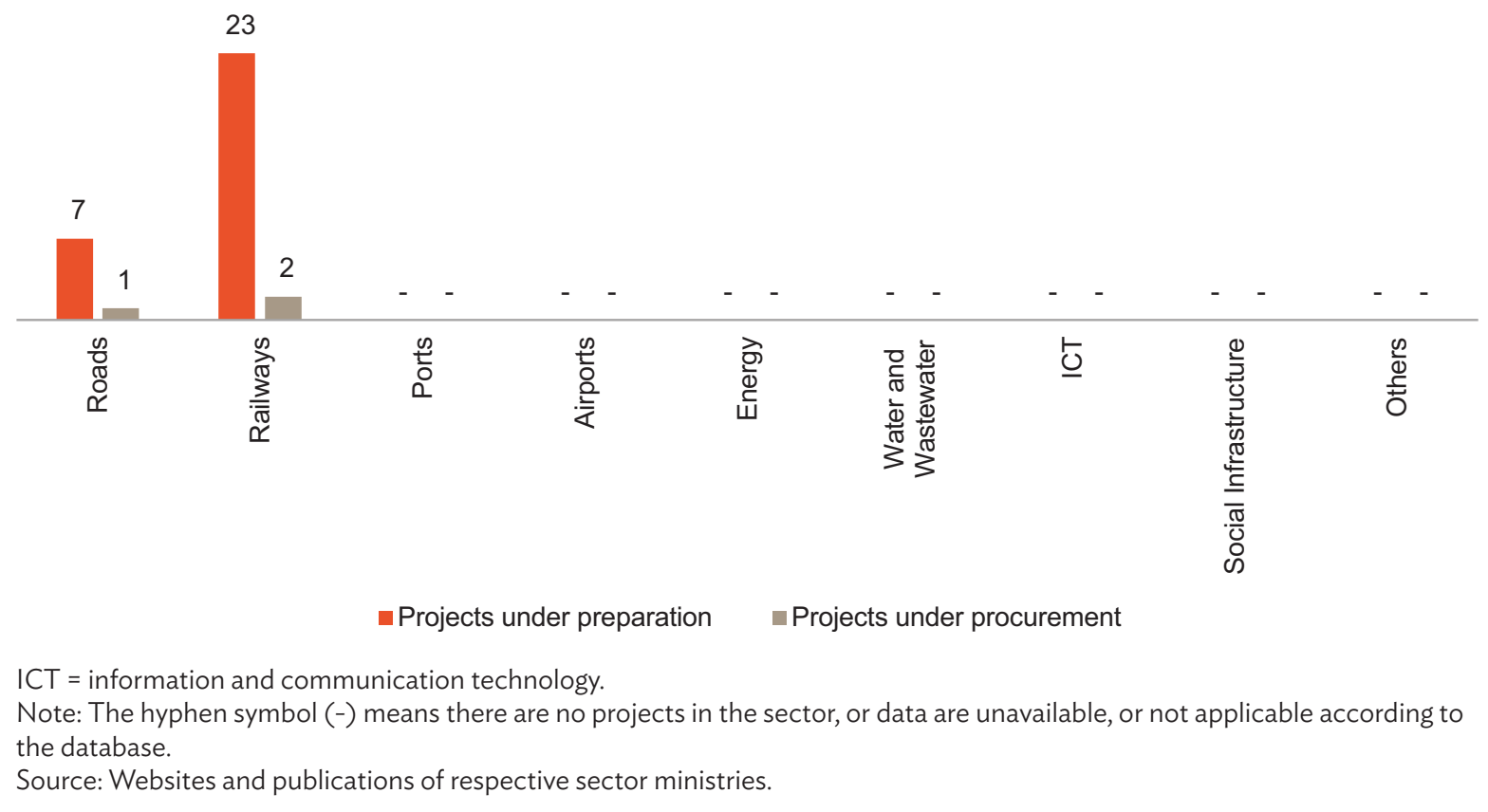


Figure 6: Public-Private Partnership Projects with Government Support, 1990-2019

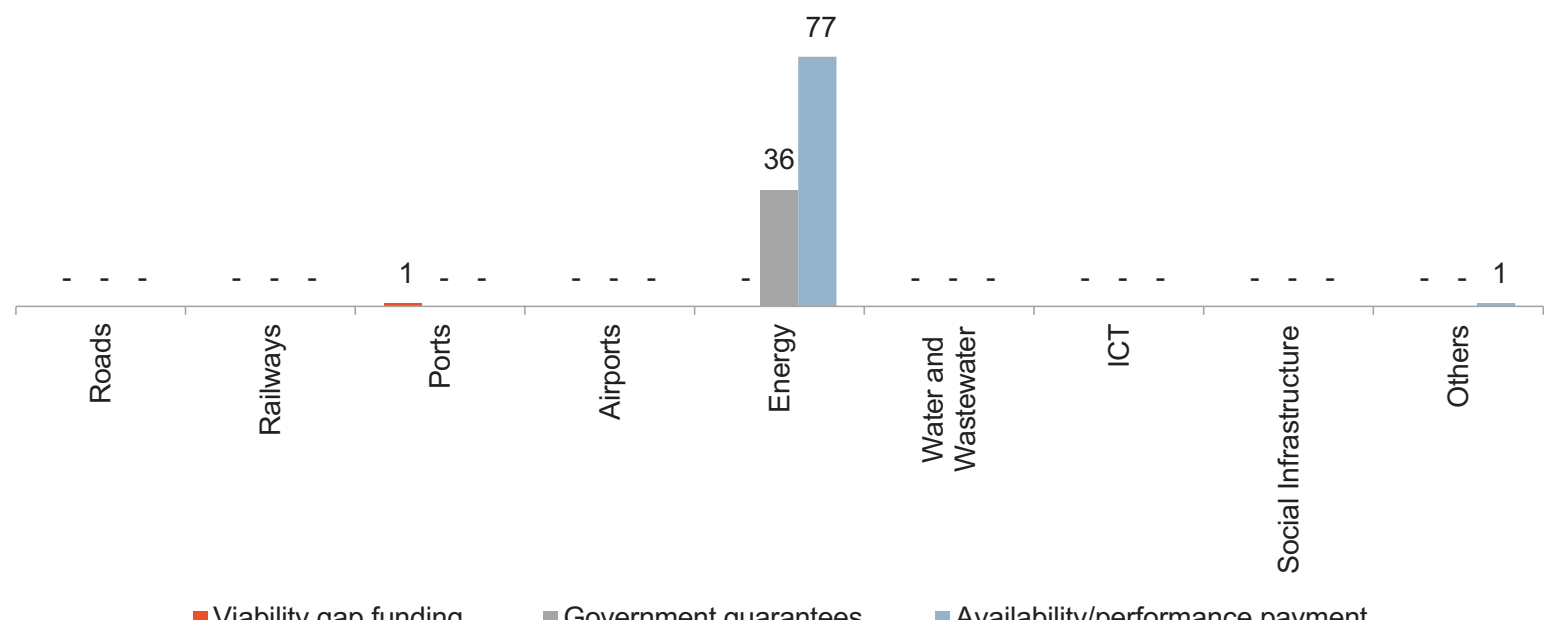

-Viability gap funding $\quad$ - Government guarantees $\quad$ Availability/performance payment

ICT = information and communication technology.

Note: Total projects include projects that are active, cancelled, distressed, and concluded. The hyphen symbol (-) means there are no projects in the sector, or data are unavailable, or not applicable according to the database.

Source: World Bank. Infrastructure Finance, PPPs and Guarantees. Country Snapshots. Pakistan. https://ppi.worldbank.org/en/ snapshots/country/pakistan (accessed 1 September 2020).

Figure 7: Payment Mechanism for Public-Private Partnership Projects, 1990-2019

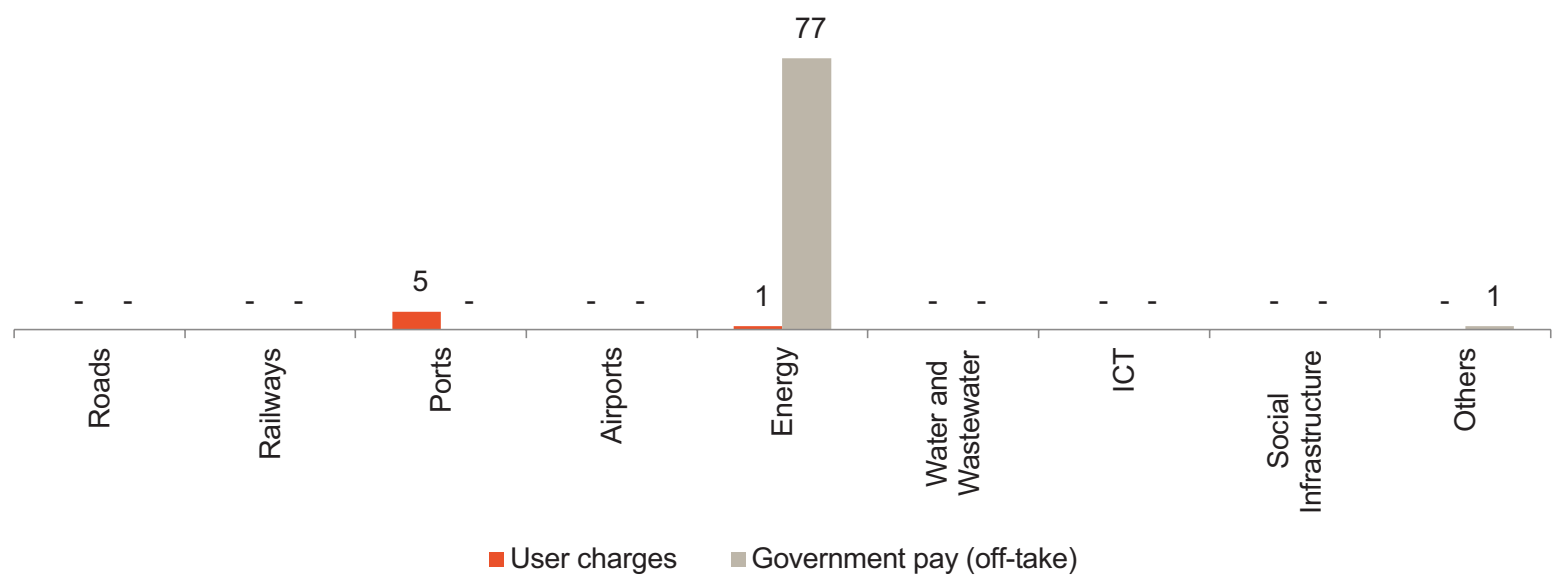

ICT = information and communication technology.

Note: Total projects include projects that are active, cancelled, distressed, and concluded. The hyphen symbol (-) means there are no projects in the sector, or data are unavailable, or not applicable according to the database.

Source: World Bank. Infrastructure Finance, PPPs and Guarantees. Country Snapshots. Pakistan. https://ppi.worldbank.org/en/ snapshots/country/pakistan (accessed 1 September 2020). 
Figure 8: Foreign Sponsor Participation, 1990-2019

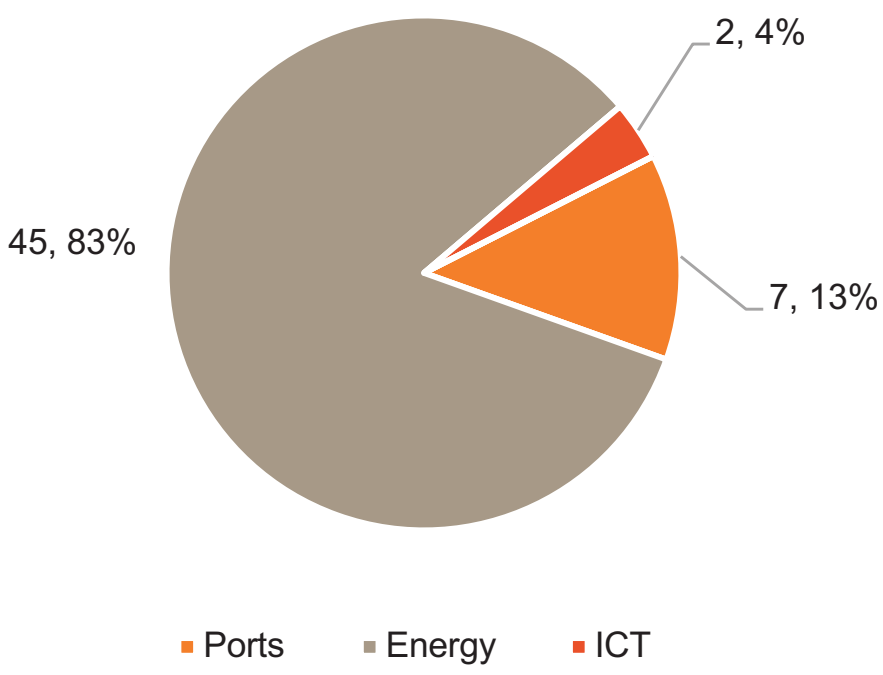

ICT = information and communication technology.

Note: Total projects include projects that are active, cancelled, distressed, and concluded.

Source: World Bank. Infrastructure Finance, PPPs and Guarantees. Country Snapshots. Pakistan. https://ppi.worldbank.org/en/ snapshots/country/pakistan (accessed 1 September 2020).

Though the PPP market in Pakistan has relatively matured because of constitutional provisions, much of the activity in PPPs has been at the provincial level. There have been various challenges to PPP implementation in Pakistan (footnote 2):

- The federal procurement policy provides a sufficient framework for transparency and competition, but projects are subject to sector and provincial laws, which add a layer of regulatory uncertainty. However, projects under the provincial PPP framework are not subject to federal PPP framework. Further, till recently, all energy projects higher than 50-megawatt capacity and ports were under the federal government. These projects have moved to provincial level only recently. However, the federal government gets involved during the final phases of the project development, mainly during the approval of government guarantee frameworks.

- The federal government recognizes the potential of PPPs in infrastructure development. However, the lack of coordination results in overlapping efforts and regulatory risks for the private sector. In addition, the framework for dispute resolution, conciliation, and arbitration is unclear. Many line ministries lack experience in negotiating contracts and rely on technical assistance from international consultants.

- Another challenge is the lack of long-term debt financing in the market. Currently, in majority of the cases, commercial banks only offer short- to medium-term loans, which shortens the payback period and financial viability for PPPs. However, there are instances where commercial banks have also provided 10- to 15-year loans on a floating rate basis linked to the Karachi Interbank Offered Rate. Such instances were exceptional and have been done under the regulatory regime, which provided them the certainty of returns (e.g., wind and solar projects that have feed-in-tariff pre-fixed protecting the revenue risk for the private sector). At the provincial level, capacity and the efficient use of resources are key challenges. Provincial governments have limited capacity to identify a pipeline of viable projects, develop these projects, and provide adequate guarantees and financing.

- The country does not have sufficient guidelines, checklists, and model documents for various sectors, which discourage private sector investments. 


\section{National Public-Private Partnership Landscape}

The public-private partnership (PPP) regulation in Pakistan is one of the government processes that shifted to the provincial level. As a result, the provincial governments have the primary responsibility of developing and implementing their own PPP policies and legislation. In this regard, the provincial governments of Punjab, Sindh, and Pakhtunkhwa have initiated key developments with respect to their individual PPP jurisdictions. ${ }^{5}$

- Establishment of a PPP policy and law in the Province of Punjab. The Punjab PPP Cell was initiated to support and develop the regulatory framework for PPPs within the province. The PPP Steering Committee, established by the provincial government of Punjab through notification, is the competent authority to approve, reject, or send back for reconsideration the PPP project proposals submitted by government agencies. As per the Punjab PPP Act 2019, the provincial government of Punjab shall establish the Public Private Partnership Authority (PPPA) that is responsible for implementing all the provisions of the Act, while the PPP Cell shall provide administrative and secretarial support to the Board.

- Establishment of a PPP policy and law in the Province of Sindh. The Sindh PPP unit was established with the primary function of enhancing the development of PPPs in the province.

- Establishment of a PPP law and framework in the Province of Khyber Pakhtunkhwa. The PPP legal framework of the province was developed and governed by the Khyber Pakhtunkhwa PPA Act. At the end of 2020, the Khyber Pakhtunkhwa PPP Act 2020 was passed, amending the 2017 PPP Act, to support a more enabling regulatory environment for PPPs in the province.

At the federal level, Pakistan did not have a PPP legislation until March 2017 when the Public Private Partnership Authority Act of 2017 (the Federal PPPA Act) was passed by the Parliament. Prior to the Federal PPP Act, private sector participation in infrastructure was propagated by the Pakistan Policy on Public Private Partnerships of 2010 (the 2010 PPP Policy). The 2010 PPP Policy detailed a set of guidelines for PPP development and the regulatory framework required to develop PPP projects. Pursuant to the 2010 PPP Policy, a statutory body, the Infrastructure Project Development Facility (IPDF), was established. Its role was to coordinate and facilitate the development of PPPs within Pakistan. Subsequent to the passing of the Federal PPP Act in 2017, the PPPA took that role from the IPDF to further the implementation of PPPs in the federal territory (footnote 5). In July 2020, an ordinance was passed to introduce an amendment to the 2017 PPP Law. In early 2021, the National Assembly approved this amendment, thereby enacting the Public Private Partnership Authority (Amendment) Act 2021 (PPPA Amendment Act 2021). ${ }^{6}$

5 ADB. 2019. Public-Private Partnership Monitor. Second Edition. Manila. https://www.adb.org/sites/default/files/publication/509426/ppp-monitorsecond-edition.pdf.

6 Government of Pakistan, PPPA. Public Private Partnership Authority (Amendment) Act 2021. Islamabad. http://www.senate.gov.pk/uploads/ documents/1612419098_271.pdf. 


\section{NATIONAL PUBLIC-PRIVATE PARTNERSHIP ENABLING FRAMEWORK}

\section{Public-Private Partnership Legal and Regulatory Framework}

\begin{tabular}{l|c} 
Parameter & \\
\hline Does the country have- & $\checkmark$ \\
\hline - National public-private partnership (PPP) law and PPP regulations? & $\checkmark$ \\
\hline - Public financial management laws and regulations? & $\checkmark$ \\
\hline - Sector-specific laws and regulations? & $\checkmark$ \\
\hline - Procurement laws and regulations? & $\checkmark$ \\
\hline - Environmental laws and regulations? & $\checkmark$ \\
\hline - Laws and regulations for social compliance? & $\checkmark$ \\
\hline - Laws and regulations governing land acquisition and ownership? & $\checkmark$ \\
\hline - Taxation laws and regulations? & $\checkmark$ \\
\hline - Employment laws and regulations? & UA \\
\hline - Licensing requirements? & PPP policy and guidelines \\
\hline What are the other components of the PPP legal and regulatory framework? & \\
\hline
\end{tabular}

$\checkmark=$ Yes, $x=$ No, NA = Not Applicable, UA = Unavailable.

The federal government and the provincial governments of Punjab, Sindh, and Khyber Pakhtunkhwa have each passed dedicated PPP legislation in their respective jurisdictions. PPP legislation in Balochistan is being developed through consultations with key stakeholders. In the federal territory of Pakistan, the Federal PPP Act is applicable to PPPs. The Federal PPP Act established the Public Private Partnership Authority (Federal PPPA), replacing the IPDF. All assets, powers, rights, and authorities of the IPDF were transferred to the PPPA. The provinces play an important role in the country's PPPs. The regulatory framework applicable for provinces is summarized in Table 2 (footnote 5).

\section{Table 2: Overview of Provincial Public-Private Partnership Frameworks in Pakistan}

\section{Province}

Punjab Public-Private Partnership (PPP) Law

\section{Regulatory Framework}

The PPP legal framework in Punjab is governed by the Punjab Public Private Partnership Act 2019 (which repealed the Punjab Public Private Partnership Ordinance 2014 and the Punjab Public Private Partnership for Infrastructure Act 2010) and by the Punjab Public Private Partnership Rules 2014 (Punjab PPP Rules). The Punjab PPP Act and Punjab PPP Rules are collectively referred to as Punjab PPP Laws.

In 2019, the provincial government of Punjab issued PPP Ordinance 2019, which was subsequently repealed and replaced by the Punjab Public Private Partnership Act 2019. The government has also issued the Viability Gap Funding (VGF) Guidelines for PPP projects in 2019 that are being revised to incorporate changes in the PPP Act 2019.

Under the Punjab PPP laws, there are identifiable entities (i.e., PPP Authority, PPP Cell, Board of the Authority, Executive Committee, and Risk Management Unit) to prepare, approve, and promote PPPs in the province. 
Table 2 continued

\section{Province}

Sindh Law

Khyber Pakhtunkhwa PPP Law

Balochistan PPP Law

\section{Regulatory Framework}

The PPP legal framework in Sindh is governed by the Sindh Public Private Partnership Act 2010 (Sindh PPP Act), as amended by the Sindh Public Private Partnership (Amendment) Act 2011 and the Sindh Public Private Partnership (Amendment) Act 2014.

Similar to the Punjab province, Sindh has also amended its PPP Act in 2018 with the Sindh Public Private Partnership (Amendment) Act 2018, but only making certain amendments and modifications to the existing Act rather than replacing it. Some of the key amendments include (i) introduction of the PPP Support Facility (PSF) mechanism that would subsume the VGF, effective from January 2022; (ii) detailing the financing elements of the existing Act; and (iii) dealing with unsolicited proposals, among others. In Sindh, there are four entities (i.e., PPP Policy Board, PSF, PPP Unit, and PPP Node) responsible for the identification, preparation, and implementation of PPP projects, each having different roles and functions.

Khyber Pakhtunkhwa Public Private Partnership Act 2020, which amended the 2017 PPP Act, has already been passed by the provincial government in the latter part of 2020 and is currently in its implementation process. (see https://www.pakp.gov.pk/wpcontent/uploads/Public-Private-Partnership-act-2020-Act-No.XLII-of-2020.pdf). The PPP Act 2020 has simplified the rules and regulations to create a more facilitative and cohesive partnership and to promote the efficient and sustainable delivery of PPP initiatives in the province.

In Khyber Pakhtunkhwa, there are three entities (i.e., PPP Committee, PPP Unit, and PPP Node) responsible for the identification, preparation, and implementation of PPP projects, each having different roles and functions.

Balochistan has not yet developed a provincial PPP legal framework. Furthermore, the Federal PPP Act does not extend to Balochistan since the Federal PPP Act defines PPPs as a commercial transaction between an implementing agency and a private party. Accordingly, Balochistan, being a provincial government, does not fall within the scope of an implementing agency.

Source: Asian Development Bank. 2019. Public-Private Partnership Monitor. Second Edition. Manila. https://www.adb.org/sites/default/ files/publication/509426/ppp-monitor-second-edition.pdf.

\section{Evolution of Public-Private Partnership Regulation at Federal Level}

The federal government through the Ministry of Finance initiated the PPP program in 2006 by establishing the IPDF after obtaining approval of the Prime Minister of the Pakistan. The primary mandate of the IPDF was to promote PPPs in Pakistan, along with the provision of advisory and facilitation services for ministries, autonomous bodies, and other government-owned entities (implementing agencies) to develop, structure, and procure PPP projects under a PPP modality?

For the convenience of the private sector and to govern the role of the IPDF, the federal government approved the PPP Policy in 2007 and then an amendment in 2010. The IPDF continued providing facilitation and advisory services in accordance with the approved policy till 2017. On 30 March 2017, the parliament passed the Public Private Partnership Authority Act (No. VIII) 2017 (referred to as the Act) through which all assets, powers, rights, and authorities of the IPDF were transferred to and vested in the PPPA. The Act, among other things, mandated the PPPA to establish a regulatory framework to attract domestic and foreign private investment in the development of public assets and related services through fair, transparent, and competitive bidding process, thereby reducing transactional costs through the provision of appropriate regulatory controls (footnote 7).

7 Government of Pakistan, PPPA. 2018. Newsletter PPPA. 1 (1). Islamabad. November. https://www.pppa.gov.pk/Sitelmage/Misc/files/NewsLetters/ Newsletter-2\%20Nov\%202018\%20(Vol\%201).pdf. 
To ensure the continuity of advisory and facilitation services, which were being provided by the former IPDF, the Act has provided for the conversion of the IPDF into the PPPA. Therefore, the PPPA, under the provisions of the Act, shall continue to provide advisory and facilitation services to all implementing agencies for the development of financial and legal structuring of the PPP projects. The PPPA will, however, assist the implementing agencies in carrying out technical studies of the PPP projects (footnote 7).

In July 2020, the Government of Pakistan approved an amendment to the existing PPP Act of 2017 with the Public Private Partnership Authority (Amendment) Ordinance 2020. In early 2021, the Parliament approved the amendment, thereby enacting the Public Private Partnership Authority (Amendment) Act 2021. The PPPA Amendment Act 2021 elaborates the preamble, clearly enhancing the role of the Act and the PPPA, and aims to

- establish a regulatory framework to execute PPPs in Pakistan so as to promote domestic and foreign private investment in development projects;

- increase the availability of public infrastructure and service delivery, and improve their reliability and quality to accelerate economic growth and achieve the social objectives of the government;

- mobilize private sector resources for financing, construction, and operation and maintenance (O\&M) of development projects;

- improve efficiency of management and O\&M of development projects in the public sector by introducing modern technologies and management techniques; and

- reduce transaction costs, ensure appropriate regulatory controls, and promote transparency and accountability in carrying out development projects (footnote 6).

Until 2020, the Public Procurement Regulatory Authority (PPRA) Ordinance 2002 was applicable for regulating public procurement of goods, services, and works in the public sector and for overseeing public procurement, which was defined as "acquisition of goods, services, or construction of any works financed wholly or partly out of the Public Fund, unless excluded otherwise by the Federal Government." This signified that the PPRA Ordinance 2002 and the subsequently issued rules were applicable for PPP projects only in cases "in which the Federal Government and the private party have joint equity or ownership through a corporate body, and procurement is made by such body," and not to the projects "in which the Federal Government does not have any equity of ownership, and procurement is made by the private party." In July 2020, the Government of Pakistan issued a gazette notification amending the PPRA Ordinance 2002 by way of the Public Procurement Regulatory Authority (Amendment) Ordinance 2020. ${ }^{9}$ One of the significant amendments made to the PPRA Ordinance 2002 is the modification of the definition of public procurement into acquisition of goods, services, or construction of any works financed wholly or partly out of the public fund. The amendment also includes disposal of public assets and commercial transactions between the procuring agency and the private party, in terms of which the private party is allowed to

- perform a procuring agency's assigned functions, including O\&M, on its behalf;

- assume the use of public asset; or

- receive a benefit either from budget or revenue of the federal government or from fees or charges to be collected by the private party for performing the procuring agency's function or any combination thereof.

Government of Pakistan, PPRA. 2015. PPRA Procurement Code. 4th Edition. Islamabad. https://www.ppra.org.pk/doc/code4.pdf.

Government of Pakistan, PPRA. 2020. Public Procurement Regulatory Authority (Amendment) Ordinance, 2020. Islamabad. https://ppra.org.pk/doc/ ordinance2020.pdf. 
Based on the above modification, it is inferred that from July 2020 onwards, the PPP project structures, such as management contracts, O\&M contracts, and other forms of concessions (partly or fully financed by a public entity) where private sector is involved, shall be guided by the PPRA (Amendment) Ordinance 2020.

\section{Types of Public-Private Partnership}

Regulations in Pakistan at the federal level do not specify nor discourage any specific PPP types; it is silent on the PPP types. The provincial PPP regulations, however, identify specific PPP types in their respective laws as indicated in Table 3.

\section{Table 3: Types of Public-Private Partnerships in the Provinces of Pakistan}

\begin{tabular}{l|l}
$\begin{array}{l}\text { Province } \\
\begin{array}{l}\text { Punjab Public-Private } \\
\text { Partnership (PPP) Law }\end{array}\end{array}$ & $\begin{array}{l}\text { Types of Public-Private Partnership } \\
\text { own-operate-transfer, build-transfer-operate, contract-add-operate, develop-operate- } \\
\text { transfer, joint venture, management contract, rehabilitate-operate-transfer, rehabilitate- } \\
\text { own-operate, and service contract }\end{array}$ \\
\hline Sindh PPP Law & $\begin{array}{l}\text { Build-operate-transfer, design-build-finance-operate, and any other variant of PPP. } \\
\text { Additionally, the following modes are identified in Part IV of the Sindh Public Procurement } \\
\text { Rules 2010: service contract, management contract, lease contract, build-own-operate, } \\
\text { build-own-operate-transfer, build-lease-transfer, build-transfer, rehabilitate-operate- } \\
\text { transfer, and any combination or variation of the above modes or any other arrangement } \\
\text { under PPP mode approved by the Sindh Public Procurement Regulatory Authority. }\end{array}$ \\
\hline Khyber Pakhtunkhwa PPP & $\begin{array}{l}\text { Build-operate-transfer, build-own-operate-transfer, design-build-finance-operate, and } \\
\text { any other variant of PPP. }\end{array}$ \\
\hline Law
\end{tabular}

Source: Asian Development Bank. 2019. Public-Private Partnership Monitor. Second Edition. Manila. https://www.adb.org/sites/default/ files/publication/509426/ppp-monitor-second-edition.pdf.

Given the types of PPP being adopted in the three provinces, it could be construed that, at the federal level, Pakistan allows for all standard forms of PPPs-i.e., build-operate-transfer (BOT), build-ownoperate-transfer (BOOT), build-own-operate (BOO), design-build-finance-operate-transfer (DBFOT), management contracts, annuity-based agreements, and O\&M agreements. The generic definitions of some of these forms are provided below:

- BOT user fees, where the private party builds and operates the project assets. The project assets are transferred back to the government contracting agency at the end of the contract period. The private sector entity recovers the investment by way of charging user fees. These user fees are, in most cases, regulated by the government or are predetermined.

- BOT annuity contracts, where the private sector typically builds and operates the project assets during the concession period. However, instead of charging the users directly for the services rendered, in annuity models, the government contracting agency pays the private sector operator availability or annuity payments based on the availability of the services at certain predefined performance standards.

- BOOT, which is similar to BOT with the only difference that the private sector also owns the project assets over the duration of the PPP concession period.

- BOO, which is similar to BOOT with the only difference that the project assets are not transferred back to the government contracting agency at the end of the PPP concession period.

- DBFOT, where the private party is responsible for designing, financing, constructing, operating, and maintaining the project assets. At the end of the concession period, the project assets are transferred 
back to the government contracting agency. The ownership of the project asset is with the government contracting agency. A variation to this is where the ownership during the project tenure is with the private sector, in which case, it would become a design-build-finance-own-operate-transfer (DBFOOT) contract structure.

- O\&M agreements, where the private party would be in charge of O\&M of project assets and may also be required to arrange financing.

While the federal regulations are silent on PPP types, the PPP Policy 2010 classifies PPPs based on the types of funding for the projects. As per the PPP Policy 2010, there can be several potential sources of revenue or income depending on the type of PPP project and the likely financial performance of the project. These revenue sources may include the following: ${ }^{10}$

- Tariff-based PPP projects. In the case of financially viable projects, project revenue is derived solely from user charges and/or tariffs. Initial tariffs and subsequent tariff escalation are initially determined through feasibility studies conducted by contracting agencies to ensure an appropriate or market acceptable rate of return based on an efficient operation. The competitive bidding process will minimize the initial government-estimated tariffs and the subsequent escalation (footnote 10).

- Unitary or annuity type revenue. The government pays the concessionaire for providing the infrastructure and related services either in an agreed fixed amount each year of operation or an amount based on the future situation (e.g., future traffic levels). Such payments can either be linked with user charges or can be independent of them. The project feasibility study will recommend a system of annual unitary payments based solely on outputs (i.e., specific project targets met by the concessionaire) (footnote 10).

- Projects requiring subsidy. For projects that have been appraised as not being 'bankable' without support, such support may be offered by the Government of Pakistan and can comprise various types and come from various sources. This is to ensure that with such support, the project is ultimately financially viable or bankable and is therefore attractive to the private sector. Any proposed subsidy will be finally determined through competitive bidding to ensure the lowest liability for the government (footnote 10).

\section{Eligible Sectors for Public-Private Partnerships}

Regulations at the federal level are silent about any specific sector criteria for undertaking PPPs. However, the PPP Policy of 2010 lists a broad range of sectors, including, but not limited to

- transport and logistics (federal, provincial, and municipal roads; rail, seaports, airports, and fishing harbors; warehousing, wholesale markets, slaughterhouses, and cold storage);

- mass urban public transport (integrated bus systems, intracity and intercity rail systems);

- local government services (water supply and sanitation, solid waste management, low-cost housing, health care and/or education, and skills development facilities);

- energy projects (hydroelectric and captive power generation project, hydro and thermal power generation projects);

10 Government of Pakistan, PPPA. 2010. Pakistan Policy on Public Private Partnerships: Private Participation in Infrastructure for Better Public Services. Islamabad. http:/www.lcwu.edu.pk/ocd/cfiles/City\%20and\%20Regional\%20Planning/CRP-45/Lec5PPPPolicyFINAL14-May-2010.pdf. 
- tourism projects (cultural centers, entertainment and recreational facilities, and other tourism-related infrastructure);

- industrial projects (industrial parks, special economic zones, and related projects);

- irrigation projects (some of these are combined with power generation); and

- social infrastructure (education, culture, and health infrastructure) (footnote 10).

Based on the qualification provided in the PPP Policy, it could be presumed that the PPP could be applied to various infrastructure sectors in the country. PPPs are applied typically across various economic and social infrastructure sectors. Table 4 presents a broad classification of sectors based on standard practices.

Table 4: Eligible Sectors and Subsectors for Public-Private Partnerships

\begin{tabular}{|c|c|c|}
\hline Sectors & Subsectors & Asset/Facility Type \\
\hline \multirow[t]{6}{*}{$\begin{array}{l}\text { Transportation } \\
\text { infrastructure }\end{array}$} & Road infrastructure & $\begin{array}{l}\text { Main roads, collector roads and local roads, toll roads, } \\
\text { toll bridges }\end{array}$ \\
\hline & $\begin{array}{l}\text { Rail and mass transit } \\
\text { infrastructure }\end{array}$ & Railway facilities, urban mass transportation \\
\hline & Waterways infrastructure & Infrastructure for crossing at sea, river, or lake \\
\hline & Seaport infrastructure & Port facilities and passengers and cargo terminal \\
\hline & Airport infrastructure & Airport facilities \\
\hline & Logistics infrastructure & $\begin{array}{l}\text { Warehousing, wholesale markets, slaughterhouses, and cold } \\
\text { storage }\end{array}$ \\
\hline \multirow{4}{*}{$\begin{array}{l}\text { Water, wastewater, } \\
\text { and solid waste } \\
\text { management } \\
\text { infrastructure }\end{array}$} & $\begin{array}{l}\text { Water resources and irrigation } \\
\text { infrastructure }\end{array}$ & $\begin{array}{l}\text { Bulk water carrier pipelines, irrigation networks and water storage } \\
\text { infrastructure (including its supporting structures, among others) } \\
\text { reservoir, dam, and weir }\end{array}$ \\
\hline & Water supply infrastructure & Raw water unit, production unit, distribution unit \\
\hline & Wastewater infrastructure & $\begin{array}{l}\text { Centralized wastewater management systems including service } \\
\text { unit, collection unit, processing unit, final disposal unit, water } \\
\text { discharge pipeline, and sanitation } \\
\text { Local wastewater management system including local processing } \\
\text { unit, transport unit, sludge treatment unit, final disposal unit, } \\
\text { water discharge pipeline, and sanitation }\end{array}$ \\
\hline & $\begin{array}{l}\text { Solid waste management } \\
\text { infrastructure }\end{array}$ & Transportation, processing, final waste processing \\
\hline \multirow[t]{2}{*}{ ICT infrastructure } & $\begin{array}{l}\text { Telecommunication } \\
\text { infrastructure }\end{array}$ & $\begin{array}{l}\text { Telecommunication network, passive infrastructure such as } \\
\text { transmission media cable ducts }\end{array}$ \\
\hline & $\begin{array}{l}\text { Information technology and } \\
\text { informatics infrastructure }\end{array}$ & e-Government infrastructure \\
\hline \multirow{4}{*}{$\begin{array}{l}\text { Energy and } \\
\text { electricity } \\
\text { infrastructure }\end{array}$} & Power generation & Power generation facilities \\
\hline & $\begin{array}{l}\text { Power transmission and } \\
\text { subtransmission }\end{array}$ & Power transmission and main substation facilities \\
\hline & Power distribution & Power distribution facilities \\
\hline & $\begin{array}{l}\text { Energy conservation } \\
\text { infrastructure }\end{array}$ & NA \\
\hline
\end{tabular}


Table 4 continued

\begin{tabular}{|c|c|c|}
\hline Sectors & Subsectors & Asset/Facility Type \\
\hline \multirow[t]{4}{*}{ Social infrastructure } & Education infrastructure & Education and skills development facilities \\
\hline & Health infrastructure & $\begin{array}{l}\text { Hospital (i.e., hospital building, hospital infrastructure, and } \\
\text { medical equipment; basic health service facility, such as building, } \\
\text { infrastructure, and medical equipment for health center and/or } \\
\text { clinic; health laboratory, such as health laboratory building, health } \\
\text { laboratory, infrastructure, and laboratory equipment) }\end{array}$ \\
\hline & Public housing & Low-cost housing \\
\hline & Government buildings & NA \\
\hline \multirow[t]{6}{*}{ Other infrastructure } & Zone infrastructure & $\begin{array}{l}\text { Industrial projects including industrial parks, special economic } \\
\text { zones, and related projects }\end{array}$ \\
\hline & $\begin{array}{l}\text { Oil and gas infrastructure, } \\
\text { including bioenergy }\end{array}$ & Processing, storage, transportation, distribution \\
\hline & Tourism infrastructure & $\begin{array}{l}\text { Cultural centers, entertainment and recreational facilities, and } \\
\text { other tourism-related infrastructure }\end{array}$ \\
\hline & $\begin{array}{l}\text { Sports, arts, and culture facility } \\
\text { infrastructure }\end{array}$ & Sports recreation facilities \\
\hline & Penitentiary infrastructure & NA \\
\hline & Traditional market & NA \\
\hline
\end{tabular}

ICT = information and communication technology, NA = not applicable.

Source: Government of Pakistan, Public Private Partnership Authority. 2010. Pakistan Policy on Public Private Partnerships: Private Participation in Infrastructure for Better Public Services. Islamabad. http://www.lcwu.edu.pk/ocd/cfiles/City\%20and\%20Regional\%20 Planning/CRP-45/Lec5PPPPolicyFINAL14-May-2010.pdf.

Given that the PPP Policy of 2010 states that the sector list is inclusive and not exhaustive, it may be inferred that the PPPA may consider other projects that are not in the sector list indicated in Table 4.

\section{Public-Private Partnership Institutional Framework}

\section{Parameter}

Does the country have a national public-private partnership (PPP) unit?

What are the functions of the national PPP unit?

- Supporting the design and operationalization of the national PPP enabling framework?

- Helping develop a national PPP pipeline?

- Supporting the arrangement of funding for project preparation (budgetary allocations, technical assistance funding from multilateral development agencies, operating a dedicated project preparation/ project development fund)?

- Guidance for project preparation to, and coordination with, the government agencies responsible for sponsoring the projects?

- Making recommendations to the PPP Committee and/or other approving authorities to provide approvals associated with various stages of the PPP process?

$\checkmark=$ Yes

a The Public Private Partnership Authority (PPPA) Amendment Act 2021 defines one of the functions of the PPPA as "subject to the rules and regulations made hereunder, advise, facilitate and actively support the implementing agency to develop and structure, as needed, the qualified projects at all stages of the project cycle such as identification, planning, tendering, bidding and contract award and implementation." Further, the PPPA is expected to work with federal ministries. It is also helping track the development of the Public Sector Development Plus Program (PSDP+) pipeline of possible projects with private sector investment potential. 
The Public Private Partnership Authority (also referred to as PPPA, the Authority, or P3A) was established by virtue of the PPPA Act 2017. It was notified in 2018 and rechristened P3A as per PPPA Amendment Act 2021 (footnote 6). The PPPA functions under the administrative control of the Ministry of Finance. Its mandate, among others, are to regulate PPP transactions; assist federal implementing agencies in developing, structuring, and procuring their infrastructure projects through private sector investment; and approve PPP transactions that provide value for funding solution to the public sector. The supervisory ministry has been changed from Ministry of Finance to Ministry of Planning, Development, Reforms, and Strategic Initiatives. The PPPA Amendment Act 2021 also elaborates on the powers of the PPPA, the extracts of which are provided below (footnote 6):

- ensure that "qualified projects" are consistent with national and sectoral strategies;

- ensure value for money by conducting an analysis to evaluate qualified projects in the manner as may be prescribed;

- conduct appraisal and project risk analysis for qualified projects;

- assess all funding requirements;

- advise, facilitate, and actively support the implementing agency to develop and structure, as needed, the qualified projects at all stages of the project cycle such as identification, planning, tendering, bidding, contract award, and implementation;

- standardize contractual provisions and develop sector-specific provisions and templates including a model PPP agreement for qualified projects;

- analyze and assess annuity, user-based, hybrid, and other financial models for qualified projects; and

- interact, collaborate, and liaise with international agencies.

\section{Entities Responsible for Public-Private Partnership Project Identification, Approval, and Oversight}

\begin{tabular}{|c|c|}
\hline Parameter & \\
\hline $\begin{array}{l}\text { Who is responsible for identifying, preparing, and procuring the } \\
\text { PPP projects? }\end{array}$ & Implementing agencies, P3A \\
\hline $\begin{array}{l}\text { Is there a PPP Committee for providing approvals at various stages of } \\
\text { PPP projects? }\end{array}$ & $\checkmark(P 3 W P)$ \\
\hline $\begin{array}{l}\text { Who are the approving authorities other than the PPP Committee for } \\
\text { PPP projects? }\end{array}$ & $\begin{array}{c}\text { Wherever relevant, one or all of- } \\
\text { Risk Management Unit, Board of P3A, } \\
\text { ECNEC }\end{array}$ \\
\hline $\begin{array}{l}\text { Does the country have an independent think tank for various PPP planning, } \\
\text { budgeting, and policy decisions? }\end{array}$ & $x$ \\
\hline Is there a legislature for the PPP program oversight? & $\sqrt{a}$ \\
\hline
\end{tabular}


The PPPA Amendment Act 2021 also proposes establishing the Public Private Partnership Working Party (P3WP), which, among other things, is responsible for

- granting approval of the project concept proposal submitted by the PPPA,

- granting approval of the project qualification proposal submitted by the PPPA, and

- performing other functions as may be prescribed from time to time.

Section 14 of the PPPA Amendment Act 2021 provides guidance on the approvals required for the qualified projects. Prior to the execution of the PPP agreement by the implementing agency, the Act states that all qualified projects should obtain approval from

- the P3WP for the project qualification proposal;

- the Risk Management Unit for the project (in accordance with PPPA Amendment Act 2021, Section 12A);

- the Board of the Authority for the project proposal; and

- the Executive Committee of the National Economic Council for the project proposal (in the event the qualified project meets certain prescribed criteria, and any other approvals as may be prescribed from time to time).

\section{Entities Responsible for Public-Private Partnership Project Monitoring}

\begin{tabular}{l|l} 
Parameter & \\
Monitoring of PPP projects post-commercial close? & Implementing agency, Board of P3A \\
\hline $\begin{array}{l}\text { Supporting the monitoring and management of fiscal risks and liabilities } \\
\text { from PPP projects for the Ministry of Finance? }\end{array}$ & Risk management unit, implementing agency \\
\hline
\end{tabular}

P3A = Public Private Partnership Authority, PPP = public-private partnership.

One of the key responsibilities of implementing agencies as per PPPA Amendment Act 2021 is to "monitor and implement the project in accordance with the public-private partnership agreement." It is thereby clear that the implementing agencies are responsible for monitoring the PPP projects after the award of the project.

For qualified projects, the power to monitor is assigned to the Board of P3A. One of the powers of the Board of P3A, as per the PPPA Amendment Act 2021, is "monitoring, in respect of qualified projects, the implementation of public-private partnership agreements, including in terms of the financial situation and the construction of physical assets and service delivery."

The PPPA Amendment Act 2021 proposes to establish a risk management unit which shall be managed, controlled, and administered by the Finance Division of the Federal Government for the PPPs. The risk management unit is currently envisaged to be part of the Debt Policy Coordination Office within the Ministry of Finance. As per the Act, the risk management unit shall be responsible for fiscal oversight and evaluation of fiscal and contingent liability exposure for all qualified projects. Such evaluation may be required as prescribed by the Authority in consultation with the Finance Division. The Act also provides that, in respect of any project that is not a qualified project, each implementing agency shall provide the risk management unit all the information about such project as may be prescribed by the Authority in consultation with the Finance Division. 


\section{The Public-Private Partnership Process}

\begin{tabular}{|c|c|}
\hline Parameter & \\
\hline $\begin{array}{l}\text { Does the public-private partnership (PPP) legal and regulatory framework provide for a PPP } \\
\text { implementation process covering the entire PPP lifecycle? }\end{array}$ & $x$ \\
\hline $\begin{array}{l}\text { Feasibility assessment stage } \\
\text { - Technical feasibility? } \\
\text { - Socioeconomic feasibility? } \\
\text { - Environmental sustainability? } \\
\text { - Financial feasibility? } \\
\text { - Fiscal affordability assessment? } \\
\text { - Legal assessment? } \\
\text { - Risk assessment and PPP project structuring? } \\
\text { - } \text { Value for money assessment? }\end{array}$ & $\begin{array}{l}\checkmark \\
\checkmark \\
\checkmark \\
\checkmark \\
\checkmark \\
\checkmark \\
\checkmark \\
\checkmark \\
\checkmark\end{array}$ \\
\hline Is the PPP procurement plan required to be prepared? & $\checkmark$ \\
\hline Is there a need to set up a separate PPP procurement committee? & $x$ \\
\hline Is competitive bidding the only method for selection of PPP private developer? & $x$ \\
\hline $\begin{array}{l}\text { Is the prequalification stage necessary? Or does the PPP legal and regulatory framework allow flexibility } \\
\text { to skip the prequalification stage? }\end{array}$ & $\begin{array}{l}\text { Prequalification is } \\
\text { not mandatory }\end{array}$ \\
\hline $\begin{array}{l}\text { Does the PPP legal and regulatory process provide the option to the preferred bidder for contract } \\
\text { negotiations? }\end{array}$ & $\checkmark$ \\
\hline $\begin{array}{l}\text { Does the PPP legal and regulatory framework allow unsuccessful bidders to challenge the award/ } \\
\text { submit complaints? }\end{array}$ & $\checkmark$ \\
\hline $\begin{array}{l}\text { What is the maximum time allowed for submitting a complaint/challenging the award by unsuccessful } \\
\text { bidders from the announcement of the preferred bidder? }\end{array}$ & 15 days \\
\hline Does the PPP legal and regulatory framework provide for transparency? & $\checkmark$ \\
\hline Which of the following are required to be published? & \\
\hline - Findings from the feasibility assessment? & $x$ \\
\hline - Procurement notice & $\checkmark$ \\
\hline - Outcome of stakeholder consultations from market sounding? & $x$ \\
\hline - Clarifications to prequalification queries? & $x$ \\
\hline - Prequalification results? & $\checkmark$ \\
\hline - Clarifications to pre-bid queries? & $\checkmark$ \\
\hline - Results for the bid stage and selection of preferred bidder? & $\checkmark$ \\
\hline $\begin{array}{l}\text { - Final concession agreement to be entered between the government agency and the preferred bidder? } \\
\text { And other PPP project agreements executed between the government agency and the preferred bidder? }\end{array}$ & $x$ \\
\hline Confidentiality & $\checkmark$ \\
\hline
\end{tabular}

$\checkmark=$ Yes, $x=$ No.

Section 19 of the PPPA Amendment Act 2021 defines the aspect related to the agreement negotiation and indicates that,

The implementing agency shall, after all applicable approvals have been obtained in accordance with Section 17, invite the successful private party bidder for negotiation of the public-private partnership agreement on such terms and conditions as may be prescribed from time to time. 
The PPPA Amendment Act 2021 also provides the implementing agencies a scope for entering into negotiated procurement in cases where the federal government approves such a case. Section 20 of the PPPA Amendment Act 2021 states,

Subject to the rules and regulations prescribed under this Act, an implementing agency may enter into a negotiated procurement of a project in case the Federal Government authorizes such an exception, for reasons to be recorded in writing, in the public interest.

The PPP Act is silent on the PPP lifecycle and processes. The PPPA Amendment Act 2021, however, indicates that the provisions of the Act shall supersede other extant Acts, and authorizes the implementing agencies to seek private sector participation in appropriate projects. The Act also indicates that appropriate rules and regulations will be formulated under the Act to facilitate the entrance of implementing agencies into contracts with the private sector players. Subsequently, the process flow for approvals and for bidding and contract award shall be prescribed. The Act also includes a new chapter on the legal and contractual framework for PPPs.

On the other hand, the PPP Policy of 2010 and the Project Preparation/Feasibility Guidelines for PPP Projects of 2007 could be considered as basis for the project preparatory activities for PPPs. Figure 9 provides a snapshot of the PPP lifecycle and the project process from inception to exit stage.

Figure 9: Public-Private Partnership Life Cycle and Processes in Pakistan

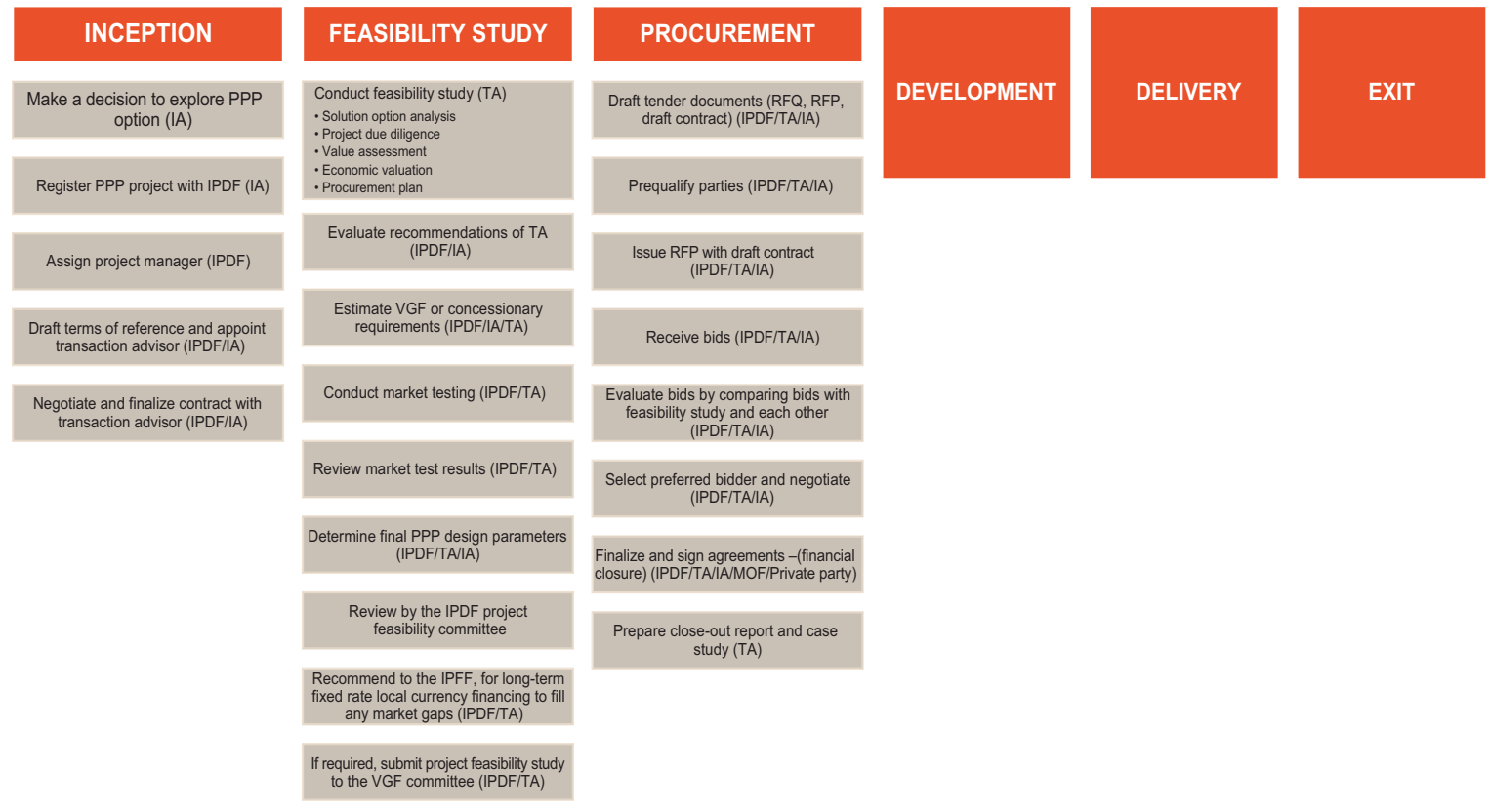

IA = implementing agency, IPDF = Infrastructure Project Development Facility (now Public Private Partnership Authority or P3A), IPFF = Infrastructure Project Finance Facility, MOF = Ministry of Finance, PPP = public-private partnership, $\mathrm{RFP}=$ request for proposal, $\mathrm{RFQ}=$ request for qualification, $\mathrm{TA}=$ transaction advisor, VGF = viability gap funding. Source: Government of Pakistan, Ministry of Finance, and IPDF. 2007. Project Preparation/Feasibility Guidelines for PPP Projects. Islamabad. 
The Provincial Procurement Regulatory Authority Acts and Rules and the PPP Acts of the provinces control the PPP procurement functions in the provincial governments of Sindh and Punjab. Federal legislation is not fully aligned with the PPP procurement processes throughout the provinces of Pakistan. The federal PPRA Rules do not provide any framework for PPP procurements in the country. There is a need to align procurement laws and procedures at the federal and provincial levels to enable greater private sector participation and competition, and to create an aligned environment for PPPs across provincial boundaries (footnote 5). Table 5 describes the PPP procurement processes in Pakistan.

\section{Table 5: Public-Private Partnership Procurement Process in Pakistan}

\begin{tabular}{|c|c|}
\hline Theme & Description \\
\hline $\begin{array}{l}\text { Responsible } \\
\text { agency }\end{array}$ & $\begin{array}{l}\text { Line ministries, federal bodies, provincial and local authorities, and state-owned enterprises are the } \\
\text { contracting parties on behalf of the federal government with private parties. They will therefore be } \\
\text { responsible, mainly or in conjunction with other bodies, for the identification, selection, sponsorship, } \\
\text { preparation, tendering, and monitoring of public-private partnership (PPP) projects in their sectors. The } \\
\text { line ministries that want to promote PPPs will prepare model concession agreements for that particular } \\
\text { sector. Strong support for the line ministries is available from institutions such as the Public Private } \\
\text { Partnership Authority, the Ministry of Finance, and the Planning Commission. }\end{array}$ \\
\hline $\begin{array}{l}\text { Project } \\
\text { inception }\end{array}$ & $\begin{array}{l}\text { - A decision is made to explore the PPP for the development of a project. } \\
\text { - Potential PPP projects are identified from master plan or through preliminary needs analysis. } \\
\text { - } \text { - A decision is made on the option to pursue the project. } \\
\text { - The project is registered with the PPP Cell/Unit. } \\
\text { - The technical and financial proposals are evaluated. }\end{array}$ \\
\hline $\begin{array}{l}\text { Project } \\
\text { preparation }\end{array}$ & $\begin{array}{l}\text { - Feasibility studies are carried out and their conclusions and recommendations are reviewed. } \\
\text { - A decision is made on whether to proceed with the project any further, or to reject or send back for } \\
\text { reconsideration the project proposal. }\end{array}$ \\
\hline $\begin{array}{l}\text { Transaction } \\
\text { execution }\end{array}$ & $\begin{array}{l}\text { - An information memorandum is prepared for project marketing. } \\
\text { - Market sounding of potential investors and lenders is conducted. } \\
\text { - Project structure and tender documents are finalized. } \\
\text { two-stage process of prequalification and bidding. } \\
\text { - A request for prequalification applications is issued. A notice is published inviting private companies } \\
\text { and consortia of such companies to submit prequalification applications, based on appropriate } \\
\text { predefined criteria such as legal requirements and technical and financial capability. } \\
\text { - Prequalification applications are evaluated to determine which among the companies and consortia } \\
\text { meet these criteria. } \\
\text { - After prospective private partners have been prequalified, an invitation will be issued for these private } \\
\text { parties to submit bids. } \\
\text { - A pre-bid conference will be conducted to clarify the terms and conditions of the draft PPP } \\
\text { - Received bids are evaluated. Bid evaluation will be carried out in two phases. First, the technical, } \\
\text { operational, environmental, and commercial soundness of the bids received will be assessed through } \\
\text { the requirements, criteria, and minimum standards specified in the tender documents. Noncompliant } \\
\text { bids will be rejected. The responsive bids will be evaluated in the second phase from the financial } \\
\text { viewpoint. The evaluation will be based on a parameter specified in the tender documents, which is } \\
\text { also dependent on the type of the PPP project. } \\
\text { Depending on the number of bids received, the procuring authority may need to restructure the } \\
\text { project and re-bid if too few bids are received. Alternatively, if the required number of private bidders } \\
\text { submit bids, a recommendation is made on the contract award to the approving authority. } \\
\text { - The awarding authority will decide on whether to approve or send back for reconsideration the } \\
\text { contract award recommendation. }\end{array}$ \\
\hline
\end{tabular}


Table 5 continued

\begin{tabular}{|c|c|}
\hline Theme & Description \\
\hline & $\begin{array}{l}\text { - Results of the bidding process are announced, and a notice of award is issued to the selected private } \\
\text { partner. } \\
\text { - Negotiations are conducted with the preferred bidder. These negotiations focus on terms and } \\
\text { conditions not directly specified in the tender documentation. } \\
\text { - The PPP agreement is signed. } \\
\text { - The conditions precedent to financial closure are fulfilled. The private partner will endeavor to } \\
\text { achieve financial closure within the predetermined period specified in the tender documentation. } \\
\text { The period to achieve financial closure from signing of the PPP agreement should not be more than } \\
12 \text { months. }\end{array}$ \\
\hline $\begin{array}{l}\text { Construction, } \\
\text { operation, and } \\
\text { transfer }\end{array}$ & $\begin{array}{l}\text { - Project implementation is monitored to ensure conformity with plans and specifications. } \\
\text { - Project operation is monitored and evaluated to ensure conformity with performance standards and } \\
\text { - Financial performance of the project is monitored and evaluated. } \\
\text { - Arrangements are made for the project transfer to the government at the end of the term of the PPP } \\
\text { agreement. }\end{array}$ \\
\hline
\end{tabular}

Source: Asian Development Bank. 2019. Public-Private Partnership Monitor. Second Edition. Manila. https://www.adb.org/sites/default/ files/publication/509426/ppp-monitor-second-edition.pdf.

\section{Public-Private Partnership Standard Operating Procedures, Toolkits, Templates, and Model Bid Documents}

\section{Parameter}

Does the country have public-private partnership (PPP) guidelines/PPP guidance manual?

Does the PPP guidelines/PPP guidance manual adequately cover the process, entities involved, roles and responsibilities of various entities, approvals required at various stages, and the timelines for the various stages of the PPP project life cycle?

What are the templates and checklists available in the PPP guidelines/PPP guidance manual?

- Project needs assessment and options analysis checklist?

- Project due diligence checklist?

- Technical assessment checklist?

- Environmental assessment checklist?

- PPP procurement plan template?

Does the country have standardized/model bidding documents for PPPs?

- Model request for qualification document?

- Model request for proposal document?

- Model PPP/concession agreement?

- State support agreement?

- Viability gap funding agreement?

- Guarantee agreement?

- Power purchase agreement?

- Capacity take-or-pay contract?

- Fuel supply agreement?

- Transmission and use of system agreement?

- Performance-based operations and maintenance contract?

- Engineering, procurement, and construction contract?

Does the country have standardized PPP agreement terms for the following? 
continued from previous page

\section{Parameter}

Does the country have standardized/model toolkits to facilitate identification, preparation, procurement, and management of PPP projects?

- PPP family indicator?

- PPP mode validity indicator?

- PPP suitability filter?

- PPP screening tool?

- Financial viability indicator model?

- Economic viability indicator model?

- Value-for-money indicator tool?

- Readiness filter?

Is there a framework for monitoring fiscal risks from PPPs?

- Process for assessing fiscal commitments?

- Process for approving fiscal commitments?

- Process for monitoring fiscal commitments?

- Process for reporting fiscal commitments?

- Process for budgeting fiscal commitments?

Are there fiscal prudence norms/thresholds to limit fiscal exposure to PPPs?

Is there a process for assessing and budgeting contingent liabilities from PPPs?

$\checkmark=$ Yes, $x=$ No.

a Article 12A of the Public Private Partnership Authority (PPPA) Amendment Act 2021 assigns the responsibility of reviewing and managing fiscal risks in PPP projects to the Risk Management Unit. The Article states that the responsibility for fiscal oversight and for evaluation of fiscal and contingent liability exposure for all qualified projects shall lie with the Risk Management Unit. Such evaluation shall be determined by the Finance Division in consultation with the PPPA.

At the federal level, the Government of Pakistan issued the Project Preparation/Feasibility Guidelines for PPP Projects in August 2007 and the Policy on Public-Private Partnerships in January 2010.

\section{Key Clauses Related to Public-Private Partnership Agreement}

The PPPA Amendment Act 2021 prescribes that every agreement shall be governed, construed, and interpreted in accordance with the laws of Pakistan and shall include the following key clauses (footnote 6):

(i) scope of activities of the parties to the agreement;

(ii) duration of the agreement;

(iii) payment arrangements for the private party, including, where applicable, the factors based on which and the manner in which user charges or tariffs may be revised;

(iv) rights and obligations of the parties and the respective risks to be borne by each party;

(v) penalties for noncompliance with the provisions of the PPP agreement;

(vi) dispute resolution mechanisms;

(vii) exit clauses specifying the procedure of early termination of the PPP agreement;

(viii) termination payments and compensations, if agreed and provided in the PPP agreement;

(ix) debt-equity ratio;

(x) monitoring;

(xi) project insurances and treatment of insurance proceeds;

(xii) O\&M requirements; and

(xiii) reversion, transfer, or handing back of the project, wherever applicable, and all the associated assets to the implementing agency upon expiry or termination of the PPP agreement. 
Implementation or Concession Agreement. The implementation agreement is the agreement signed between the federal government and the project company under which the federal government provides certain undertakings to the project (with respect to, for example, support to obtain consents and permits, taxation and import control undertakings, and undertakings with respect to foreign exchange and the availability of funds in Pakistan). The federal government also provides protection to sponsors and lenders in case of termination of the project agreements under specific circumstances. A sovereign guarantee is issued pursuant to the implementation agreement where the federal government guarantees the payment obligations of the power purchaser and the federal government (footnote 5).

Energy/Power Purchase Agreement. The energy/power purchase agreement (EPPA) or the power purchase agreement (PPA) is the agreement signed between the power purchaser and the project company under which the power purchaser buys the output from the project company and then sells the output in the market. The EPPA/ PPA sets out the terms and conditions on which the power purchaser buys the output and/or capacity (as the case may be) from the project company. For the bankability of the project, the project company determines whether enough revenue will be generated from the project to service debt and make a profit to be distributed as dividends. The revenue generated from the EPPA/PPA is used to pay for, among other things, the operating expenses, debt servicing, and procuring fuel (in case of nonrenewable projects). The EPPA/PPA further provides protection to investors and lenders against specific political risks, and against changes in the tax and duty regime. Given a suitable indexation of tariff components, the EPPA/PPA covers the risk of losses due to exchange rate variations and inflation. Such protection, however, should be based on applicable tariffs (footnote 5).

Capacity Take-or-Pay Contract. The capacity take-or-pay contracts require the power purchaser to make payments to the project company for making the output available, regardless of whether the output is off-taken or not. These contracts apply to nonrenewable projects. For renewable projects, the off-take requires to purchase all outputs of the companies (footnote 5 ).

Fuel Supply Agreements. The fuel supply agreement is the agreement signed between the project company and the fuel supplier for the sale and purchase of fuel that is necessary to operate the project. The fuel supply agreement sets out the terms and conditions of the sale and purchase of fuel. The fuel supply agreement is usually back-toback with the PPA as the dispatch instructions are required for fuel ordering under this agreement. Performance obligations of the fuel supplier are no longer guaranteed by the federal government (footnote 5).

Performance-based Operation and Maintenance Contract. After completion of the construction of the works, a project company usually requires experts to operate and maintain the project during the concession period. An O\&M contract therefore involves managing the operations of the project, providing maintenance of the complex, and running it as per the requirements of the system operator and based on the dispatch instructions of the power purchaser. Where the project does not operate on the thresholds required by the power purchaser, the power purchaser, in some instances, can withhold payments or collect damages (footnote 5).

Engineering, Procurement, and Construction Contract. Even though the standard documentation for engineering, procurement, and construction (EPC) contracts are not International Federation of Consulting Engineers (FIDIC) based, guidance is still derived from the FIDIC formats. Once financing has been arranged for the project by the project company, lenders usually require an EPC contract in place to commence construction works soon after the financial closure of the project. The project company enters into an EPC contract with a construction contractor who undertakes engineering, design, and construction of the project within certain timelines for the project to be functional by the time the power purchaser or federal government requires it to be functional. The project company requires the construction contract to provide warranties of the equipment installed, procure the necessary licenses and approvals for commissioning of the complex, complete the construction on time, and ensure functionality and performance of the completed works (footnote 5). 


\section{Other Critical Contractual Provisions and Public-Private Partnership Enabling Considerations}

\begin{tabular}{|l|c|}
\hline Parameter & \\
\hline Does the law specifically enable lenders the following rights: & $\checkmark$ \\
\hline - Security over the project assets & $\checkmark$ \\
\hline - Security over the land on which they are built (land use right) & $\checkmark$ \\
\hline - Security over the shares of a public-private partnership project company & $\checkmark$ \\
\hline - Can there be a direct agreement between the government and lenders? & $\checkmark$ \\
\hline - Can lenders be given step-in rights? & $\checkmark$ \\
\hline
\end{tabular}

\section{$\checkmark=$ Yes}

Source: Asian Development Bank. 2019. Public-Private Partnership Monitor. Second Edition. Manila. https://www.adb.org/sites/default/ files/publication/509426/ppp-monitor-second-edition.pdf.

In securing loans for projects, the laws of Pakistan allow project companies to procure loans from both local and foreign banks and financial institutions. The primary legislations dealing with investment matters are the Investment Policy, the Reforms Act, the Foreign Exchange Regulation Act 1947, the Foreign Exchange Manual, and various notifications and circulars issued by the State Bank of Pakistan (SBP) from time to time pertaining to foreign exchange (footnote 5).

Section 13 (1) (b) of the Foreign Exchange Regulation Act prohibits transfer of any security, or creation or transfer of any interest in a security to or in favor of a nonresident, except with the general or special permission of the SBP. General permissions are those that are already contained in the Foreign Exchange Manual. Where the Foreign Exchange Manual does not provide general permission, special permission of the SBP has to be sought (footnote 5).

\section{Security over the project assets}

In Pakistan, security may be created over the company's project assets through hypothecation in favor of lenders. The project company may also enter into a Letter of Lien and Set-Off, which usually applies to the project accounts of the company (footnote 5).

\section{Security over the land on which they are built (Land Use Right)}

Security over the company's immovable assets (land) is generally created in the form of an equitable mortgage by deposit of land title deeds to avoid levying of a significant amount of duty. The security instrument is a Memorandum of Deposit of Title Deeds, which confirms the creation of the security over the shares of a PPP project company (footnote 5).

A pledge on the shares of the project company may be created in favor of lenders through physical transfer of possession of the original share certificates (usually accompanied with blank transfer deeds). The company and lenders enter into a share pledge agreement to confirm the creation of the security. In case of foreign financing, the pledge is not enforceable until consent is procured from the SBP (footnote 5). 
After the introduction of the Companies Act, the pledge on shares has become registrable. Enforcement of share pledge should be considered in the context of the type of company (i.e., public unlisted or private) since the rights in relation to each vary (footnote 5 ).

\section{Can there be a direct agreement between the government and the lenders?}

Generally, direct agreements are acceptable forms of security. They are often included in project finance transactions executed in Pakistan. They also apply to PPP projects (footnote 5).

\section{Do lenders get a priority in case of insolvency?}

Lenders do get a priority in case of insolvency to the extent of the registration of their charges against the borrower's assets. Such charge registration is perfected through filling out Form 10. The Securities and Exchange Commission of Pakistan then issues a charge certificate acknowledging the security perfection. Therefore, if the lenders have perfected a first ranking charge, they will get a priority in case of insolvency. However, before such priority can be exercised by the lenders, in case of insolvency, any outstanding amounts to the government in the form of taxes, utility bills, or land dues are deducted first (footnote 5).

\section{Can lenders be given step-in rights?}

Step-in rights are given to lenders through direct agreements. This is a well-established practice. Under the standard concession agreements for the power sector, the counterparty is restricted from terminating such concession agreements without first giving a copy of any notice required to be given to the project company and to the lenders. The lenders are entitled to cure or procure the cure of any defaults of the project company within the cure period allowed. Lenders are also allowed to assume operations of the facilities and granted extended cure periods to remedy the project company's defaults (footnote 5).

\section{Parameter}

Does the law specifically enable compensation payment to the private partner in case of early termination due to:

- Public sector default or termination for reasons of public interest

- Private sector default

- Force majeure

Does the law enable the concept of economic/financial equilibrium?

Does the law enable compensation payment to the private partner due to:

- Material adverse government action

- Force majeure

- Change in law

$\checkmark=$ Yes, $x=$ No.

a There is no specific provision on material adverse government action in the Act; however, there is no prohibition on the same either. It may be inferred that the PPP Authority could include it based on the context.

Source: Asian Development Bank. 2019. Public-Private Partnership Monitor. Second Edition. Manila. https://www.adb.org/sites/default/ files/publication/509426/ppp-monitor-second-edition.pdf. 


\section{Public sector default or termination for reasons of public interest}

The law is not restrictive on the provision of compensation payments to the private partner in case of early termination, and such compensation payments are covered as a contractual matter under projects. Under the standard power concession agreements, the occurrence of an event of default on the part of the public partner - unless caused in whole or material part by a breach of the project company under the respective agreements, and unless such events occur as a result of a force majeure event-enables compensation payments to be paid to the private partner (footnote 5).

\section{Private sector default}

In the case of an early termination due to the project company's default, compensation payments are made to the extent contractually decided (footnote 5 ).

\section{Force majeure}

The law does not restrict payment of compensation due to termination on the occurrence of force majeure events. The concept is most prevalent under the power sector; but even in other sectors, compensation payments are allowed in the event of termination due to the occurrence of force majeure events to safeguard the private partner against political change or disruptions, changes in law, and other external events beyond the control of either party. In either scenario, depending on the contractual arrangement between parties, the public partner often makes compensation payments for termination in such events (footnote 5).

\section{Does the law enable the concept of economic and/or financial equilibrium?}

As per Section 31 (2) of the Regulation of Generation, Transmission and Distribution of Electric Power Act 1997 (NEPRA Act), the law requires the National Electric Power Regulatory Authority (NEPRA) to issue a tariff determination keeping in view "the protection of consumers against monopolistic and oligopolistic prices, economic efficiency in the electric power industry, and elimination of exploitation and minimization of economic distortions." Pursuant to Section 31 (3) of the NEPRA Act, the law also subjects NEPRA to the following guidelines (footnote 5):

- tariffs should allow licensees the recovery of any and all cost prudently incurred to meet the demonstrated needs of their customers; and

- tariff should allow licensees a rate of return, which promotes continued reasonable investment.

\section{Does the law enable compensation payment to the private partner due to force majeure or change in law?}

The law specifically does not restrict payment of compensation to the private partner due to a force majeure event or a change in law. These are subjects that are covered under the contractual arrangements between the private and the public partners. However, to safeguard the interests of the investors, the public partner covers the risk of force majeure events and changes in law. Such contractual provisions are most prominent under the power sector but, at present, are also prevalent in other sectors (footnote 5). 


\title{
7. Unsolicited Public-Private Partnership Proposals
}

\author{
Parameter \\ Does the public-private partnership legal and regulatory framework allow submission and acceptance of \\ unsolicited proposals? \\ What are the advantages provided to the project proponent for an unsolicited bid? \\ - Competitive advantage at bid evaluation? \\ - Swiss challenge? \\ - Compensation of the project development costs? \\ - Government support for land acquisition and resettlement cost? \\ - Government support in the form of viability gap funding and guarantees? \\ $\checkmark=$ Yes, $x=$ No \\ a Not expressly prohibited by law. \\ Source: Asian Development Bank. 2019. Public-Private Partnership Monitor. Second Edition. Manila. https://www.adb.org/sites/default/ \\ files/publication/509426/ppp-monitor-second-edition.pdf.
}

The Public Private Partnership Authority (PPPA) Amendment Act 2021 reiterates that unsolicited proposals could be considered for further evaluation. Further details including those related to procedures to evaluate and reward a private sector player may be provided in the subsequent issuance of rules and regulations. The newly introduced Section 14A of the PPP Act states,

A private party may submit proposal for a project on an unsolicited basis to the authority or an implementing agency in the manner in meeting such requirements as prescribed, which shall be subject to procurement procedures prescribed from time to time.

Although unsolicited proposals are not expressly prohibited in Pakistan under the Federal PPP Law, they are not preferred by the federal government due to potential issues relating to lack of transparency and unequal treatment of bidders. Some provinces (e.g., Sindh and Punjab) have adopted their own practices when dealing with an unsolicited proposal. With regard to project development cost, in the province of Punjab, for example, the project proponent shall be reimbursed costs for preparing and submitting an unsolicited proposal. In the event the proponent fails to be adjudged as the best evaluated bidder, the cost of preparation of the unsolicited proposal shall be determined by the government authority. There is no such reference found with regard to the treatment of project development cost under Federal PPP Laws (footnote 5). Also, under the Sindh PPP framework, after the provincial government of Sindh approved the unsolicited proposal, a Swiss Challenge process will be followed through a two-step procedure (prequalification and tender). The unsolicited proposal proponent will be exempt from the prequalification requirement and will gain a $5 \%$ additional weightage in the combined score of the technical and financial evaluation, as well as a right of first refusal (or a right to match)..1

Various considerations are applicable with respect to unsolicited proposals, including being able to demonstrate innovation, reasoned analysis, a match to the requirements of the country, and the project's likely inability to be procured through an alternative method. The federal government may decide whether unsolicited proposals would require competitive bidding during the project procurement. The provincial framework allows for certain benefits to be awarded to the proponent of the unsolicited proposal during the competitive bidding process. These include exemption from prequalification, additional weightage of points during the evaluation process, and a right of first refusal (footnote 5).

11 ADB Pakistan Resident Mission; ADB Office of Public-Private Partnership 
The Pakistan policy on PPPs highlights the process for unsolicited proposals (footnote 5):

- The private sector identifies a potential project.

- The private sector seeks guidance from the federal government on the framework for unsolicited bids and discusses this project with the authority to ensure that it is suitable for consideration.

- A private sector entity prepares its own feasibility study of the proposal.

- A private sector entity submits study and proposal to the federal government.

- The federal government appraises project and accepts project; or requires more information on, or changes to, the project; or rejects bid outright due to various conditions not met.

- The federal government proceeds or not, according to its rules and regulations.

\section{Foreign Investor Participation Restrictions}

\begin{tabular}{|l|c|}
\hline Parameter & \\
\hline Is there any restriction for foreign investors on: & $\times$ \\
\hline - Land use/ownership rights as opposed to similar rights of local investors & $\times$ \\
\hline - Currency conversion & 54 \\
\hline Public-private partnership projects with foreign sponsor participation (no.) & \\
\hline
\end{tabular}

$x=$ No

As per the Pakistan Investment Policy 2013 (Investment Policy), all sectors and activities are open for foreign investment unless specifically prohibited or restricted for reasons of national security and public safety. Specified restricted industries include arms and ammunitions; high explosives; radioactive substances; securities, currency, and mint; and consumable alcohol. There is no upper limit on the share of foreign equity allowed, except in specific sectors including airline, banking, agriculture, and media. For corporate agriculture farming, foreign investors are allowed to hold $100 \%$ equity (footnote 5 ).

Foreign investors are restricted from holding Pakistani securities without the prior general or special permission of the SBP. Under the Foreign Exchange Manual 2017, the SBP has granted general permission or exemption to foreign nationals and firms (including partnerships), trusts, and mutual funds registered outside Pakistan, subject to certain conditions. There are no restrictions on the purchase price paid to a nonresident shareholder already holding Pakistani securities in accordance with the general or special permission of the SBP. However, such general permission is not available for entities owned or controlled by a foreign government, which require the prior written permission of the SBP (footnote 5).

Foreigners holding Pakistani securities in accordance with the general or special permission of the SBP are entitled to repatriation of dividends and disinvestment proceeds net of Pakistan tax liability. Remittance of disinvestment proceeds exceeding the break-up value of the shares, as certified by a practicing, chartered accountant in Pakistan, requires the prior written permission of the SBP (footnote 5).

Pursuant to the Foreigner Act, the federal government has ordered that no foreigner shall, directly or indirectly, acquire land or any interest in land or landed property in Pakistan, except with the previous permission of the federal government or of the provincial government. Permission from the federal government or respective provincial government may be granted on a routine basis as part of the approval process for the relevant PPP project. By way of 
established practice, the above restriction has not been applied to ownership of land by companies incorporated in Pakistan, even where such companies are owned or controlled by foreign investors (footnote 5).

\section{Dispute Resolution}

\begin{tabular}{|l|c|}
\hline Parameter & $x$ \\
\hline Does the country have a dispute resolution tribunal? & $\times$ \\
\hline Does the country have an institutional arbitration mechanism? & $\checkmark$ \\
\hline Can a foreign law be chosen to govern public-private partnership (PPP) contracts? & $\checkmark$ \\
\hline What dispute resolution mechanisms are available for PPP agreements? & $\checkmark$ \\
\hline - Court litigation & $\checkmark$ \\
\hline - International arbitration & $\checkmark$ \\
\hline Has the country signed the New York Convention on the Recognition and Enforcement of Foreign Arbitral & \\
\hline
\end{tabular}

$\checkmark=$ Yes, $x=$ No.

Source: Asian Development Bank. 2019. Public-Private Partnership Monitor. Second Edition. Manila. https://www.adb.org/sites/default/ files/publication/509426/ppp-monitor-second-edition.pdf.

Pakistan has no dispute resolution tribunal nor an institutional arbitration mechanism. It all depends on the arbitration clauses in the agreement. Article 18 of the PPPA Amendment Act 2021 relates to the settlement of disputes. The PPPA Amendment Act 2021 stipulates the provision of the PPP agreement for resolution of disputes between the parties. It also prescribes that the federal government require the private party to exhaust all domestic dispute resolution remedies including recourse to domestic courts before seeking international arbitration. The Act provides the parties an option to refer the dispute to the PPPA for settlement through mediation (footnote 6).

As to foreign jurisdiction clauses, the courts in Pakistan have held that these clauses are valid under Pakistan law. However, the jurisdiction provision will not be construed as ousting the jurisdiction of Pakistan's courts but will be dealt with in the same manner as an arbitration clause in the event of legal proceedings being instituted in a court in Pakistan. Accordingly, in the event that any legal proceedings are instituted by a party in Pakistan, even when the contract is governed by the laws of a foreign country, the other party against whom the legal proceedings have been instituted can apply for stay of the proceedings in terms of section 34 of the Pakistan Arbitration Act 1940 (footnote 5).

\section{Arbitration}

There are two major statutory instruments that govern arbitration in Pakistan: the Arbitration Act 1940, which applies to local arbitrations, and the Recognition and Enforcement (Arbitration Agreements and Foreign Arbitral Awards) Act 2011, which applies to foreign arbitrations. Neither of these are based on the United Nations Commission on International Trade Law Model Law. ${ }^{12}$

12 RIAA Barker Gillette. 2020. In Brief: Arbitration Formalities in Pakistan. Lexology. 16 June. https://www.lexology.com/library/detail.aspx?g=04064317ff25-4a12-945c-5belbd761f25. 
The Arbitration Act 1940 (the 1940 Act) is applicable to all local arbitration and provides for three approaches to arbitration (footnote 12):

- without the intervention of the court;

- with the intervention of the court; and

- with the intervention of the court but where a suit is pending between the parties and they agree for the resolution of their disputes through arbitration, keeping the suit pending and that the fate thereof (suit) be decided on the basis of the decision rendered by the arbitrator.

The Recognition and Enforcement (Arbitration Agreements and Foreign Arbitral Awards) Act 2011 (the 2011 Act) has been enacted to implement the Convention on the Recognition and Enforcement of Foreign Arbitral Awards or the New York Convention, which Pakistan has ratified (footnote 12).

Pakistan is a contracting state to the New York Convention on the Recognition and Enforcement of Foreign Arbitral Awards (the New York Convention). Pakistan became a signatory to the Convention on 30 December 1958 and it was ratified on 14 July $2005 .^{13}$

The New York Convention was first implemented under the Recognition and Enforcement (Arbitration Agreements and Foreign Arbitral Awards) Ordinance 2005, which was subsequently re-promulgated from time to time (Foreign Arbitration Ordinances), before it was enacted as the Recognition and Enforcement (Arbitration Agreements and Foreign Arbitral Awards) Act 2011 on 19 July 2011 (Foreign Arbitration Act). The Foreign Arbitration Ordinances, which are promulgated from time to time, and the Foreign Arbitration Act are substantially identical. In terms of Article $V$ of the New York Convention, a foreign arbitral award will not be enforced where recognition and enforcement of the same would be contrary to the public policy of Pakistan. The term "public policy" is not defined in the Foreign Arbitration Act nor in judicial pronouncements related to the enforcement of foreign arbitral awards. Hence, the meaning ascribed to "public policy" in Section 23 of the Contract Act 1872 has been interpreted by the courts in this context. The international arbitration framework alternative dispute resolution centers, as indicated above, have recently been established in Pakistan. Judicial processes on the dispute should not be initiated by the relevant parties unless all other remedies in the PPP agreement have been exhausted (footnote 13).

\section{Environmental and Social Issues}

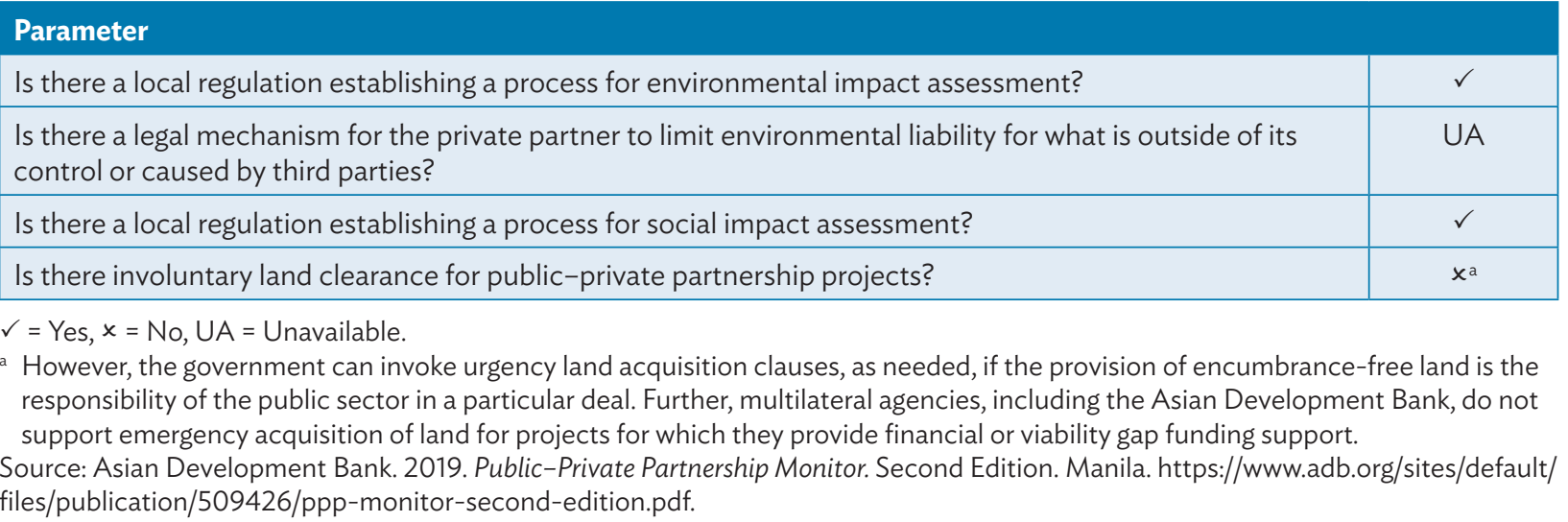

13 Bhandari Naqvi Riaz. 2020. First-Step Analysis: Arbitration in Pakistan. Lexology. 24 February. https://www.lexology.com/library/detail. aspx?g=fb17baa0-25f4-4416-aele-32fadc655bda. 


\section{Local Regulation for Initial Environmental Examination and Environmental Impact Assessment}

The Pakistan Environmental Protection Act 1997 (PEPA) is the principal environmental legislation in the country. In all four provinces and at the federal level, environmental protection agencies were established under the provision of the PEPA (footnote 5).

The environmental protection agencies carry out initial environmental examination (IEE) and environmental impact assessment (EIA) in their respective jurisdictions. The environmental protection agencies are as follows (footnote 5 ):

- Pakistan Environmental Protection Agency,

- Punjab Environmental Protection Agency,

- Sindh Environmental Protection Agency,

- Khyber Pakhtunkhwa Environmental Protection Agency, and

- Balochistan Environmental Protection Agency.

At the federal level and for the provinces of Punjab, Khyber Pakhtunkhwa, and Balochistan, the process of applying for and obtaining the IEE and the EIA is regulated under the Pakistan Environmental Protection Agency (Review of IEE and EIA) Regulations 2000 (IEE and EIA Regulations). A brief summary regarding the requirements for IEE and EIA approvals is as follows:

\section{- Initial Environmental Examination}

Under the PEPA and concurring provincial laws, no proponent of a project can commence construction or operation unless

- the proponent has filed an IEE with the relevant environmental protection agency; or

- where the project is likely to cause an adverse environmental effect, an EIA has been conducted and the project has been approved.

An IEE essentially involves a preliminary environmental review of the reasonably foreseeable qualitative and quantitative impacts on the environment of a proposed project. It aims to determine whether the project is likely to cause an "adverse environmental effect" for requiring preparation of an EIA.

\section{- Environmental Impact Assessment Approvals}

An EIA requires an environmental study comprising collection of data; prediction of qualitative and quantitative impacts; comparison of alternatives; evaluation of preventive, mitigatory, and compensatory measures; formulation of environmental management and training plans and monitoring arrangements; framing of recommendations; and other components as may be prescribed by rules.

Upon receipt of the EIA approval from the relevant environmental protection agency and before commencing construction of the project, the proponent is required to provide an undertaking acknowledging acceptance of the terms of the EIA approval. Thereafter and prior to operation of the project, the proponent has to submit an environmental management plan and request for a confirmation from the relevant environmental protection agency of compliance to the conditions of the EIA approval. Upon receipt of such confirmation, the project company can commence operations (footnote 5). 
In the Province of Sindh, IEE and EIA approvals are regulated under the Sindh Environmental Protection Agency (Review of Initial Environmental Examination and Environmental Impact Assessment) Regulations 2014 (Sindh IEE and EIA Regulations). However, the requirements in the Sindh IEE and EIA Regulations mirror the requirements of the IEE and EIA Regulations, as summarized above (footnote 5).

\section{Local Regulation for Social Impact Assessments}

There is no local regulation for social impact assessments (SIAs) in Pakistan. In the province of Punjab, however, to assess the social consequences of PPP projects, guidelines have been issued by the Public Private Partnership Cell, Planning and Development Department, the provincial government of Punjab (collectively referred to as Punjab SIA Guidelines) (footnote 5).

Under the Punjab SIA Guidelines, SIAs can be undertaken as part of an environmental assessment process, or independently, if required, to better assess the social consequences, both positive and negative, of implementing a PPP project. However, no process has been defined for PPPs to conduct SIA and neither has a regulator been identified for carrying out the SIA (footnote 5).

Other than Punjab, in all other provinces and at the federal level, no such guidelines have been developed. However, it has been observed that both Sindh and Punjab apply the Environmental and Social Management System when implementing PPP projects (footnote 5).

\section{Land Rights}

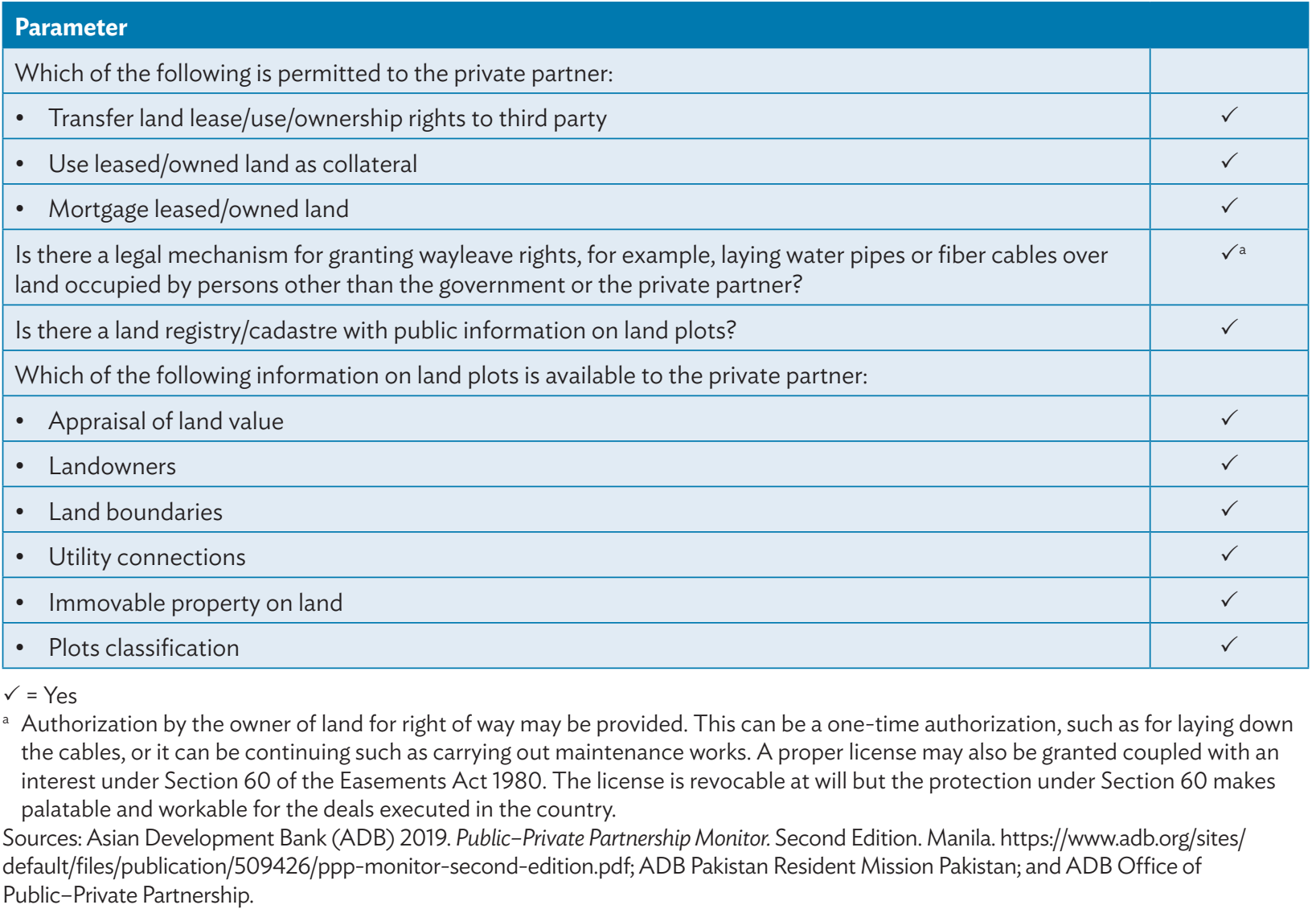


The numerous land laws in Pakistan are central to the PPP transaction and are relevant for local and foreign users or owners of land. In regard to PPP arrangements in Pakistan involving a contractual arrangement between public (national, state, provincial, or local) and private entities, this section focuses on the various rights pertaining to land (footnote 5).

The key regulations governing land in Pakistan are as follows (footnote 5):

- The Transfer of Property Act 1882,

- The Land Acquisition Act 1894,

- The Registration Act 1908,

- The Stamp Act 1899,

- The Easements Act 1882,

- Punjab Land Records Authority Act 2017,

- The Colonization of Government Lands (Punjab) Act 1912,

- The Colonization of Government Lands Act 1912 (in its application to the province of Sindh), and

- The Land Revenue Act 1967.

Various portions of land in Pakistan belong to the state. State-owned land in Pakistan may be leased, granted, or assigned to individuals or corporations for various purposes. In most cases where state land is used by nonstate entities, the land remains in the possession of the state with rent payable from the tenants to the state, such as in a leasing arrangement where such land is leased out to private developers on the terms stipulated in the lease. The regulatory environment in Pakistan provides the procuring authority the ability to make available the necessary land or right-of-way to PPP project companies for the development of PPP projects (footnote 5).

The rights, terms, and conditions pertaining to land are determined on a case-to-case basis. The land acquisition options include the following:

- An acquisition of the land by the provincial government (whether voluntary or compulsory)—the land being sold or leased thereafter to the private developer

Where the provincial government acquires land, pursuant to the Land Acquisition Act, in any locality that is likely to be needed for public purpose or for a company, it shall require the company to enter into an agreement with the provincial government. The land can only be utilized for the purposes specified in the agreement with the provincial government for the purchase of land. Section 43-A of the Land Acquisition Act provides that no company for which any land is acquired shall be entitled to transfer the said land or any part thereof by sale, mortgage, gift, lease, or otherwise except with the previous sanction of the provincial government.

Furthermore, in case a private partner, being a tenant under the Colonization of Government Lands Act (CGLA), holding land in an area owned by the provincial government of Punjab, shall not, pursuant to Section 19 of the CGLA, transfer or charge by sale exchange, gift, will, mortgage, or other private contract of any form, other than a sublease, any rights or interests vesting in the tenant under the CGLA, without the consent in writing of the commissioner appointed by the Board of Revenue of the Revenue Department of Government of Punjab.

For the purposes of using leased and/or owned land as collateral, the right to use land to create a security varies in terms of the PPP laws in the respective provinces. 
At the federal level, the private party shall not create any lien, charge, or encumbrance, in favor of the lenders, over the immovable properties as collateral, except with the prior approval of the board of the Federal PPP Authority. The financing of a PPP project in other provinces is dependent upon the terms and conditions determined by the parties to the PPP agreement, or may be subject to any restriction that may be contained in the concession contract to create security interests over any of its assets, rights, or interests, including those relating to the infrastructure project to secure any financing for the project (footnote 5).

\section{- Voluntary acquisition of the land by the private developer or partner}

A private developer can freely acquire land through sale and/or purchase and the immovable property can be transferred to a purchaser via a registered instrument.

In case the land is privately acquired for the project, then, subject to the municipal and other regulatory restrictions or consents pertaining to a PPP project, the owner of the land is free to utilize and transfer the land as it wishes. Where the land is leased, then, such land would be subject to the terms specified in the lease agreement. The land can be used for a specific term which would be specified in the lease agreement. The term of the lease should ideally match the life of the project.

The Transfer of Property Act (TPA) allows for the creation of a charge over immovable property-where either by the act of the parties to the PPP arrangement or by operation of law whereby the immovable property is made as a security for the payment of money to another, and the transaction does not amount to a mortgage.

Moreover, a company may mortgage its acquired land through a mortgage deed. Mortgages, under the TPA, can be made of a specific immovable property for the purpose of securing the payment of money in advance or to be advanced by way of loan, an existing or future debt, or the performance of an engagement which may give rise to a pecuniary liability (footnote 5).

\section{Acquisition of Land by a Foreigner}

In relation to the ownership of land, the federal government in exercise of its powers, under the Foreigner Act 1946, has ordered that no foreigner shall, directly or indirectly, acquire land or any interest in land or landed property in Pakistan except with the previous permission of the federal government or of the provincial government. ${ }^{14}$

Further, the Home Department of the provincial government of Sindh, according to its notification dated 1 November 2009, directed that no lease, rent, nor sale of any plot of land or property shall be made in favor of foreign nationals in the province of Sindh, without seeking the prior approval of the province's Home Department. In practice however, it is observed that the above restrictions are not applied to ownership of land by companies incorporated in Pakistan, even where such companies are owned or controlled by foreign investors (footnote 5).

\section{Protection Provided under the Constitution and the Economic Reforms Act 1992}

Although the fundamental right to acquire or dispose a property, as provided in Article 23 of the Constitution, is not available to a foreigner, Article 24 of the Constitution, among other things, provides that no person shall be compulsorily deprived of his property saved in accordance with law, and no property shall be compulsorily acquired or taken possession of, saved for a public purpose and saved by the authority of law which provides for compensation. This protection provided by Article 24 is available not only to a citizen but also to a foreigner, whether a natural person or an artificial person (footnote 5).

14 Order No. 18/152/84-Poll.E (II) dated 9 September 1984 issued by the Government of Pakistan, Ministry of Interior. 
Sections 7 and 8 of the Economic Reforms Act provide statutory protection against compulsory acquisition of ownership, management, and control of any enterprise transferred by the federal government to citizens and foreigners (footnote 5).

\section{Grant of Wayleave Rights}

In Punjab and Sindh, the private partner shall be granted the right-of-way for the implementation of the project by way of government support. The PPP Act of Khyber Pakhtunkhwa prescribes that the private partner, upon the request of the contracting authority, under the terms of the law and the concession contract, shall be assisted to enjoy the right to enter upon, transit through, or do work, or fix installations on the property of third parties, as appropriate and required for the implementation of the project. In Khyber Pakhtunkhwa, any compulsory acquisition of land for a project is carried out in accordance with the Land Acquisition Act (footnote 5).

In case the private partner purchases land, a right-of-way may be granted, pursuant to Section 4 of the Easements Act, to the private partner as an owner or occupier of the said land, for the beneficial enjoyment of that land, to do and continue to do something, or to prevent and continue to prevent something being done, in or upon, or in respect of, certain other land not their own. Beneficial enjoyment includes possible convenience, remote advantage, and a mere amenity (footnote 5).

\section{Land Registry with Public Information on Land Plots}

In Pakistan, land matters are administered by the Revenue Department of each provincial government. A Revenue Department of a provincial government comprises of several officials including a Provincial Board of Revenue that overlooks any matters relating to or arising out of land, such as the maintenance of a record of rights for each province (footnote 5).

In case of transfer of property through sale, pursuant to the TPA, to confirm the right and title of the transferor in the property, the transferee or its counsel must review the transferor ownership documents and verify title to property. The transferee or its counsel should also visit the respective land department to verify the information, records, and transferor ownership documents in respect of the property. Therefore, by reviewing the transferor's ownership documents, information on the subject land shall be made available to the transferee or its counsel (footnote 5).

\section{Government Support for Public-Private Partnership Projects}

\section{Parameter}

Project funding support

Is there a dedicated government financial support mechanism for PPP projects?

What are the instruments of government financial support available under this government financial support mechanism?

\begin{tabular}{|l|c|}
\hline - Capital grant & $\checkmark$ \\
\hline - Operations grant & $\checkmark$ \\
\hline - Annuity/availability payments & $\checkmark$ \\
\hline
\end{tabular}


continued from previous page

\section{Parameter}

- Guarantees to cover

- Currency inconvertibility and transfer risk

- Foreign exchange risk

- War and civil disturbance risk

- Breach of contract risk

- Regulatory risk

- Expropriation risk

- Government payment obligation risk

- Credit risk

- Minimum demand/revenue risk

- Risk of making annuity/availability payments in a timely manner

What are the caps/ceilings for the government financial support under each of the abovementioned government financial support instruments? a

Is there a minimum PPP project size (investment) for a PPP project to be eligible for receiving government financial support?

Are there minimum financial commitment requirements for the private developer equity before the government support could be drawn?

Is the government financial support required, usually the bid parameter for PPP projects?

Are unsolicited PPP proposals eligible to receive government financial support?

Are there standard operating procedures for providing government financial support to PPP projects?

- Appraisal and approval process

- Budgeting process

- Disbursement process

- Monitoring process

- Accounting, auditing, and reporting process

Who are the signatories to the Government Financial Support Agreement?

Who is responsible for monitoring the performance of PPP projects availing government financial support?

- Independent engineer?

- Government agency?

- Ministry of Finance?

What are the other forms of government support available for PPP projects?

- Land acquisition funding support? $\quad \checkmark$

- Funding support for resettlement and rehabilitation of affected parties?

- Tax holidays/exemptions?

- Real estate development rights?

- Advertising and marketing rights?

- Interest rate/cost of debt subventions?

- Other subsidies and subventions?

Can the other forms of government support be availed over and above the government financial support through various instruments listed above?

$\checkmark=$ Yes, $x=$ No, P3A = Public Private Partnership Authority, PPP = public-private partnership, UA = unavailable.

a There are currently no caps on the guarantees. However, it is likely that details may be provided as part of secondary legislation.

Sources: Asian Development Bank. 2019. Public-Private Partnership Monitor. Second Edition. Manila. https://www.adb.org/sites/ default/files/publication/509426/ppp-monitor-second-edition.pdf; and Government of Pakistan, Public Private Partnership Authority. 2020. Public Private Partnership Authority (Amendment) Act 2021. Islamabad. http://www.senate.gov.pk/uploads/ documents/1612419098_271.pdf. 
Presently, the government has the discretion and authority to provide guarantees, on a case-by-case basis, to projects to provide comfort to the private sector. However, the PPPA Amendment Act 2021 further details the nature of support mechanisms, including the guarantees that could be extended to PPP projects as indicated below (footnote 6):

- administrative support to the private party consistent with its responsibilities under the PPP agreement and applicable laws for obtaining licenses and clearances from the government, a public sector organization or an implementing agency, for the purposes of the project on such terms and conditions as may be prescribed; provision of utility connections for power, gas, telephone and water at the project site; acquisition of land or rights of way necessary for the project; rehabilitation and resettlement of displaced persons directly required to execute the project; environmental impact assessment, safeguards, approvals, and any other local permissions and approvals;

- asset-based support to the private party, such as leasing, licensing or grant of right to mortgage and use land or infrastructure facilities owned by the government or an implementing agency;

- financial assistance through the viability gap funding (VGF);

- sovereign guarantees for political or other risks; and

- any other support prescribed in respect of a qualified project, provided that any funding or financial support given through the project development facility shall not form part of project support.

The various instruments of government support at the federal level, according to the PPPA Act 2017, modified as per PPPA Amendment Act 2021 are provided in Table 6.

\section{Table 6: Instruments of Federal Government's Financial Support in Pakistan}

\begin{tabular}{|c|c|}
\hline $\begin{array}{l}\text { Government Support/ } \\
\text { Instrument }\end{array}$ & Description \\
\hline P3A Fund (Federal) & $\begin{array}{l}\text { A non-lapsable fund through upfront grant-in-aid that shall be utilized by the PPPA in } \\
\text { connection with its functions under the PPPA Act. The management, operation and } \\
\text { maintenance of the P3A Fund shall be done by officers of the PPPA in the prescribed } \\
\text { manner. }\end{array}$ \\
\hline Viability Gap Fund & $\begin{array}{l}\text { A non-lapsable fund through upfront grant-in-aid vested in the PPPA, known as the } \\
\text { "viability gap fund," which shall be managed, controlled, and administered by the PPPA in } \\
\text { the prescribed manner. The viability gap fund shall be utilized, inter alia, to provide support } \\
\text { to those qualified projects for which a feasibility study has found them to be economically or } \\
\text { socially justified but not financially viable. }\end{array}$ \\
\hline $\begin{array}{l}\text { Project Development } \\
\text { Facility }\end{array}$ & $\begin{array}{l}\text { A non-lapsable facility through upfront grant-in-aid vested in the PPPA, known as the } \\
\text { project development facility, which shall be managed, controlled, and administered by the } \\
\text { PPPA in the prescribed manner. }\end{array}$ \\
\hline
\end{tabular}

P3A or PPPA = Public Private Partnership Authority.

Source: Government of Pakistan, Public Private Partnership Authority. 2020. Public Private Partnership Authority (Amendment) Act 2021. Islamabad. http://www.senate.gov.pk/uploads/documents/1612419098_271.pdf

Support for land acquisition and resettlement cost could be provided by the implementing agency or local government unit on a case-by-case basis. Such support would include provision of utility connections for power, gas, and water at project site; clearance of right-of-way or acquisition of land necessary for the project; and rehabilitation and resettlement necessitated due to project execution (footnote 5). 


\begin{tabular}{|c|c|}
\hline \multicolumn{2}{|l|}{ Parameter } \\
\hline Project Development Funding & \\
\hline \multicolumn{2}{|l|}{ What are the various sources of funds for public-private partnership (PPP) project preparation? } \\
\hline - Budgetary allocations & $\checkmark$ \\
\hline - Dedicated project preparation/project development fund & $\checkmark$ \\
\hline - Technical assistance from multilateral, bilateral, and donor agencies? & $\checkmark$ \\
\hline - Recovery of project preparation funding from the preferred bidder? & $\checkmark$ \\
\hline \multicolumn{2}{|l|}{$\begin{array}{l}\text { At what stage of the PPP project can the project preparation/development funding be availed by the } \\
\text { government agency? }\end{array}$} \\
\hline - Pre-feasibility stage & UA \\
\hline - Detailed feasibility stage & $\checkmark$ \\
\hline - Transaction stage & $\checkmark$ \\
\hline Is there a threshold size (investment) for a PPP project to avail project development funding? & UA \\
\hline $\begin{array}{l}\text { Is there a list of project preparation/project development activities toward which the project development } \\
\text { funding can be utilized? }\end{array}$ & UA \\
\hline Can the project development funding be utilized to appoint transaction advisors for PPP projects? & $\checkmark$ \\
\hline Is there a specific process to be followed by government agencies to appoint transaction advisors? & $\checkmark$ \\
\hline \multicolumn{2}{|l|}{ What are the payment mechanisms for making payments to transaction advisors? } \\
\hline - Time-sheet based & $\checkmark$ \\
\hline - Milestone based & $\checkmark$ \\
\hline Are there standard agreements and documents to avail project development funding? & UA \\
\hline Who are the signatories to the project development funding agreements? & UA \\
\hline
\end{tabular}

$\checkmark=$ Yes, UA = Unavailable.

The PPPA Amendment Act 2021 specifies that the Project Development Facility (PDF) shall be mainly utilized to support the preparation of any proposals for qualified projects. These regulations describe the following sources for replenishing the PDF:

- upfront grant-in-aid from the government (with PDF being a non-lapsable facility);

- a pool of funds, including contributions from international donor agencies; and

- an amount specified by the Board of Federal P3A (the fund may be replenished from time to time in the prescribed manner).

\section{Maturity of the Public-Private Partnership Market}

\section{Parameter}

Public-private partnership (PPP) project statistics

Is there a national PPP database for the country?

Is the distribution of PPP projects across infrastructure sectors available?

Is the distribution of PPP projects across various stages of the PPP lifecycle available? 
continued from previous page

\section{Parameter}

\begin{tabular}{|l|c|}
\hline Does the country publish a national PPP project pipeline? & $\checkmark$ \\
\hline At what frequency is the national PPP project pipeline published? & UA \\
\hline Is the national PPP project pipeline based on the national infrastructure plan for the country? & $\times$ \\
\hline
\end{tabular}

$\checkmark=$ Yes, $x=$ No, NA = Not Applicable, UA = Unavailable

The website of the Federal P3A publishes the list of ongoing and pipeline projects in Pakistan. Currently, the website describes only one project in the pipeline-the Construction of Water Transmission Pipeline, implemented on a PPP basis. ${ }^{15}$

The PPP units in Punjab, Sindh, and Khyber Pakhtunkhwa provinces manage and update their PPP project pipelines. The updated PPP project pipelines for Punjab and Sindh are available online. ${ }^{16}$

The Planning Commission reviews and approves the Public Sector Development Program. The Planning Commission screens and proposes potential PPP projects from the program. This is in consultation and coordination with the PPP Authority, the line ministries, and other contracting authorities. The contracting authorities have various responsibilities in relation to planning, development, procurement, implementation, execution, and monitoring of PPP projects. They also coordinate the identification and screening of projects with their respective PPP units to determine whether that project would be suitable for development as a PPP within their respective jurisdiction (footnote 5).

\section{Parameter}

Sources of Public-Private Partnership (PPP) Financing

Who are the typical entities financing PPP projects in the country?

- Private developers

- Construction contractors

- Institutional, financial, private equity investors

- Pension funds

- Insurance companies

- Banks

- Non-banking finance companies/financial Institutions

- Donor agencies

- Government agencies and state-owned enterprises

What is the distribution of financing among these entities financing PPP projects?

Does the country have the history/track record of issuing bonds by infrastructure projects?

UA UA UA UA $\checkmark$ UA

$\checkmark$

$\checkmark$
UA UA

continued on next page

15 Government of Pakistan, PPPA. Pipeline Projects. http://pppa.gov.pk/pproj.php (accessed 22 September 2020).

16 Provincial Government of Sindh, Pakistan; Finance Department, PPP Unit. Projects in Pipeline. http://www.pppunitsindh.gov.pk/projects_new. php?pid=29\&pstatus=Pipeline (accessed 22 September 2020); and Provincial Government of Punjab, Pakistan; Planning and Development Board, PPP Cell. Pipeline Projects. https://ppp.punjab.gov.pk/pipeline_projects (accessed 22 September 2020). 
continued from previous page

\section{Parameter}

How many infrastructure projects/private developers for infrastructure projects have raised funding through $\quad$ UA bond issuances?

What is the value of funding raised through capital markets by PPPs?

Does the country have a matured derivatives market to hedge certain risks associated with PPPs?

Does the country have a national development bank?

Does the country have credit rating agencies to rate infrastructure projects?

Typically, what are the credit ratings achieved/received by infrastructure projects?

Is there a threshold credit rating for infrastructure PPPs below which institutional investors, pension funds, and insurance companies would not invest in infrastructure PPPs?

What is the typical funding model for infrastructure PPPs - corporate finance or project finance?

Are there regulatory limits/restrictions for the maximum exposure that can be taken by banks to infrastructure projects?

$\checkmark=$ Yes, UA = Unavailable.

Table 7 describes the features of key infrastructure financing sources in Pakistan.

Table 7: Key Infrastructure Financing Sources in Pakistan

\begin{tabular}{|c|c|c|c|c|c|c|}
\hline Item & $\begin{array}{l}\text { Non/Limited } \\
\text { Recourse } \\
\text { Loan }\end{array}$ & $\begin{array}{l}\text { Non/Limited } \\
\text { Recourse } \\
\text { Local } \\
\text { Currency } \\
\text { Loan }\end{array}$ & $\begin{array}{c}\text { Project } \\
\text { Financing, } \\
\text { Local Public } \\
\text { Sector Banks }\end{array}$ & $\begin{array}{l}\text { Interest Rate } \\
\text { Swaps }\end{array}$ & $\begin{array}{l}\text { Currency } \\
\text { Swaps }\end{array}$ & $\begin{array}{l}\text { Project } \\
\text { Financing } \\
\text { through } \\
\text { Project Bond } \\
\text { Issuance }\end{array}$ \\
\hline $\begin{array}{l}\text { Maximum tenor } \\
\text { (in years) }\end{array}$ & $5-7$ & $10-14$ & $5-15$ & $2-5$ & $1-5$ & \\
\hline $\begin{array}{l}\text { Upfront arrangement fee } \\
\text { (bps) }\end{array}$ & $100-150$ & $100-150$ & & & & \\
\hline Floor rate & LIBOR & $\mathrm{KIBOR}^{\mathrm{a}}$ & & & & \\
\hline Margin rate (bps) & $40-50$ & $100-350$ & & & & \\
\hline $\begin{array}{l}\text { Political risk cover } \\
\text { premium (bps) }\end{array}$ & $150-400$ & & & & & \\
\hline $\begin{array}{l}\text { Percentage of foreign debt } \\
\text { out of total debt for project } \\
\text { financing }\end{array}$ & & & $30-50$ & & & \\
\hline \multicolumn{7}{|l|}{$\begin{array}{l}\text { Percentage of project } \\
\text { bonds out of total debt for } \\
\text { project financing }\end{array}$} \\
\hline Typical debt-equity ratio & & & $80: 20$ & & & \\
\hline $\begin{array}{l}\text { Timeline to financial } \\
\text { closure (month) }\end{array}$ & & & $<12$ months & & & \\
\hline $\begin{array}{l}\text { Minimum DSCR covenant } \\
\text { levels }(x)\end{array}$ & & & $1.3 x-1.6 x$ & & & \\
\hline Nominal interest rates & & & & & & \\
\hline
\end{tabular}


Table 7 continued

\begin{tabular}{|c|c|c|c|c|c|c|}
\hline Item & $\begin{array}{l}\text { Non/Limited } \\
\text { Recourse } \\
\text { Loan }\end{array}$ & $\begin{array}{l}\text { Non/Limited } \\
\text { Recourse } \\
\text { Local } \\
\text { Currency } \\
\text { Loan }\end{array}$ & $\begin{array}{c}\text { Project } \\
\text { Financing, } \\
\text { Local Public } \\
\text { Sector Banks }\end{array}$ & $\begin{array}{c}\text { Interest Rate } \\
\text { Swaps }\end{array}$ & $\begin{array}{c}\text { Currency } \\
\text { Swaps }\end{array}$ & $\begin{array}{l}\text { Project } \\
\text { Financing } \\
\text { through } \\
\text { Project Bond } \\
\text { Issuance }\end{array}$ \\
\hline \multicolumn{7}{|l|}{ Real interest rates } \\
\hline Security package & & & & & & \\
\hline
\end{tabular}

bps = basis points, $\mathrm{DSCR}=$ debt service coverage ratio, $\mathrm{KIBOR}=$ Karachi Interbank Offered Rate, LIBOR = London Interbank Offered Rate, $x=$ times.

a As published by the State Bank of Pakistan.

Source: Asian Development Bank. 2019. Public-Private Partnership Monitor. Second Edition. Manila. https://www.adb.org/sites/default/ files/publication/509426/ppp-monitor-second-edition.pdf.

Table 8 shows the most active banks during 2018-2019 for project finance in Pakistan.

Table 8: Banks in Project Finance in Pakistan in 24 Months Preceding December 2019

\begin{tabular}{|c|c|c|c|}
\hline \multirow[b]{2}{*}{ Name } & \multicolumn{2}{|c|}{ Total Project Financing } & \multirow[b]{2}{*}{ Transaction } \\
\hline & (\$ million) & (PRs billion) & \\
\hline National Bank of Pakistan & $2,892.70$ & 447.96 & $\ldots$ \\
\hline Habib Bank & $2,754.00$ & 426.48 & 8 \\
\hline United Bank Limited & 58.14 & 99.00 & 3 \\
\hline Meezan Bank & $\ldots$ & $\ldots$ & $\ldots$ \\
\hline Bank Alfalah & $\ldots$ & $\ldots$ & $\ldots$ \\
\hline Bank of Punjab & $\ldots$ & $\ldots$ & $\ldots$ \\
\hline Askari Bank & $\ldots$ & $\ldots$ & $\ldots$ \\
\hline Faysal Bank & $\ldots$ & $\ldots$ & $\ldots$ \\
\hline
\end{tabular}

$\ldots=$ data not available, $\$=$ United States dollar, PRs = Pakistan rupees.

Sources: Asian Development Bank (ADB) Office of Public-Private Partnership; and ADB Pakistan Resident Mission.

Equity sponsors also play an important role in project development. Table 9 shows the most active project sponsors during 2018-2019.

Table 9: Active Project Sponsors in Pakistan in 24 Months Preceding December 2019

\begin{tabular}{|c|c|c|c|}
\hline \multirow[b]{2}{*}{ Name } & \multicolumn{2}{|c|}{ Total Project Financing } & \multirow[b]{2}{*}{ Transaction } \\
\hline & (\$ million) & (PRs billion) & \\
\hline Pak Matiari Lahore Transmission Line Company Pvt. Ltd. & $1,700.0$ & 263.3 & $\ldots$ \\
\hline Thar Energy Limited & 520.0 & 80.5 & $\ldots$ \\
\hline Sindh Engro Coal Mining Company (Phase 2) & 216.0 & 33.4 & $\ldots$ \\
\hline Lucky Electric Power Company Limited & 190.0 & 29.4 & $\ldots$ \\
\hline Metro Power Company & 77.7 & 12.0 & $\ldots$ \\
\hline Indus Group & 70.0 & 10.8 & $\ldots$ \\
\hline Naveena Group & 68.1 & 10.5 & $\ldots$ \\
\hline Yunus Brothers Group & 67.2 & 10.4 & $\ldots$ \\
\hline
\end{tabular}


Table 9 continued

\begin{tabular}{|l|c|c|c|}
\hline & \multicolumn{2}{c}{ Total Project Financing } \\
Name & (\$ million) & (PRs billion) & Transaction \\
\hline DIN Group & 67.1 & 10.4 & $\ldots$ \\
\hline $\begin{array}{l}\text { ACT Group (Akhtar Textile, Ismail Industries Limited and Tapal } \\
\text { Group) }\end{array}$ & 66.4 & 10.3 & $\ldots$ \\
\hline
\end{tabular}

$\ldots=$ data not available, $\$=$ United States dollar, PRs = Pakistan rupees.

Sources: Asian Development Bank (ADB) Office of Public-Private Partnership; and ADB Pakistan Resident Mission.

\section{Credit Rating Agencies in Pakistan}

In Pakistan, there are only two credit rating agencies:

- The Pakistan Credit Rating Agency Limited (PACRA), established in 1994, is the first credit rating agency with a joint venture agreement between the International Finance Corporation (IFC), Fitch Ratings, and Lahore Stock Exchange. Since 2002, after the divestment of the IFC and Fitch Ratings, the entity has been running with local ownership. PACRA offers various products: ${ }^{17}$

- Entity Ratings,

- Instrument Ratings,

- Structured Finance Rating,

- Insurer Financial Strength Rating,

- Project Grading,

- Fund Stability Rating,

- Star Ranking/Fund Performance Ranking,

- Capital Protection Rating,

- Asset Manager Rating, and

- Security Agency Grading.

- The VIS Credit Rating Company Limited (formerly JCR-VIS Credit Rating Company) is a full-service rating agency. It provides independent rating services in Pakistan. The agency's shareholders include Vital Information Services (Pvt.) Limited (VIS) (Pakistan's only independent financial research organization), Pakistan Stock Exchange Limited, and ISE Towers RIET Management Company Limited. The firm primarily provides the following products: ${ }^{18}$

- Entity Ratings,

- Instrument Ratings,

- Management Quality Ratings,

- Fund Rankings,

- Insurer Financial Strength Ratings,

- Corporate Governance Ratings, and

- Fund Ratings. 


\section{Sector-Specific Public-Private Partnership Landscape}

\section{A. ROADS}

Length and quality of road infrastructure projects in Pakistan are presented in Table 10.

Table 10: Status of Road Infrastructure Projects

\begin{tabular}{|l|r|c|}
\hline Item & Value & Unit \\
\hline Length of the total road network & 263,775 & kilometer \\
\hline Quality of road infrastructure & 4.0 & 1 (low) - 7 (high) \\
\hline
\end{tabular}

Sources: Government of Pakistan, Finance Division. 2020. Pakistan Economic Survey 2019-2020. Islamabad. https://pc.gov.pk/uploads/ cpec/PES_2019_20.pdf; Trading Economics. Pakistan-Road Total Network; and The Global Economy. Compare Countries. https://www.theglobaleconomy.com/compare-countries/ (accessed 10 September 2020).

\section{Contracting Agencies in the Road Sector}

The National Highway Authority (NHA) is responsible for managing the design, development, and operation of a 12,000-kilometer ( $\mathrm{km}$ ) network of national highways and motorways. The NHA is empowered, under NHA Act, to initiate, operate, and award projects through private sector financing. Depending on the nature of the project, the NHA could be assisted by the central Public-Private Partnership (PPP) Unit of Pakistan, or the local PPP cells. Although these entities are not the contracting agencies, they still play a role in the procurement process (footnote 5 ).

\section{Road Sector Laws and Regulations}

According to the Private Participation in National Highways Policy, concessionaires will be given the right to collect tolls at locations they consider appropriate and are approved by the NHA, within their specified concession area. The NHA procured five projects under PPP modality-i.e., build-operate-transfer (BOT) before operationalization of the Federal Public Private Partnership Authority (P3A). The new projects are being taken up in accordance with the PPPA Act.

The PPP Unit of the NHA (or the PPP Cell) was established comprising of highly professional and committed staff. It is responsible for developing and processing all PPP projects. In 2009, the NHA issued the standard operating procedures (SOPs), which serve as the policy and regulatory framework for private sector participation in the road sector (called the PPP Policy and Regulatory Framework).

As per the SOPs, the NHA shall prepare and regularly update the PPP Highway Programme comprising national highway, motorway, tunnel, and bridge projects that may be suitable for private sector participation. The NHA shall carry out all PPP projects, whether solicited or unsolicited (unsolicited projects are considered only in exceptional cases), using standard bidding procedures. The SOPs indicate that the PPP program shall be 
developed within the national transport policy and sector program for Pakistan wherein pre-feasibility studies will determine the characteristics and viability of each PPP project.

The SOPs further elaborate on principles of tolling (Toll Policy), operation and maintenance (Operational and Road Management Policy), financial and contractual arrangements, incentives, security package, and PPP tendering process and requirements.

\subsection{Foreign Investment Restrictions in the Road Sector}

The maximum equity investment allowed for foreign investors in greenfield projects is $100 \%$ (Table 11).

Table 11: Foreign Investment in the Road Sector

\begin{tabular}{|l|c|c|c|c|}
\hline Item & 2017 & 2018 & 2019 \\
\hline Maximum allowed foreign ownership of equity in greenfield projects & $100 \%$ & $100 \%$ & $100 \%$ \\
\hline
\end{tabular}

Source: Asian Development Bank. 2019. Public-Private Partnership Monitor. Second Edition. Manila. https://www.adb.org/sites/default/ files/publication/509426/ppp-monitor-second-edition.pdf.

\subsection{Standard Contracts in the Road Sector}

\begin{tabular}{l|c} 
Type of Contract & Availability \\
\hline Public-private partnership/concession agreement & $\checkmark$ \\
\hline Performance-based operation and maintenance contract & $\checkmark$ \\
\hline Engineering, procurement, and construction contract & $\checkmark$ \\
\hline$\checkmark=$ Yes \\
$\begin{array}{l}\text { Source: Asian Development Bank. 2019. Public-Private Partnership Monitor. Second Edition. Manila. https://www.adb.org/sites/default/ } \\
\text { files/publication/509426/ppp-monitor-second-edition.pdf. }\end{array}$
\end{tabular}

\section{Road Sector Master Plan}

As per the PPP Policy and Regulatory Framework issued by the NHA, the NHA shall prepare and update on a regular basis a list of projects on national highways, motorways, tunnels, and bridges. The PPP Cell of the NHA shall conduct pre-feasibility studies following the issued guidelines and prepare a pipeline of projects for private sector participation.

The website of the NHA provides a list of PPP projects. The latest information available on this website includes project updates up to October 2018. In addition, the NHA also published the PPP project plan for 2019-2020. Table 12 shows the list of road sector projects in Pakistan.

Table 12: Road Sector Projects in Pakistan at Various Stages

\begin{tabular}{|c|c|c|c|c|c|}
\hline \multirow[b]{2}{*}{ Project } & \multirow{2}{*}{$\begin{array}{l}\text { Length } \\
(\mathrm{km})\end{array}$} & \multicolumn{2}{|c|}{ Project Cost } & \multirow[b]{2}{*}{ Project Scope } & \multirow[b]{2}{*}{ Status } \\
\hline & & (\$ million) & (PRs million) & & \\
\hline $\begin{array}{l}\text { Hyderabad-Sukkur Motorway } \\
(M-6)\end{array}$ & 300 & $1,117.21$ & $1,73,000$ & $\begin{array}{l}\text { Construction of new } \\
\text { six-lane motorway }\end{array}$ & $\begin{array}{l}\text { Design completed, } \\
\text { feasibility in hand, } \\
\text { procurement to be } \\
\text { initiated. Proposed } \\
\text { on PPP as per PSDP } \\
2019-2020 \text {. }\end{array}$ \\
\hline
\end{tabular}


Table 12 continued

\begin{tabular}{|c|c|c|c|c|c|}
\hline \multirow[b]{2}{*}{ Project } & \multirow{2}{*}{$\begin{array}{l}\text { Length } \\
\text { (km) }\end{array}$} & \multicolumn{2}{|c|}{ Project Cost } & \multirow[b]{2}{*}{ Project Scope } & \multirow[b]{2}{*}{ Status } \\
\hline & & (\$ million) & (PRs million) & & \\
\hline Sialkot-Kharian Motoway & 70 & 258.32 & 40,000 & $\begin{array}{l}\text { Construction of new } \\
\text { six-lane motorway }\end{array}$ & $\begin{array}{l}\text { Design and } \\
\text { feasibility stage. } \\
\text { Proposed on PPP as } \\
\text { per PSDP 2019- } \\
2020 .\end{array}$ \\
\hline Kharian-Rawalpindi Motorway & 115 & 484.34 & 75,000 & $\begin{array}{l}\text { Construction of new } \\
\text { six-lane, divided } \\
\text { motorway }\end{array}$ & $\begin{array}{l}\text { Procurement } \\
\text { of consultant } \\
\text { for design and } \\
\text { feasibility initiated. } \\
\text { Proposed on PPP as } \\
\text { per PSDP 2019- } \\
2020 \text {. }\end{array}$ \\
\hline $\begin{array}{l}\text { Karachi Northern Bypass } \\
(M-10)\end{array}$ & 50 & 64.58 & 10,000 & $\begin{array}{l}\text { Conversion of } \\
\text { existing two-lane } \\
\text { into four-lane } \\
\text { divided facility }\end{array}$ & $\begin{array}{l}\text { Preparation stage. } \\
\text { Proposed on PPP as } \\
\text { per PSDP 2019- } \\
2020 .\end{array}$ \\
\hline $\begin{array}{l}\text { Nowshera-Peshawar Highway } \\
(\mathrm{N}-5)\end{array}$ & 43 & 71.04 & 11,000 & $\begin{array}{l}\text { Conversion of } \\
\text { existing four- } \\
\text { lane into six-lane } \\
\text { expressway on BOT } \\
\text { basis }\end{array}$ & Preparation stage \\
\hline $\begin{array}{l}\text { Pindi Bhattian Faisalabad- } \\
\text { Multan Motorway }(\mathrm{M}-4)\end{array}$ & 294 & 516.63 & 80,000 & $\begin{array}{l}\text { Conversion of } \\
\text { existing four-lane } \\
\text { into a six-lane } \\
\text { motorway plus } \\
\text { overlay on existing } \\
\text { four lanes }\end{array}$ & Preparation stage \\
\hline $\begin{array}{l}\text { Operation Concessions of } \\
\mathrm{N}-5\end{array}$ & & & & $\begin{array}{l}\text { Operating } \\
\text { concession of } \\
\text { identified stretch of } \\
\text { national highways } \\
\text { and motorways }\end{array}$ & Preparation stage \\
\hline Southern Bypass Peshawar & $\begin{array}{l}\text { To be } \\
\text { defined }\end{array}$ & 64.58 & 10,000 & $\begin{array}{l}\text { Construction of new } \\
\text { road }\end{array}$ & Preparation stage \\
\hline Southern Bypass Hyderabad & $\begin{array}{l}\text { To be } \\
\text { defined }\end{array}$ & 77.49 & 12,000 & $\begin{array}{l}\text { Construction of new } \\
\text { road }\end{array}$ & Preparation stage \\
\hline $\begin{array}{l}\text { Dualization and Rehabilitation } \\
\text { of Karachi-Quetta-Chamman } \\
\text { Road } \\
(\mathrm{N}-25)\end{array}$ & 790 & 129.00 & 20,000 & $\begin{array}{l}\text { Conversion of } \\
\text { existing two-lane } \\
\text { into four-lane dual } \\
\text { carriageway }\end{array}$ & $\begin{array}{l}\text { Proposed on PPP as } \\
\text { per PSDP 2019- } \\
2020 .\end{array}$ \\
\hline $\begin{array}{l}\text { Chakdara-Bagh Dheri } \\
\text { extension of SWAT expressway }\end{array}$ & 71 & $\ldots$ & $\ldots$ & $\begin{array}{l}\text { Construction of new } \\
\text { four-lane motorway }\end{array}$ & $\begin{array}{l}\text { Proposed on PPP as } \\
\text { per PSDP 2019- } \\
2020 .\end{array}$ \\
\hline $\begin{array}{l}\text { Construction of Shahdara } \\
\text { flyover bridge }\end{array}$ & $\begin{array}{l}\text { To be } \\
\text { defined }\end{array}$ & 32.28 & 5,000 & $\begin{array}{l}\text { Construction of } \\
\text { four-lane flyover } \\
\text { bridge }\end{array}$ & $\begin{array}{l}\text { Preparation stage. } \\
\text { Proposed on PPP as } \\
\text { per PSDP 2019- } \\
2020 .\end{array}$ \\
\hline
\end{tabular}


Table 12 continued

\begin{tabular}{|c|c|c|c|c|c|}
\hline \multirow[b]{2}{*}{ Project } & \multirow{2}{*}{$\begin{array}{l}\text { Length } \\
\text { (km) }\end{array}$} & \multicolumn{2}{|c|}{ Project Cost } & \multirow[b]{2}{*}{ Project Scope } & \multirow[b]{2}{*}{ Status } \\
\hline & & (\$ million) & (PRs million) & & \\
\hline $\begin{array}{l}\text { Construction of additional } \\
\text { carriageway from Balkasar } \\
(M-2) \text { to Mianwali }\end{array}$ & 130 & 206.64 & 32,000 & $\begin{array}{l}\text { Conversion of } \\
\text { existing two-lane } \\
\text { into four-lane dual } \\
\text { carriageway }\end{array}$ & $\begin{array}{l}\text { Preparation stage. } \\
\text { Proposed on PPP as } \\
\text { per PSDP 2019- } \\
2020 .\end{array}$ \\
\hline $\begin{array}{l}\text { Dualization of Mianwali- } \\
\text { Muzafargarh Section }\end{array}$ & 290 & 464.93 & 72,000 & $\begin{array}{l}\text { Conversion of } \\
\text { existing two-lane } \\
\text { into four-lane dual } \\
\text { carriageway }\end{array}$ & $\begin{array}{l}\text { Preparation stage. } \\
\text { Proposed on PPP as } \\
\text { per PSDP 2019- } \\
2020 .\end{array}$ \\
\hline $\begin{array}{l}\text { Nullah Lai Transportation } \\
\text { Corridor }\end{array}$ & 23 & ... & $\ldots$ & $\begin{array}{l}\text { Construction of new } \\
\text { urban expressway }\end{array}$ & $\begin{array}{l}\text { Rawalpindi } \\
\text { Development } \\
\text { Authority is the } \\
\text { procuring authority } \\
\text { for this project. }\end{array}$ \\
\hline
\end{tabular}

$\ldots=$ data not available, $\$=$ United States dollar, $\mathrm{BOT}=$ build-own-operate, $\mathrm{km}=$ kilometer, $\mathrm{PPP}=$ public-private partnership, PRs = Pakistan rupees, PSDP = Public Sector Development Program

Sources: Asian Development Bank; Government of Pakistan, National Highway Authority (NHA). List of Upcoming PPP Projects as per PSDP 2019-20. https://nha.gov.pk/wp-content/uploads/2016/04/List-of-Upcoming-PPP-Projects-as-Per-PSDP-2019-20.pdf (accessed 24 September 2020); and Government of Pakistan, NHA. List of PPP Projects under Implementation. https://nha.gov.pk/ wp-content/uploads/2016/04/List-of-PPP-Project-as-of-10-10-2018.pdf (accessed 24 September 2020).

\section{Projects under Preparation and Procurement in the Road Sector}

The list of projects under preparation and planning are presented in Table 12 and reflected in Figure 10.

\section{Figure 10: Public-Private Partnership Road Projects under Preparation and Procurement}

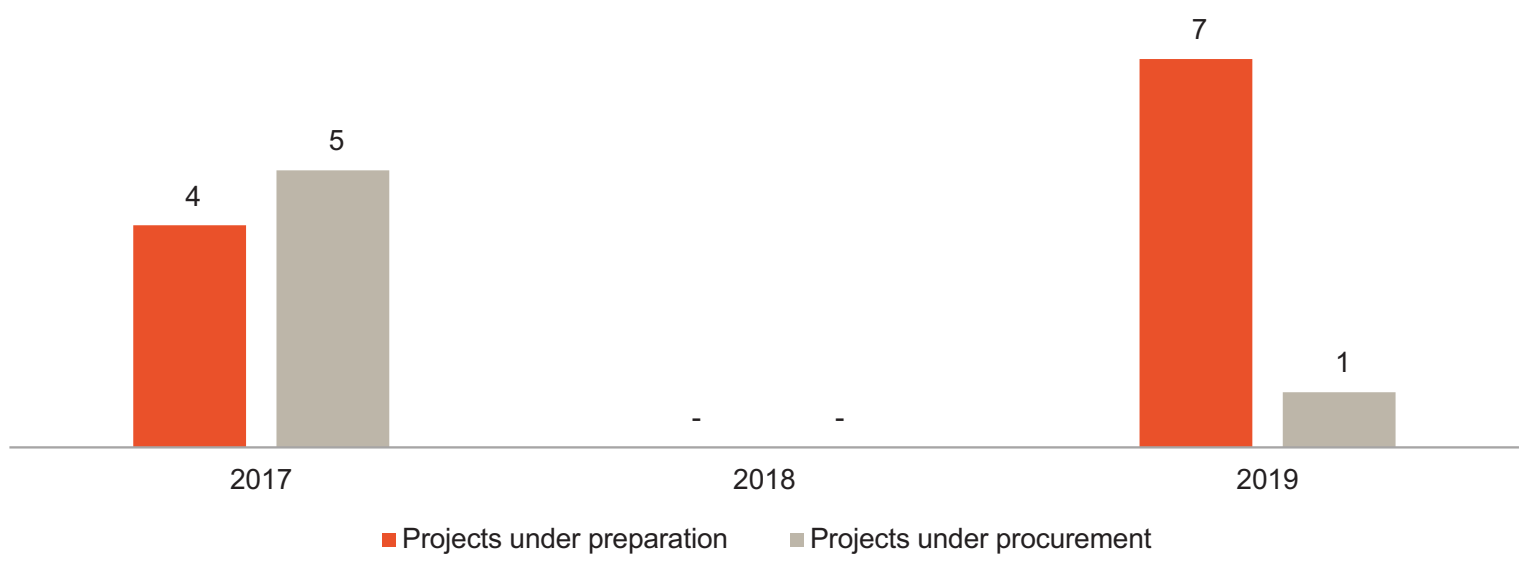

Note: The hyphen symbol (-) means there are no projects in the sector, or data are unavailable, or not applicable.

Source: Asian Development Bank. 2019. Public-Private Partnership Monitor. Second Edition. Manila. https://www.adb.org/sites/ default/files/publication/509426/ppp-monitor-second-edition.pdf; and Government of Pakistan, National Highway Authority. 


\section{Features of Past Public-Private Partnership Projects in the Road Sector}

It may be noted that the World Bank Private Participation in Infrastructure (PPI) database does not indicate any projects in the road sector that achieved financial closure in Pakistan.

However, as per the NHA website, the projects are under various stages of implementation, as shown in Table 13.

Table 13: Public-Private Partnership Pipeline Projects in the Road Sector

\begin{tabular}{|c|c|c|c|c|c|}
\hline \multirow[b]{2}{*}{ Project } & \multirow{2}{*}{$\begin{array}{l}\text { Length } \\
\text { (km) }\end{array}$} & \multicolumn{2}{|c|}{ Project Cost } & \multirow[b]{2}{*}{ Project Scope } & \multirow[b]{2}{*}{ Status } \\
\hline & & (\$ million) & (PRs million) & & \\
\hline $\begin{array}{l}\text { Lahore-Islamabad Motorway } \\
(M-2)\end{array}$ & 357 & 297.11 & 46,007 & $\begin{array}{l}\text { Overlay and } \\
\text { modernization }\end{array}$ & $\begin{array}{l}\text { Operational since } \\
\text { August } 2016\end{array}$ \\
\hline $\begin{array}{l}\text { Karachi-Hyderabad Motorway } \\
(\text { M-9) }\end{array}$ & 136 & 285.77 & 44,251 & $\begin{array}{l}\text { Conversion of } \\
\text { existing four-lane } \\
\text { highway into six- } \\
\text { lane motorway }\end{array}$ & $\begin{array}{l}\text { Substantially } \\
\text { complete ( } 94 \%) \text {; } \\
\text { operational since } \\
\text { June } 2018\end{array}$ \\
\hline $\begin{array}{l}\text { Habibabad Bridge } \\
(\mathrm{N}-5)\end{array}$ & 2 & 5.37 & 831 & $\begin{array}{l}\text { Construction of new } \\
\text { four-lane railway } \\
\text { overhead bridge on } \\
\mathrm{N}-5\end{array}$ & $\begin{array}{l}\text { Operational since } \\
\text { April } 2015\end{array}$ \\
\hline $\begin{array}{l}\text { Karachi Thatta Dual } \\
\text { Carriageway Project }\end{array}$ & 49 & 56.83 & 8,800 & $\begin{array}{l}\text { Enhancement of the } \\
\text { road quality of the } \\
N-5 \text { highway }\end{array}$ & $\begin{array}{l}\text { The financing } \\
\text { documents } \\
\text { were signed on } \\
29 \text { December } \\
2016 \text { and the } \\
\text { construction works } \\
\text { for the project is } \\
\text { complete. }\end{array}$ \\
\hline $\begin{array}{l}\text { Hyderabad Mirpurkhas Dual } \\
\text { Carriageway }\end{array}$ & 58 & 43.91 & 6,800 & $\begin{array}{l}\text { The 60-km dual } \\
\text { carriageway is } \\
\text { connecting the } \\
\text { two major cities } \\
\text { of the province, } \\
\text { Hyderabad and } \\
\text { Mirpurkhas, which } \\
\text { aims to facilitate } \\
\text { growth and } \\
\text { efficiency for the } \\
\text { province. }\end{array}$ & $\begin{array}{l}\text { The construction } \\
\text { of the project was } \\
\text { completed by } \\
\text { September } 2012 \text {. }\end{array}$ \\
\hline Lahore Ring Road Loop 1 and 2 & $\ldots$ & $\ldots$ & $\ldots$ & $\ldots$ & $\ldots$ \\
\hline
\end{tabular}

$\ldots=$ data not available, $\$$ = United States dollar, $\mathrm{km}=$ kilometer, $\mathrm{PRs}=$ Pakistan rupees.

Source: Government of Pakistan, Public-Private Partnership Unit; and Provincial Government of Sindh, Finance Department. Pakistan.

For the purpose of consistency and reliability, data from the World Bank PPI database are reflected in Figures 11-15. 
Figure 11 presents the number of PPP projects procured through various modes including direct appointment, unsolicited bids, and competitive bids in Pakistan's road sector.

Figure 11: Modes of Procurement for Public-Private Partnership Road Projects

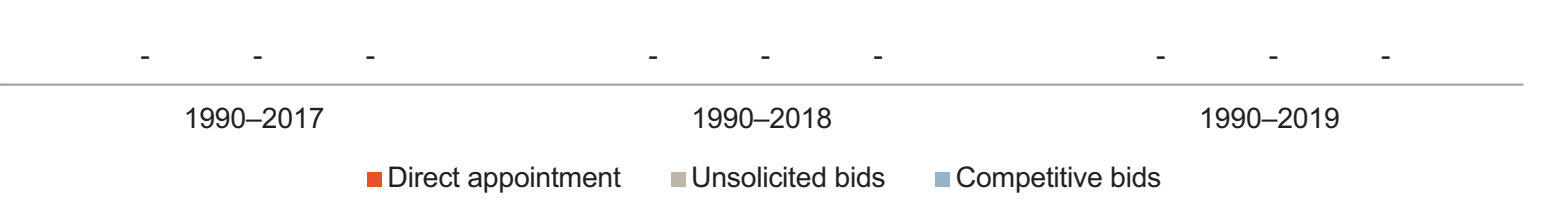

Note: Only active and concluded projects are considered in the above graph. The hyphen symbol (-) means there are no projects in the sector, or data are unavailable, or not applicable according to the database.

Source: World Bank. Infrastructure Finance, PPPs and Guarantees. Country Snapshots. Pakistan. https://ppi.worldbank.org/en/ snapshots/country/pakistan (accessed 1 September 2020).

Figure 12 shows the number of PPP projects that have reached financial closure, and the total value of those projects in Pakistan's road sector.

\section{Figure 12: Public-Private Partnership Road Projects Reaching Financial Closure}

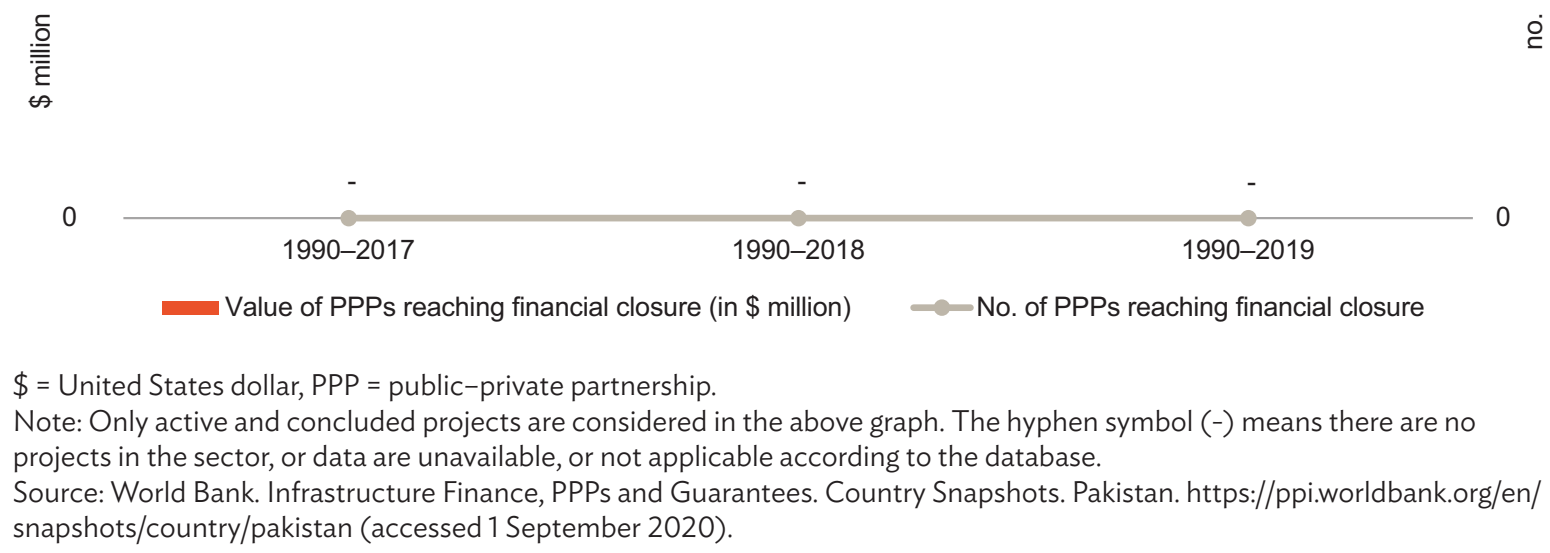


Figure 13 presents the number of PPP projects that have received foreign sponsor participation in Pakistan's road sector.

\section{Figure 13: Public-Private Partnership Road Projects with Foreign Sponsor Participation}

0

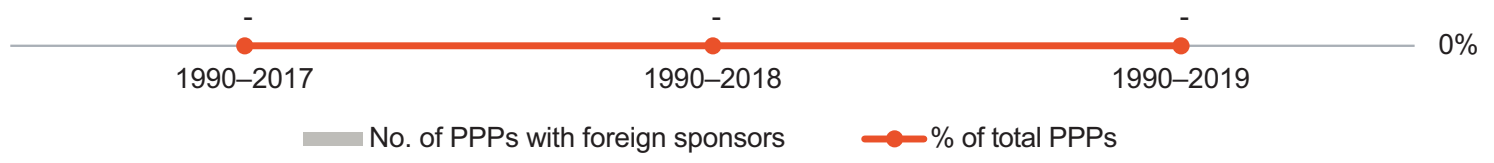

PPP = public-private partnership.

Note: Only active and concluded projects are considered in the above graph. The hyphen symbol (-) means there are no projects in the sector, or data are unavailable, or not applicable according to the database.

Source: World Bank. Infrastructure Finance, PPPs and Guarantees. Country Snapshots. Pakistan. https://ppi.worldbank.org/en/ snapshots/country/pakistan (accessed 1 September 2020).

Figure 14 shows the number of PPP projects that have received government support, including the viability gap funding (VGF) mechanism, government guarantees, and availability or performance payment in Pakistan's road sector.

\section{Figure 14: Government Support to Public-Private Partnership Road Projects}

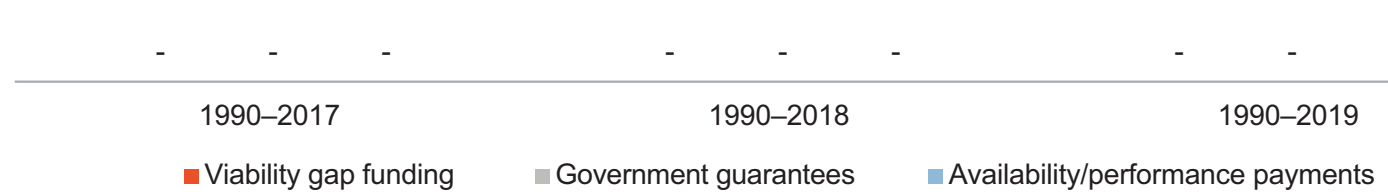

Note: Only active and concluded projects are considered in the above graph. The hyphen symbol (-) means there are no projects in the sector, or data are unavailable, or not applicable according to the database.

Source: World Bank. Infrastructure Finance, PPPs and Guarantees. Country Snapshots. Pakistan. https://ppi.worldbank.org/en/ snapshots/country/pakistan (accessed 1 September 2020). 
Figure 15 presents the number of PPP projects that have received payment in the form of user charges and government pay (off-take) in Pakistan's road sector.

Figure 15: Payment Mechanisms for Public-Private Partnership Road Projects

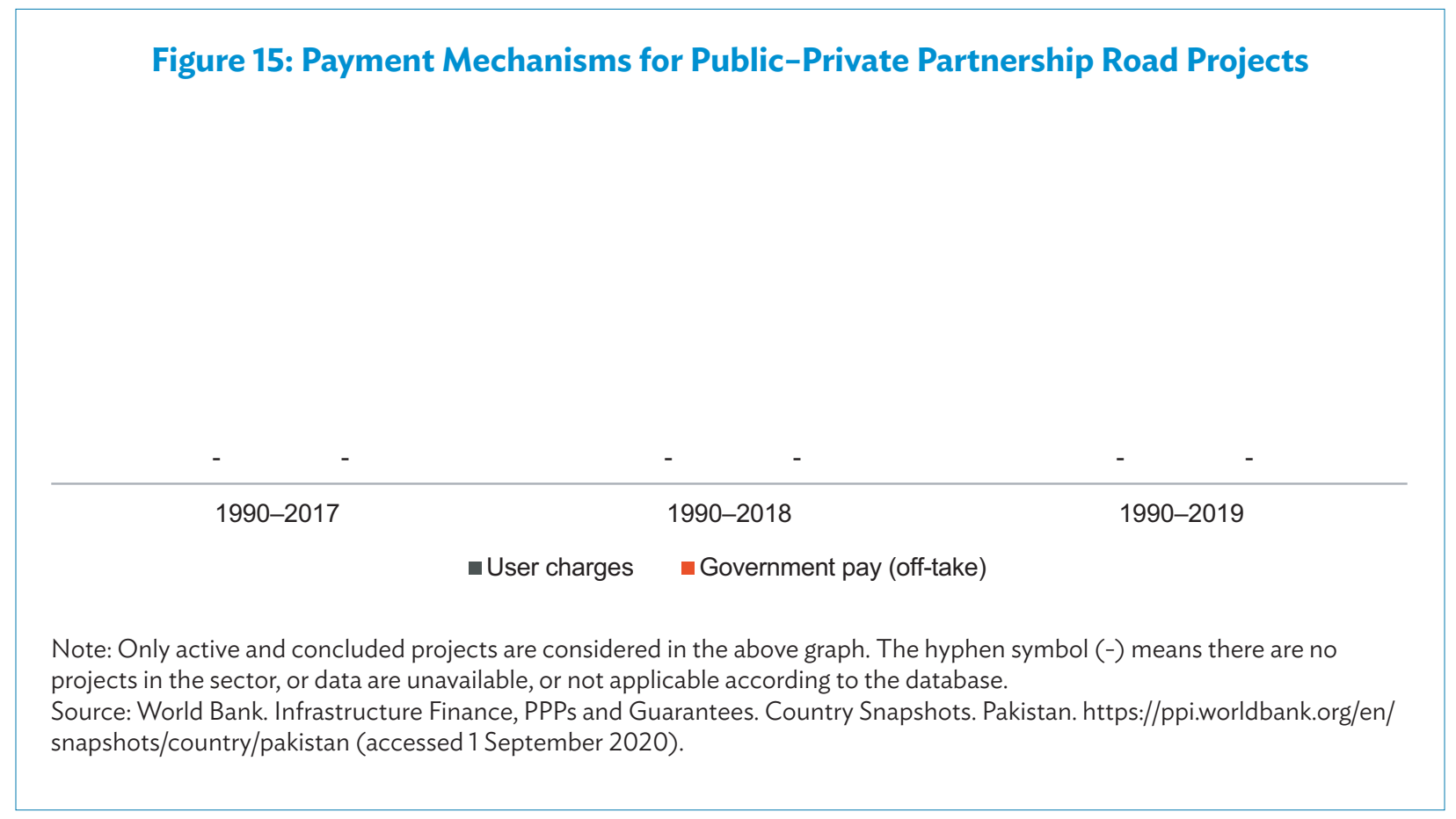

\subsection{Tariffs for Public-Private Partnership Road Projects}

The NHA has issued standard operating procedures (SOPs) for national highway tolling (NHA Tolling Policy 2010) and SOPs for public-private partnership projects. Both of these documents define the tariff or tolling principles for national highways and the escalation principles. The SOPs for PPP projects indicate that, "Consistent with the Concession Agreement, Concessionaires will be given the right to collect tolls at locations they consider appropriate and are approved by the NHA, within their specified Concession Area, using either an 'open' or 'closed' toll system as contained in the bidding documents. The tolling arrangements at the interface between two Concession Areas shall be agreed between the Concessionaires concerned and the NHA in consultation with any other provincial and/or local governments, if involved." The toll levels for the PPP projects are generally fixed based on the viability of the project. For financially viable projects, the tolls proposed by private developers will be evaluated, while for projects requiring government support, the tolls are determined by the NHA. ${ }^{19}$

19 Government of Pakistan, Ministry of Communications, National Highway Authority, Road Asset Management System Section. 2010. NHA Tolling Policy. Islamabad. http://nha.gov.pk/wp-content/uploads/2016/04/SOP-for-NHA-Tolling-Policy.docx. 
Table 14 shows the toll rates for one of the non-PPP projects that is operational.

Table 14: Tariffs for Toll Roads

\begin{tabular}{|c|c|c|c|}
\hline \multirow[b]{2}{*}{ Category } & \multicolumn{3}{|c|}{$\begin{array}{c}\text { Toll Rates as of } 1 \text { July } 2018 \\
\text { (PRs) }\end{array}$} \\
\hline & National Highways & Kohat Tunnel (N-55) & IMDCW (N-75) \\
\hline Car & 30 & 70 & 60 \\
\hline Wagon & 50 & 240 & 80 \\
\hline Buses & 100 & 290 & 170 \\
\hline 2-Axle trucks & 120 & 290 & 200 \\
\hline 3-Axle trucks & 120 & 290 & 200 \\
\hline Articulated trucks & 250 & 440 & 400 \\
\hline
\end{tabular}

IMDCW = Islamabad-Muzaffarabad Dual Carriageway, $\mathrm{PRs}=$ Pakistan rupees.

Source: Government of Pakistan, National Highway Authority. https://nha.gov.pk/ettmmap/highways-2/ (accessed 1 September 2020).

\subsection{Typical Risk Allocation for Public-Private Partnership Projects in the Road Sector}

A typical risk allocation for a toll project based on the SOPs for PPP projects is indicated in Table 15.

Table 15: Risk Allocation of Public-Private Partnership Projects in the Road Sector

\begin{tabular}{|c|c|c|c|c|}
\hline Risk Type & Private & Public & Shared & Comment \\
\hline Traffic risk & $\checkmark$ & & & \\
\hline Collection risk & $\checkmark$ & & & \\
\hline Tariff risk & $\checkmark$ & & & \\
\hline Competition risk & & & & Not available \\
\hline Government payment risk & $\checkmark$ & & & \\
\hline Environmental and social risk & & $\checkmark$ & & \\
\hline Land acquisition risk & & $\checkmark$ & & \\
\hline Permits & & $\checkmark$ & & \\
\hline Geotechnical risk & & & & $\begin{array}{l}\text { The risk depends on the nature of project and } \\
\text { geography. In case of tunnels, risk is very high } \\
\text { and needs to be addressed accordingly. In } \\
\text { normal road projects, the risk is not very high } \\
\text { and rests with the private sector. }\end{array}$ \\
\hline $\begin{array}{l}\text { Brownfield risk: inventories, studies, } \\
\text { property boundaries, project scope }\end{array}$ & & $\checkmark$ & & \\
\hline Political risk & & $\checkmark$ & & \\
\hline Force majeure & & & & Not available \\
\hline Foreign exchange risk & $\checkmark$ & & & \\
\hline
\end{tabular}

Source: Asian Development Bank. 2019. Public-Private Partnership Monitor. Second Edition. Manila. https://www.adb.org/sites/default/ files/publication/509426/ppp-monitor-second-edition.pdf. 


\subsection{Financing Details of Public-Private Partnership Projects in the Road Sector}

Table 16 presents the financing details of PPP road sector projects in Pakistan.

Table 16: Financing of Public-Private Partnership Projects in the Road Sector

\begin{tabular}{|c|c|c|c|}
\hline Item & 1990-2017 & $1990-2018$ & 1990-2019 \\
\hline PPP projects with foreign lending participation & $x$ & $x$ & $x$ \\
\hline $\begin{array}{l}\text { PPP projects that received export credit agency/international financing } \\
\text { institution support }\end{array}$ & $x$ & $x$ & $x$ \\
\hline Typical debt-equity ratio & \multicolumn{3}{|c|}{$30: 70$} \\
\hline Time for financial closure & \multicolumn{3}{|c|}{6 months } \\
\hline Typical concession period & \multicolumn{3}{|c|}{25 years } \\
\hline Typical financial internal rate of return & \multicolumn{3}{|c|}{$15 \%-18 \%$} \\
\hline
\end{tabular}

$x=$ No, PPP $=$ public - private partnership.

Source: World Bank. Infrastructure Finance, PPPs and Guarantees. Country Snapshots. Pakistan. https://ppi.worldbank.org/en/ snapshots/country/pakistan (accessed 1 September 2020).

\section{Challenges in the Road Sector}

Below are the challenges observed in the road sector (footnote 5):

- Inconsistencies between policy and institutional development. These include the lack of comprehensive strategy and action plan, inadequate institutional capacity, and poor coordination between agencies on road safety.

- Operation and maintenance issues. Transport O\&M is inefficient.

- Road safety issues. Road safety is a serious issue in Pakistan due to poor safety design, poor vehicle regulation, and inadequate traffic enforcement and driver training. There is, therefore, a need to adopt a national road safety strategy with clear action plan and targets.

- Lack of capacity among federal and provincial agencies. Suboptimal contract management and governance-related challenges have led to delays in construction and cost increases.

\section{B. RAILWAYS}

Table 17 presents the length, carrying capacity, and quality of railway projects in Pakistan.

Table 17: Status of Railway Projects

\begin{tabular}{|l|r|c|}
\hline Item & Value & Unit \\
\hline Length of total railway network & 9,255 & total route (km) \\
\hline Total no. of passengers carried & 24,903 & million passenger-km \\
\hline Total volume of freight carried & 5,031 & million ton-km \\
\hline Quality of railway infrastructure & 3.8 & 1 (low) - 7 (high) \\
\hline
\end{tabular}

$\mathrm{km}=$ kilometer.

Sources: The Economist Intelligence Unit. Infrascope 2018: Pakistan Country Profile. https://infrascope.eiu.com (accessed 1 September 2020); The Global Economy. Railway Passengers_Country Rankings. https://www.theglobaleconomy.com/rankings/railway_passengers/ (accessed 10 September 2020); The Global Economy. Railway Transport of Goods_Country Rankings. https://www.theglobaleconomy. com/rankings/Railway_transport_of_goods/ (accessed 10 September 2020); and The Global Economy. Railroad Infrastructure QualityCountry Rankings. https:/www.theglobaleconomy.com/rankings/railroad_quality/(accessed 10 September 2020). 


\section{Contracting Agencies in the Railway Sector}

Pakistan Railways is the national state-owned railway company of Pakistan. The railway company owns $1,881 \mathrm{~km}$ of track across Pakistan and operates freight and passenger service. Pakistan Railways reports to the Ministry of Railways. Overall, the control of Pakistan Railways and policy and development of the railway network are managed and administrated by the Ministry of Railways (footnote 5).

\section{Railway Sector Laws and Regulations}

The Railways Act 1890 and its subsequent amendments are the relevant regulations for railways. In 2002, the government issued the Railway Regulatory Authority Ordinance 2002 to provide for the establishment of the Railway Regulatory Authority. One of the important premises in the Ordinance of 2002 is "to foster competition, encourage and facilitate private sector investment and participation in the development and operation of passenger and goods trains on the railway network, protect the public interest while respecting individual rights and provide effective and efficient regulations." Some of the key functions of the Railway Regulatory Authority are the following: ${ }^{20}$

- to promote the provision of efficient and competitive railway services and approve the terms of track access agreements;

- to prescribe technical standards for the railway infrastructure and the rolling stock, and for testing;

- to require licensees to furnish, on a periodical basis, not less than one year, operating and financial results and other necessary information; and

- to prescribe fines for contravention of the provisions of the Ordinance 2002 and the rules, regulations, decisions, and terms and conditions of a license.

\subsection{Foreign Investment Restrictions in the Railway Sector}

The maximum equity investment allowed for foreign investors in greenfield projects is $100 \%$ (Table 18).

Table 18: Foreign Investment in the Railway Sector

\begin{tabular}{|l|c|c|c|}
\hline Item & 2017 & 2018 & 2019 \\
\hline Maximum allowed foreign ownership of equity in greenfield projects & $100 \%$ & $100 \%$ & $100 \%$ \\
\hline
\end{tabular}

Source: Asian Development Bank. 2019. Public-Private Partnership Monitor. Second Edition. Manila. https://www.adb.org/sites/default/ files/publication/509426/ppp-monitor-second-edition.pdf.

\subsection{Standard Contracts in the Railway Sector}

\begin{tabular}{l|c} 
Type of Contract & Availability \\
\hline Public-private partnership/concession agreement & UA \\
\hline Performance-based operation and maintenance contract & UA \\
\hline Engineering, procurement, and construction contract & UA \\
\hline
\end{tabular}

$\mathrm{UA}=$ Unavailable.

Source: Asian Development Bank.2019. Public-Private Partnership Monitor. Second Edition. Manila. https://www.adb.org/sites/default/ files/publication/509426/ppp-monitor-second-edition.pdf.

20 Nasir Law Associates. 2002. The Railway Regulatory Authority Ordinance, 2002. Islamabad. http://nasirlawsite.com/laws/rrao.htm. 


\section{Railway Sector Master Plan}

According to its publication, Pakistan Railways intends to extensively deploy PPP as a procurement mode across various functions: (i) operations and business development, (ii) rolling stock, (iii) infrastructure development, and (iv) noncore business. The details of the specific projects listed by the Ministry of Railways and the estimated costs and status are presented in Section 1.3.2.3.1. ${ }^{21}$

\section{Projects under Preparation and Procurement in the Railway Sector}

Table 19 provides a list of projects at various stages of preparation and implementation in the railway sector.

Table 19: List of Projects at Various Stages in the Railway Sector

\begin{tabular}{|c|c|c|c|c|}
\hline Name of the Project & $\begin{array}{l}\text { Development } \\
\text { Mode }\end{array}$ & $\begin{array}{l}\text { Estimate } \\
\text { (\$ million) }\end{array}$ & $\begin{array}{l}\text { vestments } \\
\text { (PRs million) }\end{array}$ & Status \\
\hline \multicolumn{5}{|c|}{ A. Business Development and Operations } \\
\hline $\begin{array}{l}\text { 1. Railway Automated Booking } \\
\text { and Travel Assistance System }\end{array}$ & Joint venture & 5.17 & 800 & $\begin{array}{l}\text { Concept approved by PPPA Board; } \\
\text { RFP being prepared }\end{array}$ \\
\hline 2. Track Access Regime & $\begin{array}{c}\text { PPP } \\
\text { (Concession) }\end{array}$ & 41.33 & 6,400 & $\begin{array}{l}\text { Concept was approved by ECC in } \\
\text { 2005; } \\
\text { Approved by PPPA Board }\end{array}$ \\
\hline $\begin{array}{l}\text { 3. Development of Railways } \\
\text { Stations as Commercial hub }\end{array}$ & BOT & 12.92 & 2,000 & $\begin{array}{l}\text { Concept approved by PPPA Board; } \\
\text { PC2 being prepared for TA }\end{array}$ \\
\hline \multicolumn{5}{|l|}{ B. Rolling Stock } \\
\hline 4. Rolling Stock Tracking System & PPP & 1.29 & 200 & $\begin{array}{l}\text { Advertised for inviting private sector; } \\
\text { Concept approved by PPPA Board } \\
\text { as ex post facto }\end{array}$ \\
\hline $\begin{array}{l}\text { 5. Conversion and improvement } \\
\text { of existing freight wagons for } \\
\text { containerized traffic }\end{array}$ & BOT & 25.83 & 4,000 & $\begin{array}{l}\text { Concept approved by PPPA Board; } \\
\text { PC2 being prepared for TA }\end{array}$ \\
\hline $\begin{array}{l}\text { 6. Replacement of } 1,000 \\
\text { passenger coaches }\end{array}$ & Joint venture & 581.21 & 90,000 & $\begin{array}{l}\text { Concept approved by PPPA Board; } \\
\text { PC2 being prepared for TA }\end{array}$ \\
\hline $\begin{array}{l}\text { 7. Induction of 5,000 freight } \\
\text { wagons }\end{array}$ & Joint venture & $2,260.26$ & 350,000 & $\begin{array}{l}\text { Concept approved by PPPA Board; } \\
\text { PC2 being prepared for TA }\end{array}$ \\
\hline
\end{tabular}


Table 19 continued

\begin{tabular}{|c|c|c|c|c|}
\hline Name of the Project & $\begin{array}{l}\text { Development } \\
\text { Mode }\end{array}$ & $\begin{array}{l}\text { Estimate } \\
\text { (\$ million) }\end{array}$ & $\begin{array}{l}\text { vestments } \\
\text { (PRs million) }\end{array}$ & Status \\
\hline \multicolumn{5}{|l|}{ C. Infrastructure Development } \\
\hline $\begin{array}{l}\text { 8. Rail connectivity of Block-II } \\
\text { Thar coal field with existing } \\
\text { railway network (105 km) }\end{array}$ & BOT & 226.03 & 35,000 & $\begin{array}{l}\text { Feasibility in final stages; } \\
\text { TA being procured, advertised; } \\
\text { Concept approved by PPPA Board } \\
\text { ex post facto }\end{array}$ \\
\hline $\begin{array}{l}\text { 9. KPT-Pipri dedicated freight } \\
\text { corridor and model rail freight } \\
\text { terminal }(50 \mathrm{~km})\end{array}$ & BOT & 258.32 & 40,000 & $\begin{array}{l}\text { Concept approved by PPPA Board; } \\
\text { Feasibility study being conducted; } \\
\text { RFP would be issued to six } \\
\text { shortlisted firms }\end{array}$ \\
\hline $\begin{array}{l}\text { 10. New double line from Karachi } \\
\text { (Juma Goth) to Hyderabad } \\
(130 \mathrm{~km})\end{array}$ & BOT & 839.52 & 130,000 & $\begin{array}{l}\text { Concept approved by PPPA Board; } \\
\text { Feasibility study initiated }\end{array}$ \\
\hline $\begin{array}{l}\text { 11. Rail link from Port Qasim } \\
\text { (PIBT) Karachi to Bin Qasim } \\
\text { Station on ML-1 (9 km) }\end{array}$ & BOT & 29.06 & 4,500 & $\begin{array}{l}\text { Concept approved by PPPA Board; } \\
\text { TA being procured, advertised }\end{array}$ \\
\hline $\begin{array}{l}\text { 12. Improvement of rail link (CTR } \\
\text { and signaling) from Kot Adu } \\
\text { and Attock }(425 \mathrm{~km})\end{array}$ & PPP & 193.74 & 30,000 & $\begin{array}{l}\text { Concept approved by PPPA Board; } \\
\text { TA being procured, advertised }\end{array}$ \\
\hline $\begin{array}{l}\text { 13. Improvement of rail link from } \\
\text { Kotri to Jacobabad of ML-2 } \\
(401 \mathrm{~km})\end{array}$ & PPP & 180.82 & 28,000 & $\begin{array}{l}\text { Concept approved by PPPA Board; } \\
\text { TA being procured, advertised }\end{array}$ \\
\hline $\begin{array}{l}\text { 14. Improvement of rail link from } \\
\text { Jacobabad to Kot Adu of ML-2 } \\
(428 \mathrm{~km})\end{array}$ & PPP & 193.74 & 30,000 & $\begin{array}{l}\text { Concept approved by PPPA Board; } \\
\text { TA being procured, advertised }\end{array}$ \\
\hline $\begin{array}{l}\text { 15. Improvement of rail link from } \\
\text { Rohri to Sibi of ML-3 (244 km) }\end{array}$ & PPP & 64.58 & 10,000 & $\begin{array}{l}\text { Concept approved by PPPA Board; } \\
\text { TA being procured, advertised }\end{array}$ \\
\hline $\begin{array}{l}\text { 16. Improvement of rail link } \\
\text { from Sibi to Quetta of ML-3 } \\
(178 \mathrm{~km})\end{array}$ & PPP & 38.75 & 6,000 & $\begin{array}{l}\text { Concept approved by PPPA Board; } \\
\text { TA being procured, advertised }\end{array}$ \\
\hline $\begin{array}{l}\text { 17. Quetta-Chaman Railway } \\
(128 \mathrm{~km})\end{array}$ & PPP & 38.75 & 6,000 & $\begin{array}{l}\text { Concept approved by PPPA Board; } \\
\text { TA being procured, advertised }\end{array}$ \\
\hline $\begin{array}{l}\text { 18. Quetta-Zhob Kotlajam via } \\
\text { DIKhan Railway Section } \\
(536 \mathrm{~km})\end{array}$ & PPP & $1,937.36$ & 300,000 & $\begin{array}{l}\text { Concept approved by PPPA Board; } \\
\text { Feasibility study completed; } \\
\text { PC2 for TA is being prepared }\end{array}$ \\
\hline $\begin{array}{l}\text { 19. Nowshera-Dargai-Swat } \\
\text { (Kalam) }(285 \mathrm{~km})\end{array}$ & PPP & 452.05 & 70,000 & $\begin{array}{l}\text { Concept approved by PPPA Board; } \\
\text { PC2 being prepared for feasibility } \\
\text { study and TA }\end{array}$ \\
\hline $\begin{array}{l}\text { 20. Peshawar-Torkham Rail } \\
\text { Section }(65 \mathrm{~km}) \text { on PPP }\end{array}$ & PPP & 129.16 & 20,000 & $\begin{array}{l}\text { Concept approved by PPPA Board; } \\
\text { Feasibility study in progress }\end{array}$ \\
\hline $\begin{array}{l}\text { 21. Construction and operation of } \\
\text { Railways on PPP }\end{array}$ & PPP & $1,291.58$ & 200,000 & $\begin{array}{l}\text { Concept approved by PPPA Board; } \\
\text { Feasibility study being completed }\end{array}$ \\
\hline
\end{tabular}


Table 19 continued

\begin{tabular}{|c|c|c|c|c|}
\hline Name of the Project & $\begin{array}{l}\text { Development } \\
\text { Mode }\end{array}$ & $\begin{array}{l}\text { Estimatec } \\
\text { (\$ million) }\end{array}$ & $\begin{array}{l}\text { vestments } \\
\text { (PRs million) }\end{array}$ & Status \\
\hline \multicolumn{5}{|l|}{ D. Noncore Business } \\
\hline $\begin{array}{l}\text { 22. PPP for Upgradation and } \\
\text { Rehabilitation of Railway } \\
\text { Hospitals }\end{array}$ & Outsourcing & 29.06 & 4,500 & $\begin{array}{l}\text { Concept approved by PPPA Board; } \\
\text { TA being procured, advertised }\end{array}$ \\
\hline $\begin{array}{l}\text { 23. PPP for Upgradation and } \\
\text { Rehabilitation of Railway } \\
\text { Schools and Colleges }\end{array}$ & Outsourcing & 12.92 & 2,000 & $\begin{array}{l}\text { Concept approved by PPPA Board; } \\
\text { TA hiring is advertised }\end{array}$ \\
\hline $\begin{array}{l}\text { 24. Development of lands through } \\
\text { PPP }\end{array}$ & PPP & 322.89 & 50,000 & $\begin{array}{l}\text { Concept approved by PPPA Board; } \\
\text { PC2 being prepared for TA hiring }\end{array}$ \\
\hline \multicolumn{5}{|l|}{ E. Urban Railways } \\
\hline $\begin{array}{l}\text { 25. Development of Karachi } \\
\text { Circular Railways as modern } \\
\text { urban railways }\end{array}$ & PPP & 581.21 & 90,000 & Concept approved by PPPA Board \\
\hline
\end{tabular}

$\$=$ United States dollar, BOT = build-operate-transfer, CTR = complete track renewal, ECC = Economic Coordination Committee, $\mathrm{km}=$ kilometer, $\mathrm{KPT}=$ Karachi Port Trust, $\mathrm{ML}=$ main line, $\mathrm{PC2}=$ project component 2 (project feasibility report), PIBT = Pakistan International Bulk Terminal Limited, PPP = public-private partnership, PPPA = Public Private Partnership Authority, PRs = Pakistan rupees, RFP = request for proposal, TA = transaction advisor.

Source: Government of Pakistan, Ministry of Railways. PPP Projects. http://www.railways.gov.pk/Sitelmage/Misc/files/PPP\%20 Project\%20List.pdf (accessed 1 September 2020).

Figure 16 shows the number of projects in Pakistan that are at preparation and procurement stage.

Figure 16: Public-Private Partnership Railway Projects under Preparation and Procurement

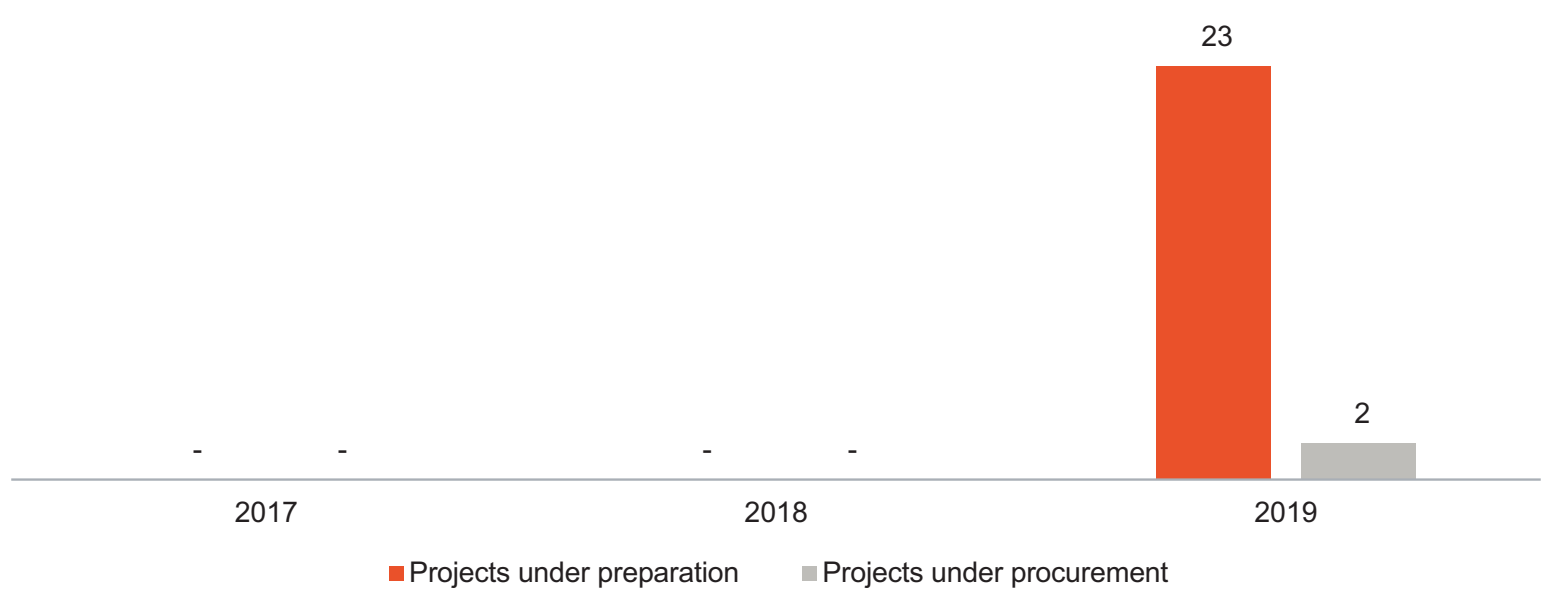

Note: The hyphen symbol (-) means there are no projects in the sector, or data are unavailable, or not applicable.

Source: Asian Development Bank. 2019. Public-Private Partnership Monitor. Second Edition. Manila. https://www.adb.org/ sites/default/files/publication/509426/ppp-monitor-second-edition.pdf; and Government of Pakistan, Ministry of Railways. PPP Projects. http://www.railways.gov.pk/Sitelmage/Misc/files/PPP\%20Project\%20List.pdf. 


\section{Features of Past Public-Private Partnership Projects in the Railway Sector}

There were no projects in the railway sector in the past that were taken up on PPP as per the World Bank PPI database.

There are currently no PPP projects under procurement for the railway sector in Pakistan. It is worth noting that the procurement strategy for the Karachi to Punjab railway was subject to a dispute between the Pakistan's Railway Ministry and the Infrastructure Project Development Facility (IPDF) in 2014. According to the IJGlobal database, in the end, the project was funded by the public sector (footnote 5).

In addition to the above, only the Kahna Kacha Flyover project reached financial closure in the railway sector between 1990 and 2017. The Kahna Kacha Flyover is located at Railway Line Crossing Defence Road at Kahna Kacha Railway Station and is part of the Lahore Urban Transport Master Plan 2011-2030. An unsolicited proposal for developing this flyover in a PPP mode was submitted by M/s ZKB \& Reliable JV to the Lahore Development Authority in August 2013. The estimated cost of the project is PRs2.28 billion in exchange for a 25-year concession to toll traffic at a base rate of PRs0.30 for cars. The project has been operational since 22 June 2016 (footnote 5).

However, the Kahna Kacha Flyover project is not covered under the World Bank PPI database and has therefore not been considered in the charts below. Figure 17 presents the number of PPP projects in Pakistan's railway sector procured through various modes including direct appointment, unsolicited bids, and competitive bids.

Figure 17: Modes of Procurement for Public-Private Partnership Railway Projects

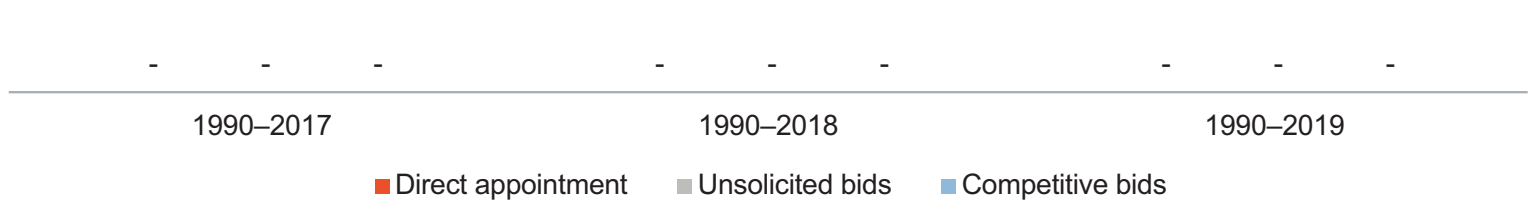

Note: Only active and concluded projects are considered in the above graph. The hyphen symbol (-) means there are no projects in the sector, or data are unavailable, or not applicable according to the database.

Source: World Bank. Infrastructure Finance, PPPs and Guarantees. Country Snapshots. Pakistan. https://ppi.worldbank.org/en/ snapshots/country/pakistan (accessed 1 September 2020). 
Figure 18 shows the number of PPP projects that have reached financial closure, and the total value of those projects in Pakistan's railway sector.

\section{Figure 18: Public-Private Partnership Railway Projects Reaching Financial Closure}

0

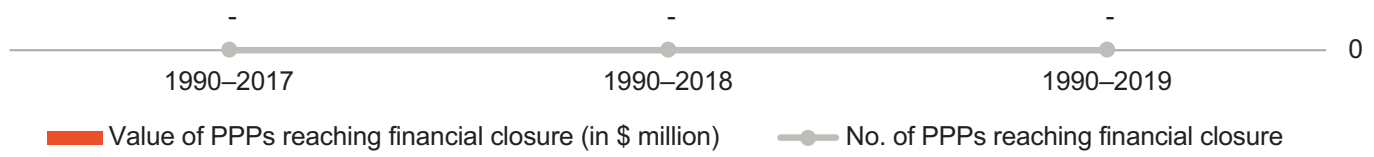

$\$=$ United States dollar, PPP = public-private partnership.

Note: Only active and concluded projects are considered in the above graph. The hyphen symbol (-) means there are no projects in the sector, or data are unavailable, or not applicable according to the database.

Source: World Bank. Infrastructure Finance, PPPs and Guarantees. Country Snapshots. Pakistan. https://ppi.worldbank.org/en/ snapshots/country/pakistan (accessed 1 September 2020).

Figure 19 presents the number of PPP projects that have received foreign sponsor participation in Pakistan's railway sector.

\section{Figure 19: Public-Private Partnership Railway Projects with Foreign Sponsor Participation}

0

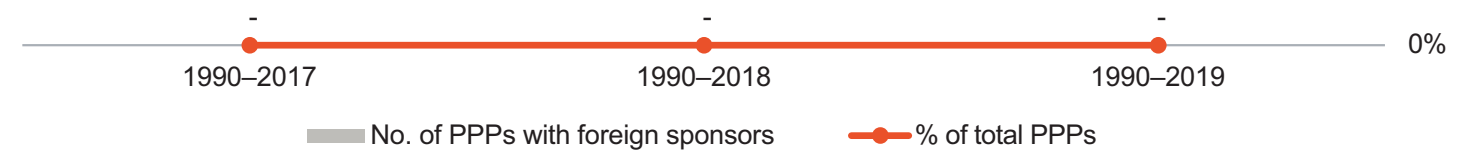

PPP = public-private partnership.

Note: Only active and concluded projects are considered in the above graph. The hyphen symbol (-) means there are no projects in the sector, or data are unavailable, or not applicable according to the database.

Source: World Bank. Infrastructure Finance, PPPs and Guarantees. Country Snapshots. Pakistan. https://ppi.worldbank.org/en/ snapshots/country/pakistan (accessed 1 September 2020). 
Figure 20 presents the number of PPP projects that have received government support, including the VGF mechanism, government guarantees, and availability or performance payment in Pakistan's railway sector.

Figure 20: Government Support to Public-Private Partnership Railway Projects

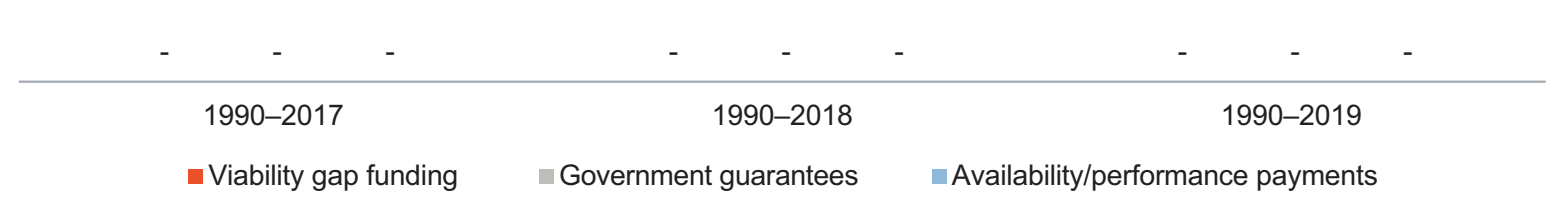

Note: Only active and concluded projects are considered in the above graph. The hyphen symbol (-) means there are no projects in the sector, or data are unavailable, or not applicable according to the database.

Source: World Bank. Infrastructure Finance, PPPs and Guarantees. Country Snapshots. Pakistan. https://ppi.worldbank.org/en/ snapshots/country/pakistan (accessed 1 September 2020).

Figure 21 shows the number of PPP projects that have received payment in the form of user charges and government pay (off-take) in Pakistan's railway sector.

Figure 21: Payment Mechanism for Public-Private Partnership Railway Projects

\begin{tabular}{|c|c|c|}
\hline- & - & - \\
\hline \multirow[t]{2}{*}{ 1990-2017 } & 1990-2018 & 1990-2019 \\
\hline & Governme & \\
\hline
\end{tabular}

Note: Only active and concluded projects are considered in the above graph. The hyphen symbol (-) means there are no projects in the sector, or data are unavailable, or not applicable according to the database.

Source: World Bank. Infrastructure Finance, PPPs and Guarantees. Country Snapshots. Pakistan. https://ppi.worldbank.org/en/ snapshots/country/pakistan (accessed 1 September 2020). 


\subsection{Tariffs in the Railway Sector}

There is no information available regarding railway sector tariffs.

\subsection{Typical Risk Allocation for Public-Private Partnership Projects in the Railway Sector}

The information on typical risk allocation for PPP projects in Pakistan's railway sector is unavailable.

\subsection{Financing Details of Public-Private Partnership Projects in the Railway Sector}

As no PPP projects in the railway sector have achieved financial closure till 2019, there is no information available on the financing details (Table 20).

Table 20 presents the financing details of PPP railway sector projects in Pakistan.

Table 20: Financing of Public-Private Partnership Projects in the Railway Sector

\begin{tabular}{|l|c|c|}
\hline Item & 1990-2017 & 1990-2018 \\
\hline PPP projects with foreign lending participation & NA 019 \\
\hline $\begin{array}{l}\text { PPP projects that received export credit agency/international } \\
\text { financing institution support }\end{array}$ & NA & NA \\
\hline Typical debt-equity ratio & NA \\
\hline Time for financial closure & NA \\
\hline Typical concession period & NA \\
\hline Typical financial internal rate of return & NA \\
\hline
\end{tabular}

NA = not applicable, $P P P=$ public-private partnership.

Source: World Bank. Infrastructure Finance, PPPs and Guarantees. Country Snapshots. Pakistan. https://ppi.worldbank.org/en/ snapshots/country/pakistan (accessed 1 September 2020).

\section{Challenges in the Railway Sector}

The role of Pakistan Railways as a catalyst for economic development experienced a setback due to significant under-investment by successive governments, who preferred investment in road infrastructure at the cost of Pakistan Railways (footnote 5).

\section{PORTS}

Number, capacity, and quality of port infrastructure projects are presented in Table 21.

Table 21: Status of Port Infrastructure Projects

\begin{tabular}{|l|r|c|}
\hline Item & \multicolumn{2}{c|}{ Value } \\
\hline Total no. of ports & 3 & no. \\
\hline Total freight capacity of all the ports & 89.85 & MTPA \\
\hline Total container traffic at ports & $3,275,000$ & TEU \\
\hline Quality of port infrastructure & 4.0 & 1 (low) - 7 (high) \\
\hline
\end{tabular}


Table 21 continued

Item

Quality of trade and transport-related infrastructure index
Value

2.7
Unit

1 (low) -5 (high)

MTPA = million tons per annum, TEU = twenty-feet equivalent unit.

a Pertains to the period 2016-2017.

Sources: Government of Pakistan, Ministry of Maritime Affairs. 2017. Year Book 2016-2017. Islamabad. https://moma.gov.pk/ Sitelmage/Misc/files/YB_2016-17.pdf; The Economist Intelligence Unit. Infrascope 2018: Pakistan Country Profile. https://infrascope. eiu.com (accessed 10 September 2020); The Global Economy. Port Traffic-Country Rankings. https://www.theglobaleconomy. com/rankings/Port_traffic/ (accessed 10 September 2020); and World Port Source. World Ports by Country-Pakistan. http://www. worldportsource.com/countries.php (accessed 10 September 2020).

\section{Contracting Agencies in the Port Sector}

The Ministry of Maritime Affairs, previously named the Ministry of Port and Shipping, is the main authority of the port sector. It is the ministry's role to declare and delimit the major ports and the constitution and power of authorities in the following ports: Karachi Port Trust, Port Bin Qasim, and Gwadar Port. The ministry also maintains technical control and regulates the functioning of subordinate organizations, Karachi Port Trust, Port Bin Qasim, Gwadar Port, and the Pakistan National Shipping Corporation (footnote 5).

\section{Port Sector Laws and Regulations}

In 2001, the Pakistan Merchant Shipping Ordinance 2001 replaced the Merchant Shipping Act of 1923, to reflect the fact that Pakistan became a member of the International Labour Organization, upholding the maritime labor international standards. This provides a framework and rules under which the government authorities will function in dealing with matters related to the shipping industry (footnote 5).

Some ports have a special status. In 2017, for example, the Federal Board of Revenue decided to grant exemption of taxes for projects related to Gwadar, including the Gwadar International Airport, under the China-Pakistan Economic Corridor (CPEC) project. In the past, the Economic Coordination Committee of the cabinet approved a grant for tax exemption to those establishing businesses in the free zone for a period of 23 years. The grant was issued under the Gwadar Port Concession Agreement for the operation and development of Gwadar Port (footnote 5).

The Ministry of Maritime Affairs in Islamabad is the central administrative authority of the federal government, primarily assigned to facilitate the ports and shipping industry of Pakistan. It provides policy guidelines to encourage port development and growth in shipping while maintaining safety standards. ${ }^{22}$

The Office of Directorate General Ports and Shipping works as a wing of the Ministry of Maritime Affairs specifically on administrative matters related to the ports and its authorities. It provides policy input on matters related to ports and shipping, administers the merchant shipping in the country, adheres to international maritime conventions, issues certificate of competence for Master Mariners, frames rules, and approves the training syllabus, among others. The Karachi Port Trust, Port Qasim Authority, Pakistan National Shipping Corporation, and Gwadar Port Authority are autonomous organizations with their own fully empowered Boards of Directors and stipulated rules and regulations (footnote 5).

22 Government of Pakistan, Ministry of Maritime Affairs. https://moma.gov.pk/Detail/NzIxMTIzM2EtMjQwOCO0MjUyLTIhOTctMTViNzVkYzA2Nmly. 


\subsection{Foreign Investment Restrictions in the Port Sector}

The maximum equity investment allowed for foreign investors in greenfield projects is 100\% (Table 22).

Table 22: Foreign Investment in the Port Sector

\begin{tabular}{|l|c|c|c|c|}
\hline Item & 2017 & 2018 & 2019 \\
\hline Maximum allowed foreign ownership of equity in greenfield projects & $100 \%$ & $100 \%$ & $100 \%$ \\
\hline
\end{tabular}

Source: Asian Development Bank. 2019. Public-Private Partnership Monitor. Second Edition. Manila. https://www.adb.org/sites/default/ files/publication/509426/ppp-monitor-second-edition.pdf.

\subsection{Standard Contracts in the Port Sector}

\begin{tabular}{|l|c|}
\hline Type of Contract & Availability \\
\hline Public-private partnership/concession agreement & UA \\
\hline Performance-based operation and maintenance contract & UA \\
\hline Engineering, procurement, and construction contract & UA \\
\hline
\end{tabular}

$\mathrm{UA}=$ Unavailable.

Source: Asian Development Bank. 2019. Public-Private Partnership Monitor. Second Edition. Manila. https://www.adb.org/sites/default/ files/publication/509426/ppp-monitor-second-edition.pdf.

\section{Port Sector Master Plan}

The Maritime Yearbook 2016-2017 provides a list of major projects being planned by the Karachi Port Authority. A further update of the yearbook is unavailable. As per the yearbook, in 2015, the Karachi Port Authority prepared a 10-year business plan and strategic development plan, outlining the following major projects:

- environment friendly multipurpose bulk handling terminal at East Wharf,

- construction of peripheral road along Chinna Creek,

- development of TPX Area (as dry port) along M. T. Khan Road (proposed to be taken up on PPP),

- construction of elevated port expressway (proposed to be taken up on PPP),

- reconstruction of OP-I facility,

- cable-stayed bridge/Karachi Harbour Crossing at the Port of Karachi (proposed to be taken up on PPP), and

- cargo village/industrial park over 1,300 acres of land (proposed to be taken up on PPP).

Similarly, there were ongoing projects taken up by the ports of Gwadar and Qasim, as highlighted in the yearbook. 


\section{Projects under Preparation and Procurement in the Port Sector}

Figure 22 reflects the number of projects under preparation and procurement in Pakistan's port sector.

Figure 22: Public-Private Partnership Port Projects under Preparation and Procurement

2017

$-$

2018

2019

- Projects under preparation $\quad$ Projects under procurement

Note: The hyphen symbol (-) means there are no projects in the sector, or data are unavailable, or not applicable.

Source: Asian Development Bank. 2019. Public-Private Partnership Monitor. Second Edition. Manila. https://www.adb.org/sites/ default/files/publication/509426/ppp-monitor-second-edition.pdf.

\section{Features of Past Public-Private Partnership Projects in the Port Sector}

The projects that achieved financial closure in the port sector are as follows:

- Port Mohammed bin Qasim Liquid Bulk Terminal, 1995;

- Qasim International Container Terminal, 1995;

- Karachi International Container Terminal, 1997;

- Pakistan International Container Terminal, 2002;

- Gwadar Port Phase II, 2007;

- Qasim Grain and Fertilizer Terminal, 2008;

- Second Container Terminal at Port Mohammad Qasim, 2008;

- Pakistan Deep Water Container, 2010; and

- Pakistan Deep Water Container Port Phase II, 2019. 
Figure 23 shows the number of PPP projects in Pakistan's port sector, procured through various modes, including direct appointment, unsolicited bids, and competitive bids.

Figure 23: Modes of Procurement for Public-Private Partnership Port Projects

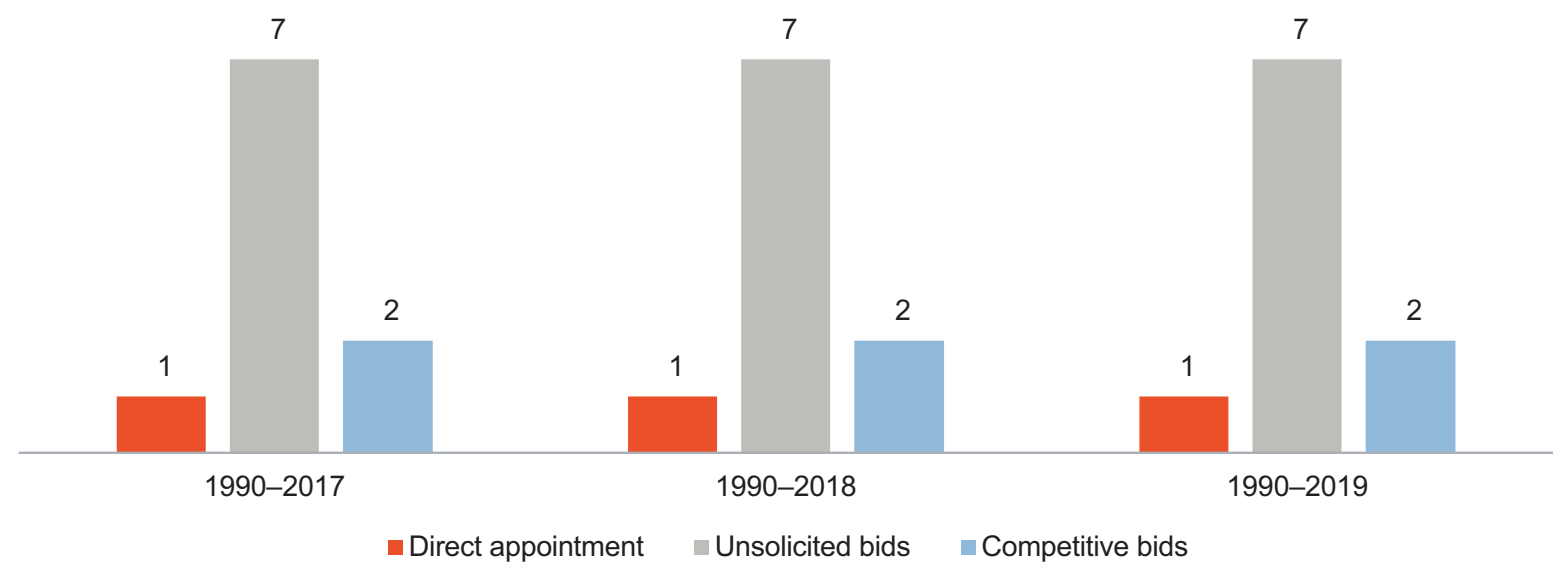

Note: Only active and concluded projects are considered in the above graph

Source: World Bank. Infrastructure Finance, PPPs and Guarantees. Country Snapshots. Pakistan. https://ppi.worldbank.org/en/ snapshots/country/pakistan (accessed 1 September 2020).

Figure 24 presents the number of PPP projects that have reached financial closure, and the total value of those projects in Pakistan's port sector.

\section{Figure 24: Public-Private Partnership Port Projects Reaching Financial Closure}

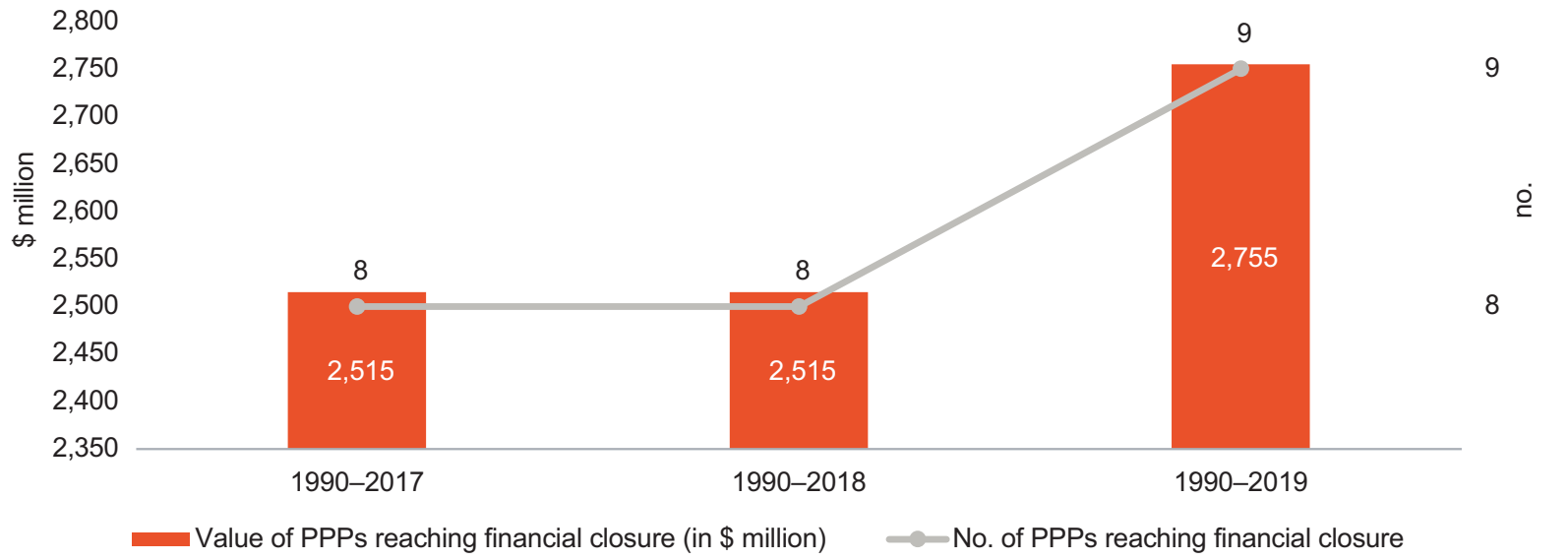

\$ = United States dollar, PPP = public-private partnership.

Note: Only active and concluded projects are considered in the above graph.

Source: World Bank. Infrastructure Finance, PPPs and Guarantees. Country Snapshots. Pakistan. https://ppi.worldbank.org/en/ snapshots/country/pakistan (accessed 1 September 2020). 
Figure 25 shows the number of PPP projects that have received foreign sponsor participation in Pakistan's port sector.

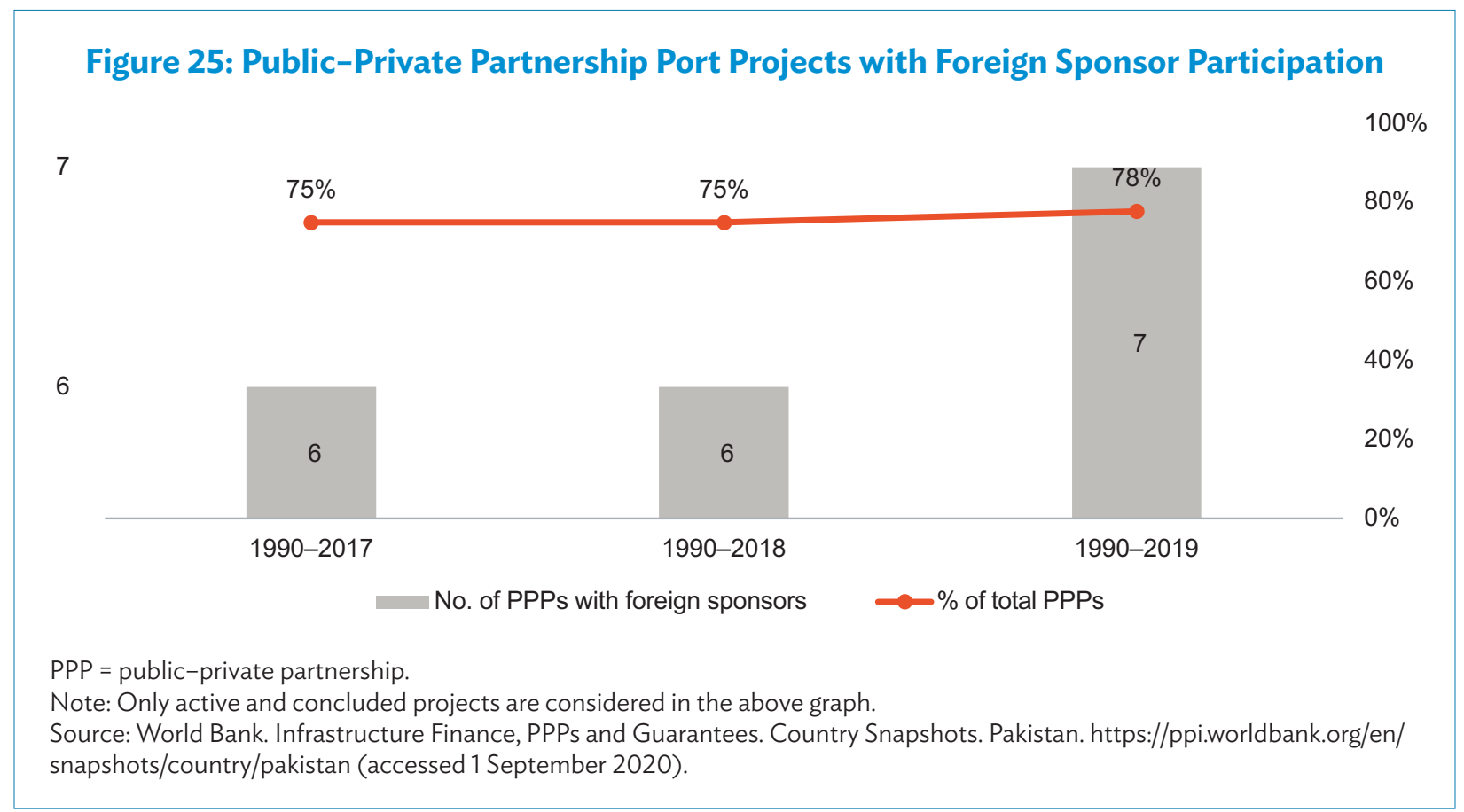

Figure 26 presents the number of PPP projects in Pakistan's port sector that have received government support, including the VGF mechanism, government guarantees, and availability or performance payment.

Figure 26: Government Support to Public-Private Partnership Port Projects

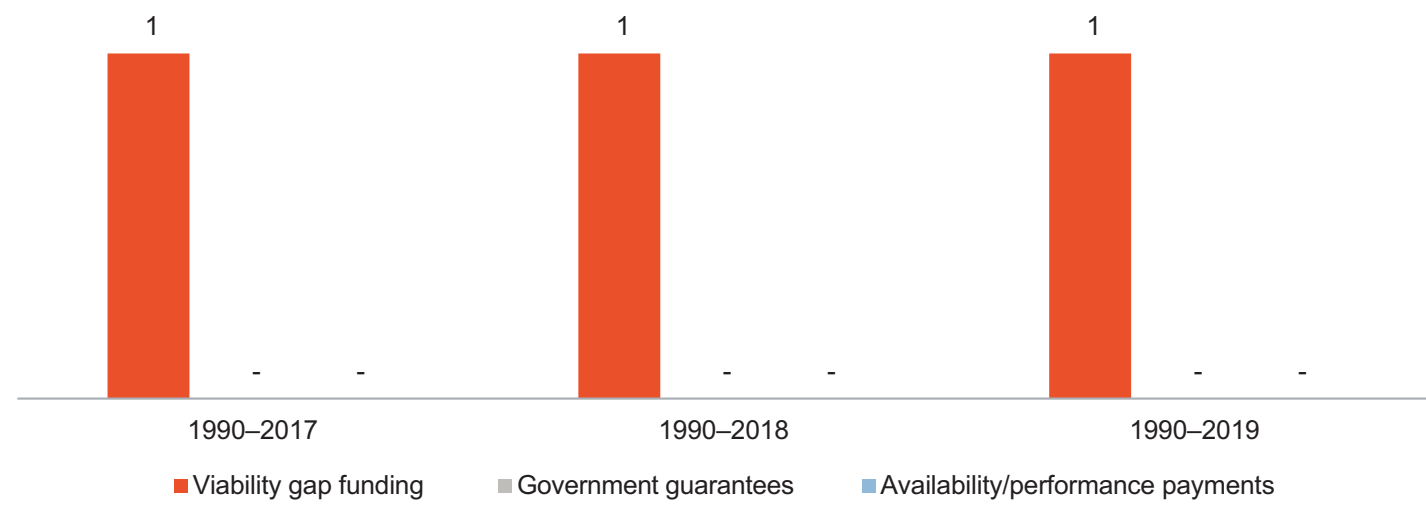

Note: Only active and concluded projects are considered in the above graph. The hyphen symbol (-) means there are no projects in the sector, or data are unavailable, or not applicable according to the database.

Source: World Bank. Infrastructure Finance, PPPs and Guarantees. Country Snapshots. Pakistan. https://ppi.worldbank.org/en/ snapshots/country/pakistan (accessed 1 September 2020). 
Figure 27 provides the number of PPP projects in Pakistan's port sector that have received payment in the form of user charges and government pay (off-take).

Figure 27: Payment Mechanism for Public-Private Partnership Port Projects

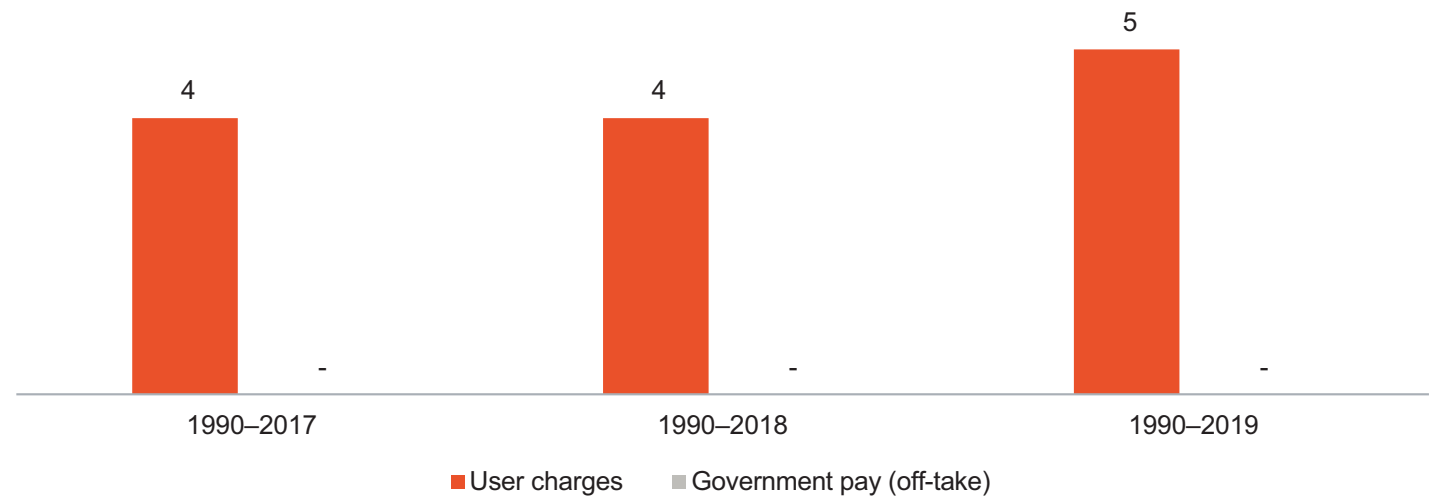

Note: Only active and concluded projects are considered in the above graph. The hyphen symbol (-) means there are no projects in the sector, or data are unavailable, or not applicable according to the database.

Source: World Bank. Infrastructure Finance, PPPs and Guarantees. Country Snapshots. Pakistan. https://ppi.worldbank.org/en/ snapshots/country/pakistan (accessed 1 September 2020).

\subsection{Tariffs in the Port Sector}

There is no available information on tariffs in the port sector.

\subsection{Typical Risk Allocation for Public-Private Partnership Projects in the Port Sector}

Table 23 presents the risk allocation to the public and private sectors for PPP port projects in Pakistan by type of risk.

Table 23: Risk Allocation of Public-Private Partnership Projects in the Port Sector

\begin{tabular}{|l|c|c|c|c|}
\hline Risk Type & Private & Public & Shared & \multicolumn{1}{c|}{ Comment } \\
\hline Demand risk & $\checkmark$ & & & \\
\hline Competition risk (exclusivity) & & $\checkmark$ & & \\
\hline Tariff implementation or escalation risk & & & $\checkmark$ & \\
\hline Environmental and social risk & & & $\checkmark$ & \\
\hline Permits & & & $\checkmark$ & \\
\hline Geotechnical risk & $\checkmark$ & & & \\
\hline
\end{tabular}

Source: Asian Development Bank.

\subsection{Financing Detaills of Public-Private Partnership Projects in the Port Sector}

Table 24 presents the financing details of PPP port sector projects in Pakistan. 
Table 24: Financing of Public-Private Partnership Projects in the Port Sector

\begin{tabular}{|l|c|c|}
\hline Item & 1990-2017 & 1990-2018 \\
\hline PPP projects with foreign lending participation & $\ldots$ & $\ldots$ \\
\hline $\begin{array}{l}\text { PPP projects that received export credit agency/international financing } \\
\text { institution support (no.) }\end{array}$ & 2 & 2 \\
\hline Typical debt-equity ratio & $\ldots$ \\
\hline Time for financial closure & $\ldots$ \\
\hline Typical concession period & $\ldots$ \\
\hline Typical financial internal rate of return & 21 years \\
\hline
\end{tabular}

$\ldots=$ data not available, PPP = public-private partnership.

Note: Only active and concluded projects are considered in the table above.

a Includes both foreign bank lending and international financial institution support.

Source: World Bank. Infrastructure Finance, PPPs and Guarantees. Country Snapshots. Pakistan. https://ppi.worldbank.org/en/ snapshots/country/pakistan (accessed 1 September 2020).

\section{Challenges in the Port Sector}

Currently, infrastructure development in Pakistan's port sector is led by the regional strategy of the People's Republic of China (PRC). The CPEC initiative and details of the agreement with the PRC authorities have brought some issues and challenges in the port sector. As an example, as per the Gwadar Port Concession Agreement, the China Overseas Port Holding Company has 91\% share in the gross revenue of terminal and marine operations and $85 \%$ share in the gross revenue from operations of the free zone (footnote 5 ).

\section{AIRPORTS}

Number, capacity, and quality of airport infrastructure projects are presented in Table 25.

Table 25: Status of Airport Infrastructure Projects

\begin{tabular}{|l|r|c|}
\hline Item & Value & Unit \\
\hline No. of airports & 62 & no. \\
\hline Total passenger capacity & 6.88 & million passengers \\
\hline Quality of air transport infrastructure & 4.20 & 1 (low) - 7 (high) \\
\hline $\begin{array}{l}\text { Total no. of projects with cumulative lending, grant, and technical assistance } \\
\text { commitments in the transport sector }\end{array}$ & 86 & no. \\
\hline $\begin{array}{l}\text { Total amount of cumulative lending, grant, and technical assistance } \\
\text { commitments in the transport sector }\end{array}$ & 5,492 & $\$$ million \\
\hline
\end{tabular}

Sources: Asian Development Bank. Data Library. Cumulative Lending, Grant, and Technical Assistance Commitments. https:// data.adb.org/dataset/cumulative-lending-grant-and-technical-assistance-commitments (accessed 2 December 2020); City Population. Airports. https://www.citypopulation.de/en/world/bymap/airports.html (accessed 2 December 2020); The Airport Authority. List of All Airports in Pakistan. https://airport-authority.com/browse-PK (accessed 2 December 2020); The Global Economy. Compare Countries. https://www.theglobaleconomy.com/compare-countries/ (accessed 10 September 2020); and World Bank. Data. Air Transport Passengers Carried. https://data.worldbank.org/indicator/is.air.psgr?locations=bd-kh-ge-kz-mmpk-pg-lk-uz-vn-cn-in-id-ph-th (accessed 2 December 2020). 


\section{Contracting Agencies in the Airport Sector}

The Pakistan Civil Aviation Authority (PCAA) is the contracting authority for PPPs in the airport and aviation sector.

The Pakistan Civil Aviation Ordinance 1982 empowers the PCAA to award contracts for construction, maintenance, and operation of airports, among other things.

The following departments and organizations are within the purview of the Aviation Division:

- PCAA,

- Pakistan International Airlines Corporation,

- Airport Security Force, and

- Pakistan Meteorological Department.

The Civil Aviation Ordinance 1960 provides the federal government the control of manufacture, possession, use, operation, sale, import and export of aircraft; the control and regulation of air traffic services; and the control and development of aerodromes in Pakistan (footnote 5).

The 1982 Ordinance was passed to establish the PCAA which is mandated to promote and regulate civil aviation activities, and develop infrastructure for safe, efficient, adequate, economical, and properly coordinated civil aviation transport services in Pakistan (footnote 5).

On the other hand, the 1960 Ordinance empowers the federal government to make rules for maintenance, licensing, and regulation of airports, and charge fees for the use of, and for services provided at airports, among other things. Pursuant to the 1982 Ordinance, the PCAA, a public sector autonomous body, oversees and regulates all aspects of civil aviation in Pakistan (footnote 5).

The Aviation Division spearheads strategy, policy, and oversight of all matters related to civil aviation. The key objectives of the division include the following: ${ }^{23}$

- Improve governance and oversight for the compliance of International Civil Aviation Organization standards of aviation safety, security, and efficiency;

- Provide a level playing field for national airlines and liberalize the aviation sector in the country by allowing market forces to determine the price, quality, frequency, and range of air services options;

- Follow suitable PPP models for the operations, management, and development of airports;

- Develop state-of-the-art infrastructure to provide safe and efficient air transportation;

- Incentivize aviation sector for socioeconomic growth; and

- Create conditions conducive for affordable general aviation activities (i.e., sports flying; intercity air travel by private aircraft, air taxi service, or charters).

The Rules of Business 1973 assigns the following functions to the Aviation Division (footnote 23):

- Aircraft and air navigation, administration of the Civil Aviation Ordinance 1960 (XXXII 1960);

- Development of civil aviation in Pakistan;

23 Government of Pakistan, Aviation Division. http://aviation.gov.pk/Overview. 
- Provision of aerodromes;

- Oversight of the Airports Development Agency;

- Regulation, organization, and safety of air traffic and of aerodromes; administration of the Airport Security Force;

- Oversight of the Pakistan International Airlines Corporation Limited;

- Air service agreements with other countries; liaison with the International Civil Aviation Organization and other international agencies concerned with aviation; and

- Meteorological observations in collaboration with both federal and world meteorological organizations.

In 2017, a misunderstanding happened between the Privatization Commission and the PCAA. The PCAA directly issued request for proposals from prospective investors for outsourcing the operation, management, and development of the New Islamabad International Airport, Lahore's Allama lqbal International Airport, and Karachi's Jinnah International Airport. Even though the PCAA is part of the government's privatization program, it is not among the entities that have been picked for early privatization. Section 25 of the Privatization Commission Ordinance of 2000 states the modes by which the Privatization Commission will take decisions on matters pertaining to privatization, restructuring, and deregulation (Section 5 of the Privatization Commission Ordinance of 2000 empowers the Commission to take such decisions).

Pakistan's privatization program started in 1991. It aims to attract private sector capital and managerial expertise through the divestment of identified public sector entities. On 28 September 2000, the Privatization Commission Ordinance 2000 was promulgated, and the Privatization Commission was converted into a corporate body, which strengthened its legal authority for implementing the government's privatization policy (footnote 5).

The Economic Oversight Cell under the Director General of Civil Aviation aims to achieve a balance between the interests of Airports Services and Air Navigation Service Providers, including government-operated providers and their public policy objectives. The National Aviation Policy 2019 states that, "As the involvement of private sector for the operation and management of airports is being encouraged, therefore, the role of Economic Oversight will assume greater significance. It will also oversee financial stability of airlines and other related issues including airline mergers, acquisitions, domestic and international code-share alliances and other joint venture agreements, immunized international alliances between Pakistani and foreign carriers and biases or preferential routing, frequency allocation, slots, etc. allocated to airlines, thus ensuring a fair and competitive environment, in the larger interest of passengers and other stakeholders." 24

\section{Airport Sector Laws and Regulations}

In 2015, the National Aviation Policy was formulated in consultation with all stakeholders representing the various segments of the aviation industry, and through a series of deliberations at the PCAA and Aviation Division. The policy serves as a roadmap for the implementation of safety, security, and quality standards. It also engenders bilateral liberalization; lowering taxes; stimulating economy through tourism, trade, and agriculture; PPP; and infrastructure development (footnote 5). This policy has been replaced with the National Aviation Policy 2019.

In 2019, the government issued the National Aviation Policy which aims to induce competitiveness in the industry and enhance regional air connectivity. One of the objectives of the National Aviation Policy is to "ensure safe, secure, efficient and a commercially viable aviation sector, including aircraft design/manufacturing, and to develop state-of-the-art infrastructure, which contributes positively towards the national economy" (footnote 24).

24 Government of Pakistan, Pakistan Civil Aviation Authority. 2019. National Aviation Policy 2019. Karachi. https://www.caapakistan.com.pk/upload/AT/ NAP-2019.pdf. 
The National Aviation Policy 2019 of Pakistan states,

[The] PCAA may enter into suitable public-private partnership (PPP) models for operation, management and development of these airports. Equity partnership models would be preferable with mandatory management-level local employment for growth of in-country talent and knowledge base.

For major airports, these PPP models would also be followed to improve revenue streams and quality of services. The airport's terminal side may be outsourced to world class operators of international standing through transparent and competitive bidding. Appropriate consultants shall be hired for outsourcing of such facilities at airports. PCAA shall yield revenue either in shape of annual fee structure or through appropriate equity partnership models (footnote 24 ).

The policy further states that,

- The private sector will also be encouraged to construct and/or operate new or existing airports, airstrips, helipads, heliports, including cargo complexes on BOO or BOT basis or any other suitable PPP arrangements, and to raise non-aeronautical revenues from these premises.

- Operators and interested parties for the development and facilitation of aviation sector will be provided [with] open spaces, if available, both on the airside and/or land side at rationalized rates to develop engineering, operational infrastructure, and other allied or supporting facilities.

- For the purpose of promotion of tourism, including religious tourism, PPP model would be followed to establish small strips and helipads close to targeted locations of important and far-flung or inaccessible tourism areas, to ensure air connectivity from trunk, primary stations, and/or routes.

- The PCAA shall formulate policy to make it commercially viable for private investors and provincial governments without jeopardizing aviation activities.

- The development of greenfield and brownfield airports in the private sector shall be encouraged. The PCAA shall promulgate easy and friendly procedure to attract private sector toward developing greenfield airports. The Civil Aviation Authority may provide incentives for the private investor.

- Private sector investors shall be encouraged to develop supporting infrastructure, like airstrips for greenfield airports outside the control zone area.

- Liberalized guidelines shall be formulated in consultation with users to promote and encourage private investment in flying clubs, air taxi service, private ownership of aircraft, including helicopters and gyrocopters, airships, light sports aircraft, amphibian aircraft and aero-sports activities (i.e., hang gliding, ballooning, heli-skiing, and para jumping) (footnote 24).

\subsection{Foreign Investment Restrictions in the Airport Sector}

The maximum equity investment allowed for foreign investors in greenfield projects is $100 \%$ (Table 26).

Table 26: Foreign Investment in the Airport Sector

\begin{tabular}{|l|c|c|c|}
\hline Item & $\mathbf{2 0 1 7}$ & $\mathbf{2 0 1 8}$ & $\mathbf{2 0 1 9}$ \\
\hline Maximum allowed foreign ownership of equity in greenfield projects & $100 \%$ & $100 \%$ & $100 \%$ \\
\hline
\end{tabular}

Source: Asian Development Bank. 2019. Public-Private Partnership Monitor. Second Edition. Manila. https:/www.adb.org/sites/default/ files/publication/509426/ppp-monitor-second-edition.pdf. 


\subsection{Standard Contracts in the Airport Sector}

\begin{tabular}{|l|c|}
\hline Type of Contract & Availability \\
\hline Public-private partnership/concession agreement & UA \\
\hline Performance-based operation and maintenance contract & UA \\
\hline Engineering, procurement, and construction contract & UA \\
\hline
\end{tabular}

UA = Unavailable.

Source: Asian Development Bank. 2019. Public-Private Partnership Monitor. Second Edition. Manila. https://www.adb.org/sites/default/ files/publication/509426/ppp-monitor-second-edition.pdf.

\section{Airport Sector Master Plan}

The National Aviation Policy 2019 states that the available land at all major airports especially at Lahore, Islamabad, and Karachi shall be given to private companies through competitive bidding process to develop facilities, such as perishable facility; cold chain facility; and common facility for housing banks, freight forwarders, and shipping agencies (footnote 24).

The PPP model will also be encouraged for the development of cargo facilities. All major international airports shall be promoted as transshipment hubs through the development of requisite infrastructure.

No further details on specific projects are available.

\section{Projects under Preparation and Procurement in the Airport Sector}

Figure 28 indicates the number of projects in the airport sector that are under preparation and procurement.

Figure 28: Public-Private Partnership Airport Projects under Preparation and Procurement

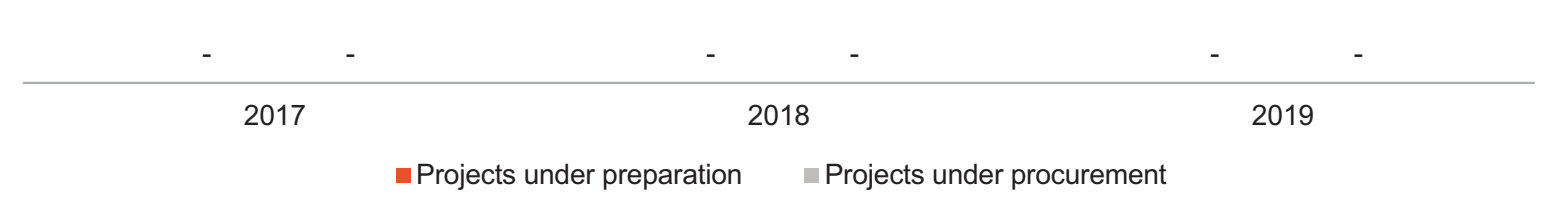

Note: The hyphen symbol (-) means there are no projects in the sector, or data are unavailable. Source: Asian Development Bank. 2019. Public-Private Partnership Monitor. Second Edition. Manila. https://www.adb.org/sites/ default/files/publication/509426/ppp-monitor-second-edition.pdf.

\section{Features of Past Public-Private Partnership Projects in the Airport Sector}

The Sialkot International Airport is the first PPP project in the aviation sector. The project reached financial closure in 2006. It was designed to accommodate around 143,000 passengers a year. The airport mainly offers the opportunity for increased exports, as the Sialkot belongs to the Export Triangle of Pakistan (together with Gujrat and Gujranwala). Traders previously had to send their merchandise through Karachi and Lahore (footnote 5). 
Figure 29 shows the number of PPP projects in Pakistan's airport sector, procured through various modes, including direct appointment, unsolicited bids, and competitive bids.

Figure 29: Modes of Procurement for Public-Private Partnership Airport Projects

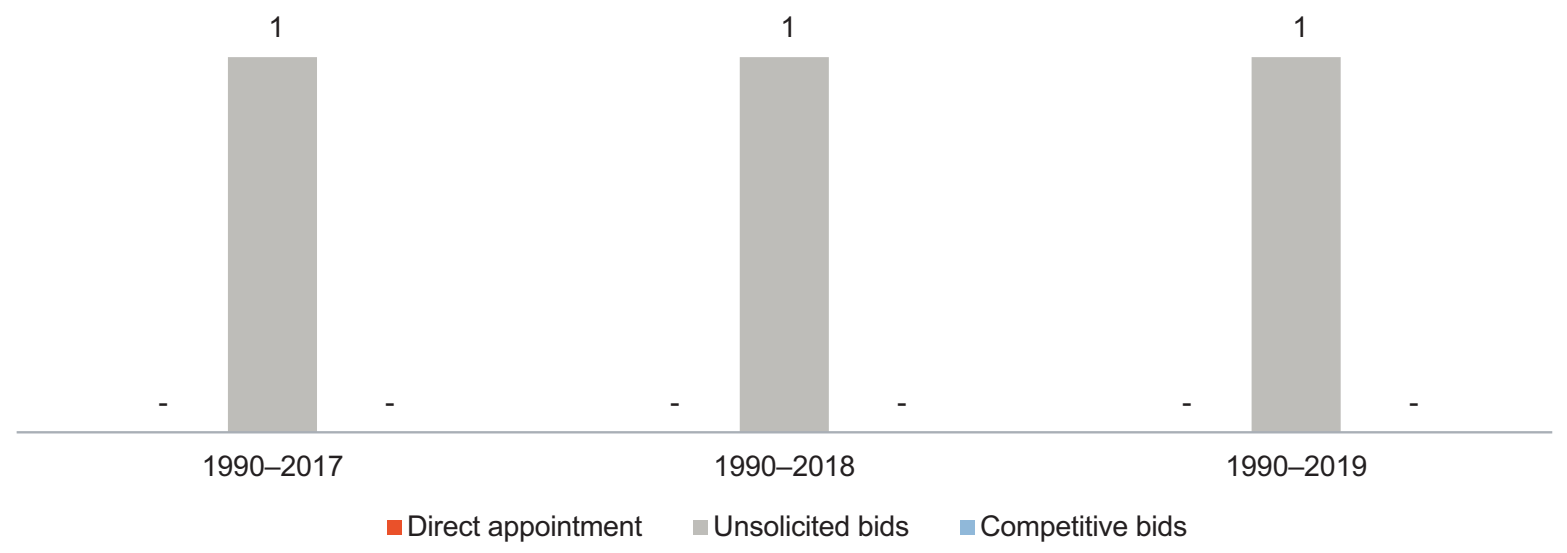

Note: Only active and concluded projects are considered in the above graph. The hyphen symbol (-) means there are no projects in the sector, or data are unavailable, or not applicable according to the database.

Source: World Bank. Infrastructure Finance, PPPs and Guarantees. Country Snapshots. Pakistan. https://ppi.worldbank.org/en/ snapshots/country/pakistan (accessed 1 September 2020).

Figure 30 presents the number of PPP projects in Pakistan's airport sector that have reached financial closure, and the total value of those projects.

Figure 30: Public-Private Partnership Airport Projects Reaching Financial Closure

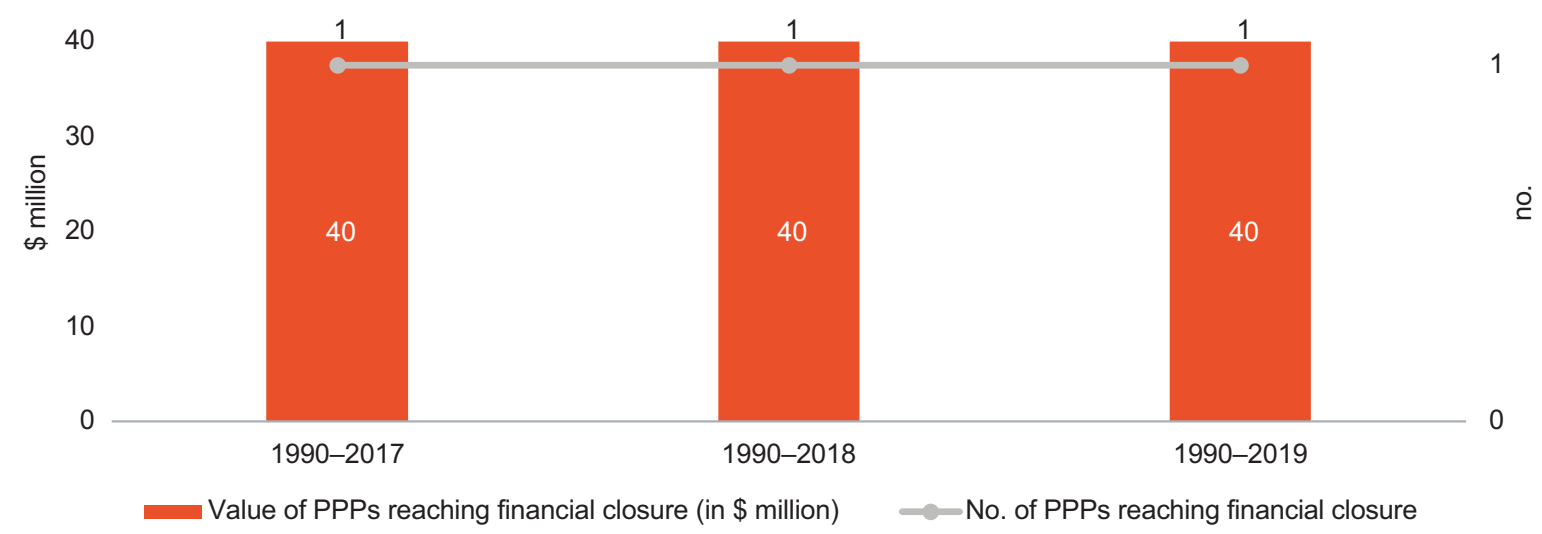

$\$=$ United States dollar, PPP = public-private partnership.

Note: Only active and concluded projects are considered in the above graph.

Source: World Bank. Infrastructure Finance, PPPs and Guarantees. Country Snapshots. Pakistan. https://ppi.worldbank.org/en/ snapshots/country/pakistan (accessed 1 September 2020). 
Figure 31 shows the number of PPP projects in Pakistan's airport sector that have received foreign sponsor participation.

\section{Figure 31: Public-Private Partnership Airport Projects with Foreign Sponsor Participation}

0

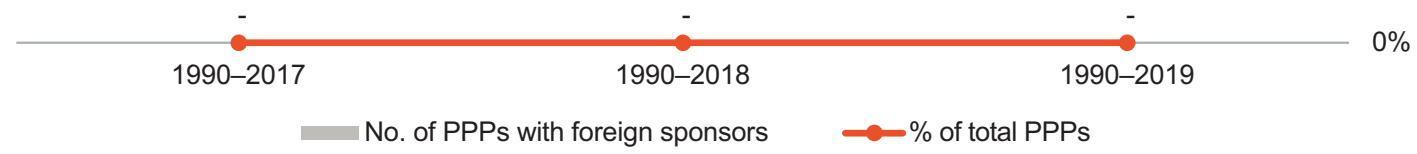

PPP = public-private partnership.

Note: Only active and concluded projects are considered in the above graph. The hyphen symbol (-) means there are no projects in the sector, or data are unavailable, or not applicable according to the database.

Source: World Bank. Infrastructure Finance, PPPs and Guarantees. Country Snapshots. Pakistan. https://ppi.worldbank.org/en/ snapshots/country/pakistan (accessed 1 September 2020).

Figure 32 shows the number of PPP projects in Pakistan's airport sector that have received government support, including viability gap funding (VGF) mechanism, government guarantees, and availability or performance payment.

Figure 32: Government Support to Public-Private Partnership Airport Projects

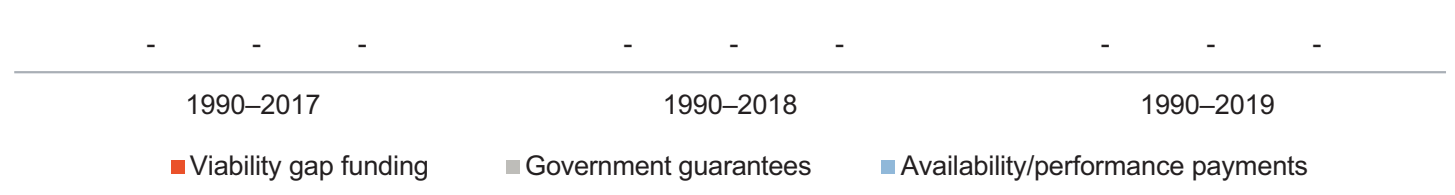

Note: Only active and concluded projects are considered in the above graph. The hyphen symbol (-) means there are no projects in the sector, or data are unavailable, or not applicable according to the database.

Source: World Bank. Infrastructure Finance, PPPs and Guarantees. Country Snapshots. Pakistan. https://ppi.worldbank.org/en/ snapshots/country/pakistan (accessed 1 September 2020).

Figure 33 presents the number of PPP projects in Pakistan's airport sector that have received payment in the form of user charges and government pay (off-take). 
Figure 33: Payment Mechanisms for Public-Private Partnership Airport Projects

\begin{tabular}{|c|c|c|}
\hline- & - & - \\
\hline 1990-2017 & 1990-2018 & 1990-2019 \\
\hline
\end{tabular}

Note: Only active and concluded projects are considered in the above graph. The hyphen symbol (-) means there are no projects in the sector, or data are unavailable, or not applicable according to the database.

Source: World Bank. Infrastructure Finance, PPPs and Guarantees. Country Snapshots. Pakistan. https://ppi.worldbank.org/en/ snapshots/country/pakistan (accessed 1 September 2020).

\subsection{Tariffs in the Airport Sector}

There is no information available regarding airport sector tariffs.

\subsection{Typical Risk Allocation for Public-Private Partnership Projects in the Airport Sector}

The PPP project structures in the airport sector is unavailable.

\subsection{Financing Details of Public-Private Partnership Projects in the Airport Sector}

Table 27 presents the financing details of PPP airport sector projects in Pakistan.

Table 27: Financing of Public-Private Partnership Projects in the Airport Sector

\begin{tabular}{|l|c|c|}
\hline Item & $1990-2017$ & $1990-2018$ \\
\hline PPP projects with foreign lending participation & $x$ & $\times \quad-2019$ \\
\hline $\begin{array}{l}\text { PPP projects that received export credit agency/international financing } \\
\text { institution support }\end{array}$ & $\times$ & $\times$ \\
\hline Typical debt-equity ratio & & $\ldots$ \\
\hline Time for financial closure & $\ldots$ \\
\hline Typical concession period & $\ldots$ \\
\hline Typical financial internal rate of return & $\ldots$ \\
\hline
\end{tabular}

$\ldots=$ data not available, $x=$ No, PPP $=$ public-private partnership.

Source: World Bank. Infrastructure Finance, PPPs and Guarantees. Country Snapshots. Pakistan. https://ppi.worldbank.org/en/ snapshots/country/pakistan (accessed 1 September 2020).

\section{Challenges in the Airport Sector}

The Pakistan Civil Aviation Authority (PCAA), a public entity, manages the aviation sector. Although the National Aviation Policy intends to introduce PPP models in the airport sector, the sector focus is on the use of public funding for the procurement of airport projects. While the Pakistan Civil Aviation Ordinance 1982 empowers the PCAA to award contracts for construction, maintenance, and operation of airports, it is unclear under the governing regime whether the PCAA has the mandate to issue license with respect to outsourcing of airport services (footnote 5). 


\section{E. ENERGY}

Consumption, share, access, imports, and investments in the energy sector are presented in Table 28.

Table 28: Status of Energy Projects

\begin{tabular}{|l|r|c|}
\hline Item & Value & Unit \\
\hline Electric power consumption & 471 & kW per capita \\
\hline Share of clean energy & 46.48 & $\%$ of total energy use \\
\hline Access to electricity & 71.1 & $\%$ of population \\
\hline Getting electricity (score out of 100) & 64 & no. \\
\hline Energy imports & 1,688 & $\%$ of total energy use \\
\hline Investment in energy with private participation & 134 & current \$ million \\
\hline $\begin{array}{l}\text { Total no. of projects with cumulative lending, grant, and technical assistance } \\
\text { commitments in the energy sector }\end{array}$ & 9,099 & no. \\
\hline $\begin{array}{l}\text { Total amount of cumulative lending, grant, and technical assistance } \\
\text { commitments in the energy sector }\end{array}$ & & \$ million \\
\hline
\end{tabular}

$\$=$ United States dollar, kWh = kilowatt-hour.

Sources: Asian Development Bank. Data Library. Cumulative Lending, Grant, and Technical Assistance Commitments. https://data.adb.org/ dataset/cumulative-lending-grant-and-technical-assistance-commitments (accessed 2 December 2020); The Economist Intelligence Unit. Infrascope 2018: Pakistan Country Profile. https://infrascope.eiu.com (accessed 2 December 2020); The Global Economy. Energy Imports_Country Rankings. https://www.theglobaleconomy.com/rankings/energy_imports/ (accessed 10 September 2020);

The Global Economy. Share of Clean Energy_Country Rankings. https://www.theglobaleconomy.com/rankings/share_of_clean_ energy/ (accessed 10 September 2020); World Bank. Data. Access to Electricity. https://data.worldbank.org/indicator/eg.elc.accs. zs? end=2018\&locations=mm-kh-uz-cn-bd-ge-in-id-kz-pk-ph-lk-th-vn\&start=2018\&view=bar (accessed 2 December 2020); World Bank. Doing Business. Ease of Doing Business Score-Getting Electricity. https://www.doingbusiness.org/en/data/doing-businessscore?topic=getting-electricity (accessed 2 December 2020).

\section{Contracting Agencies in the Energy Sector}

The Ministry of Water and Power is responsible for the overall administrative oversight relevant to the power sector. Established through the NEPRA Act, the National Electric Power Regulatory Authority (NEPRA) regulates the country's energy sector. NEPRA is mandated to regulate the provision of electric power services, including determination of electricity tariff, rates, charges, and other terms and conditions for supply of electric power services by the generation, transmission, and distribution companies (footnote 5).

Various agencies and companies are in charge of the distribution and transmission network and can contract with the private sector on behalf of the federal government. These include the Private Power and Infrastructure Board (PPIB), the Alternative Energy Development Board (AEDB), the National Transmission and Despatch Company (NTDC), the Punjab Power Development Board, and the Water and Power Development Authority (WAPDA) (footnote 5).

The PPIB was created in 1994 as a "one-window facilitator" on behalf of the Government of Pakistan to promote private investments in the power sector. In 2012, the PPIB was made a statutory organization through the Private Power and Infrastructure Board Act 2012 (Act VI of 2012). In November 2015, the PPIB Act was amended to expand the role of PPIB into facilitating public sector power and related infrastructure projects in independent power producer (IPP) mode. The PPIB approves IPPs, issues letters of intent and letters of support (including tripartite letters of support), approves feasibility studies, executes implementation agreements, and provides government guarantees. ${ }^{25}$

25 Government of Pakistan, Ministry of Energy (Power Division), Private Power and Infrastructure Board (PPIB). https://www.ppib.gov.pk/. 
The AEDB is the sole representing agency of the federal government. It was established in May 2003 mainly to facilitate, promote, and encourage development of renewable energy in Pakistan and to introduce alternative and renewable energy at an accelerated rate. The administrative control of the AEDB was transferred to the Ministry of Water and Power in 2006. The Government of Pakistan has, among other things, mandated the AEDB to

- implement policies, programs, and projects with the private sector in the field of alternative and renewable energy;

- assist and facilitate development and generation of alternative and renewable energy to achieve sustainable economic growth;

- encourage transfer of technology and develop indigenous manufacturing base for alternative and renewable energy technology;

- promote provision of energy services that are based on alternative and renewable energy resources; and

- undertake alternative and renewable energy projects on commercial scale (AEDB Act 2010). ${ }^{26}$

\section{Energy Sector Laws and Regulations}

NEPRA was established as an autonomous body to regulate tariffs in the energy sector. It is also tasked to issue relevant licenses (e.g., generation and transmission licenses) and to ensure the sustainability of the sector in the long term. The role of NEPRA constitutes the regulatory function required to ensure a competitive industry that has a reliable and adequate supply of electric power (footnote 25 ).

Even though the private partners under the energy market are permitted to sell directly to bulk-power consumers, energy is routed through the power purchaser to transmission and distribution companies, which then distribute energy to the end-consumers. Therefore, even though the private partners get payments for the energy off-taken from them, they may not sell directly to end-consumers. The minimum equity requirement for an IPP in Pakistan is $20 \%$ of the total project cost (footnote 26 ).

The government replaced the 2006 policy on Development of Renewable Energy for Power Generation with Alternative and Renewable Energy (ARE) Policy in 2019 to create a conducive environment for the sustainable growth of the ARE sector in Pakistan. The ARE Policy 2019 includes a variety of investment options for tapping different ARE resources for on-grid and off-grid applications as well as encouraging consumer-driven applications and initiatives.

Hydropower projects in the private sector are being implemented on build-own-operate-transfer (BOOT) basis. Based on this model, the project shall be transferred to the government at the end of the concession period. The term of concession period for the private sector is 30 years, after which the project will be transferred to the relevant provincial government (as the case may be) for PRs1 (footnote 25).

\subsection{Foreign Investment Restrictions in the Energy Sector}

The maximum equity investment allowed for foreign investors in greenfield projects is shown in Table 29.

26 Government of Pakistan, Ministry of Energy (Power Division), Alternative Energy Development Board (AEDB). E-Library. http://www.aedb.org/ ju-elibrary/ (accessed 1 September 2020). 
Table 29: Foreign Investment in the Energy Sector

\begin{tabular}{|l|c|c|c|}
\hline Business Activity & 2017 & 2018 & 2019 \\
\hline Power generation & $100 \%$ & $100 \%$ & $100 \%$ \\
\hline Power transmission & $100 \%$ & $100 \%$ & $100 \%$ \\
\hline Power distribution & $100 \%$ & $100 \%$ & $100 \%$ \\
\hline Oil and gas & $100 \%$ & $100 \%$ & $100 \%$ \\
\hline
\end{tabular}

Source: Asian Development Bank. 2019. Public-Private Partnership Monitor. Second Edition. Manila. https://www.adb.org/sites/default/ files/publication/509426/ppp-monitor-second-edition.pdf.

\subsection{Standard Contracts in the Energy Sector}

\begin{tabular}{|l|c|}
\hline Type of Contract & Availability \\
\hline Power purchase agreement & $\checkmark$ \\
\hline Capacity take-or-pay contract & $\checkmark$ \\
\hline Fuel supply agreement & $\checkmark$ \\
\hline Transmission and use of system agreement & $\checkmark$ \\
\hline Engineering, procurement, and construction contract & $\checkmark$ \\
\hline
\end{tabular}

$\checkmark=$ Yes

Source: Asian Development Bank. 2019. Public-Private Partnership Monitor. Second Edition. Manila. https://www.adb.org/sites/default/ files/publication/509426/ppp-monitor-second-edition.pdf.

The e-library section in the website of Alternative Energy Development Board provides standard documents for each of the alternative energy mode (footnote 26).

\section{Energy Sector Master Plan}

The planned overall future energy capacity in Pakistan across various segments is provided in Table 30.

\section{Table 30: Power Sector Planned Capacity in Pakistan}

(megawatt)

\begin{tabular}{|c|c|c|c|c|c|c|c|c|c|}
\hline \multirow[b]{2}{*}{ Year } & \multicolumn{2}{|c|}{$\begin{array}{c}\text { Thermal/ } \\
\text { Nonrenewable }\end{array}$} & \multicolumn{5}{|c|}{ Renewable } & \multirow[b]{2}{*}{$\begin{array}{l}\text { Nuclear } \\
\text { (Govt) }\end{array}$} & \multirow[b]{2}{*}{$\begin{array}{l}\text { Grand } \\
\text { Total }\end{array}$} \\
\hline & $\begin{array}{l}\text { IPPs } \\
\text { RLNG }\end{array}$ & IPPs Coal & $\begin{array}{l}\text { WAPDA/ } \\
\text { Hydro }\end{array}$ & IPPs & Wind & Solar & Bagasse & & \\
\hline 2019 & 0 & 0 & 0 & 0 & 0 & 524 & 790 & 0 & 1,314 \\
\hline 2020 & 800 & 0 & 128 & 102 & 265 & 0 & 0 & 0 & 1,295 \\
\hline $\begin{array}{l}2021 \text { and } \\
\text { beyond }\end{array}$ & 463 & 4,753 & 11,458 & 6,448 & 560 & 0 & 0 & 2,200 & 25,882 \\
\hline Grand Total & 1,263 & 4,753 & 11,586 & 6,550 & 825 & 524 & 790 & 2,200 & 28,491 \\
\hline
\end{tabular}

IPP = independent power producer, RLNG = regasified liquefied natural gas, WAPDA = Water and Power Development Authority. Source: Pakistan Credit Rating Agency Limited (PACRA). 2020. Power Sector Report on Power and Energy Generation. Islamabad. http://pacra.pk/research.

In 2019, the Renewable Energy Policy 2006 was revised into Policy for Alternative and Renewable Energy 2019 (ARE Policy 2019), which provides the roadmap for further realizing the ARE potential in Pakistan. Under the 
policy, Pakistan intends to have at least $20 \%$ of its generation capacity powered by ARE technologies by 2025 and $30 \%$ by 2030 . One of the objectives of the policy is to encourage private sector involvement in the ARE and "enable private sector investment and participation in on-grid and off-grid AREPs [projects for electricity generation using alternative and renewable energy technology] and innovative supply solution."27

A PPP pipeline of energy projects is available for various energy subsectors:

- A list of IPP projects is available on the Private Power and Infrastructure Board website. ${ }^{28}$

- A list of hydropower projects that are currently in the pipeline is available on the WAPDA website. ${ }^{29}$

- A list of renewable energy projects that are currently in the pipeline is available on the AEDB website. ${ }^{30}$ Currently, there are no projects listed on the site.

- A pipeline of IPP projects is available on the NTDC website. ${ }^{31}$

The list of projects from the PPIB is shown in Table 31.

Table 31: Pipeline of Public-Private Partnership Projects in the Energy Sector

\begin{tabular}{|c|c|c|c|c|c|c|}
\hline $\begin{array}{l}\text { Series } \\
\text { No. }\end{array}$ & Project & $\begin{array}{c}\text { Sponsor/ } \\
\text { Company Name }\end{array}$ & Location & Fuel & $\begin{array}{l}\text { Capacity } \\
\text { (MW) }\end{array}$ & $\begin{array}{c}\text { COD/ } \\
\text { Remarks Expected }\end{array}$ \\
\hline \multicolumn{7}{|l|}{2020} \\
\hline 1 & $\begin{array}{l}\text { 1,263-MW RLNG- } \\
\text { based project }\end{array}$ & PTPL & $\begin{array}{l}\text { Near Trimmu } \\
\text { Barrage, Jhang, } \\
\text { Punjab }\end{array}$ & RLNG & $\begin{array}{l}\text { GT1 and } \\
\text { GT2: } 800 \\
\text { ST: } 463\end{array}$ & $\begin{array}{l}\text { Open cycle by } \\
\text { December } 2020 \text {, } \\
\text { combined cycle by } \\
\text { June } 2021 \text {, under } \\
\text { construction }\end{array}$ \\
\hline \multicolumn{5}{|c|}{ Subtotal (2020) } & 1,263 & \\
\hline \multicolumn{7}{|l|}{2021} \\
\hline $2^{a}$ & $\begin{array}{l}\text { 330-MW Thar Coal- } \\
\text { based Power Project }\end{array}$ & Thar Energy Limited & Thar Block-II, Sindh & Coal & 330 & $\begin{array}{l}\text { March 2021, under } \\
\text { construction }\end{array}$ \\
\hline $3^{a}$ & $\begin{array}{l}\text { 330-MW Thar Coal- } \\
\text { based Power Project }\end{array}$ & $\begin{array}{l}\text { Thal Nova Power } \\
\text { Thar (Pvt) Ltd }\end{array}$ & Thar Block-II, Sindh & Coal & 330 & $\begin{array}{l}\text { March 2021, LOS } \\
\text { issued, FC in progress }\end{array}$ \\
\hline 4 & $\begin{array}{l}\text { 660-MW Thar Coal- } \\
\text { based Power Project }\end{array}$ & $\begin{array}{l}\text { Lucky Electric Power } \\
\text { Company Ltd. }\end{array}$ & Port Qasim, Karachi & Coal & 660 & $\begin{array}{l}\text { March 2021, under } \\
\text { construction }\end{array}$ \\
\hline 5 & $\begin{array}{l}\text { Riali-II Hydropower } \\
\text { Project }\end{array}$ & $\begin{array}{l}\text { Riali Hydro Power } \\
\text { Co. }\end{array}$ & $\begin{array}{l}\text { Ghori Wala Nullah, } \\
\text { Muzaffarabad AJ\&K }\end{array}$ & Hydel & 708 & $\begin{array}{l}\text { April 2021, LOS } \\
\text { issued, FC in progress }\end{array}$ \\
\hline $6^{a}$ & $\begin{array}{l}\text { Karot Hydropower } \\
\text { Project }\end{array}$ & $\begin{array}{l}\text { Karot Power Co. } \\
\text { Pvt Ltd }\end{array}$ & $\begin{array}{l}\text { Jehlum River, Dist. } \\
\text { Rawalpindi, Punjab }\end{array}$ & Hydel & 720 & $\begin{array}{l}\text { December } 2021 \text {, } \\
\text { under construction }\end{array}$ \\
\hline \multicolumn{5}{|c|}{ Subtotal (2021) } & 2,047 & \\
\hline
\end{tabular}

27 Government of Pakistan, Ministry of Energy (Power Division), AEDB. 2019. Power Policy: Alternative and Renewable Energy. Islamabad. http://www. aedb.org/images/ARE_Policy_2019_AEDB.pdf.

28 Government of Pakistan, PPIB. Upcoming IPPs (as of 4 December 2020). https://www.ppib.gov.pk/upcomming_ipps.html (accessed 15 December 2020).

29 Government of Pakistan, WAPDA. Hydro Power Projects-Future. http://www.wapda.gov.pk/index.php/duber-khwar-hydropower-menu-2/itemlist/ category/34-future (accessed 15 December 2020).

30 Government of Pakistan, Ministry of Energy (Power Division), AEDB. http://www.aedb.org/\#

31 Government of Pakistan, National Transmission and Despatch Company Limited. Future Projects. http://ntdc.gov.pk/casa (accessed 15 December 2020) 
Table 31 continued

\begin{tabular}{|c|c|c|c|c|c|c|}
\hline $\begin{array}{l}\text { Series } \\
\text { No. }\end{array}$ & Project & $\begin{array}{c}\text { Sponsor/ } \\
\text { Company Name }\end{array}$ & Location & Fuel & $\begin{array}{c}\text { Capacity } \\
\text { (MW) }\end{array}$ & $\begin{array}{c}\text { COD/ } \\
\text { Remarks Expected }\end{array}$ \\
\hline \multicolumn{7}{|l|}{2022} \\
\hline 7 & $\begin{array}{l}\text { 330-MW Thar } \\
\text { Coal-based Power } \\
\text { Project }\end{array}$ & $\begin{array}{l}\text { Siddiqsons Energy } \\
\text { Limited }\end{array}$ & Thar Block-II, Sindh & Coal & 330 & $\begin{array}{l}\text { March 2022, } \\
\text { LOS issued, FC in } \\
\text { progress }\end{array}$ \\
\hline $8(i)^{a}$ & $\begin{array}{l}\text { 1,320-MW Thar } \\
\text { Coal-based Power } \\
\text { Project }\end{array}$ & $\begin{array}{l}\text { Thar Coal Block-I } \\
\text { Power Generation } \\
\text { Co. Ltd. }\end{array}$ & Thar Block-I, Sindh & Coal & $\begin{array}{l}\text { first unit } \\
660\end{array}$ & $\begin{array}{l}\text { August } 2022, \\
\text { LOS issued, FC in } \\
\text { progress }\end{array}$ \\
\hline $9^{a}$ & $\begin{array}{l}\text { Suki Kinari } \\
\text { Hydropower Project }\end{array}$ & S.K Hydro Pvt Ltd & $\begin{array}{l}\text { Kunhar River, } \\
\text { Mansehra, KP }\end{array}$ & Hydel & 884 & $\begin{array}{l}\text { December } 2022 \text {, } \\
\text { under construction }\end{array}$ \\
\hline $10^{a}$ & $\begin{array}{l}\text { 300-MW Imported } \\
\text { Coal-based Power } \\
\text { Project }\end{array}$ & $\begin{array}{l}\text { China } \\
\text { Communication } \\
\text { Construction Co. }\end{array}$ & Gwadar, Balochistan & Coal & 300 & $\begin{array}{l}\text { Last quarter of } 2022, \\
\text { LOS issued, } \mathrm{FC} \text { in } \\
\text { progress }\end{array}$ \\
\hline \multicolumn{5}{|c|}{ Subtotal (2022) } & 2,174 & \\
\hline \multicolumn{7}{|l|}{2023} \\
\hline $8(\mathrm{ii})^{\mathrm{a}}$ & $\begin{array}{l}\text { 1,320-MW Thar } \\
\text { Coal-based Power } \\
\text { Project }\end{array}$ & $\begin{array}{l}\text { Thar Coal Block-I } \\
\text { Power Generation } \\
\text { Co. Ltd. }\end{array}$ & Thar Block-I, Sindh & Coal & $\begin{array}{l}\text { second } \\
\text { unit } \\
660\end{array}$ & $\begin{array}{l}\text { February } 2023, \\
\text { LOS issued, } F C \text { in } \\
\text { progress }\end{array}$ \\
\hline $11^{a}$ & $\begin{array}{l}\text { 1,320-MW Thar } \\
\text { Coal-based Power } \\
\text { Project }\end{array}$ & $\begin{array}{l}\text { Oracle Coal Fields } \\
\text { PLC England }\end{array}$ & Thar Block VI, Sindh & Coal & 1,320 & $\begin{array}{l}\text { June } 2023 \text {, issuance } \\
\text { of NTP and LOI in } \\
\text { process }\end{array}$ \\
\hline \multicolumn{5}{|c|}{ Subtotal (2023) } & 1,980 & \\
\hline \multicolumn{7}{|l|}{2024} \\
\hline 12 & $\begin{array}{l}\text { Kathai-II } \\
\text { Hydropower Project }\end{array}$ & $\begin{array}{l}\text { Kathai-II Hydro } \\
\text { (Pvt) Ltd. }\end{array}$ & $\begin{array}{l}\text { Kathai Nullah, } \\
\text { Hattian }\end{array}$ & Hydel & 8 & $\begin{array}{l}\text { April } 2024, \text { LOS } \\
\text { issued, FC in progress }\end{array}$ \\
\hline \multicolumn{5}{|c|}{ Subtotal (2024) } & 8 & \\
\hline \multicolumn{7}{|l|}{2026} \\
\hline $13^{a}$ & $\begin{array}{l}\text { Azad Pattan } \\
\text { Hydropower Project }\end{array}$ & $\begin{array}{l}\text { Azad Pattan Power } \\
\text { (Pvt) Ltd. }\end{array}$ & $\begin{array}{l}\text { Jehlum River, } \\
\text { Sudhnoti }\end{array}$ & Hydel & 700 & $\begin{array}{l}\text { June } 2026, \text { LOS } \\
\text { issued, FC in progress }\end{array}$ \\
\hline $14^{a}$ & $\begin{array}{l}\text { Kohala Hydropower } \\
\text { Project }\end{array}$ & $\begin{array}{l}\text { Kohala Hydro } \\
\text { Company Limited }\end{array}$ & $\begin{array}{l}\text { Jehlum River/ } \\
\text { Kohala }\end{array}$ & Hydel & 1,124 & $\begin{array}{l}\text { June } 2026, \text { LOS } \\
\text { issued, FC in } \\
\text { progress }\end{array}$ \\
\hline 15 & $\begin{array}{l}\text { Ashkot Hydropower } \\
\text { Project }\end{array}$ & $\begin{array}{l}\text { Ashkot Energy (Pvt) } \\
\text { Ltd. }\end{array}$ & Neelum River & Hydel & 300 & $\begin{array}{l}\text { December 2026; } \\
\text { Government of } \\
\text { AJ\&K transferred } \\
\text { the project to the } \\
\text { PPIB for further } \\
\text { processing (project } \\
\text { is under evaluation) }\end{array}$ \\
\hline \multicolumn{5}{|c|}{ Subtotal (2026) } & 2,124 & \\
\hline \multicolumn{7}{|l|}{2028} \\
\hline 16 & $\begin{array}{l}\text { Mahl Hydropower } \\
\text { Project }\end{array}$ & $\begin{array}{l}\text { CWE Investment } \\
\text { Corporation/China } \\
\text { Three Gorges and } \\
\text { Trans Tech Pakistan }\end{array}$ & $\begin{array}{l}\text { Jehlum River, } \\
\text { Punjab }\end{array}$ & Hydel & 640 & $\begin{array}{l}\text { June } 2028 \text {, LOI } \\
\text { issued, LOS in } \\
\text { progress, tariff } \\
\text { determined by } \\
\text { NEPRA }\end{array}$ \\
\hline
\end{tabular}


Table 31 continued

\begin{tabular}{|c|c|c|c|c|c|c|}
\hline $\begin{array}{l}\text { Series } \\
\text { No. }\end{array}$ & Project & $\begin{array}{c}\text { Sponsor/ } \\
\text { Company Name }\end{array}$ & Location & Fuel & $\begin{array}{l}\text { Capacity } \\
\text { (MW) }\end{array}$ & $\begin{array}{c}\text { COD/ } \\
\text { Remarks Expected }\end{array}$ \\
\hline 17 & $\begin{array}{l}\text { Athmuqam } \\
\text { Hydropower Project }\end{array}$ & $\begin{array}{l}\text { Korea Hydro and } \\
\text { Nuclear Company }\end{array}$ & Neelum River & Hydel & 450 & $\begin{array}{l}\text { December } 2028, \mathrm{LOI} \\
\text { issued, FS completed } \\
\text { and approved by the } \\
\text { POE, sponsors } \\
\text { initiated tariff } \\
\text { determination } \\
\text { process through the } \\
\text { CPPAG }\end{array}$ \\
\hline 18 & $\begin{array}{l}\text { Turtonas-Uzghor } \\
\text { Hydropower Project }\end{array}$ & $\begin{array}{l}\text { Sinohydro-Sachal } \\
\text { Consortium }\end{array}$ & $\begin{array}{l}\text { Golen Gol River, } \\
\text { Chitral Valley KP }\end{array}$ & Hydel & 82 & $\begin{array}{l}\text { December 2028, LOI } \\
\text { issued, FS completed } \\
\text { and approved by the } \\
\text { POE, tariff petition } \\
\text { is with NEPRA for } \\
\text { determination/ } \\
\text { approval }\end{array}$ \\
\hline \multicolumn{5}{|c|}{ Subtotal (2028) } & 1,172 & \\
\hline 19 & $\begin{array}{l}\text { Kaigah Hydropower } \\
\text { Project }\end{array}$ & $\ldots$ & $\begin{array}{l}\text { Kaigah, Indus River, } \\
\text { KP }\end{array}$ & Hydel & 548 & \multirow{4}{*}{$\begin{array}{l}\text { To be advertised, } \\
\text { COD will be } \\
\text { assessed after } \\
\text { issuance of LOI, } \\
\text { not likely to achieve } \\
\text { COD before } 2028\end{array}$} \\
\hline 20 & $\begin{array}{l}\text { Chakothi-Hațan } \\
\text { Hydropower Project }\end{array}$ & $\ldots$ & Muzaffarabad & Hydel & 500 & \\
\hline 21 & $\begin{array}{l}\text { Rajdhani } \\
\text { Hydropower Project }\end{array}$ & $\ldots$ & Poonch River & Hydel & 132 & \\
\hline 22 & $\begin{array}{l}\text { Neckeherdim-Paur } \\
\text { Hydropower Project }\end{array}$ & $\ldots$ & $\begin{array}{l}\text { Yarkun River, Chitral } \\
\text { Valley KP }\end{array}$ & Hydel & 80 & \\
\hline \multicolumn{5}{|r|}{ Subtotal } & 1,260 & \\
\hline \multicolumn{5}{|c|}{ Grand Total } & 12,028 & \\
\hline
\end{tabular}

$\ldots=$ data not available, $\mathrm{COD}=$ commercial operations date, $\mathrm{CPPAG}=$ Central Power Purchasing Agency (Guarantee) Limited,

FC = financial closure, FS = feasibility study, GT = gas turbine, $\mathrm{KP}=$ Khyber Pakhtunkhwa, $\mathrm{LOI}=$ letter of intent, $\mathrm{LOS}=$ letter of support, $\mathrm{MW}=$ megawatt, NEPRA = National Electric Power Regulatory Authority, NTP = notice to proceed, POE $=$ Panel of Experts,

PPIB = Private Power and Infrastructure Board, PTPL = Punjab Thermal Power (Pvt) Limited, RLNG = regasified liquefied natural gas, $\mathrm{ST}=$ steam turbine.

a This project is taken up as part of the China-Pakistan Economic Corridor initiative.

Source: Government of Pakistan, PPIB. Upcoming IPPs (as of 4 December 2020). https://www.ppib.gov.pk/upcomming_ipps.html (accessed 15 December 2020).

The list of projects from the WAPDA is shown in Table 32.

\section{Table 32: Pipeline of Public-Private Partnership Projects in the Energy Sector (Hydropower)}

\begin{tabular}{l|l|l|}
$\begin{array}{l}\text { Series } \\
\text { No. }\end{array}$ & \multicolumn{1}{|c}{ Project Name } & \multicolumn{1}{c|}{ Brief Status } \\
\hline $\mathbf{1}$ & Akhori Dam Project & $\begin{array}{l}\text { Power generation capacity of } 600 \mathrm{MW} \text {; feasibility study prepared in 2016; } \\
\text { Ministry discussions on way forward. }\end{array}$ \\
\hline $\mathbf{2}$ & Basho Hydropower Project & $\begin{array}{l}\text { Power generation capacity of 40 MW; updating of feasibility study completed in } \\
2011 \text { with AFD grant assistance; planned to be taken up on donor funding }\end{array}$ \\
\hline $\mathbf{3}$ & Chitral Power Enhancement & $\begin{array}{l}\text { Capacity enhancement from 1 MW to } 5 \mathrm{MW} \text {; planned to be taken up on donor } \\
\text { funding }\end{array}$ \\
\hline
\end{tabular}


Table 32 continued

\begin{tabular}{|c|c|c|}
\hline $\begin{array}{l}\text { Series } \\
\text { No. }\end{array}$ & Project Name & Brief Status \\
\hline 4 & $\begin{array}{l}\text { Dudhnial Dam Multipurpose } \\
\text { Project }\end{array}$ & $\begin{array}{l}\text { Power generation capacity of } 960 \text { MW; submitted to Planning Commission by } \\
\text { the MOWR in April 2019; awaiting approval }\end{array}$ \\
\hline 5 & Hingol Dam Project & $\begin{array}{l}\text { Power generation capacity of } 1.37 \mathrm{MW} \text {; FFC, MOWR cleared the PC-II and } \\
\text { submitted for approval of Departmental Development Working Party in } \\
\text { January } 2020\end{array}$ \\
\hline 6 & Lower Palas Valley & $\begin{array}{l}\text { Power generation capacity of } 665 \mathrm{MW} \text {; discussions between the MOWR, } \\
\text { WAPDA, and the provincial government of Pakhtunkhwa ongoing for finalizing } \\
\text { the project development }\end{array}$ \\
\hline 7 & Lower Spat Gah & $\begin{array}{l}\text { Power generation capacity of } 496 \mathrm{MW} \text {; WAPDA intends to develop the project } \\
\text { under conventional mode through donor financing; discussions between } \\
\text { WAPDA and the provincial government of Pakhtunkhwa ongoing for finalizing } \\
\text { the project procurement }\end{array}$ \\
\hline 8 & $\begin{array}{l}\text { Middle Palas Valley } \\
\text { Hydropower Project }\end{array}$ & Power generation capacity of 398 MW; pre-feasibility study completed in 2008 \\
\hline 9 & $\begin{array}{l}\text { Middle Spat Gah Hydropower } \\
\text { Project }\end{array}$ & Power generation capacity of 489 MW; pre-feasibility study completed in 2008 \\
\hline 10 & Murunj Dam Project & $\begin{array}{l}\text { Power generation capacity of } 12 \mathrm{MW} \text {; hiring of consultancy services for } \\
\text { undertaking necessary technical studies under progress }\end{array}$ \\
\hline 11 & Patan & $\begin{array}{l}\text { Power generation capacity of 2,400 MW; PC-II for detailed engineering design, } \\
\text { preparation of tender document, and PC-I in process with the MOWR since } \\
\text { February 2019; ADB has shown interest in project appraisal and financing }\end{array}$ \\
\hline 12 & Phandar Hydropower Project & $\begin{array}{l}\text { Power generation capacity of } 80 \mathrm{MW} \text {; detailed engineering design and } \\
\text { preparation of tender document completed in 2013; project would be taken } \\
\text { up after arrangement of financing from donor agencies and the relevant local } \\
\text { government; to be implemented by WAPDA }\end{array}$ \\
\hline 13 & Renala Power Rehabilitation & $\begin{array}{l}\text { Power generation capacity of } 4.4 \mathrm{MW} \text {; feasibility study completed by WAPDA } \\
\text { Hydro-planning Department in 2013; AFD France has shown interest to finance } \\
\text { the project; finalization pending }\end{array}$ \\
\hline 14 & $\begin{array}{l}\text { Shyok Dam Multipurpose } \\
\text { Project }\end{array}$ & $\begin{array}{l}\text { Power generation capacity of } 640 \mathrm{MW} \text {; draft feasibility study expected to be } \\
\text { completed by April } 2020\end{array}$ \\
\hline 15 & Tank Zam Dam Project & $\begin{array}{l}\text { Power generation capacity of } 25.4 \mathrm{MW} \text {; updated PC-II for detailed } \\
\text { engineering design and tender documents; preparation of PC-I amounting } \\
\text { to PRs } 212.576 \text { million submitted to the MOWR on } 22 \text { March 2018; planned to } \\
\text { be taken up under the PSDP }\end{array}$ \\
\hline 16 & Thakot Hydropower Project & Power generation capacity of 4,927 MW; feasibility study in progress \\
\hline 17 & Tungas Hydropower Project & $\begin{array}{l}\text { Power generation capacity of } 2,200 \mathrm{MW} \text {; updating of feasibility study in } \\
\text { progress }\end{array}$ \\
\hline 18 & $\begin{array}{l}\text { Upper Palas Valley Hydropower } \\
\text { Project }\end{array}$ & Power generation capacity of 157 MW; pre-feasibility study completed in 2008 \\
\hline 19 & $\begin{array}{l}\text { Upper Spat Gah Hydropower } \\
\text { Project }\end{array}$ & Power generation capacity of $252 \mathrm{MW}$; pre-feasibility study completed in 2008 \\
\hline 20 & Yulbo Hydropower Project & Power generation capacity of 2,800 MW; technical studies being finalized \\
\hline
\end{tabular}

$\mathrm{ADB}=$ Asian Development Bank, AFD = French Development Agency (Agence Française de Développement), FFC = Fauji Fertilizer Company Limited, $\mathrm{MW}=$ megawatt, $\mathrm{MOWR}=$ Ministry of Water Resources, $\mathrm{PC}=$ project component, $\mathrm{PRs}=\mathrm{Pakistan}$ rupees, $\mathrm{PSDP}=$ public sector development program, WAPDA = Water and Power Development Authority.

Source: Government of Pakistan, WAPDA. Hydro Power Projects-Future. http://www.wapda.gov.pk/index.php/duber-khwarhydropower-menu-2/itemlist/category/34-future (accessed 15 December 2020). 


\section{Projects under Preparation and Procurement in the Energy Sector}

While the list of projects, as shown in Table 54, indicates the total target of the sector in terms of developing power projects, the exact current status in terms of preparation and procurement could not be accessed. Figure 34 indicates the number of projects under preparation and procurement in Pakistan's energy sector.

Figure 34: Public-Private Partnership Energy Projects under Preparation and Procurement

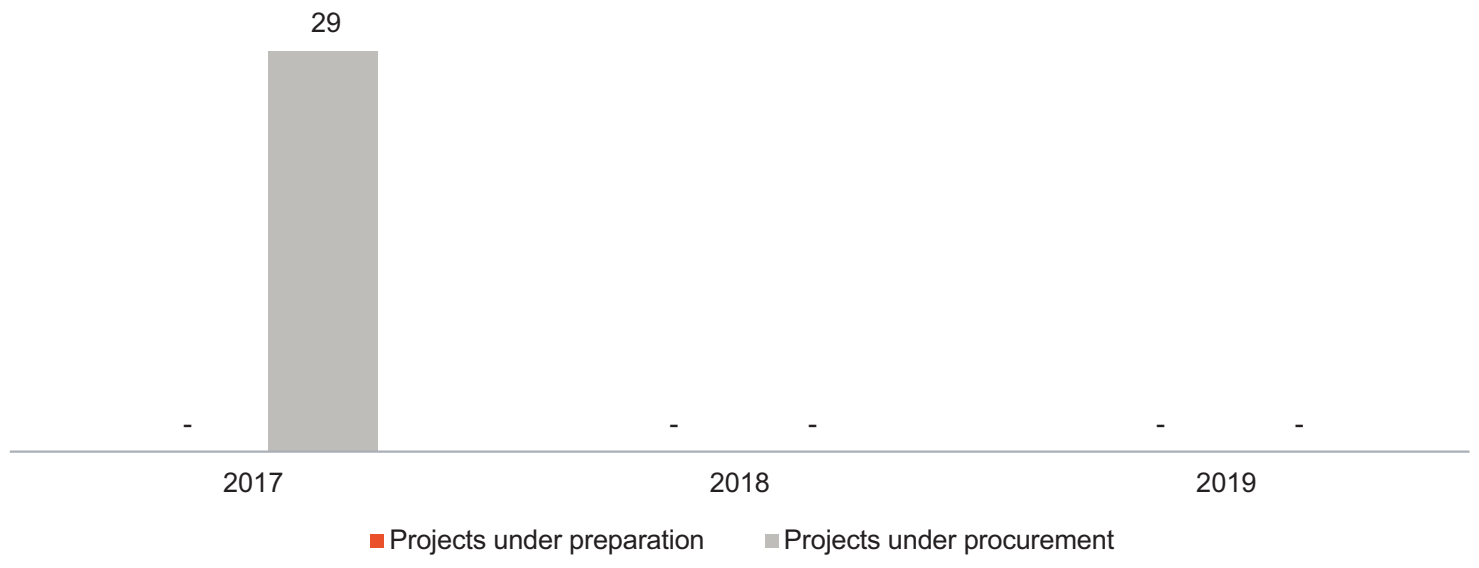

Note: The hyphen symbol (-) means there are no projects in the sector, or data are unavailable.

Source: Asian Development Bank. 2019. Public-Private Partnership Monitor. Second Edition. Manila. https://www.adb.org/sites/ default/files/publication/509426/ppp-monitor-second-edition.pdf.

\section{Features of Past Public-Private Partnership Projects in the Energy Sector}

Figure 35 shows the number of PPP projects in Pakistan's energy sector, procured through various modes, including direct appointment, unsolicited bids, and competitive bids.

Figure 35: Modes of Procurement for Public-Private Partnership Energy Projects

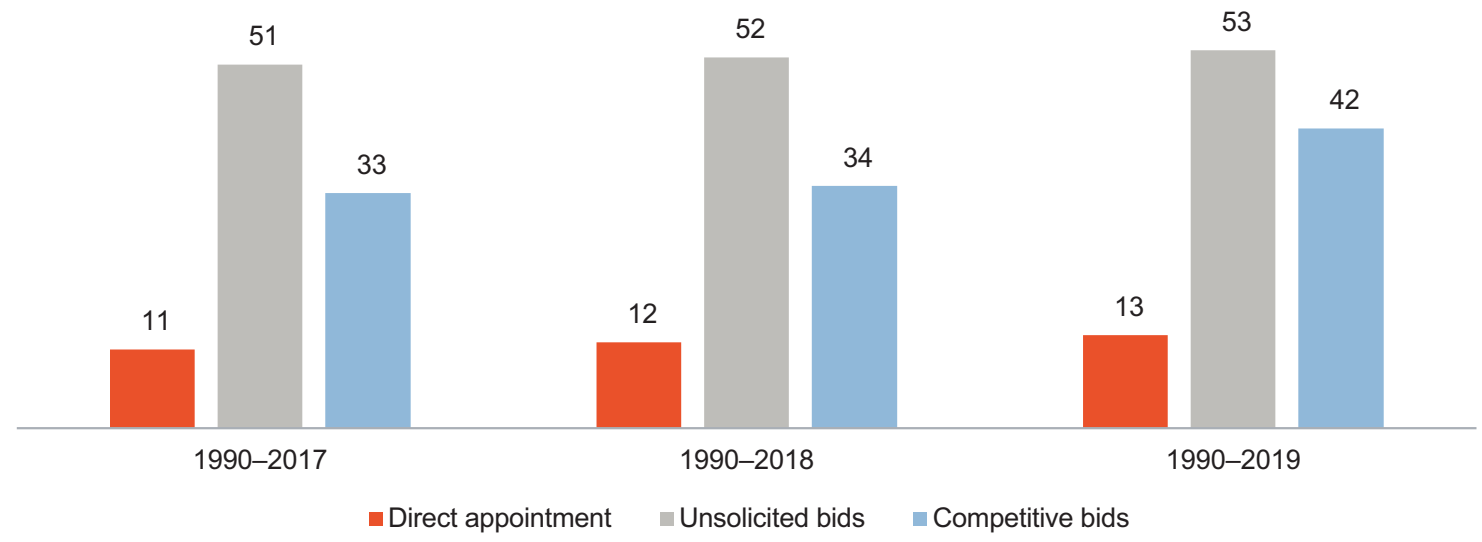

Note: Only active and concluded projects are considered in the above graph. Information on four projects could not be assessed.

Source: World Bank. Infrastructure Finance, PPPs and Guarantees. Country Snapshots. Pakistan. https://ppi.worldbank.org/en/ snapshots/country/pakistan (accessed 1 September 2020). 
Figure 36 shows the number of PPP projects in Pakistan's energy sector that have reached financial closure, and the total value of those projects.

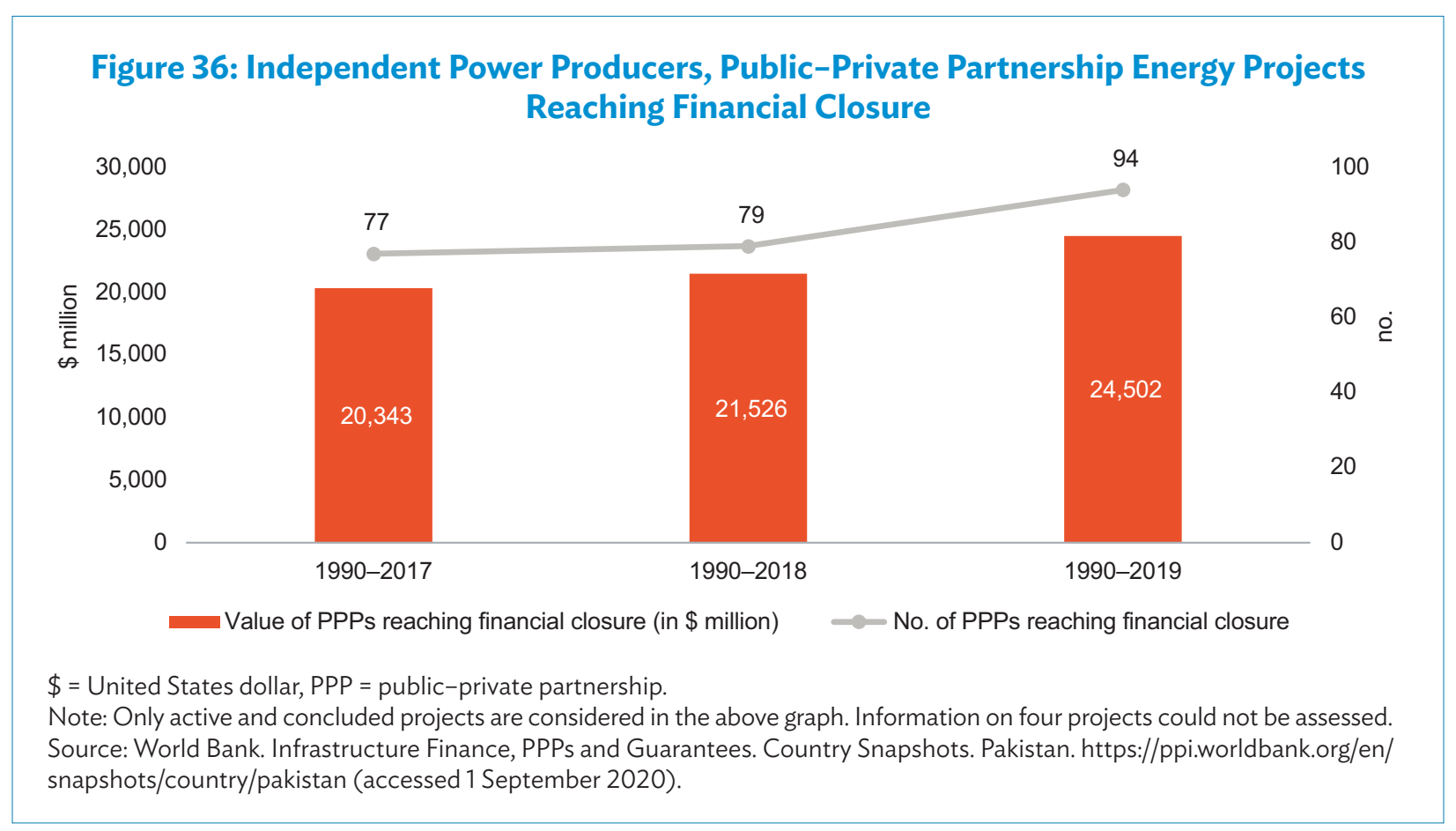

Figure 37 presents the number of PPP projects that have received foreign sponsor participation in Pakistan's energy sector.

Figure 37: Independent Power Producers, Public-Private Partnership Energy Projects with Foreign Sponsor Participation

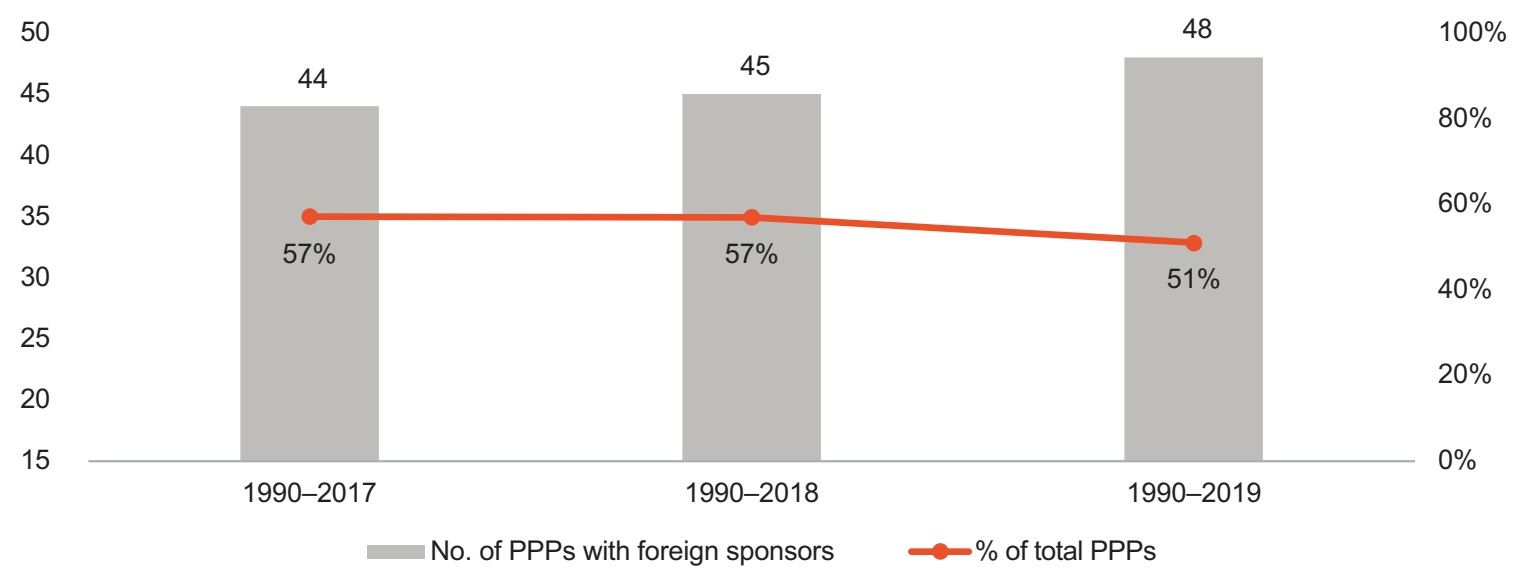

PPP = public-private partnership.

Note: Only active and concluded projects are considered in the above graph. Information on four projects could not be assessed. Source: World Bank. Infrastructure Finance, PPPs and Guarantees. Country Snapshots. Pakistan. https://ppi.worldbank.org/en/ snapshots/country/pakistan (accessed 1 September 2020). 
Figure 38 shows the number of PPP projects in Pakistan's energy sector that have received government support, including the VGF mechanism, government guarantees, and availability or performance payment.

Figure 38: Government Support to Independent Power Producers and Public-Private Partnership Energy Projects

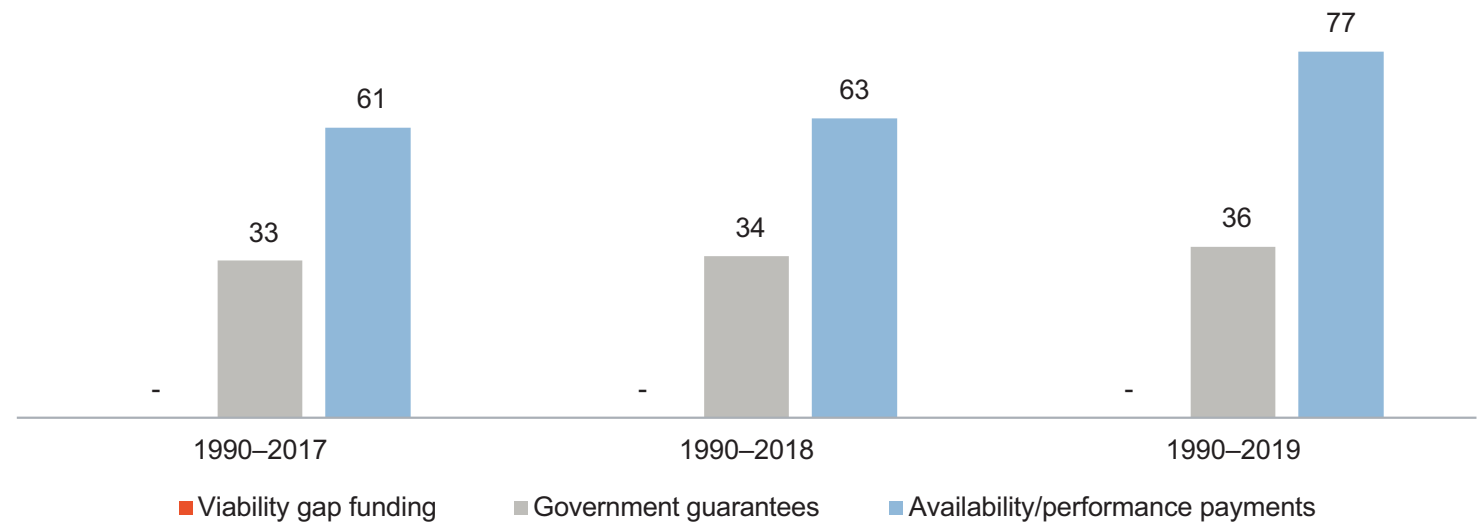

Note: Only active and concluded projects are considered in the above graph. The hyphen symbol (-) means there are no projects in the sector, or data are unavailable, or not applicable according to the database.

Source: World Bank. Infrastructure Finance, PPPs and Guarantees. Country Snapshots. Pakistan. https://ppi.worldbank.org/en/ snapshots/country/pakistan (accessed 1 September 2020).

Figure 39 presents the number of PPP projects in Pakistan's energy sector that have received payment in the form of user charges and government pay (off-take).

Figure 39: Payment Mechanisms for Public-Private Partnership Energy Projects

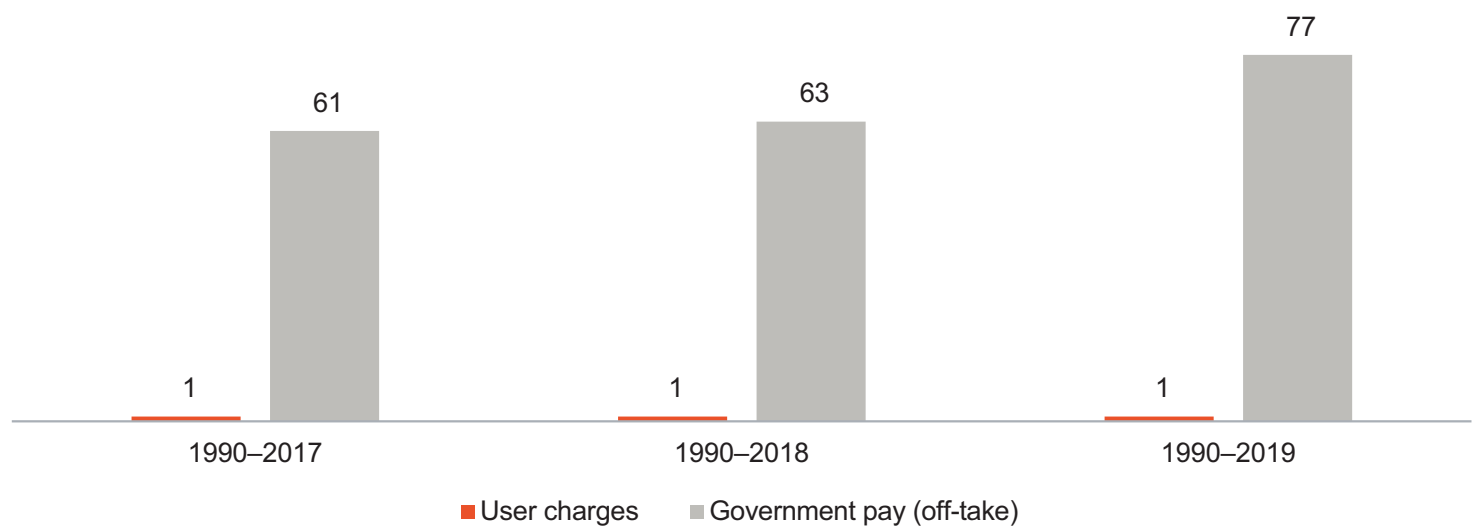

Note: Only active and concluded projects are considered in the above graph. 'User charges' category include wholesale and sale toward power purchase agreements or transmission fees to private entities.

Source: World Bank. Infrastructure Finance, PPPs and Guarantees. Country Snapshots. Pakistan. https://ppi.worldbank.org/en/ snapshots/country/pakistan (accessed 1 September 2020).

\subsection{Tariffs in the Energy Sector}

To promote fair competition in the electricity industry and to protect the interests of consumers, producers, and sellers of electric power, the Government of Pakistan enacted the Regulation of Generation, Transmission 
and Distribution of Electric Power Act 1997. Under this Act, the NEPRA was created to introduce transparent and judicious economic regulation, based on sound commercial principles, to the power sector of Pakistan. One of the primary responsibilities of NEPRA is to determine the tariff for the various generation, transmission, and distribution companies, including the IPPs. NEPRA follows a standard and transparent procedure for tariff determination, which includes public hearing and views from all stakeholders. ${ }^{32}$

NEPRA is responsible for setting the tariffs paid for electricity by customers. The PPP model in the power generation sector typically follows an IPP framework where IPPs enter into a power purchase agreement (PPA) with a state-owned off-taker. The tariffs are regulated by NEPRA to provide a suitable rate of return for private investors. In some cases, there are other power projects that are procured as build-operate-transfer (BOT) projects. The majority of the PPP projects consist of IPPs receiving tariffs through a long-term PPA (footnote 5).

To facilitate the development of these technologies, NEPRA has issued upfront tariffs for generation from the respective technologies. Since solar projects have been proposed to be developed through a competitive bidding process, NEPRA does not issue tariff rates for the technology (footnote 32).

Examples of current tariffs in Pakistan set by the NEPRA for selected IPPs are shown in Table 33.

\section{Table 33: Tariffs Set by the National Electric Power Regulatory Authority for Energy Projects in Pakistan}

\begin{tabular}{|l|c|}
\hline \multicolumn{1}{|l|}{ Type } & PRs/kWh (Levelized Tariff) \\
\hline Thermal & 4.8675 \\
\hline Hydel & 11.3045 \\
\hline Wind & 7.5233 \\
\hline Solar & 12.1093 \\
\hline Bagasse or bioenergy & 10.4078 \\
\hline Waste-to-energy & 10.3170 \\
\hline
\end{tabular}

$\mathrm{kWh}=$ kilowatt-hour, PRs = Pakistan rupees.

Sources: Government of Pakistan, National Electric Power Regulatory Authority (NEPRA). 2009. Tariff Determination for a Sample Thermal Electric Power IPP Project. AES Pakistan (Pvt.) Ltd. https://nepra.org.pk/tariff/Tariff/IPPs/AES\%20PakGen/TRF-134\%20 AES\%20-\%202009\%20Determination.PDF; Government of Pakistan, NEPRA. 2013. Tariff Determination for a Sample Hydel Power Plant IPP Project. Blue Star Energy (Pvt.) Ltd. https://nepra.org.pk/tariff/Tariff/IPPs/Blue\%20Star\%20Energy/2013/TRF-201\%20 BSEL\%20Determination\%20Dt.02-01-2013\%2044-46.PDF; Government of Pakistan, NEPRA. 2020. Tariff Determination for a Sample Wind Power IPP Project. Act 2 Wind Power (Pvt.) Ltd. https://nepra.org.pk/tariff/Tariff/IPPs/000\%20IPPs\%20Wind/Act\%202\%20 Wind\%20Pvt\%20Limited/2020/TRF-489\%20AWPL\%20Modification\%2023-07-2020\%2018810-12.PDF; Government of Pakistan, NEPRA. 2016. Tariff Determination for a Sample Solar IPP Project. AJ Power (Private) Limited (AJPPL). https://nepra.org.pk/tariff/Tariff/ IPPs/002\%20Solar\%20IPPs/AJPPL/Revised\%20Decision\%20of\%20AJ\%20Power\%20Upfront\%20Tariff\%20Solar.PDF; Government of Pakistan, NEPRA. 2017. Tariff Determination for a Sample Bagasse-based Co-generation Power IPP Project. Alliance Power (Pvt.) Ltd. https://nepra.org.pk/tariff/Tariff/IPPs/05\%20Bioenergy/Alliance\%20Sugar\%20Mills/TRF-393\%20APPL\%20Upfront\%20Bagasse\%20 11-09-2017\%2015256-58.PDF; and Government of Pakistan, NEPRA. 2018. Tariff Determination for a Sample Waste-to-Energy IPP Project. Lahore Xingzhong Renewable Energy Company (Pvt.) Ltd. https://nepra.org.pk/tariff/Tariff/IPPs/05\%20Bioenergy/Lahore\%20 Xingzhong\%20Renewable\%20Energy\%20Company/TRF-445\%20LXREC\%20\%2020-07-2018\%2011883-85.PDF.

\subsection{Typical Risk Allocation for Public-Private Partnership Projects in the Energy Sector}

Information on typical risk allocation for the power sector is unavailable. 


\subsection{Financing Details for Public-Private Partnership Projects in the Energy Sector}

Table 34 presents the financing details of PPP energy sector projects in Pakistan.

Table 34: Financing of Public-Private Partnership Projects in the Energy Sector

\begin{tabular}{|c|c|c|c|}
\hline Item & 1990-2017 & 1990-2018 & 1990-2019 \\
\hline PPP projects with foreign lending participation (no.) & 37 & 39 & 54 \\
\hline $\begin{array}{l}\text { PPP projects that received export credit agency/international financing } \\
\text { institution support (no.) })^{a}\end{array}$ & 40 & 41 & 56 \\
\hline Typical debt-equity ratio & \multicolumn{3}{|c|}{$(75-80):(25-20)$} \\
\hline Time for financial closure & \multicolumn{3}{|c|}{$\ldots$} \\
\hline Typical concession period & \multicolumn{3}{|c|}{25 years } \\
\hline Typical financial internal rate of return & \multicolumn{3}{|c|}{$\ldots$} \\
\hline
\end{tabular}

... = data not available, $\mathrm{PPP}=$ public-private partnership.

Note: Only active and concluded projects are considered in the above table.

a Includes both foreign bank lending and international financial institution support.

Source: World Bank. Infrastructure Finance, PPPs and Guarantees. Country Snapshots. Pakistan. https://ppi.worldbank.org/en/ snapshots/country/pakistan (accessed 1 September 2020).

\section{Challenges in the Energy Sector}

Gap between end users and cost-recovery tariffs have caused payment arrears to IPPs and private sector players. Concerns about electricity payments discourage private sector participation (footnote 5 ).

There are constraints on the capacity of the transmission system. The transmission infrastructure cannot cope with large-scale investment in electricity generation, as is the case with rolling out public and private sector energy generation projects (footnote 5 ).

\section{F. WATER AND WASTEWATER}

Improved access to and investments in water and wastewater projects in Pakistan are presented in Table 35.

Table 35: Status of Water and Wastewater Projects

\begin{tabular}{|l|c|c|}
\hline Item & Value & Unit \\
\hline Improved water source access & 89 & \% of population with access \\
\hline Improved sanitation facilities access & 72 & $\%$ of population with access \\
\hline Investment in water and sanitation with private participation & $\ldots$ & current \$ million \\
\hline $\begin{array}{l}\text { Total no. of projects with cumulative lending, grant, and technical assistance } \\
\text { commitments in water and other urban infrastructure and services }\end{array}$ & 52 & no. \\
\hline $\begin{array}{l}\text { Total amount of cumulative lending, grant, and technical assistance } \\
\text { commitments in water and other urban infrastructure and services }\end{array}$ & 1,051 & \$ million \\
\hline
\end{tabular}

$\ldots=$ data not available, $\$$ = United States dollar.

Sources: Asian Development Bank (ADB). 2015. Country Partnership Strategy: Pakistan, 2015-2019. Manila. https://www.adb.org/ sites/default/files/institutional-document/171824/cps-pak-2015-2019.pdf; ADB. Data Library. Cumulative Lending, Grant, and Technical Assistance Commitments. https:/data.adb.org/dataset/cumulative-lending-grant-and-technical-assistance-commitments (accessed 2 December 2020); and The Economist Intelligence Unit. Infrascope 2018: Pakistan Country Profile. https://infrascope.eiu. com (accessed 2 December 2020). 


\section{Contracting Agencies in the Water and Wastewater Sector}

Bulk water. Pakistan's Water and Power Development Authority (WAPDA) was established through an Act of Parliament in 1958. It is an autonomous and statutory body under the administrative control of the federal government. WAPDA is responsible for the development of hydroelectric (or hydel) power and water sector projects. The Water Wing of WAPDA is responsible for planning, designing, and executing the water resources development projects in the sector of irrigation, drainage, and hydropower. Interprovincial major surface water projects, including large dams, are also operated and maintained by the Water Wing. ${ }^{33}$

Drinking water. Drinking water and sanitation policy is the constitutional responsibility of provincial governments. The federal government is only involved in policy development and the setting of guidelines, mostly through the Ministry of Climate Change (formerly Ministry of Environment). A National Drinking Water and Sanitation Committee was established in 2009 to implement both the National Sanitation Policy 2006 and the National Drinking Water Policy 2009. ${ }^{34}$ The overall goal of the National Drinking Water Policy is to improve the quality of life by reducing the incidence of death and illness caused by water-borne diseases through adequate provision of safe drinking water to the entire population at an affordable cost and in an equitable, efficient, and sustainable manner. It highlights the constitution responsibility of provincial and local governments (towns and tehsil municipal administrations (TMAs) to provide drinking water. ${ }^{35}$

\section{Water and Wastewater Sector Laws and Regulations}

The Water and Power Development Authority Act 1958 is the key regulation for the sector.

National Sanitation Policy 2006. The National Sanitation Policy, approved by the federal government in 2006, promotes the grassroots concept of community-led total sanitation in communities with less than 1,000 inhabitants. In larger communities, the National Sanitation Policy promotes a "component sharing model," under which, sewage and wastewater treatment facilities are provided by the communities in cases wherein the local government-developed disposal is not available (footnote 35).

National Drinking Water Policy 2009. In September 2009, the government approved the National Drinking Water Policy. It aims to provide safe drinking water at an affordable cost by 2025 to the entire population in Pakistan, including the poor and vulnerable. The Local Government Ordinance of 2001 highlights the responsibility of local governments to provide drinking water. The policy is expected to be reviewed and updated every 5 years to examine its implementation and efficacy and to adapt it to the changing situation in the country (footnote 35).

\begin{tabular}{|l|c|}
\hline Parameter & UA \\
\hline Can the private sector be given water abstraction rights? & UA \\
\hline Are there regulations in place on raw water extraction? & UA \\
\hline Are there regulations in place on the release of treated effluents?
\end{tabular}

$\checkmark=$ Yes, $x=$ No, NA = Not Applicable, UA = Unavailable.

Source: Asian Development Bank.

34 United Nations General Assembly. 2012. National Report Submitted in Accordance with Paragraph 5 of the Annex to Human Rights Council Resolution 16/21: Pakistan. https://www.upr-info.org/sites/default/files/document/pakistan/session_14_-_october_2012/ahrcwg.614pak1e.pdf.

35 Pakistan Water Supply and Sanitation Sector Vol II, https://hudphed.punjab.gov.pk/system/files/8\%28b\%29-Pakistan\%20Rural-Vol\%20II_v3\%20 12-6-13\%20print.pdf. 


\subsection{Foreign Investment Restrictions in the Water and Wastewater Sector}

The maximum allowed foreign ownership of equity in greenfield projects is shown in Table 36.

Table 36: Foreign Investment in the Water and Wastewater Sector

\begin{tabular}{|l|c|c|c|}
\hline Item & $\mathbf{2 0 1 7}$ & $\mathbf{2 0 1 8}$ & $\mathbf{2 0 1 9}$ \\
\hline Bulk water supply and treatment & $100 \%$ & $100 \%$ & $100 \%$ \\
\hline Water distribution & $100 \%$ & $100 \%$ & $100 \%$ \\
\hline Wastewater treatment & $100 \%$ & $100 \%$ & $100 \%$ \\
\hline Wastewater collection & $100 \%$ & $100 \%$ & $100 \%$ \\
\hline
\end{tabular}

Source: Asian Development Bank. 2019. Public-Private Partnership Monitor. Second Edition. Manila. https:/www.adb.org/sites/default/ files/publication/509426/ppp-monitor-second-edition.pdf.

\subsection{Standard Contracts in the Water and Wastewater Sector}

\begin{tabular}{|l|c|}
\hline Type of Contract & Availability \\
\hline Public-private partnership/concession agreement & UA \\
\hline Bulk water supply agreement & UA \\
\hline Performance-based operation and maintenance contract & UA \\
\hline Engineering, procurement, and construction contract & UA \\
\hline
\end{tabular}

$\mathrm{UA}=$ Unavailable.

Source: Asian Development Bank. 2019. Public-Private Partnership Monitor. Second Edition. Manila. https://www.adb.org/sites/default/ files/publication/509426/ppp-monitor-second-edition.pdf.

\section{Water and Wastewater Sector Master Plan}

The government approved the National Water Policy in 2018, which "lays down a broad policy framework and a set of principles for water security, on the basis of which the provincial governments can formulate their respective master plans and projects for water conservation, water development, and water management." ${ }^{36}$ The policy identifies 33 objectives, some of which are as follows:

- Augmentation of the available water resources of the country through judicious and equitable utilization via reservoirs, conservation, and efficient use;

- Improving urban water management by increasing system efficiency and reducing nonrevenue water through adequate investments to address drinking water demand, sewage disposal, and handling of wastewater and industrial effluents;

- Treatment and possible reuse of wastewater for domestic, agricultural, and industrial purposes;

- Encouraging beneficiary participation and PPPs; and

- Enhancing water productivity through infrastructure development and adoption of improved technologies in a sustainable manner.

36 Government of Pakistan, Ministry of Water Resources. 2018. National Water Policy 2018. Islamabad. http://mowr.gov.pk/wp-content/ uploads/2018/06/National-Water-policy-2018-2.pdf. 
The policy further states that "sectors that can benefit from PPP modalities and private sector participation (like urban water and sewage for example) should immediately be opened up for investment through appropriate policies. The introduction of private capital and discipline in project execution will not only introduce cost savings and efficiency during implementation but will also save time and create a competitive environment" (footnote 36).

\section{Projects under Preparation and Procurement in the Water and Wastewater Sector}

The list of projects in the water sector is unavailable.

Figure 40 presents the number of PPP projects that are under preparation and procurement in Pakistan's water and wastewater sector.

\section{Figure 40: Public-Private Partnership Water and Wastewater Projects under Preparation and Procurement}

\begin{tabular}{|c|c|c|c|c|}
\hline- & - & - & - & - \\
\hline \multicolumn{2}{|c|}{2017} & & & \\
\hline
\end{tabular}

Note: The hyphen symbol (-) means there are no projects in the sector, or data are unavailable.

Source: Asian Development Bank. 2019. Public-Private Partnership Monitor. Second Edition. Manila. https://www.adb.org/sites/ default/files/publication/509426/ppp-monitor-second-edition.pdf.

\section{Features of Past Public-Private Partnership Projects in the Water and Wastewater Sector}

The water and wastewater sector had no PPP projects in the past as per the World Bank Private Participation in Infrastructure (PPI) database.

Figure 41 shows the number of PPP projects in Pakistan's water and wastewater sector, procured through various modes, including direct appointment, unsolicited bids, and competitive bids. 


\section{Figure 41: Modes of Procurement for Public-Private Partnership Water and Wastewater Projects}

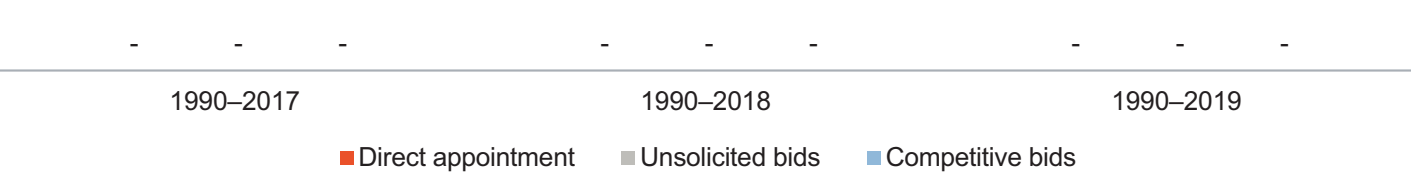

Note: Only active and concluded projects are considered in the above graph. The hyphen symbol (-) means there are no projects in the sector, or data are unavailable, or not applicable according to the database.

Source: World Bank. Infrastructure Finance, PPPs and Guarantees. Country Snapshots. Pakistan. https://ppi.worldbank.org/en/ snapshots/country/pakistan (accessed 1 September 2020).

Figure 42 presents the number of PPP projects in Pakistan's water and wastewater sector that have reached financial closure, and the total value of those projects.

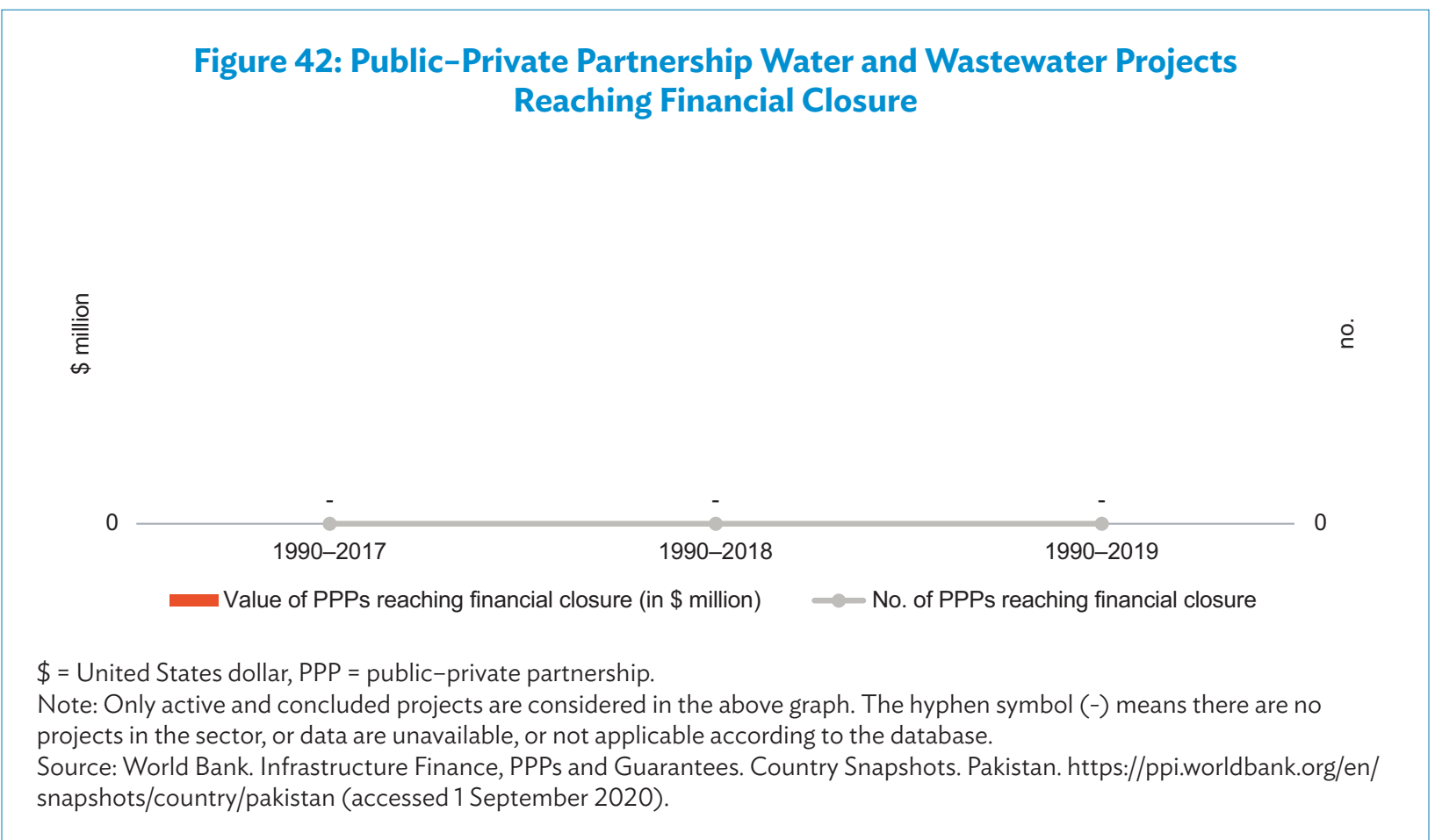


Figure 43 shows the number of PPP projects that have received foreign sponsor participation in Pakistan's water and wastewater sector.

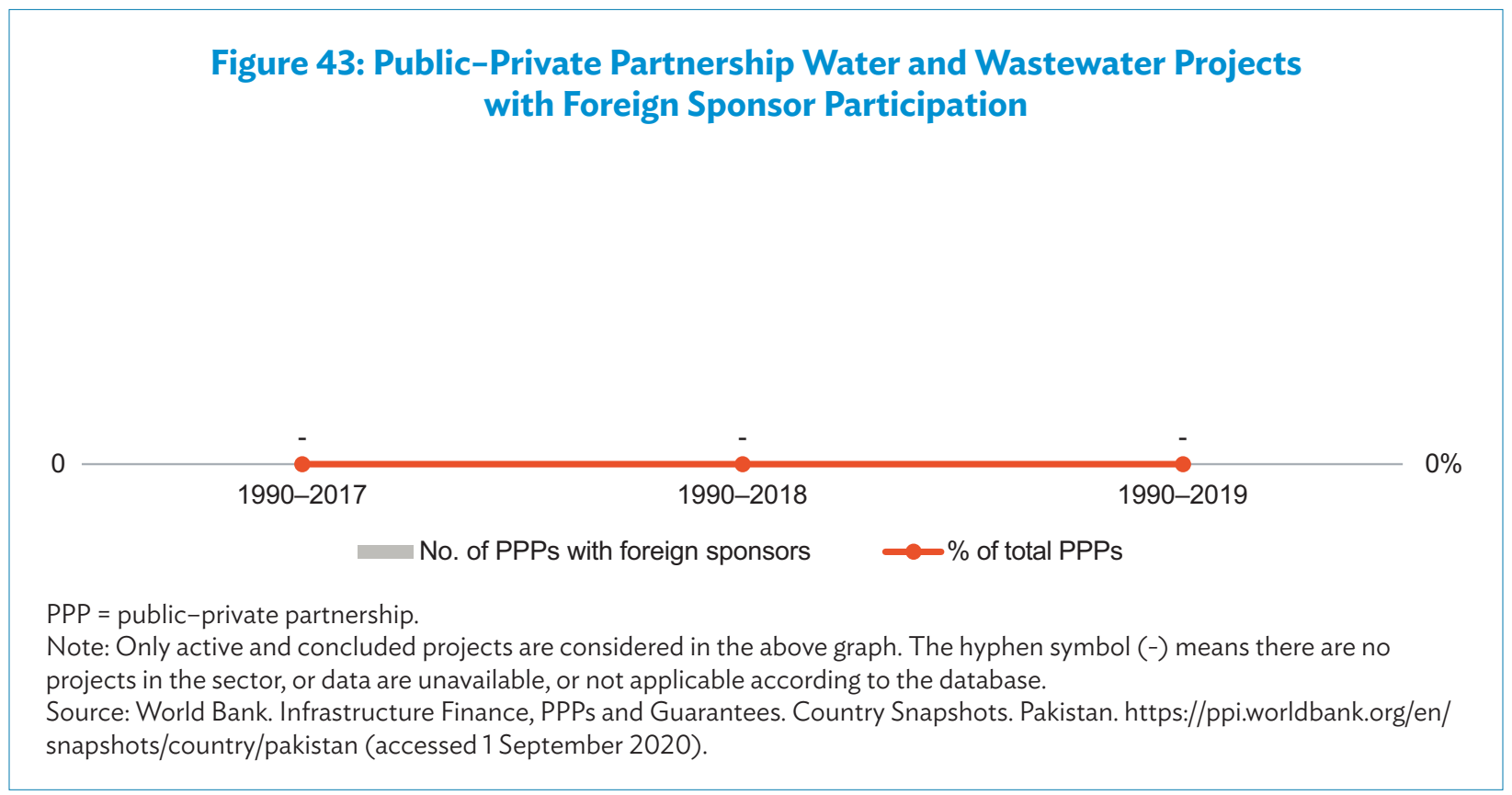

Figure 44 presents the number of PPP projects in Pakistan's water and wastewater sector that have received government support, including the VGF mechanism, government guarantees, and availability or performance payment.

Figure 44: Government Support for Public-Private Partnership Water and Wastewater Projects

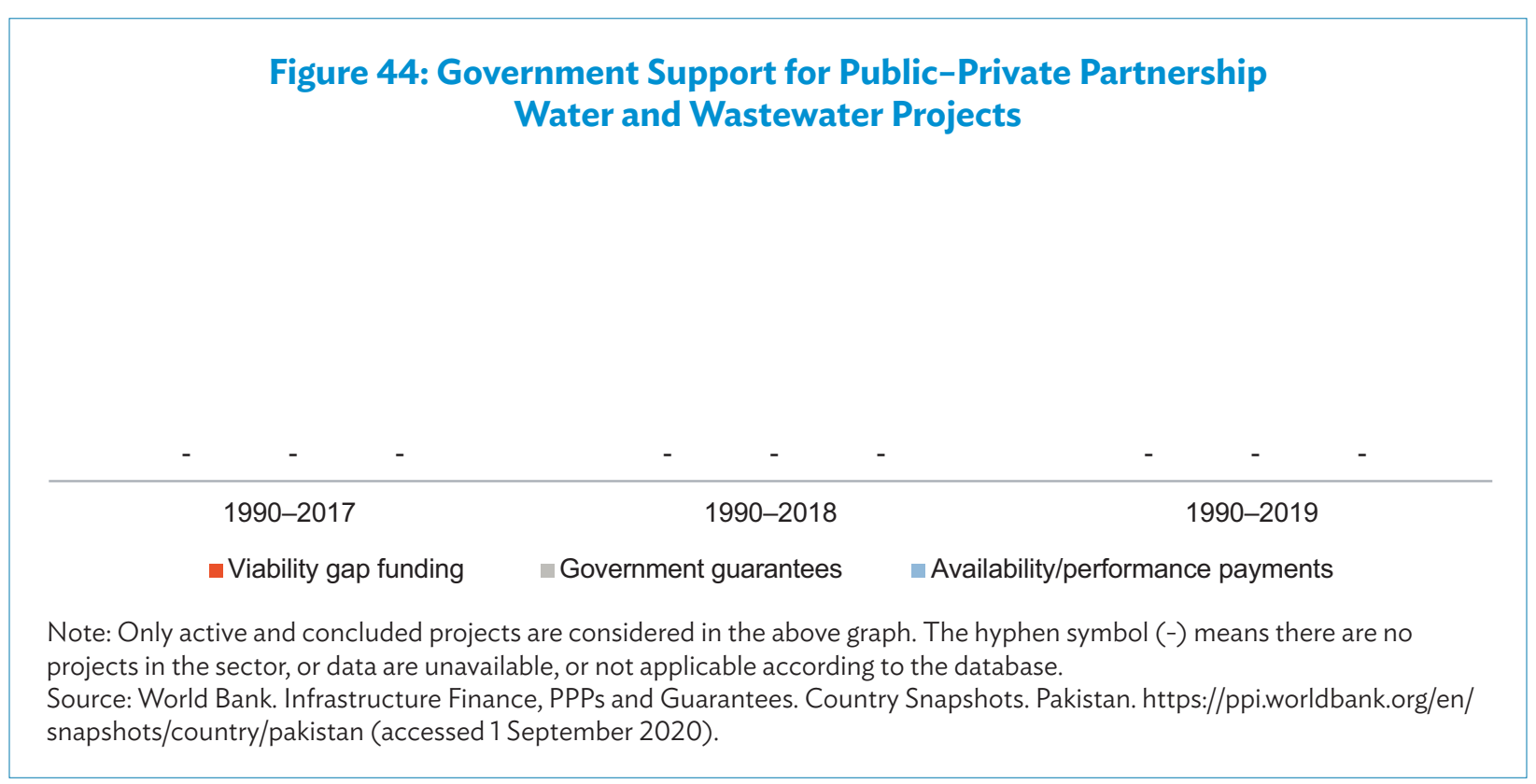

Figure 45 presents the number of PPP projects in Pakistan's water and wastewater sector that have received payment in the form of user charges and government pay (off-take). 


\section{Figure 45: Payment Mechanisms for Public-Private Partnership Water and Wastewater Projects}

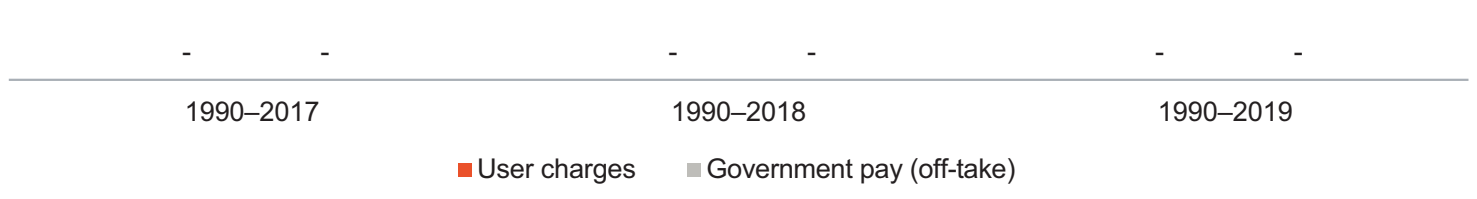

Note: Only active and concluded projects are considered in the above graph. The hyphen symbol (-) means there are no projects in the sector, or data are unavailable, or not applicable according to the database. Source: World Bank. Infrastructure Finance, PPPs and Guarantees. Country Snapshots. Pakistan. https://ppi.worldbank.org/en/ snapshots/country/pakistan (accessed 1 September 2020).

\subsection{Tariffs in the Water and Wastewater Sector}

There is no information available regarding tariffs in the water and wastewater sector.

\subsection{Typical Risk Allocation for Public-Private Partnership Projects in the Water and Wastewater Sector}

Information on risk allocation arrangements in water concession contracts is unavailable.

\subsection{Financing Detaills for Public-Private Partnership Projects in the Water and Wastewater Sector}

As no PPP projects in the water and wastewater sector have achieved financial closure till 2019, there is no information available on the financing details (Table 37).

Table 37: Financing of Public-Private Partnership Projects in the Water and Wastewater Sector

\begin{tabular}{|c|c|c|c|}
\hline Item & 1990-2017 & 1990-2018 & $1990-2019$ \\
\hline PPP projects with foreign lending participation & NA & NA & NA \\
\hline $\begin{array}{l}\text { PPP projects that received export credit agency/international financing } \\
\text { institution support }\end{array}$ & NA & NA & NA \\
\hline Typical debt-equity ratio & \multicolumn{3}{|c|}{ NA } \\
\hline Time for financial closure & \multicolumn{3}{|c|}{ NA } \\
\hline Typical concession periods & \multicolumn{3}{|c|}{ NA } \\
\hline Typical financial internal rate of return & \multicolumn{3}{|c|}{ NA } \\
\hline
\end{tabular}

NA = not applicable, PPP = public-private partnership.

Source: World Bank. Infrastructure Finance, PPPs and Guarantees. Country Snapshots. Pakistan. https://ppi.worldbank.org/en/ snapshots/country/pakistan (accessed 1 September 2020).

\section{Challenges in the Water and Wastewater Sector}

There is no information available about challenges in the water and wastewater sector. 


\section{G. INFORMATION AND COMMUNICATION TECHNOLOGY}

Subscription and coverage of Pakistan's information technology and telecommunication sector as well as assistance commitments in the sector are presented in Table 38.

Table 38: Status of Information and Communication Technology Projects

\begin{tabular}{|l|r|c|}
\hline Item & Value & Unit \\
\hline Telephone subscribers & 1.32 & per 100 inhabitants \\
\hline Cellular phone subscribers & 72.56 & per 100 inhabitants \\
\hline Cellular network coverage & 81.50 & $\%$ of population covered \\
\hline Internet subscribers & 0.85 & per 100 inhabitants \\
\hline Internet bandwidth per internet user & 5.68 & kbps \\
\hline $\begin{array}{l}\text { Total no. of projects with cumulative lending, grant, and technical assistance } \\
\text { commitments in ICT sector }\end{array}$ & 1 & no. \\
\hline $\begin{array}{l}\text { Total amount of cumulative lending, grant, and technical assistance } \\
\text { commitments in ICT sector }\end{array}$ & 1.60 & \$ million \\
\hline
\end{tabular}

\$ = United States dollar, ICT = information and communication technology, kbps = kilobits per second.

Sources: The Global Economy. Mobile Phone Subscribers, per 100 people-Country Rankings. https://www.theglobaleconomy.com/ rankings/Mobile_phone_subscribers_per_100_people/ (accessed 10 September 2020); The Global Economy. Internet Subscribers, per 100 people_Country Rankings. https://www.theglobaleconomy.com/rankings/Internet_subscribers_per_100_people/ (accessed 10 September 2020); The Global Economy. Mobile Network Coverage-Country Rankings. https://www.theglobaleconomy.com/ rankings/Mobile_network_coverage/ (accessed 10 September 2020); The Global Economy. Internet Bandwidth-Country Rankings. https://www.theglobaleconomy.com/rankings/Internet_bandwidth/ (accessed 10 September 2020); and World Bank. Data. Fixed Telephone Subscriptions. https://data.worldbank.org/indicator/IT.MLT.MAIN.P2?end=2018\&locations=MM-KH-UZ-CN-BD-GE-INID-KZ-PK-PH-LK-TH-VN\&start=2018\&view=bar (accessed 2 December 2020).

\section{Contracting Agencies in the Information and Communication Technology Sector}

The Ministry of Information Technology and Telecommunication is the overarching ministry for the information and communication technology (ICT) sector. It is responsible for the preparation of an overall integrated plan and formulation of policy for the development and improvement of information technology and telecommunications, including related infrastructure, in Pakistan.

The Pakistan Telecommunication Authority (PTA) is the sector authority responsible in regulating the establishment, operations, and maintenance of the telecommunication systems, and in providing telecommunication services in Pakistan.

\section{Information and Communication Technology Sector Laws and Regulations}

The Pakistan Telecommunication (Re-Organization) Act 1996 (with 2006 amendments) and the Pakistan Telecom Rules 2000 define the roles, mandate, and responsibility of the PTA and the telecommunications sector in Pakistan.

The latest regulatory changes in the sector include the following:

- National Information Technology Board Ordinance 2019. The reorganization of the National Information Technology Board (as an autonomous body) would not only enable harnessing the latest solutions ICTs have to offer but would also induct and mainstream these technologies in the work processes of the federal government.

- Amendments in the Pakistan Telecommunication Authority Act 2019. The amendments were made to expedite decision making, ease of doing business, delegation of authority, and decentralization.

The PTA is the regulatory authority for the telecommunications. 
The Government of Pakistan issued the Telecommunication Policy in 2015. It provides a comprehensive framework and roadmap for the regulatory and policy environment for Pakistan's telecom sector.

\subsection{Foreign Investment Restrictions in the Information and Communication Technology Sector}

The maximum allowed foreign ownership of equity in greenfield projects is shown in Table 39.

Table 39: Foreign Investment in the Information and Communication Technology Sector

\begin{tabular}{|l|c|c|c|}
\hline Item & $\mathbf{2 0 1 7}$ & $\mathbf{2 0 1 8}$ & $\mathbf{2 0 1 9}$ \\
\hline Fixed line infrastructure & $100 \%$ & $100 \%$ & $100 \%$ \\
\hline Fixed line services & $100 \%$ & $100 \%$ & $100 \%$ \\
\hline Wireless/mobile infrastructure & $100 \%$ & $100 \%$ & $100 \%$ \\
\hline Wireless/mobile services & $100 \%$ & $100 \%$ & $100 \%$ \\
\hline
\end{tabular}

Source: Asian Development Bank. 2019. Public-Private Partnership Monitor. Second Edition. Manila. https://www.adb.org/sites/default/ files/publication/509426/ppp-monitor-second-edition.pdf.

\subsection{Standard Contracts and Licenses in the Information and Communication Technology Sector}

\begin{tabular}{|l|c|}
\hline Type of Contract & Availability \\
\hline Public-private partnership/concession agreement & UA \\
\hline Performance-based operation and maintenance contract & UA \\
\hline Engineering, procurement, and construction contract & UA \\
\hline License agreement & UA \\
\hline
\end{tabular}

UA = Unavailable.

Source: Asian Development Bank. 2019. Public-Private Partnership Monitor. Second Edition. Manila. https://www.adb.org/sites/default/ files/publication/509426/ppp-monitor-second-edition.pdf.

\section{Information and Communication Technology Sector Master Plan}

Pakistan launched the Digital Pakistan Policy in 2018. In 2019, the government announced the Digital Pakistan Vision, which aims to enhance connectivity, improve digital infrastructure, increase investment in digital skills, and promote innovation and technology entrepreneurship. The Digital Policy of 2018 identifies several areas of focus, such as sector digitalization, electronic and mobile commerce, digital inclusion, e-governance, promoting innovation, entrepreneurship, and incubators or start-ups in information technology sector. The policy also highlights engaging with the private sector on PPP model for specific areas. An example is the e-Energy to Establish Public-Private Partnerships with cellular operators and utility providers using 3G/4G network for solutions such as smart grids, demand forecasting and availability of consumer portals to manage energy consumption, ICT in various segments, hardware manufacturing, and e-commerce. ${ }^{37}$

A detailed information on sector master plan in terms of specific projects pipeline is unavailable.

\section{Projects under Preparation and Procurement in the Information and Communication Technology Sector}

The information on sector master plan for projects under preparation is unavailable.

37 Government of Pakistan, Ministry of Information Technology and Telecommunication. 2018. Digital Pakistan Policy. Islamabad. http://moib.gov.pk/ Downloads/Policy/DIGITAL_PAKISTAN_POLICY(22-05-2018).pdf. 
Figure 46 presents the number of PPP projects in Pakistan's ICT sector that are under preparation and procurement.

Figure 46: Public-Private Partnership Information and Communication Technology Projects under Preparation and Procurement

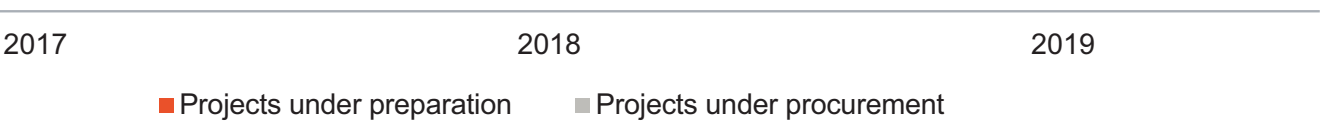

Note: The hyphen symbol (-) means there are no projects in the sector, or data are unavailable .

Source: Asian Development Bank. 2019. Public-Private Partnership Monitor. Second Edition. Manila. https://www.adb.org/sites/ default/files/publication/509426/ppp-monitor-second-edition.pdf.

\section{Features of Past Public-Private Partnership Projects in the Information and Communication Technology Sector}

There were two projects in Pakistan's ICT sector. The projects were awarded to Telenor Pakistan and Warid Telecommunications Pvt. Limited.

Figure 47 shows the number of PPP projects in Pakistan's ICT sector procured through various modes, including direct appointment, unsolicited bids, and competitive bids.

Figure 47: Modes of Procurement for Public-Private Partnership Information and Communication Technology Projects

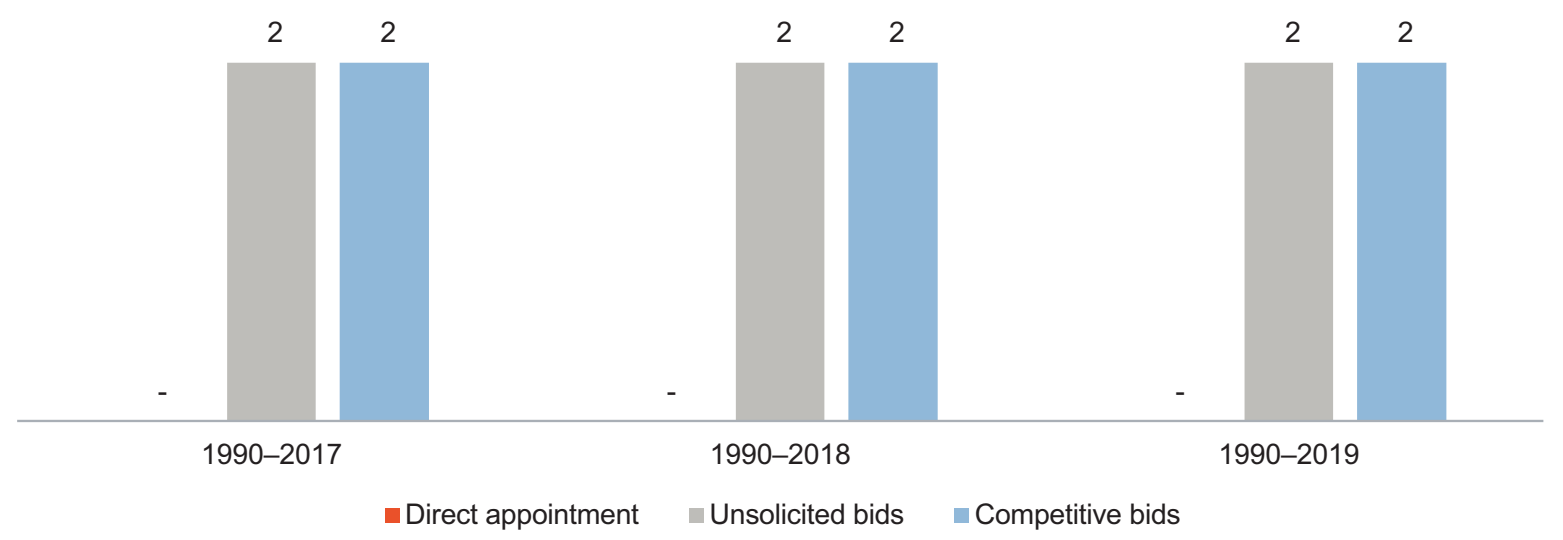

Note: Only active and concluded projects are considered in the above graph. The hyphen symbol (-) means there are no projects in the sector, or data are unavailable, or not applicable according to the database.

Source: World Bank. Infrastructure Finance, PPPs and Guarantees. Country Snapshots. Pakistan. https://ppi.worldbank.org/en/ snapshots/country/pakistan (accessed 1 September 2020). 
Figure 48 presents the number of PPP projects that have reached financial closure and, the total value of those projects in Pakistan's ICT sector.

Figure 48: Public-Private Partnership Information and Communication Technology Projects Reaching Financial Closure

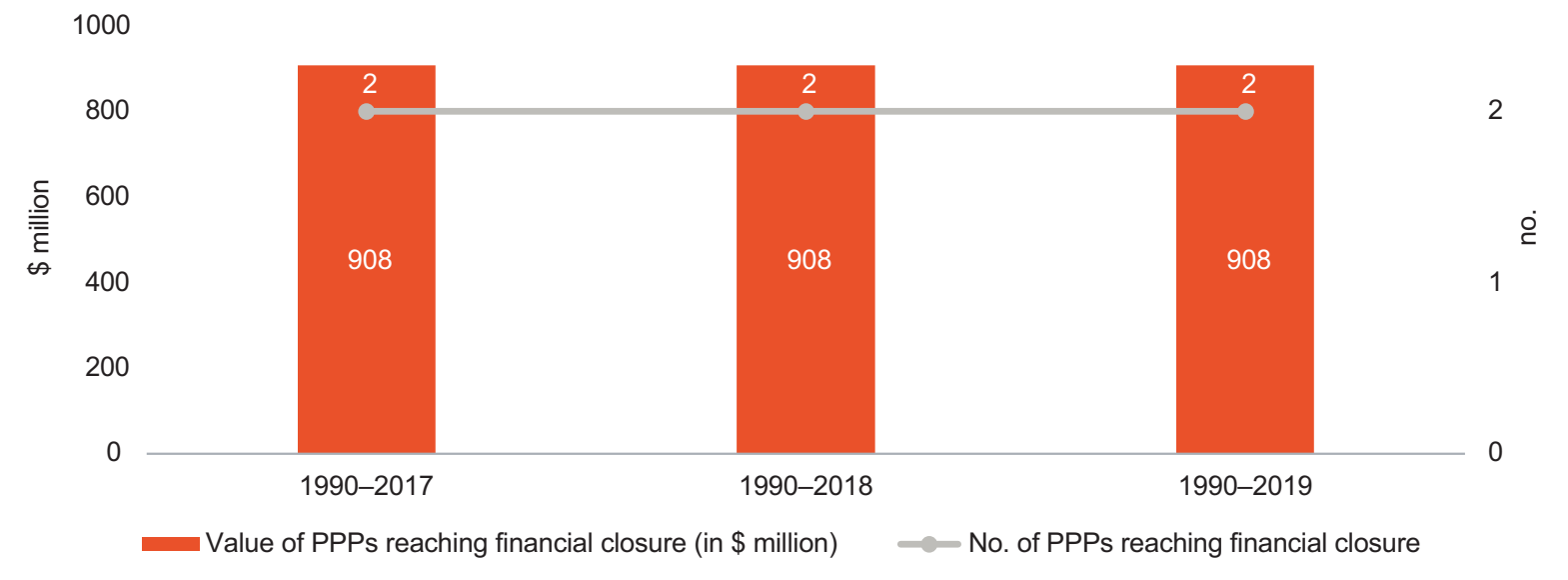

\$ = United States dollar, PPP = public-private partnership.

Note: Only active and concluded projects are considered in the above graph.

Source: World Bank. Infrastructure Finance, PPPs and Guarantees. Country Snapshots. Pakistan. https://ppi.worldbank.org/en/ snapshots/country/pakistan (accessed 1 September 2020).

Figure 49 shows the number of PPP projects that have received foreign sponsor participation in Pakistan's ICT sector.

Figure 49: Public-Private Partnership Information and Communication Technology Projects with Foreign Sponsor Participation

2

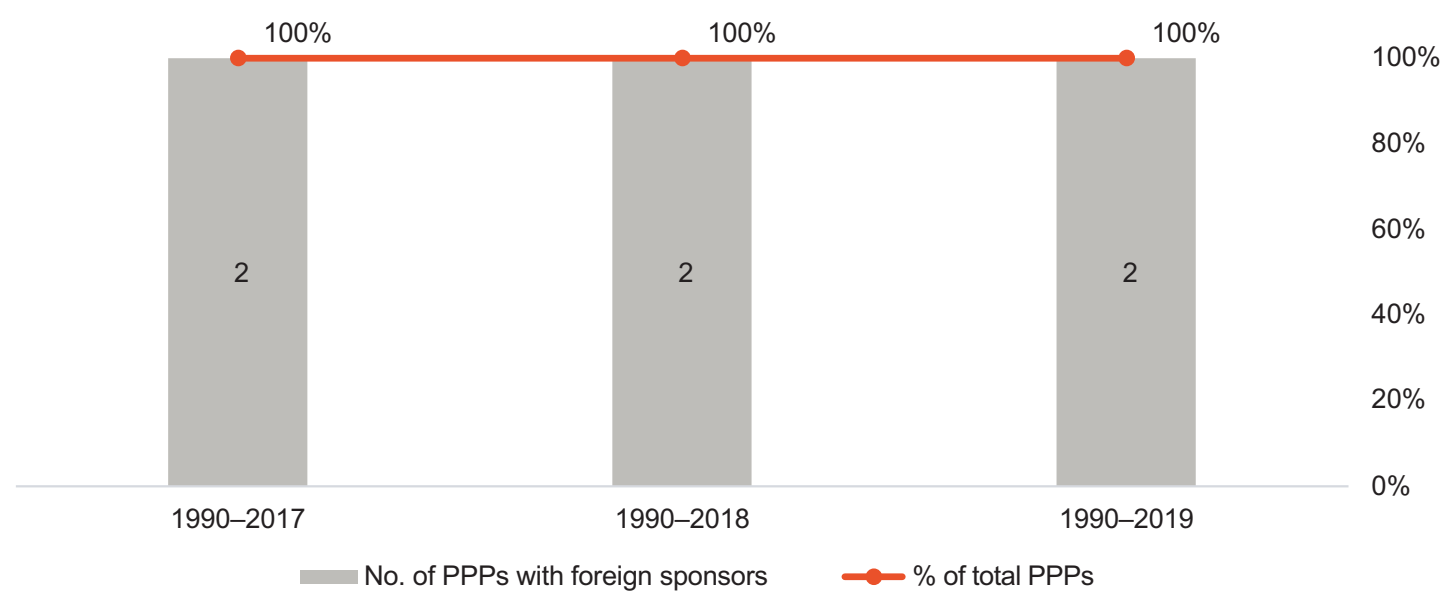

Note: Only active and concluded projects are considered in the above graph.

Source: World Bank. Infrastructure Finance, PPPs and Guarantees. Country Snapshots. Pakistan. https://ppi.worldbank.org/en/ snapshots/country/pakistan (accessed 1 September 2020). 
Figure 50 presents the number of PPP projects in Pakistan's ICT sector that have received government support, including the VGF mechanism, government guarantees, and availability or performance payment.

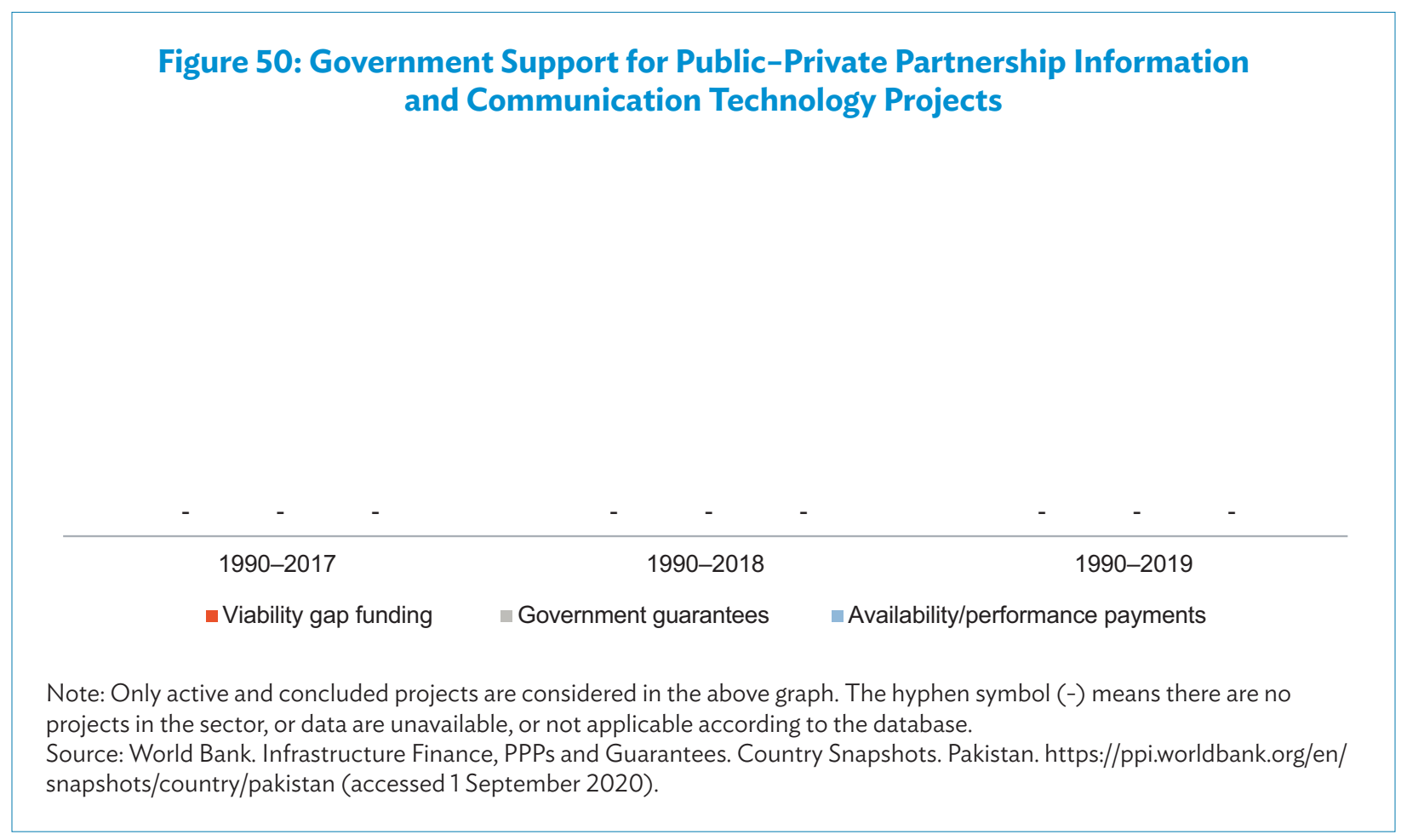

Figure 51 presents the number of PPP projects in Pakistan's water and wastewater sector that have received payment in the form of user charges and government pay (off-take).

Figure 51: Payment Mechanisms for Public-Private Partnership Information and Communication Technology Projects

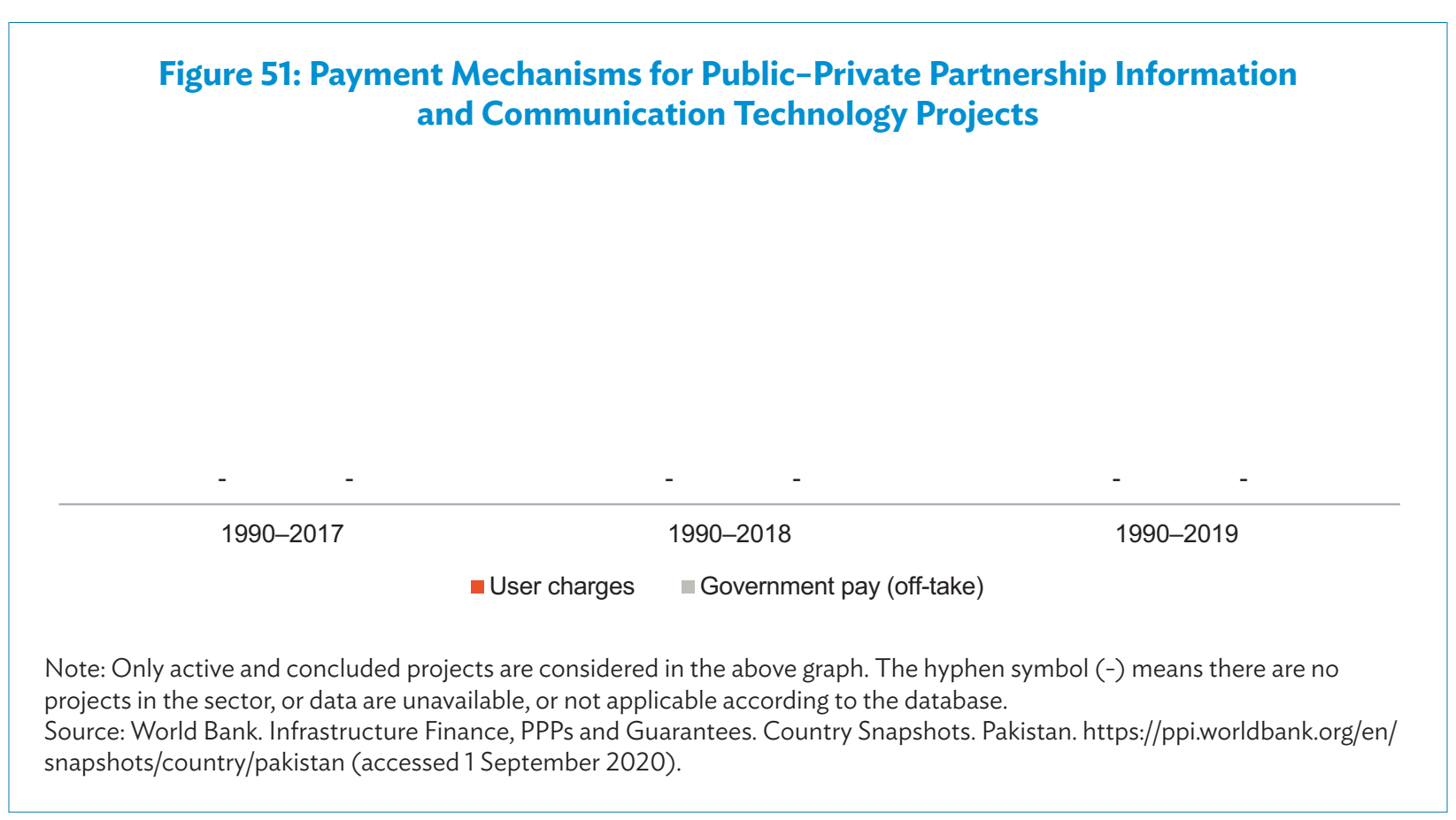




\subsection{Tariffs in the Information and Communication Technology Sector}

There is no information available regarding tariffs in the ICT sector.

\subsection{Typical Risk Allocation for Public-Private Partnership Projects in the Information and Communication Technology Sector}

The risk allocation for PPP projects in the ICT sector is unavailable.

\subsection{Financing Details for Public-Private Partnership Projects in the Information and Communication Technology Sector}

Table 40 presents the financing details of PPP ICT sector projects in Pakistan.

\section{Table 40: Financing of Public-Private Partnership Projects in the Information and Communication Technology Sector}

\begin{tabular}{|c|c|c|c|}
\hline Item & 1990-2017 & 1990-2018 & 1990-2019 \\
\hline PPP projects with foreign lending participation & $x$ & $x$ & $x$ \\
\hline $\begin{array}{l}\text { PPP projects that received export credit agency/international financing } \\
\text { institution support }\end{array}$ & $x$ & $x$ & $x$ \\
\hline Typical debt-equity ratio & \multicolumn{3}{|c|}{$\ldots$} \\
\hline Time for financial closure & \multicolumn{3}{|c|}{$\ldots$} \\
\hline Typical concession period (contract period) & \multicolumn{3}{|c|}{15 years } \\
\hline Typical financial internal rate of return & \multicolumn{3}{|c|}{$\ldots$} \\
\hline
\end{tabular}

... = data not available, $x=$ No, PPP = public-private partnership.

Source: World Bank. Infrastructure Finance, PPPs and Guarantees. Country Snapshots. Pakistan. https://ppi.worldbank.org/en/ snapshots/country/pakistan (accessed 1 September 2020).

\section{Challenges in the Information and Communication Technology Sector}

There is no available information about the challenges in the ICT sector.

\section{H. SOCIAL INFRASTRUCTURE}

Social infrastructure includes health care, education, public housing, and government buildings infrastructure. Government spending on social services and basic social indicators in Pakistan are presented in Table 41.

\section{Table 41: Status of Social Infrastructure Projects}

\begin{tabular}{|l|r|c|}
\hline Item & Value & Unit \\
\hline Government expenditure on education & 2.6 & $\%$ of GDP \\
\hline Education spending as \% of government spending & 14.5 & $\%$ \\
\hline Primary school gross enrolment & 90.0 & $\%$ \\
\hline Adult literacy rate & 58.0 & no. \\
\hline $\begin{array}{l}\text { Total no. of projects with cumulative lending, grant, and technical assistance } \\
\text { commitments in the education sector }\end{array}$ & 32 & \$ million \\
\hline $\begin{array}{l}\text { Total amount of cumulative lending, grant, and technical assistance } \\
\text { commitments in the education sector }\end{array}$ & 510.85 & \\
\hline
\end{tabular}


Table 41 continued

\begin{tabular}{|l|r|c|}
\hline Item & Value & Unit \\
\hline Total health expenditure & 2.6 & \% GDP \\
\hline Health spending per capita & 44.59 & per 100,000 live births \\
\hline Maternal mortality ratio (modeled estimates per 100,000 live births) & 170.0 & below 1 year/,000 live births \\
\hline Infant mortality rate & 69.0 & years \\
\hline $\begin{array}{l}\text { Life expectancy at birth } \\
\text { Child malnutrition }\end{array}$ & 66 & \% below 5 years old \\
\hline $\begin{array}{l}\text { Total no. of projects with cumulative lending, grant, and technical assistance } \\
\text { commitments in the health sector }\end{array}$ & 31 & no. \\
\hline $\begin{array}{l}\text { Total amount of cumulative lending, grant, and technical assistance } \\
\text { commitments in the health sector }\end{array}$ & 793.00 & \$ million \\
\hline Existing no. of affordable housing units & $\ldots$ & no. \\
\hline Affordable housing gap & $\ldots$ & \\
\hline
\end{tabular}

$\ldots=$ data not available, $\$=$ United States dollar, GDP = gross domestic product.

Sources: Asian Development Bank (ADB). 2015. Country Partnership Strategy: Pakistan, 2015-2019. Manila. https://www.adb.org/ sites/default/files/institutional-document/171824/cps-pak-2015-2019.pdf; ADB. Data Library. Cumulative Lending, Grant, and Technical Assistance Commitments. https://data.adb.org/dataset/cumulative-lending-grant-and-technical-assistance-commitments (accessed 2 December 2020); The Economist Intelligence Unit. Infrascope 2018: Pakistan Country Profile. https://infrascope.eiu.com (accessed 2 December 2020); The Global Economy. Education Spending, Percent of Government Spending-Country Rankings. https://www.theglobaleconomy.com/rankings/Education_spending_percent_of_government_spending/ (accessed 10 September 2020); and The Global Economy. Health Spending per Capita-Country Rankings. https://www.theglobaleconomy.com/rankings/ Health_spending_per_capita/ (accessed 10 September 2020).

\section{Contracting Agencies in the Social Infrastructure Sector}

Each ministry in Pakistan is responsible for PPPs in its respective sector. Line ministries, federal bodies, and provincial and local authorities as well as state-owned enterprises (SOEs) are the contracting parties on behalf of the federal government with private parties. They will therefore be responsible, mainly or in conjunction with other bodies, for the identification, selection, sponsorship, preparation, tendering, and monitoring of PPP projects in their sectors. Various government authorities have been involved in contracting social PPPs. Some examples include the following (footnote 5):

- Province of Punjab (Awarding Authority), PPP Authority;

- Province of Sindh (Awarding Authority);

- Youth Affairs, Sports, Archaeology and Tourism Department (Punjab Province);

- Primary and Secondary Healthcare Department (Punjab Province);

- Local Government and Community Development Department (Punjab Province);

- Housing Urban Development and Public Health Engineering Department (Punjab Province);

- Communication and Works Department (Punjab Province);

- Education and Literacy Department (Sindh Province);

- Health Department (Sindh Province); and

- Elementary and Secondary Education Department (Khyber Pakhtunkhwa Province).

There are numerous government authorities, line ministries, and SOEs that are able to act as the contracting authority for social PPP projects. 


\section{Social Infrastructure Sector Laws and Regulations}

According to the Pakistan Policy on Public-Private Partnerships, which provides the basis for PPP regulatory framework in Pakistan, the social sectors (education, health care, and real estate) remain unregulated (footnote 5).

\subsection{Foreign Investment Restrictions in the Social Infrastructure Sector}

The maximum allowed foreign ownership of equity in greenfield projects is shown in Table 42.

Table 42: Foreign Investment in the Social Infrastructure Sector

\begin{tabular}{|c|c|c|c|}
\hline Item & 2017 & 2018 & 2019 \\
\hline Construction of health-care facilities & $100 \%$ & $100 \%$ & $100 \%$ \\
\hline $\begin{array}{l}\text { Services, including hospital management, specialist hospital/clinic, mental } \\
\text { hospital, dental clinic, and laboratory and medical checkup services }\end{array}$ & $100 \%$ & $100 \%$ & $100 \%$ \\
\hline $\begin{array}{l}\text { Private maternity hospital, clinic general medical services/public hospital/ } \\
\text { public medical clinic, residential health services, and basic health-care } \\
\text { services facility }\end{array}$ & $100 \%$ & $100 \%$ & $100 \%$ \\
\hline Construction of education facilities & $100 \%$ & $100 \%$ & $100 \%$ \\
\hline $\begin{array}{l}\text { Nonformal education services (vocational training, computer education, and } \\
\text { language education) }\end{array}$ & $100 \%$ & $100 \%$ & $100 \%$ \\
\hline Formal education services & $100 \%$ & $100 \%$ & $100 \%$ \\
\hline Government buildings & $100 \%$ & $100 \%$ & $100 \%$ \\
\hline Prisons and correction centers & $100 \%$ & $100 \%$ & $100 \%$ \\
\hline Public housing & $100 \%$ & $100 \%$ & $100 \%$ \\
\hline Other sectors (waste disposal) & $100 \%$ & $100 \%$ & $100 \%$ \\
\hline
\end{tabular}

Source: Asian Development Bank. 2019. Public-Private Partnership Monitor. Second Edition. Manila. https://www.adb.org/sites/default/ files/publication/509426/ppp-monitor-second-edition.pdf.

\subsection{Standard Contracts in the Social Infrastructure Sector}

\begin{tabular}{|l|c|}
\hline Type of Contract & Availability \\
\hline Public-private partnership/concession agreement & UA \\
\hline Performance-based operation and maintenance contract & UA \\
\hline Engineering, procurement, and construction contract & UA \\
\hline
\end{tabular}

$\checkmark=$ Yes, $x=$ No, NA = Not Applicable, UA = Unavailable.

a Education Management Organisation (EMO) models are performance-based.

Source: Asian Development Bank. 2019. Public-Private Partnership Monitor. Second Edition. Manila. https://www.adb.org/sites/default/ files/publication/509426/ppp-monitor-second-edition.pdf.

\section{Social Infrastructure Sector Master Plan}

At the provincial level, almost every province has sector master plans for education and health. However, no consolidated master plan for social infrastructure could be found at the national level.

\section{Projects under Preparation and Procurement in the Social Infrastructure Sector}

The details of the sector project plans for the social infrastructure sector are unavailable at the federal level. The provincial governments have been substantially active in promoting and developing PPPs. This is especially true for the provinces of Punjab, Sindh, and Khyber Pakhtunkhwa. PPP pipelines are available to a greater extent on 
a provincial level in comparison to a federal level. The PPP pipeline of social projects is available on the PPP Cell website on behalf of the Province of Punjab, and the PPP Unit on behalf of the Province of Sindh (footnote 5).

The projects, mainly in Punjab, that are under preparation and in the pipeline in the social infrastructure and other sectors not covered in the earlier sections are ${ }^{38}$

- Model Town Housing Scheme, Sargodha; and

- Naya Pakistan Housing Project, Chiniot (Area Development Scheme-II).

Figure 52 shows the number of PPP projects in Pakistan's social infrastructure sector that are under preparation and procurement.

Figure 52: Public-Private Partnership Social Infrastructure Projects under Preparation and Procurement

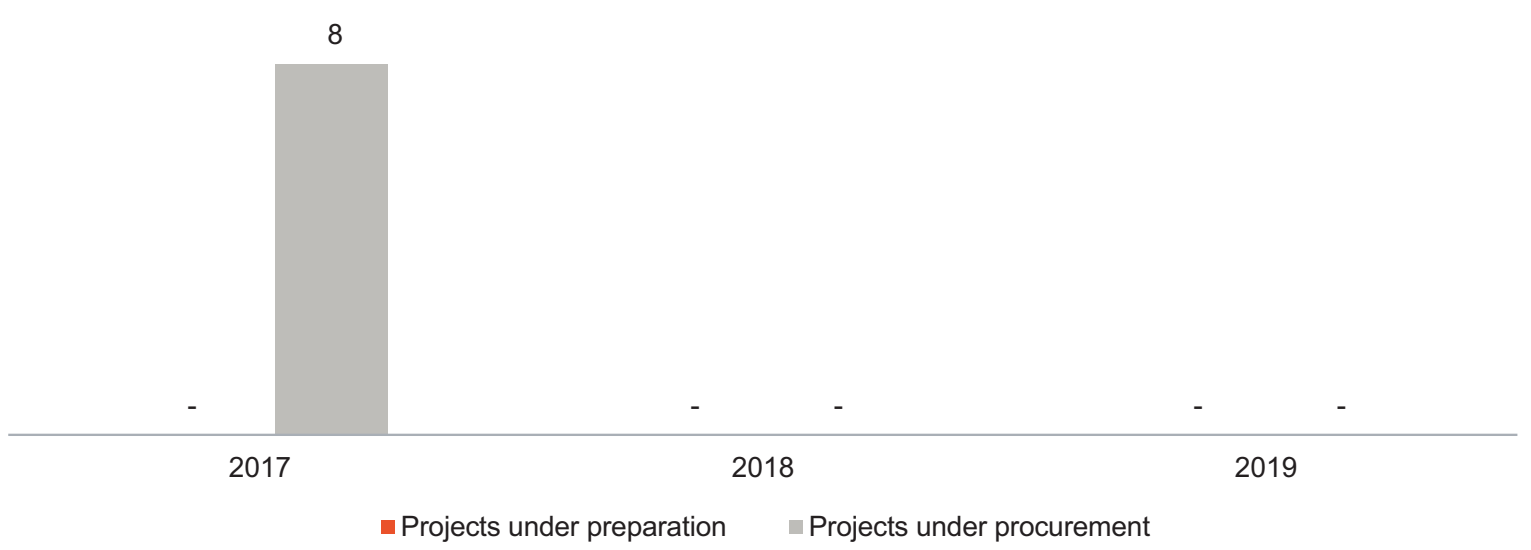

Note: The hyphen symbol (-) means there are no projects in the sector, or data are unavailable. Source: Asian Development Bank. 2019. Public-Private Partnership Monitor. Second Edition. Manila. https://www.adb.org/sites/ default/files/publication/509426/ppp-monitor-second-edition.pdf.

\section{Features of Past Public-Private Partnership Projects in the Social Infrastructure Sector}

A project undertaken in Punjab Province is included under the social infrastructure sector in the second edition of the PPP Monitor. The PPP for Punjab Grain Storage Facilities is a solicited proposal, which aims to develop multigrain storage and handling facilities under a 10-year build-own-transfer contract. The Food Department of the provincial government of Punjab procured the project. The private operator receives fixed service charges from the government agency. The project is indicative of the development of the PPP model within the provinces in Pakistan through different ministries and government agencies (footnote 5). However, the World Bank PPI database does not showcase past projects in the social infrastructure.

To ensure consistency of data source, the succeeding figures (Figures 53-57) reflect the information available from the World Bank PPP database.

38 Provincial Government of Punjab, Pakistan; Planning and Development Board, PPP Cell. Pipeline Projects. https://ppp.punjab.gov.pk/pipeline_ projects (accessed 21 September 2021). 
Figure 53 presents the number of PPP projects in Pakistan's social infrastructure sector, procured through various modes, including direct appointment, unsolicited bids, and competitive bids.

Figure 53: Modes of Procurement for Public-Private Partnership Social Infrastructure Projects

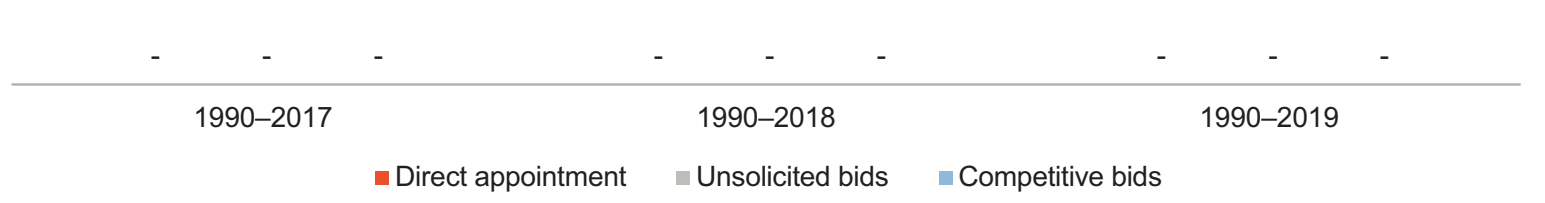

Note: Only active and concluded projects are considered in the above graph. The hyphen symbol (-) means there are no projects in the sector, or data are unavailable, or not applicable according to the database.

Source: World Bank. Infrastructure Finance, PPPs and Guarantees. Country Snapshots. Pakistan. https://ppi.worldbank.org/en/ snapshots/country/pakistan (accessed 1 September 2020).

Figure 54 provides the number of PPP projects in Pakistan's social infrastructure sector that have reached financial closure, and the total value of those projects.

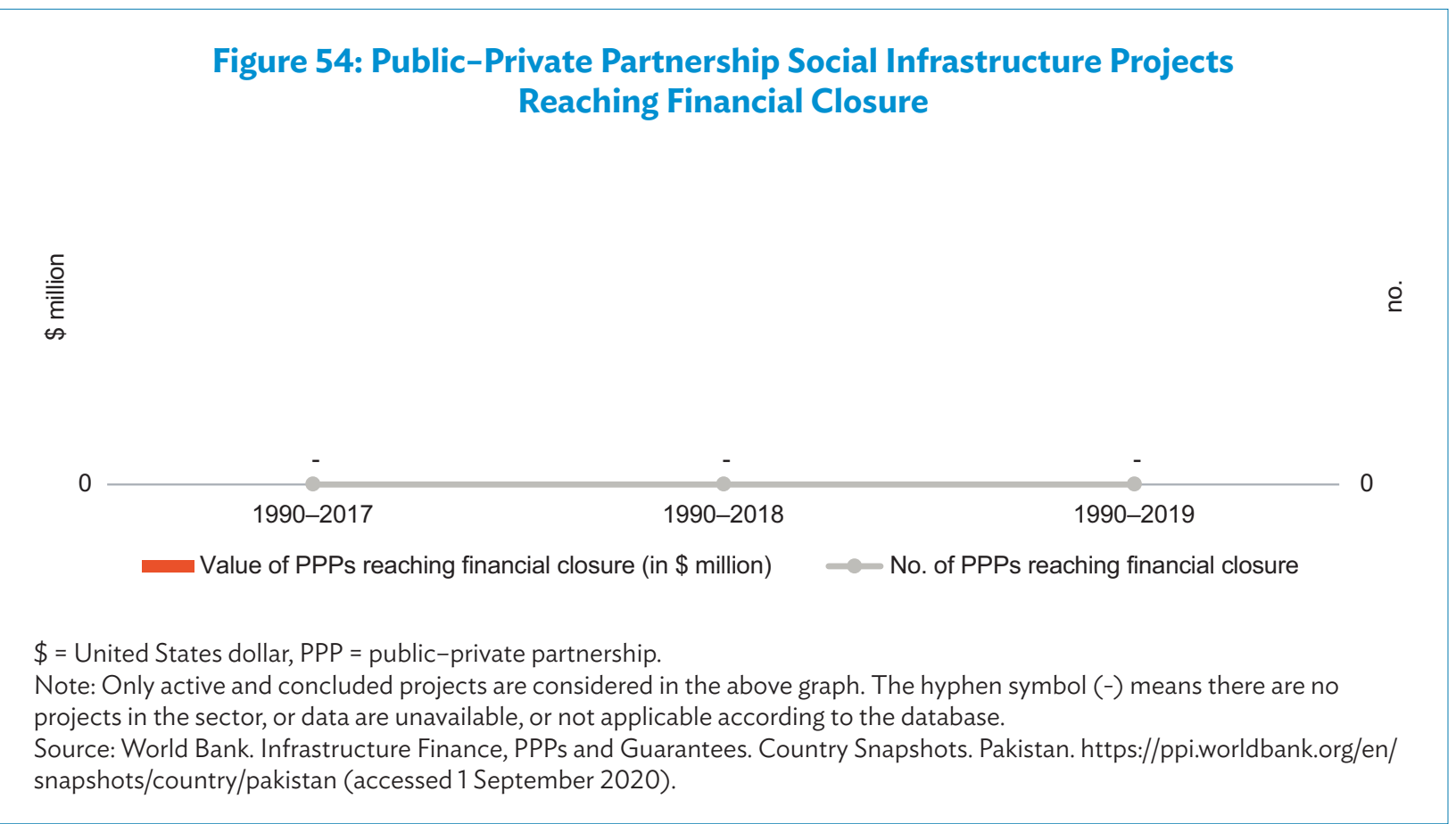


Figure 56 shows the number of PPP projects in Pakistan's social infrastructure sector that have received foreign sponsor participation.

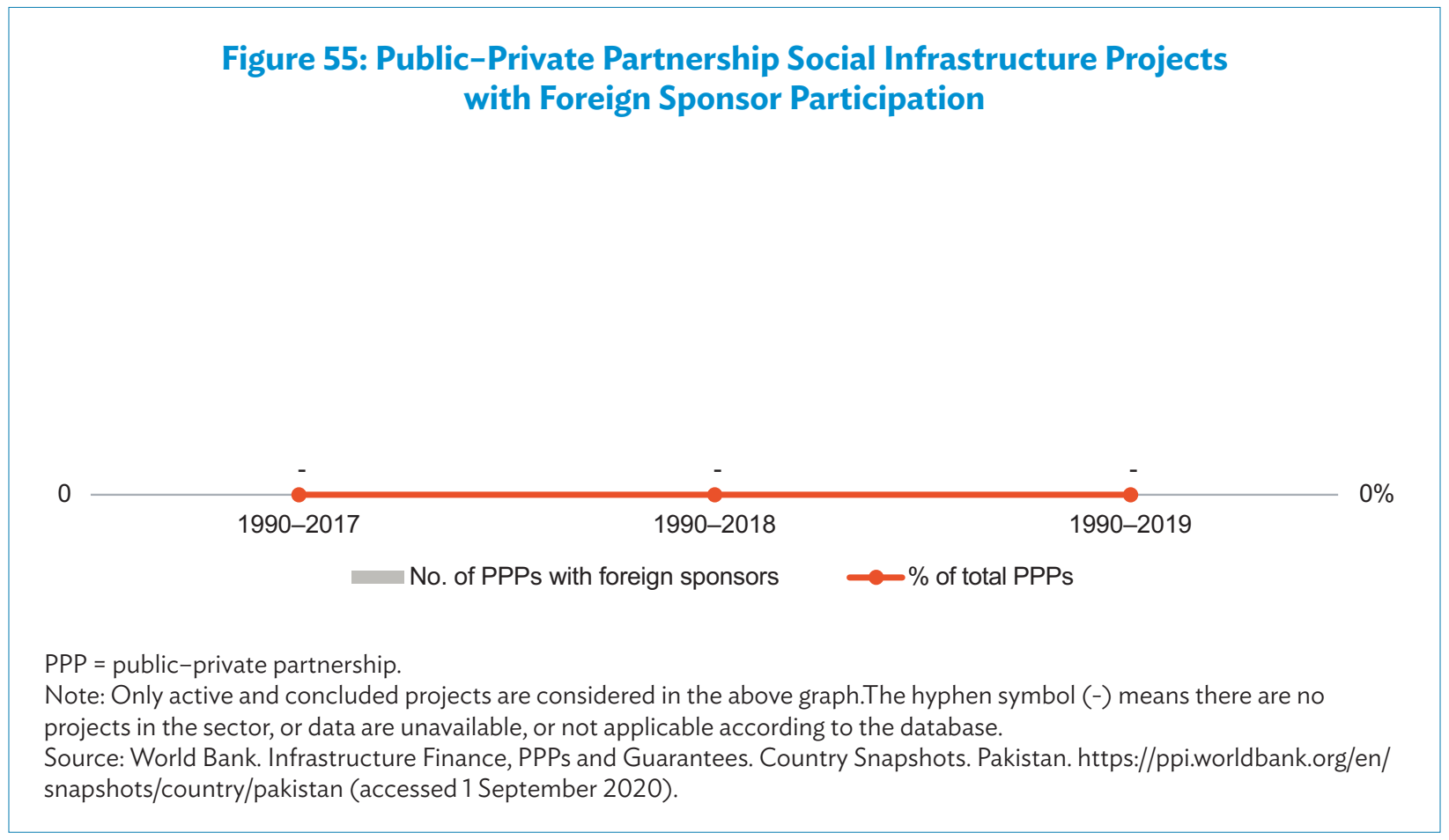

Figure 56 presents the number of PPP projects in Pakistan's social infrastructure sector that have received government support, including the viability gap funding (VGF) mechanism, government guarantees, and availability or performance payment.

Figure 56: Government Support to Public-Private Partnership Social Infrastructure Projects

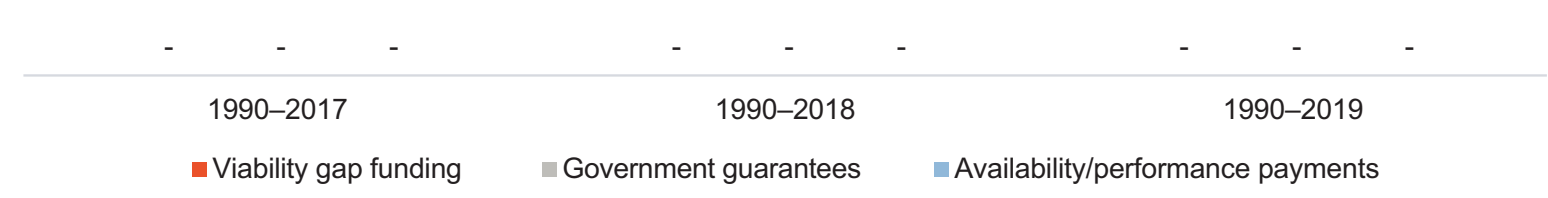

Note: Only active and concluded projects are considered in the above graph. The hyphen symbol (-) means there are no projects in the sector, or data are unavailable, or not applicable according to the database.

Source: World Bank. Infrastructure Finance, PPPs and Guarantees. Country Snapshots. Pakistan. https://ppi.worldbank.org/en/ snapshots/country/pakistan (accessed 1 September 2020). 
Figure 57 shows the number of PPP projects in Pakistan's social infrastructure sector that have received payment in the form of user charges and government pay (off-take).

Figure 57: Payment Mechanisms for Public-Private Partnership Social Infrastructure Projects

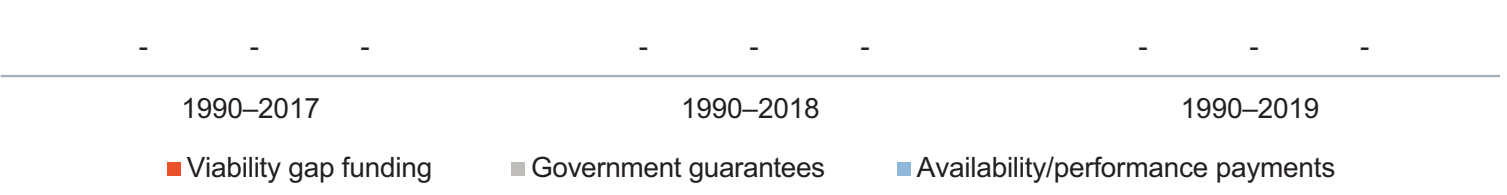

Note: Only active and concluded projects are considered in the above graph. The hyphen symbol (-) means there are no projects in the sector, or data are unavailable, or not applicable according to the database.

Source: World Bank. Infrastructure Finance, PPPs and Guarantees. Country Snapshots. Pakistan. https://ppi.worldbank.org/en/ snapshots/country/pakistan (accessed 1 September 2020).

\subsection{Tariffs in the Sociall Infrastructure Sector}

Information on the tariffs for social infrastructure projects is unavailable.

\subsection{Typical Risk Allocation for Public-Private Partnership Projects in the Social Infrastructure Sector}

Information on the typical risk allocation for social infrastructure projects is unavailable.

\subsection{Financing Details for Public-Private Partnership Projects in the Social Infrastructure Sector}

As no PPP projects in the social infrastructure sector have achieved financial closure till 2019, there is no information available on the financing details (Table 43).

Table 43: Financing of Public-Private Partnership Projects in the Social Infrastructure Sector

\begin{tabular}{|c|c|c|c|}
\hline Item & 1990-2017 & 1990-2018 & 1990-2019 \\
\hline PPP projects with foreign lending participation & NA & NA & NA \\
\hline $\begin{array}{l}\text { PPP projects that received export credit agency/international financing } \\
\text { institution support }\end{array}$ & NA & NA & NA \\
\hline Typical debt-equity ratio & \multicolumn{3}{|c|}{ NA } \\
\hline Time for financial closure & \multicolumn{3}{|c|}{ NA } \\
\hline Typical concession period & \multicolumn{3}{|c|}{ NA } \\
\hline Typical financial internal rate of return & \multicolumn{3}{|c|}{ NA } \\
\hline
\end{tabular}

NA = not applicable, $P P P=$ public - private partnership.

Source: World Bank. Infrastructure Finance, PPPs and Guarantees. Country Snapshots. Pakistan. https://ppi.worldbank.org/en/ snapshots/country/pakistan (accessed 1 September 2020).

\section{Challenges in the Social Infrastructure Sector}

The following challenges are observed (footnote 5):

- Inadequate regulatory framework capacity,

- Lack of experience and regulatory environment in social infrastructure development,

- Misalignment of PPP support for social infrastructure projects between the various provinces in Pakistan, and

- Existing PPP social infrastructure investments have had mixed results and have overexploited public infrastructure usage instead of enhancing access to health and education services. 


\section{OTHER INFRASTRUCTURE}

Other infrastructure includes municipal solid waste (MSW) or non-waste-to-energy sector.

\section{Contracting Agencies in the Other Infrastructure Sector}

The Planning and Development Division at the federal level, and the planning and development departments at the provincial levels are responsible for preparing development plans and allocating resources for the MSW. The responsibility of solid waste management, therefore, falls under the purview of the respective provincial governments. Under the recent local government system, the tehsil (town) municipal administrations are responsible for solid waste collection, transportation, and disposal.

\section{Other Infrastructure Sector Laws and Regulations}

At the federal level, the Ministry of Environment is responsible for developing environmental policies and programs. The Pakistan Environmental Protection Agency (EPA) and the provincial EPAs are the main regulatory bodies for implementing the 1997 Pakistan Environmental Protection Act (PEPA). ${ }^{39}$ The PEPA provides the framework for establishing the federal and provincial EPAs.

The National Environmental Action Plan aims to initiate actions and programs for achieving a state of the environment that safeguards public health. It was approved by the Pakistan Environment Protection Council in $2001{ }^{40}$

\subsection{Foreign Investment Restrictions in the Other Infrastructure Sector}

The maximum equity investment allowed for foreign investors in greenfield projects is 100\% (Table 44).

Table 44: Foreign Investment in the Other Infrastructure Sector

\begin{tabular}{|l|c|c|c|}
\hline Item & $\mathbf{2 0 1 7}$ & $\mathbf{2 0 1 8}$ & 2019 \\
\hline Maximum allowed foreign ownership of equity in greenfield projects & $100 \%$ & $100 \%$ & $100 \%$ \\
\hline
\end{tabular}

Source: Asian Development Bank. 2019. Public-Private Partnership Monitor. Second Edition. Manila. https://www.adb.org/sites/default/ files/publication/509426/ppp-monitor-second-edition.pdf.

\subsection{Standard Contracts in the Other Infrastructure Sector}

Type of Contract

Public-private partnership/concession agreement

Performance-based operation and maintenance contract

Engineering, procurement, and construction contract

$\checkmark=$ Yes, $x=$ No, NA = Not Applicable, UA = Unavailable.

Source: Asian Development Bank. 2019. Public-Private Partnership Monitor. Second Edition. Manila. https://www.adb.org/sites/default/ files/publication/509426/ppp-monitor-second-edition.pdf.
Availability

UA

UA

UA

39 Government of Pakistan, Pakistan Environmental Protection Agency (formerly under the defunct Ministry of Environment, and now under the Ministry of Climate Change). n.d. Brief on Solid Waste Management in Pakistan. Islamabad. http://www.environment.gov.pk/images/ environmentalissues/BriefSWMPak.pdf.

40 Government of Pakistan, Pakistan Environmental Protection Agency (formerly under the defunct Ministry of Environment, and now under the Ministry of Climate Change). 2005. Draft Guidelines for Solid Waste Management. Islamabad. http://www.environment.gov.pk/images/ provincialsepasguidelines/SWMGLinesDraft.pdf. 


\section{Other Infrastructure Sector Master Plan}

There is no available information on the master plan for this sector.

\section{Projects under Preparation and Procurement in the Other Infrastructure Sector}

The list of MSW projects under preparation and procurement is unavailable at the federal and provincial level.

However, there are infrastructure projects in the provinces of Punjab and Sindh that are not included in the earlier sections. They are listed below (footnote 16):

Punjab:

- Establishment of a weaving city at M-3 Industrial Estate Faisalabad, Punjab;

- Development of tourist resort or entertainment park at Uchali Lake, Soon Valley, District Khushab;

- Multimodal intercity bus terminals in Lahore;

- Establishment of a model cattle market in Lahore;

- Vehicle inspection and certification system for private vehicles in Punjab;

- Procurement, installation, and maintenance of weighing equipment, and operation and management of permanent weigh stations;

- Establishment of women hostels in major cities of Punjab;

- Construction of the Multipurpose Parking Plaza with International Level Hostel for Players, 05 Star Hotel, and Museum in Nishtar Park Sports Complex, Lahore;

- Establishment of a sports complex in Multan;

- Operations and maintenance of the sports facilities in Punjab, Phases I and II;

- Citizen facilitation and service centers in Southern Punjab;

- Construction of two additional stories at the existing Parking Plaza, Fawara Chowk, Rawalpindi;

- Construction of a parking plaza with shopping mall at the Old Mayer House, Faisalabad;

- Construction of a parking-cum-commercial plaza at the commercial market, Satellite Town, Rawalpindi;

- Construction of a parking-cum-commercial plaza at Banni Market, Rawalpindi; and

- Construction of a parking-cum-commercial plaza at the Old Rawalpindi MC Office Site Jinnah Road, Rawalpindi.

Sindh:

- Arfa Karim IT Media City Project,

- Dhabeji Pumping Station,

- Domicile and PRC Automation Project,

- Larkana Fruit and Vegetable Mandi,

- Marble City Project,

- NED Technology Park, and

- TP-1 and TP-4 wastewater treatment plants. 
Figure 58 shows the number of PPP projects in Pakistan's social infrastructure sector (particularly, in the MSW sector) that are under preparation and procurement.

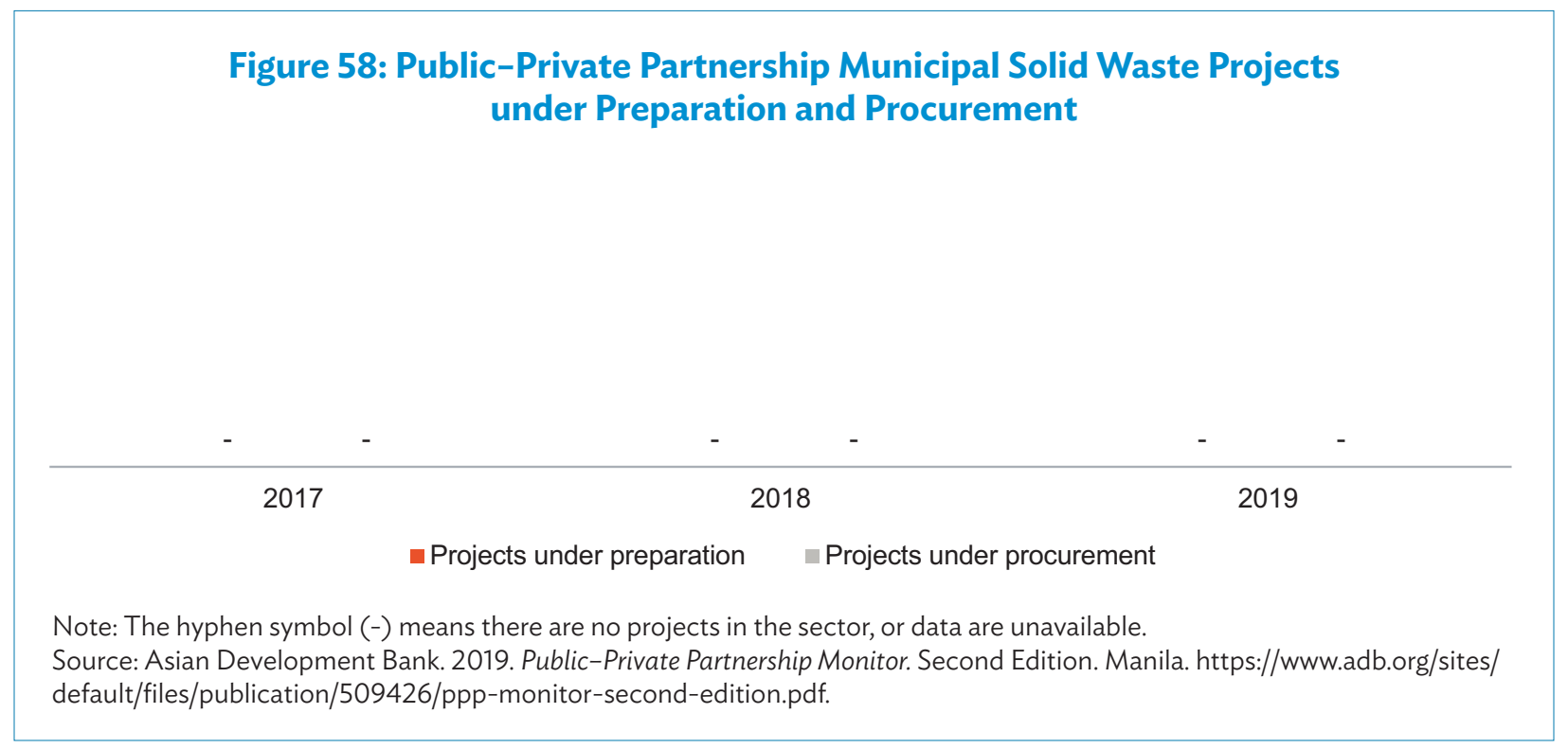

\section{Features of Past Public-Private Partnership Projects in the Other Infrastructure Sector}

There was one project taken up in the MSW sector in 2012-the Lakhodair Landfill Facility in Lahore.

Figure 59 presents the number of PPP projects in Pakistan's MSW sector, procured through various modes, including direct appointment, unsolicited bids, and competitive bids.

Figure 59: Modes of Procurement for Public-Private Partnership Municipal Solid Waste Projects

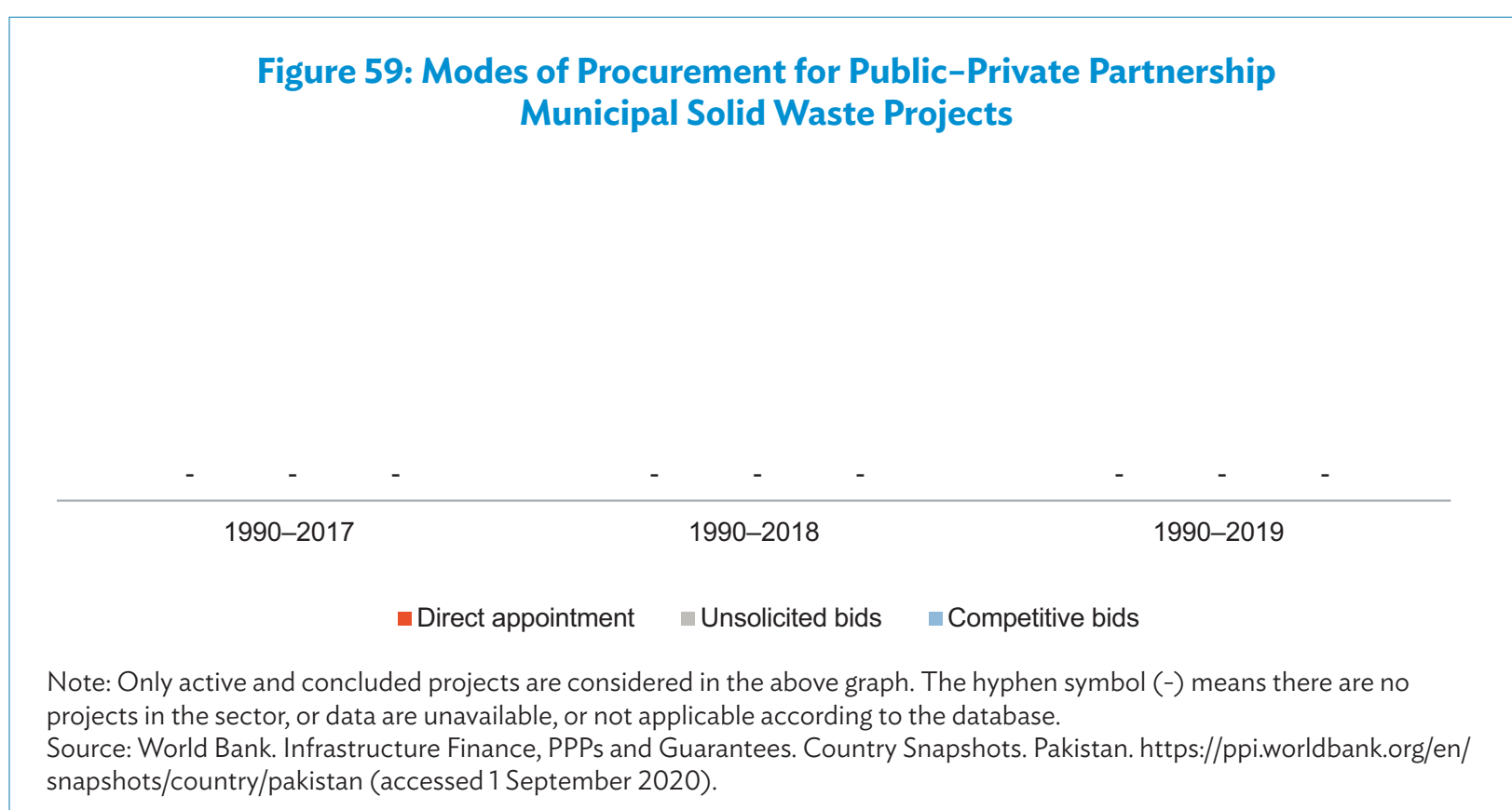


Figure 60 provides the number of PPP projects in Pakistan's MSW sector that have reached financial closure, and the total value of those projects.

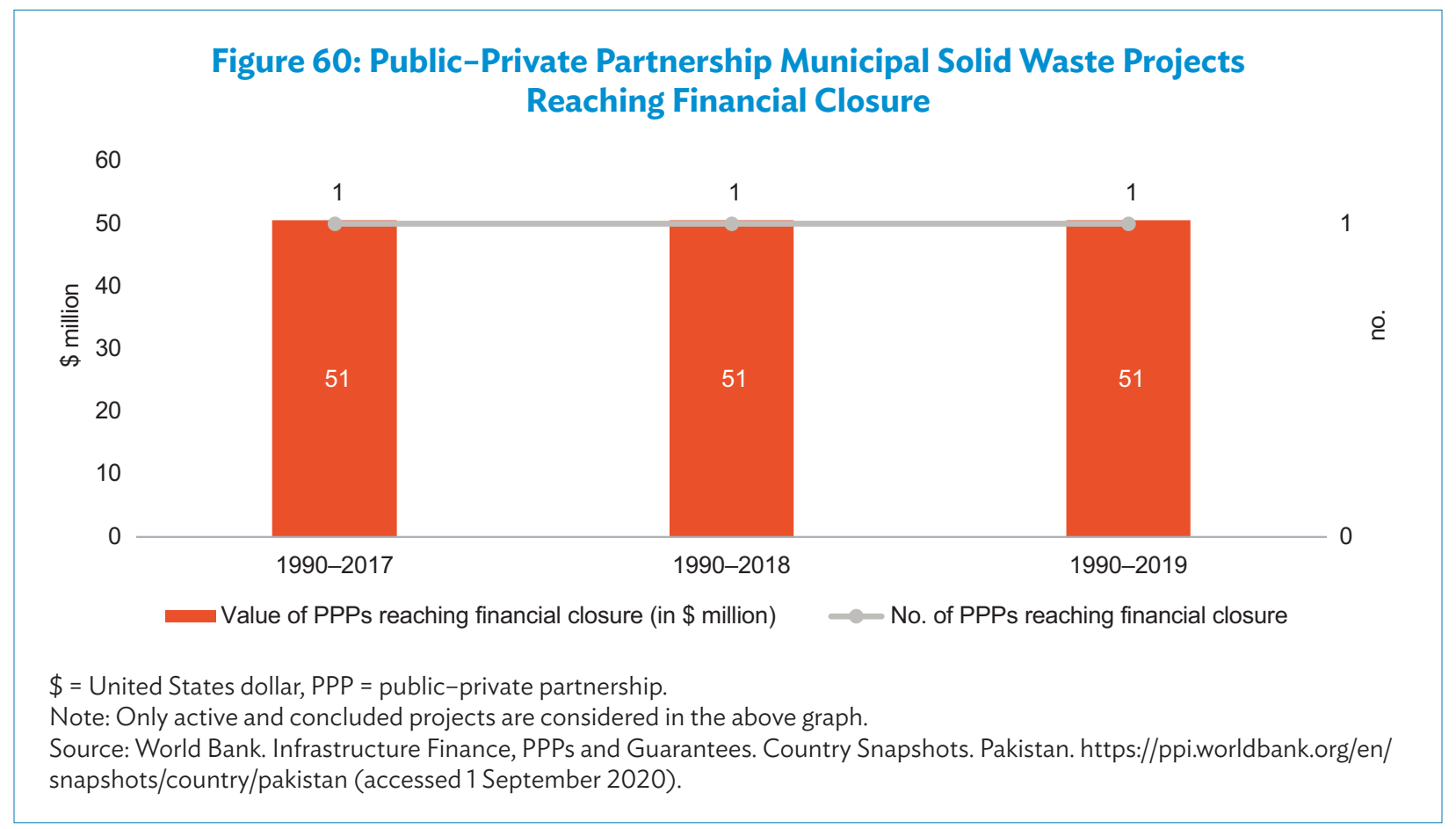

Figure 61 shows the number of PPP projects in Pakistan's MSW sector that have received foreign sponsor participation.

\section{Figure 61: Public-Private Partnership Municipal Solid Waste Projects with Foreign Sponsor Participation}

0

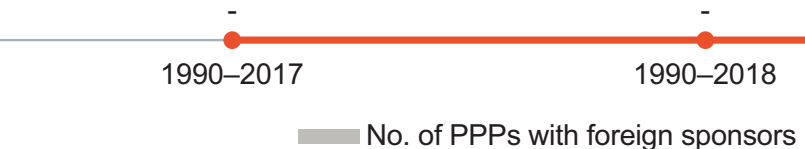

PPP = public-private partnership.

Note: Only active and concluded projects are considered in the above graph. The hyphen symbol (-) means there are no projects in the sector, or data are unavailable, or not applicable according to the database.

Source: World Bank. Infrastructure Finance, PPPs and Guarantees. Country Snapshots. Pakistan. https://ppi.worldbank.org/en/ snapshots/country/pakistan (accessed 1 September 2020). 
Figure 62 presents the number of PPP projects in Pakistan's MSW sector that have received government support, including the VGF mechanism, government guarantees, and availability or performance payment.

Figure 62: Government Support to Public-Private Partnership Municipal Solid Waste Projects

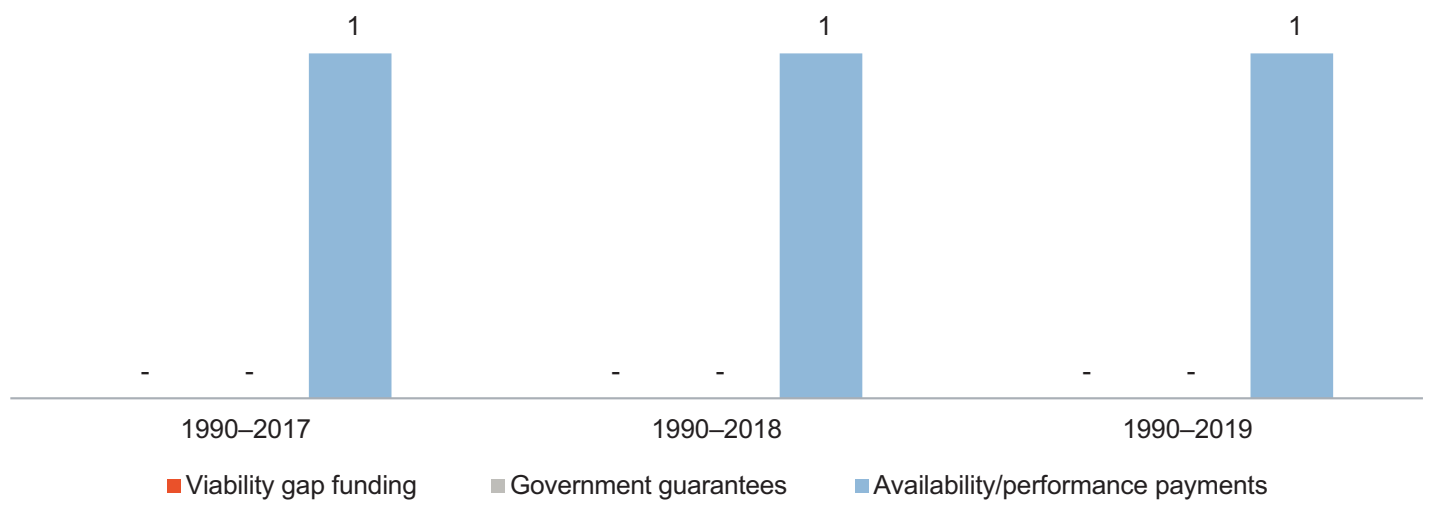

Note: Only active and concluded projects are considered in the above graph. The hyphen symbol (-) means there are no projects in the sector, or data are unavailable, or not applicable according to the database.

Source: World Bank. Infrastructure Finance, PPPs and Guarantees. Country Snapshots. Pakistan. https://ppi.worldbank.org/en/ snapshots/country/pakistan (accessed 1 September 2020).

Figure 63 shows the number of PPP projects in Pakistan's MSW sector that have received payment in the form of user charges and government pay (off-take).

\section{Figure 63: Payment Mechanisms for Public-Private Partnership Municipal Solid Waste Projects}

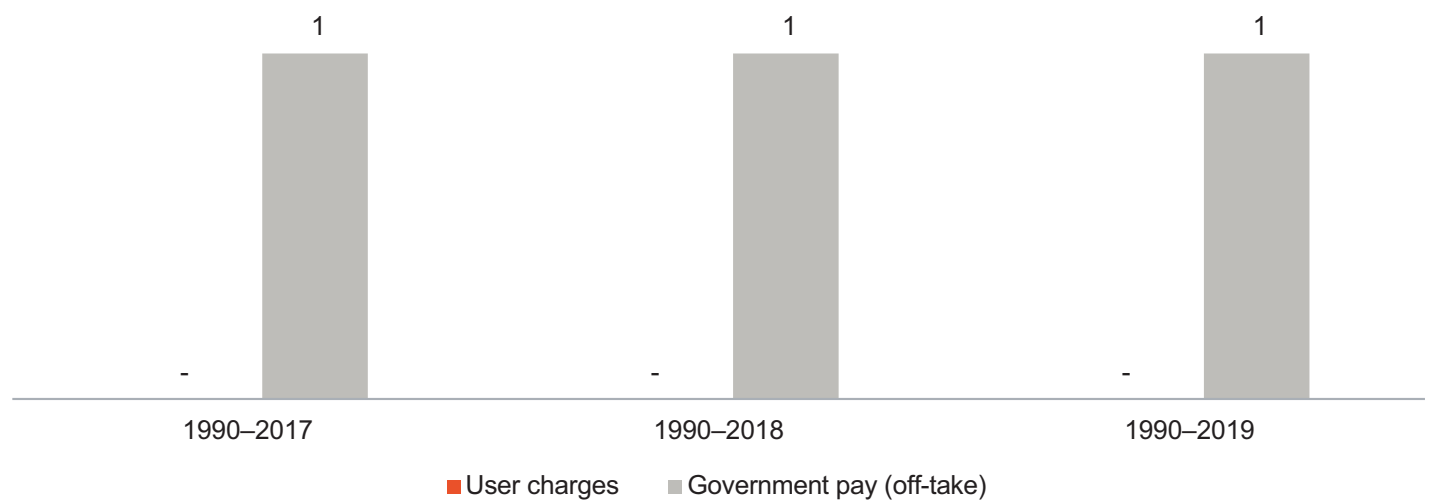

Note: Only active and concluded projects are considered in the above graph. The hyphen symbol (-) means there are no projects in the sector, or data are unavailable, or not applicable according to the database.

Source: World Bank. Infrastructure Finance, PPPs and Guarantees. Country Snapshots. Pakistan. https://ppi.worldbank.org/en/ snapshots/country/pakistan (accessed 1 September 2020). 


\subsection{Tariffs in the Other Infrastructure Sector}

Information on the tariffs for municipal solid waste projects is unavailable.

\subsection{Typical Risk Allocation for Public-Private Partnership Projects in the Other Infrastructure Sector}

Information on the typical risk allocation for the sector is unavailable.

\subsection{Financing Details for Public-Private Partnership Projects in the Other Infrastructure Sector}

Table 45 presents the financing details of PPP projects in the other infrastructure sector (particularly, MSW) of Pakistan.

Table 45: Financing of Public-Private Partnership Projects in the Municipal Solid Waste Sector

\begin{tabular}{|c|c|c|c|}
\hline Item & 1990-2017 & 1990-2018 & 1990-2019 \\
\hline PPP projects with foreign lending participation & $x$ & $x$ & $x$ \\
\hline $\begin{array}{l}\text { PPP projects that received export credit agency/international financing } \\
\text { institution support }\end{array}$ & $x$ & $x$ & $x$ \\
\hline Typical debt-equity ratio & & $\ldots$ & \\
\hline Time for financial closure & & $\ldots$ & \\
\hline Typical concession period & & $\ldots$ & \\
\hline Typical financial internal rate of return & & $\ldots$ & \\
\hline
\end{tabular}

$\ldots=$ data not available, $\mathrm{x}=$ No, $\mathrm{PPP}=$ public-private partnership.

Source: World Bank. Infrastructure Finance, PPPs and Guarantees. Country Snapshots. Pakistan. https://ppi.worldbank.org/en/ snapshots/country/pakistan (accessed 1 September 2020).

\section{Challenges in the Other Infrastructure Sector}

The waste management sector in Pakistan is challenged with a wide range of social, cultural, legislative, and economic issues. In the country, more waste is being produced than the number of facilities available to manage it. Some of the major problems are

- lack of proper waste collection system,

- dumping of waste on the streets,

- lack of waste segregation systems,

- uncontrolled sanitary landfill sites (open burning is common), and

- lack of awareness among citizens about the impact of reckless waste disposal on environmental and public health problems. ${ }^{41}$

Other challenges hindering sector growth include the absence of strong regulatory system, and lack of experience of public and private sector in designing and implementing projects.

41 BioEnergy Consult. 2020. Solid Waste Management in Pakistan. https://www.bioenergyconsult.com/solid-waste-management-in-pakistan/ (accessed 1 September 2020). 


\section{Local Government Public- Private Partnership Landscape}

Table 46 presents a list of parameters for assessing the public financial management profile of Pakistan's local governments.

Table 46: Public Financial Management Profile of Pakistan's Subnational Governments

\begin{tabular}{|c|c|c|}
\hline Parameter & Value & Unit \\
\hline \multicolumn{3}{|l|}{ Number of Subnational Governments } \\
\hline - Municipal level & $\ldots$ & no. \\
\hline - Intermediate level & $\ldots$ & no. \\
\hline - Regional or state level & $\ldots$ & no. \\
\hline Total number of SNGs & $\ldots$ & no. \\
\hline \multicolumn{3}{|l|}{ SNG Expenditure Profile } \\
\hline Total SNG expenditure as $\%$ of GDP & $\ldots$ & $\%$ \\
\hline - SNG current expenditure as $\%$ of GDP & $\ldots$ & $\%$ \\
\hline - SNG staff expenditure as $\%$ of GDP & $\ldots$ & $\%$ \\
\hline - SNG investment as \% of GDP & $\ldots$ & $\%$ \\
\hline $\begin{array}{l}\text { Total SNG expenditure as \% of the total general government expenditure } \\
\text { (\% of total public expenditure) }\end{array}$ & $\ldots$ & $\%$ \\
\hline $\begin{array}{l}\text { - SNG current expenditure as a \% of total current expenditure of the general } \\
\text { government }\end{array}$ & $\ldots$ & $\%$ \\
\hline $\begin{array}{l}\text { - SNG staff expenditure as a \% of total staff expenditure of the general } \\
\text { government }\end{array}$ & $\ldots$ & $\%$ \\
\hline - SNG investment as a \% of total investment of the general government & $\ldots$ & $\%$ \\
\hline Current expenditure of SNG as a \% of total SNG expenditure & $\ldots$ & $\%$ \\
\hline Staff expenditure of SNG as a $\%$ of total SNG expenditure & $\ldots$ & $\%$ \\
\hline Investments of SNG as a \% of total SNG expenditure & $\ldots$ & $\%$ \\
\hline \multicolumn{3}{|l|}{ SNG Expenditure by Function } \\
\hline - General public services & $\ldots$ & $\%$ \\
\hline - Defense & $\ldots$ & $\%$ \\
\hline - Security and public order & $\ldots$ & $\%$ \\
\hline - Economic affairs & $\ldots$ & $\%$ \\
\hline - Environmental protection & $\ldots$ & $\%$ \\
\hline - Housing and community amenities & $\ldots$ & $\%$ \\
\hline - Health & $\ldots$ & $\%$ \\
\hline
\end{tabular}


Table 46 continued

\begin{tabular}{|c|c|c|}
\hline Parameter & Value & Unit \\
\hline - Recreation, culture, and religion & $\ldots$ & $\%$ \\
\hline - Education & $\ldots$ & $\%$ \\
\hline - Social protection & $\ldots$ & $\%$ \\
\hline \multicolumn{3}{|l|}{ SNG Revenue Profile } \\
\hline Total SNG revenue as a $\%$ of GDP & $\ldots$ & $\%$ \\
\hline - SNG tax revenue as a $\%$ of GDP & $\ldots$ & $\%$ \\
\hline - SNG grants and subsidies as a $\%$ of GDP & $\ldots$ & $\%$ \\
\hline - SNG other revenues as a \% of GDP & $\ldots$ & $\%$ \\
\hline Total SNG revenue as \% of total general government revenue & $\ldots$ & $\%$ \\
\hline - SNG tax revenue as a $\%$ of total general government tax revenue & $\ldots$ & $\%$ \\
\hline $\begin{array}{l}\text { - SNG grants and subsidies as a \% of total general government grants and } \\
\text { subsidies }\end{array}$ & $\ldots$ & $\%$ \\
\hline - SNG other revenues as a $\%$ of total other revenues & $\ldots$ & $\%$ \\
\hline SNG tax revenue as a $\%$ of total SNG revenue & $\ldots$ & $\%$ \\
\hline SNG grants and subsidies as a $\%$ of total SNG revenue & $\ldots$ & $\%$ \\
\hline SNG other revenues as a \% of total SNG revenue & $\ldots$ & $\%$ \\
\hline \multicolumn{3}{|l|}{ SNG Debt Profile } \\
\hline Outstanding SNG debt as \% of GDP & $\ldots$ & $\%$ \\
\hline Outstanding SNG debt as \% of total outstanding debt of general government & $\ldots$ & $\%$ \\
\hline \multicolumn{3}{|l|}{ Parameters for Transfers to the SNGs from the National Government } \\
\hline Score on transfers to SNGs & A & \\
\hline - Score on system for allocating transfers & A & \\
\hline - Score on timeliness of information on transfers & $\mathrm{B}$ & \\
\hline $\begin{array}{l}\text { - Score on extent of collection and reporting of consolidated fiscal data for } \\
\text { general government }\end{array}$ & A & \\
\hline Value of central government transfers to SNGs & $\ldots$ & $\%$ of GDP \\
\hline Value of actual budgetary allocation to SNGs from national government & $\ldots$ & $\begin{array}{l}\% \text { of total } \\
\text { expenditure }\end{array}$ \\
\hline Value of deviation of actual against the budgeted transfers to SNGs & $\ldots$ & $\begin{array}{l}\% \text { of budgeted } \\
\text { transfers }\end{array}$ \\
\hline
\end{tabular}

... = data not available, GDP = gross domestic product, $\mathrm{SNG}=$ subnational government.

Note: The Public Financial Management and Accountability Assessment report, developed by the World Bank and other development partners, comprised scoring of various indicators by rating them from $A$ to $D$. These ratings, as per criteria stated in the Public Expenditure and Financial Accountability (PEFA) framework, are broadly interpreted as follows:

$A=$ good performance that meets international standards (i.e., the criteria for the indicator are met in a complete, orderly, accurate, timely, and coordinated way);

$B=$ a level of performance ranging from good to medium by international standards;

$C=$ a level of performance ranging from medium to poor; and

$D=a$ process or procedure that is either nonexistent or not functioning effectively.

Sources: PEFA. Pakistan 2012. https://www.pefa.org/assessments/summary/1536; and United Cities and Local Governments (UCLG) and Organisation for Economic Co-operation and Development (OECD). 2016. Subnational Governments Around the World: Structure and Finance. Part III-Country Profiles. A joint study of UCLG and OECD. https://www.uclg.org/sites/default/files/global_ observatory_of_local_finance-part_iii.pdf. 


\section{LOCAL GOVERNANCE SYSTEM IN PAKISTAN}

Pakistan is a federal republic with three tiers of government: national, provincial, and local. The local government is protected by the Constitution in Articles 32 and 140-A. Each province has its own local-government-enabling legislation and ministries responsible for implementation. District councils and metropolitan corporations are respectively the highest rural and urban tiers of local government in the provinces. Both urban and rural local government have two or three tiers in all provinces except Khyber Pakhtunkhwa, where councils are identified as neither urban nor rural. There are 129 district councils across the four provinces, 619 urban councils made up of one city district, 4 metropolitan corporations, 13 municipal corporations, 96 municipal committees, 148 town councils, 360 urban union committees, and 1,925 rural councils. Additionally, there are 3,339 neighborhood, tehsil, and village councils in Khyber Pakhtunkhwa. The ability to raise local revenue varies according to provincial legislation. ${ }^{42}$

Despite the issuance of Ordinance 2001, development of local governments in Pakistan is limited, and the local government in most parts of Pakistan is empowered by provincial legislation. The provincial governments and their local government laws, along with the amendments, are outlined below: ${ }^{43}$

- The Punjab Local Government Act 2019 (Act XIII of 2019), passed on 4 May 2019 (amendment of the Punjab Local Government [Amendment] Act of 2013);

- The Khyber Pakhtunkhwa Local Government (Second Amendment) Act 2020, passed on 7 July 2020;

- Sindh Local Government (Amendment) Act 2019, amended up to 27 February 2019 (amendment of the Sindh Local Government Act [Amendment] 2017); and

- The Balochistan Local Government (Amendment) Bill No. 08 of 2019, passed on 30 March 2019 (amendment of Balochistan Local Government Act 2010).

The duration, structure, election processes, powers, and functions of the local governments vary from province to province. The amendments of 2019 and 2020 have led to several changes in the structure and functioning of the local and provincial governments' rights. For example, the Punjab Local Government Act 2019 has changed the classification of urban local governments. It classifies nine cities as metropolitan corporations. The remaining urban areas with a population of 75,000 or more and urban areas designated as tehsil headquarters have been classified as municipalities. The Act also recognizes urban areas with a population of 20,000 or more that are not in the previous two categories as town committees. The Act has also created a separation of executive and legislative functions, which is another important feature of a strong mayor-council model. The amended Act has also introduced a provision that requires the provincial government of Punjab to devolve at least $26 \%$ of its general revenue receipts to elected local governments, which is a significant variation from earlier Act of 2013 as it will increase the funds available to elected local governments by eight times compared to the amount disbursed in 2017-2018. ${ }^{44}$ default/assets/File/Country_profiles/Pakistan.pdf

43 Pakistan Institute of Legislative Development and Transparency. 2019. Briefing Paper: Comparative Analysis of Local Government Laws in Pakistan. Islamabad. https://pildat.org/wp-content/uploads/2019/04/ComparativeAnalysisofLocalGovernmentLawsinPakistan.pdf.

44 G. Bryan, A. Cheema, A. Jamal, A. Khan, A. Liaqat, and G. Padro i Miquel. 2019. State Capacity in Punjab's Local Governments: Benchmarking Existing Deficits. S-37433-PAK-2. London: International Growth Centre. https://www.theigc.org/wp-content/uploads/2020/08/Bryan-et-al-2019-Finalreport_update.pdf. 
Besides the local government act, there are various provincial cities acts that were passed in the 1970s in all four provinces. The objective is to manage large cities and establish special purpose vehicles such as the Development Authorities and Water and Sanitation Agencies in major cities above 1 million population. These acts were subsequently revised in many provinces including Punjab in 2019 and Khyber Pakhtunkhwa in 2020 (Khyber Pakhtunkhwa Urban Areas Authorities Act 2020). Further, Punjab 2019 and Khyber Pakhtunkhwa 2020 also passed their water acts (which have major implication on the local government functions) and regulatory systems related to water and sanitation services and options for outsourcing.

\section{Infrastructure Development Plan of Local Governments}

Although there are variations by province, districts normally have the responsibility for delivering elementary and secondary education, literacy, primary and secondary health and dispensaries, and agriculture and intradistrict roads. The responsibilities of tehsils include local roads and streets, street services (e.g., lighting, water supply systems, sewers and sanitation); slaughterhouses; and fairs, markets, and cultural events. Metropolitan corporations (previously city districts) provide integrated services, managing these on a citywide basis to achieve economies of scale. Councils at the union level are responsible for libraries, local streets and street services, wells and ponds, and cattle ponds and grazing areas. Union guards responsible for local security may be appointed (footnote 42).

\section{Sectors Where Local Governments Can Implement Public-Private Partnerships}

There are variations in the sectors that each local government could implement. For example, the law of Balochistan defines the local government functions to include "public health, water supply, drains, animals and cattle, primary education, public safety, town planning, [and] building control" (footnote 43).

Khyber Pakhtunkhwa, on the other hand, devolves much more detailed functions and indicates that "local governments are responsible for municipal services defined in the law and devolved administrative and financial authority for the management of the offices of government, to the district government, including primary and secondary education; mother and child health-care centers; basic health units; rural health centers; social welfare; sports, culture and youth affairs; revenue and estate; agriculture; livestock; on-farm water management; soil conservation; fisheries cooperatives; hospitals other than district headquarters; teaching and tertiary hospitals; rural development and rural works; population welfare coordination; human resource management; [and] planning, development, finance and budgeting functions for the devolved offices" (footnote 43).

\section{Revenues for Local Governments}

The ability to raise local revenue varies according to provincial legislation (footnote 42). Different provincial laws allow for different sets of taxes and duties to be levied and collected as revenues by the local governments. For example, the Punjab Law provides a list of items, including "any tax, fee, rate, rent, toll, charge or surcharge only after the provincial government vets the tax proposal and approves it. Taxes include tax on the transfer of immovable property, entertainment tax on drama and theatrical shows, fees for registration and certification of births and marriages, services provided by various tiers, [and] community tax" (footnote 43).

Likewise, the Balochistan Law provides that "each tier, subject to the approval by the Provincial Government, levy all or any of the taxes prescribed by the government such as on cinemas [and] entertainment; registration and certification of birth, marriages, and deaths; licenses, sanctions, and permits granted by each tier of local government; transfer of immovable property; annual rental value of buildings and land; birth of children; marriage; advertisement and billboards; [and] animals and sale of animals" (footnote 43). 


\section{Borrowings by Local Governments}

In raising their own sources of revenue, each local government has laws that restrict the power of elected local government officials from imposing taxes and prohibit them from incurring any debt (footnote 43).

\section{Budgetary Allocation to Local Governments}

Each provincial law makes elected local governments excessively reliant on provincial discretion of funding. In Punjab, Khyber Pakhtunkhwa, and Sindh, provincial finance commissions are composed largely of provincial ministers and public servant with nominal representation from elected local governments and members of the provincial assemblies. Meanwhile in Balochistan, the authority of the Grants Committee rests with the provincial ministers and secretaries (footnote 43).

In Punjab, the provincial government retains the authority to review the approved budget of a local government and, if found contrary to the budget rules, may require the local government to rectify it. The law prohibits a local government from incurring any debt without previous approval of the provincial government. A local government may invest surplus funds, if any, in securities and financial institutions approved by the provincial government. In Khyber Pakhtunkhwa, the Provincial Finance Commission makes recommendations to the provincial government on the amount of grant for local governments out of the proceeds of the Provincial Consolidated Fund in a financial year. The Sindh law states that the Provincial Finance Commission shall take all decisions by majority of the members present and voting, while the provincial government retains the authority to approve or, for reasons to be recorded in writing, alter the recommendations of the Commission. The Balochistan Local Government Act provides for the setting up of a Local Councils Grants Committee to award grants to local governments (footnote 43).

An assessment of the country's public financial management system is presented in the box below.

\section{Box: Assessment of Pakistan's Public Financial Management and Accountability System}

The latest assessment of the Public Financial Management System (PFMS), based on the Public Expenditure and Financial Accountability (PEFA) framework of 2012, states that Pakistan has an overall rating of $A$ (on a four-point rating scale, with $A$ as the best and $D$ as the worst) in terms of the country's transparency in intergovernmental fiscal relations. ${ }^{a}$ The subindicators used to establish this overall rating are as follows:

- Transparent and rules-based systems in the horizontal allocation of unconditional and conditional transfers among lower-level governments - having a rating of $A$ (on a similar four-point rating scale);

- Timeliness of information on transfers - having a rating of $B$ (on a similar four-point rating scale); and

- Extent of consolidation of fiscal data for general government according to sectoral categories-having a rating of $A$ (on a similar four-point rating scale).

A new PEFA assessment for 2020 is being prepared, which may review the above parameters, but is yet unavailable.

A structured rule-based allocation system governs the allocations to and among subnational governments in Pakistan under the direction of the National Finance Commission (NFC). The NFC award is the distribution of financial resources among the provinces of Pakistan by the federal government on an annual basis. Certain types of taxes collected by the federal government are pooled and then redistributed according to the NFC formula. Allocations from shares in federal taxes are made through a divisible pool, with shares being determined by the NFC award. The provincial share of the divisible pool would increase from $47.5 \%$ to $56 \%$ in the first fiscal year of the NFC award (FY2010) and $57.5 \%$ in the remaining years of the award. Provincial governments follow the same budgeting calendar as the federal government (i.e., Budget Call Circular is issued in November/December each year and budgets are to be finalized in May/June).

a Further details on the PEFA assessment of the PFMS in Pakistan is available at https://www.pefa.org/country/pakistan. Source: PEFA. 2012. Pakistan Federal Government: Public Financial Management and Accountability Assessment. Report No. 69185PK. Islamabad: World Bank Pakistan. https://openknowledge.worldbank.org/handle/10986/26816. 


\section{Credit Rating of Local Governments}

No specific information on the credit rating of local governments was available. However, given that none of the four local governments reviewed are allowed to borrow money, it may be presumed that none of the local governments have credit ratings.

\section{CASE STUDY: VEHICLE INSPECTION AND CERTIFICATION SYSTEM IN PUNJAB}

The case details are extracted from the Request for Proposal document issued by the Transport Department, Provincial Government of Punjab, Pakistan and from the Public-Private Partnership (PPP) Project Digest 2017 published by the PPP Cell, Provincial Government of Punjab. ${ }^{45}$

\section{Background}

The Transport Department of the Provincial Government of Punjab aims to upgrade the vehicle inspection and certification system (VICS) in Punjab. A project has been conceptualized to encourage private sector interest in the establishment of the VICS. To carry out this project, a PPP model has been proposed on a finance-designbuild-operate-transfer basis. The Transport Department, in this regard, is seeking bids for establishing the VICS through a fair and transparent comparative bidding process (footnote 45).

The key objectives of the VICS project are to

- establish a state-of-the-art VICS complying with international standards and specifications,

- keep unfit vehicles off the road to improve road safety by reducing road accidents due to mechanical malfunction,

- improve ambient air quality through controlled vehicular emissions,

- reduce costs and property damage due to road-related incidents,

- increase public trust and safety of public transport in Punjab, and

- implement a strict and effective enforcement mechanism to keep unfit vehicles off the road (footnote 45).

The network of stations was expected to utilize the latest inspection technology software and data management systems to test and certify the fitness of the vehicles in Punjab. The automated system meets all international standards. This system was created to get rid of unfit vehicles from the road in order to improve safety and reduce accidents and fatalities due to mechanical malfunction (footnote 45).

\section{Physical Infrastructure}

Under the VICS, the Transport Department intends to develop certification stations. It is the responsibility of the concessionaire to establish the VICS. The concessionaire is expected to establish the following number of vehicle

45 Provincial Government of Punjab, Pakistan; Transport Department. 2014. Request for Proposal for the Establishment of Vehicle Inspection and Certification System in Punjab Pakistan. Lahore. https://www.punjab.gov.pk/system/files/RFP_VICS_PRE-BID_03_01-2014.pdf; and Provincial Government of Punjab, Pakistan; Planning and Development Board, PPP Cell. Project Digest. https://ppp.punjab.gov.pk/digest (accessed 8 September 2020). 
inspection facilities in Punjab Province (footnote 45): Fixed Type A station 11 (Phase I), Fixed Type B station 04 (Phase II), and Type C mobile station 12 (Phase II).

The Transport Department is expected to provide the concessionaire land on lease basis for three sites in Lahore.

The minimum space required for each type of station is as follows: for Type A, 4,180 square meters $\left(\mathrm{m}^{2}\right)$; for Type B, 2,090 $\mathrm{m}^{2}$; and for Type C, $418 \mathrm{~m}^{2}$.

The minimum design standards for the VICS stations and equipment specifications for vehicle testing are specified in the bidding documents.

\section{Description of the Public-Private Partnership}

The Transport Department of the Provincial Government of Punjab aims to establish a state-of-the-art VICS for commercial vehicles in Punjab. The department received an unsolicited proposal from Opus Group Consortium to conduct the project on a PPP mode. The PPP Steering Committee (Planning and Development Department) approved the proposal in 2011 (footnote 45).

The Transport Department, through its technical wing (Transport Planning Unit), prepared the request for proposal and the concession agreement. The department selected a firm based on a comparative bidding process in accordance with the Procurement Law. Prequalification of companies took place in February 2014 and the establishment of the VICS was expected in Spring 2014 (footnote 45).

The proposal was evaluated based on the Punjab Public Private Partnership for Infrastructure Act 2010. The original proponent was given the first right to match the best bid. However, if the proposer who prepared the unsolicited proposal failed to match the best bid, the Transport Department would direct the best bidder to reimburse the cost incurred in project preparation, which was estimated at $\$ 106,840$ (footnote 45 ).

The Provincial Government of Punjab signed an agreement with M/S Opus Inspection (Pvt) Limited to establish 39 VICS stations throughout Punjab Province. The project has the following key features (footnote 45):

- Concession agreement for 20 years;

- Data sharing with excise and taxation, the police, and the district regional transport authority (DRTA);

- Manual and computerized inspections;

- Integrated database management system;

- Vehicle identification through radio-frequency identification (RFID);

- Customer care and management system;

- Auditing and monitoring through a third party; and

- Enforcement through excise and taxation, the DRTA, the traffic police and wardens, and the Transport Department.

The share of the Provincial Government of Punjab is the financial bidding parameter. Bidders are asked to quote the maximum value as a commitment for the provincial government's share on gross annual revenue generated from vehicle inspections. An indicative risk matrix for the project is shown in Table 47. 
Table 47: Risk Matrix for the Vehicle Inspection and Certification System Project

\begin{tabular}{|l|c|c|c|}
\hline Risk Category & Private & Public & Shared \\
\hline Construction & $\checkmark$ & & \\
\hline Design risk & $\checkmark$ & & \\
\hline Financing & $\checkmark$ & & \\
\hline Demand & & & $\checkmark$ \\
\hline User charges & $\checkmark$ & & \\
\hline Land acquisition & & $\checkmark$ & \\
\hline Technology obsolescence & $\checkmark$ & & \\
\hline Social and environmental risks & $\checkmark$ & & \\
\hline Asset handover & & & $\checkmark$ \\
\hline
\end{tabular}

Source: Asian Development Bank.

\section{Project Finance}

The total project cost was estimated at PRs900 million ( $\$ 5.81$ million) at the end of 2019. Project financing details are not available (footnote 45).

\section{Project Construction}

The project construction timelines were clearly defined in the bidding documents along with penalties, in case of delays. The concessionaire was expected to commence the construction work immediately after award of contract and possession of sites in Lahore (Phase I). The completion of construction and commencement of operations for Phase I are scheduled 12 months from the date of site possession. The concessionaire was also responsible for procuring all utilities, including electricity, water, telecommunications, sanitation, and fuel, as required for the completion of the construction works and operation of the VICS station. It was the responsibility of the concessionaire to make alternative power arrangement to meet the schedule and unscheduled load shedding of electricity and gas (footnote 45).

\section{Project Revenues}

The existing fees structure of vehicle inspection and certification was provided as part of the bidding documents. Further, it was indicated that the proposed fee structure could be increased by the concessionaire 1.8 times the existing fee structure for the first year of operation. The fee following the first year will be gradually increased, considering the inflation rate determined by the Pakistan Bureau of Statistics and the State Bank of Pakistan, or 10\% per year, whichever is lower. The commercial operation started in July 2016 (footnote 45).

\section{Key Lessons}

- There should be an appropriate risk transfer such that all key risks are transferred to the private sector player.

- The PPP Act defines ways of handling unsolicited proposals, which establishes the approach for selecting the private sector player in a transparent manner.

- The revenue share model partly allows demand risk sharing by the government, unlike a fixed payment model that would increase the payment burden for the private player. At the same time, the awarding authority (Transport Department) got an upside in the form of higher revenues. Also, it was the responsibility of the government to ensure 50\% compliance rate of the existing Public Service Vehicles Provision of land on lease or rental basis for the VICS stations. 


\section{Appendix 1 \\ Methodology}

\section{Research Period}

The research was carried out in 2020.

\section{List of Indicators}

Table A1.1 through Table A1.6 present a list of indicators for each major topic, including the definition and/or explanation of certain indicators where it is deemed necessary.

Table A1.1: Overview

\begin{tabular}{|c|c|c|c|}
\hline Subcategory & $\begin{array}{l}\text { Supporting } \\
\text { Indicators }\end{array}$ & Units & Definition \\
\hline Overview & None & Description & $\begin{array}{l}\text { - Overview of the PPP legal and regulatory framework } \\
\text { - Number of PPP projects reaching financial close from } 1990 \\
\text { till end of } 2019 \text { across sectors } \\
\text { - Total investment made in PPPs from } 1990 \text { to } 2019 \text { across } \\
\text { - Fectors } \\
\text { - } \text { proatures of past PPP projects including the number of PPPs } \\
\text { - Number of PPP varojects under preparation and } \\
\text { - } \text { procurement } \\
\text { - Paymber of PPP projects supported by the government } \\
\text { - Foreign sponsor participation in PPPs from } 1990 \text { to } 2019 \\
\text { - Major sponsors active in the country's infrastructure sector } \\
\text { - Challenges associated with the PPP landscape in the } \\
\text { country }\end{array}$ \\
\hline
\end{tabular}


Table A1.2: National Public-Private Partnership Landscape

\begin{tabular}{|c|c|c|c|}
\hline Subcategory & Supporting Indicators & Units & Definition \\
\hline \multirow{13}{*}{$\begin{array}{l}\text { National PPP } \\
\text { legal and } \\
\text { regulatory } \\
\text { framework }\end{array}$} & Does the country have- & $\begin{array}{c}\text { Yes/No/Not Applicable/ } \\
\text { Unavailable }\end{array}$ & \multirow{13}{*}{$\begin{array}{l}\text { Details on the legal and } \\
\text { regulatory framework } \\
\text { applicable to PPPs and } \\
\text { its evolution since the } \\
\text { introduction of PPPs in the } \\
\text { country } \\
\text { Details on other supporting } \\
\text { laws and regulations } \\
\text { governing PPPs in the } \\
\text { country }\end{array}$} \\
\hline & - National PPP laws and regulations? & $\begin{array}{c}\text { Yes/No/Not Applicable/ } \\
\text { Unavailable }\end{array}$ & \\
\hline & $\begin{array}{l}\text { - Public financial management laws and } \\
\text { regulations? }\end{array}$ & $\begin{array}{c}\text { Yes/No/Not Applicable/ } \\
\text { Unavailable }\end{array}$ & \\
\hline & - Sector-specific laws and regulations? & $\begin{array}{l}\text { Yes/No/Not Applicable/ } \\
\text { Unavailable }\end{array}$ & \\
\hline & - Procurement laws and regulations? & $\begin{array}{l}\text { Yes/No/Not Applicable/ } \\
\text { Unavailable }\end{array}$ & \\
\hline & - Environmental laws and regulations? & $\begin{array}{l}\text { Yes/No/Not Applicable/ } \\
\text { Unavailable }\end{array}$ & \\
\hline & $\begin{array}{l}\text { - Laws and regulations for social } \\
\text { compliance? }\end{array}$ & $\begin{array}{c}\text { Yes/No/Not Applicable/ } \\
\text { Unavailable }\end{array}$ & \\
\hline & $\begin{array}{l}\text { - Laws and regulations governing land } \\
\text { acquisition and ownership? }\end{array}$ & $\begin{array}{l}\text { Yes/No/Not Applicable/ } \\
\text { Unavailable }\end{array}$ & \\
\hline & - Taxation laws and regulations? & $\begin{array}{c}\text { Yes/No/Not Applicable/ } \\
\text { Unavailable }\end{array}$ & \\
\hline & - Employment laws and regulations? & $\begin{array}{l}\text { Yes/No/Not Applicable/ } \\
\text { Unavailable }\end{array}$ & \\
\hline & - Licensing requirements? & $\begin{array}{l}\text { Yes/No/Not Applicable/ } \\
\text { Unavailable }\end{array}$ & \\
\hline & $\begin{array}{l}\text { Evolution of the PPP legal and regulatory } \\
\text { framework in the country }\end{array}$ & Description & \\
\hline & $\begin{array}{l}\text { What are the other components of the PPP } \\
\text { legal and regulatory framework? }\end{array}$ & Description & \\
\hline PPP types & $\begin{array}{l}\text { Number of PPP types defined in } \\
\text { the PPP regulations }\end{array}$ & Number & $\begin{array}{l}\text { Details on the PPP types } \\
\text { allowed to be used as per } \\
\text { PPP legal and regulatory } \\
\text { framework. In case the } \\
\text { PPP legal and regulatory } \\
\text { framework doesn't specify } \\
\text { the PPP types, this section } \\
\text { provides the details on the } \\
\text { specific PPP types which } \\
\text { have been adopted for } \\
\text { various PPP projects at } \\
\text { various stages of the PPP } \\
\text { life cycle. }\end{array}$ \\
\hline Eligible sectors & - Transportation infrastructure & $\begin{array}{l}\text { Yes/No/Not Applicable/ } \\
\text { Unavailable }\end{array}$ & $\begin{array}{l}\text { Details on various } \\
\text { infrastructure sectors for }\end{array}$ \\
\hline & - Road infrastructure & $\begin{array}{c}\text { Yes/No/Not Applicable/ } \\
\text { Unavailable }\end{array}$ & $\begin{array}{l}\text { which projects could be } \\
\text { procured through the PPP } \\
\text { route as per the PPP legal }\end{array}$ \\
\hline & $\begin{array}{l}\text { - Water resources and irrigation } \\
\text { infrastructure }\end{array}$ & $\begin{array}{c}\text { Yes/No/Not Applicable/ } \\
\text { Unavailable }\end{array}$ & and regulatory framework \\
\hline
\end{tabular}


Table A1. 2 continued

\begin{tabular}{|c|c|c|c|}
\hline Subcategory & Supporting Indicators & Units & Definition \\
\hline & - Water supply infrastructure & $\begin{array}{l}\text { Yes/No/Not Applicable/ } \\
\text { Unavailable }\end{array}$ & \\
\hline & $\begin{array}{l}\text { - Infrastructure for centralized water } \\
\text { waste management systems }\end{array}$ & $\begin{array}{c}\text { Yes/No/Not Applicable/ } \\
\text { Unavailable }\end{array}$ & \\
\hline & $\begin{array}{l}\text { - Infrastructure for local water waste } \\
\text { management system }\end{array}$ & $\begin{array}{l}\text { Yes/No/Not Applicable/ } \\
\text { Unavailable }\end{array}$ & \\
\hline & $\begin{array}{l}\text { - Infrastructure for waste management } \\
\text { system }\end{array}$ & $\begin{array}{l}\text { Yes/No/Not Applicable/ } \\
\text { Unavailable }\end{array}$ & \\
\hline & $\begin{array}{l}\text { - Telecommunication and informatics } \\
\text { infrastructure }\end{array}$ & $\begin{array}{l}\text { Yes/No/Not Applicable/ } \\
\text { Unavailable }\end{array}$ & \\
\hline & $\begin{array}{l}\text { - Energy and electricity infrastructure } \\
\text { including renewable energy }\end{array}$ & $\begin{array}{l}\text { Yes/No/Not Applicable/ } \\
\text { Unavailable }\end{array}$ & \\
\hline & - Energy conservation infrastructure & $\begin{array}{c}\text { Yes/No/Not Applicable/ } \\
\text { Unavailable }\end{array}$ & \\
\hline & - Urban facilities infrastructure & $\begin{array}{l}\text { Yes/No/Not Applicable/ } \\
\text { Unavailable }\end{array}$ & \\
\hline & - Zone infrastructure & $\begin{array}{l}\text { Yes/No/Not Applicable/ } \\
\text { Unavailable }\end{array}$ & \\
\hline & $\begin{array}{l}\text { - Tourism infrastructure (e.g., tourism } \\
\text { information center) }\end{array}$ & $\begin{array}{l}\text { Yes/No/Not Applicable/ } \\
\text { Unavailable }\end{array}$ & \\
\hline & $\begin{array}{l}\text { - Education facilities, research and } \\
\text { development infrastructure }\end{array}$ & $\begin{array}{l}\text { Yes/No/Not Applicable/ } \\
\text { Unavailable }\end{array}$ & \\
\hline & - Health infrastructure & $\begin{array}{l}\text { Yes/No/Not Applicable/ } \\
\text { Unavailable }\end{array}$ & \\
\hline & - Public housing infrastructure & $\begin{array}{l}\text { Yes/No/Not Applicable/ } \\
\text { Unavailable }\end{array}$ & \\
\hline \multirow{6}{*}{$\begin{array}{l}\text { Public-private } \\
\text { partnership } \\
\text { institutional } \\
\text { framework }\end{array}$} & Does the country have a national PPP unit? & $\begin{array}{l}\text { Yes/No/Not Applicable/ } \\
\text { Unavailable }\end{array}$ & \multirow{6}{*}{$\begin{array}{l}\text { Details on the PPP } \\
\text { institutional framework } \\
\text { including availability of } \\
\text { a PPP Unit, functions of } \\
\text { the PPP Unit, principal } \\
\text { public entities associated } \\
\text { with PPPs and their } \\
\text { respective functions, and } \\
\text { details of public entities } \\
\text { responsible for PPP project } \\
\text { identification, appraisal, } \\
\text { approval, oversight, and } \\
\text { monitoring }\end{array}$} \\
\hline & $\begin{array}{l}\text { What are the functions of the national PPP } \\
\text { unit? }\end{array}$ & & \\
\hline & $\begin{array}{l}\text { - Supporting the design and } \\
\text { operationalization of the National PPP } \\
\text { Enabling Framework? }\end{array}$ & $\begin{array}{c}\text { Yes/No/Not Applicable/ } \\
\text { Unavailable }\end{array}$ & \\
\hline & - Helping develop a national PPP pipeline? & $\begin{array}{c}\text { Yes/No/Not Applicable/ } \\
\text { Unavailable }\end{array}$ & \\
\hline & $\begin{array}{l}\text { - Supporting the arrangement of funding } \\
\text { for project preparation (budgetary } \\
\text { allocations, technical assistance } \\
\text { funding from multilateral development } \\
\text { agencies, operating a dedicated project } \\
\text { preparation/project development fund)? }\end{array}$ & $\begin{array}{c}\text { Yes/No/Not Applicable/ } \\
\text { Unavailable }\end{array}$ & \\
\hline & $\begin{array}{l}\text { - Guidance for project preparation to } \\
\text { and coordination with the government } \\
\text { agencies responsible for sponsoring the } \\
\text { projects? }\end{array}$ & $\begin{array}{c}\text { Yes/No/Not Applicable/ } \\
\text { Unavailable }\end{array}$ & \\
\hline
\end{tabular}


Table A1. 2 continued

\begin{tabular}{|c|c|c|c|}
\hline Subcategory & Supporting Indicators & Units & Definition \\
\hline & $\begin{array}{l}\text { - Making recommendations to the PPP } \\
\text { Committee and/or other approving } \\
\text { authorities to provide approvals } \\
\text { associated with various stages of the } \\
\text { PPP process? }\end{array}$ & $\begin{array}{l}\text { Yes/No/Not Applicable/ } \\
\text { Unavailable }\end{array}$ & \\
\hline \multirow{5}{*}{$\begin{array}{l}\text { Entities } \\
\text { responsible for } \\
\text { PPP project } \\
\text { identification, } \\
\text { approval, and } \\
\text { oversight }\end{array}$} & $\begin{array}{l}\text { Who is responsible for identifying, } \\
\text { preparing, and procuring the PPP projects? }\end{array}$ & Description & \\
\hline & $\begin{array}{l}\text { Is there a PPP Committee for providing } \\
\text { approvals at various stages of PPP } \\
\text { projects? }\end{array}$ & $\begin{array}{l}\text { Yes/No/Not Applicable/ } \\
\text { Unavailable }\end{array}$ & \\
\hline & $\begin{array}{l}\text { Who are the approving authorities other } \\
\text { than the PPP Committee for the PPP } \\
\text { projects? }\end{array}$ & & \\
\hline & $\begin{array}{l}\text { Does the country have an independent } \\
\text { think tank for various PPP planning, } \\
\text { budgeting, and policy decisions? }\end{array}$ & $\begin{array}{l}\text { Yes/No/Not Applicable/ } \\
\text { Unavailable }\end{array}$ & \\
\hline & $\begin{array}{l}\text { Is there a legislature for the PPP program } \\
\text { oversight? }\end{array}$ & $\begin{array}{l}\text { Yes/No/Not Applicable/ } \\
\text { Unavailable }\end{array}$ & \\
\hline \multirow{2}{*}{$\begin{array}{l}\text { Entities } \\
\text { responsible for } \\
\text { PPP project } \\
\text { monitoring }\end{array}$} & $\begin{array}{l}\text { Is there an entity for monitoring of PPP } \\
\text { projects post commercial close? }\end{array}$ & $\begin{array}{l}\text { Yes/No/Not Applicable/ } \\
\text { Unavailable }\end{array}$ & \\
\hline & $\begin{array}{l}\text { Is there an entity for monitoring and } \\
\text { management of fiscal risks and liabilities } \\
\text { from PPP projects for the Ministry of } \\
\text { Finance (MOF)? }\end{array}$ & $\begin{array}{l}\text { Yes/No/Not Applicable/ } \\
\text { Unavailable }\end{array}$ & \\
\hline \multirow[t]{9}{*}{$\begin{array}{l}\text { The public- } \\
\text { private } \\
\text { poartnership } \\
\text { process }\end{array}$} & $\begin{array}{l}\text { Does the PPP legal and regulatory } \\
\text { framework provide for a PPP } \\
\text { implementation process covering the } \\
\text { entire PPP life cycle? }\end{array}$ & $\begin{array}{l}\text { Yes/No/Not Applicable/ } \\
\text { Unavailable }\end{array}$ & \multirow{9}{*}{$\begin{array}{l}\text { Details on various stages of } \\
\text { the PPP process including } \\
\text { PPP project identification, } \\
\text { preparation, structuring, } \\
\text { procurement, and } \\
\text { management as per the } \\
\text { PPP legal and regulatory } \\
\text { framework in the country }\end{array}$} \\
\hline & $\begin{array}{l}\text { Does the Feasibility Assessment Stage } \\
\text { cover- }\end{array}$ & $\begin{array}{l}\text { Yes/No/Not Applicable/ } \\
\text { Unavailable }\end{array}$ & \\
\hline & - Technical feasibility? & $\begin{array}{l}\text { Yes/No/Not Applicable/ } \\
\text { Unavailable }\end{array}$ & \\
\hline & - Socioeconomic feasibility? & $\begin{array}{l}\text { Yes/No/Not Applicable/ } \\
\text { Unavailable }\end{array}$ & \\
\hline & - Environmental sustainability? & $\begin{array}{l}\text { Yes/No/Not Applicable/ } \\
\text { Unavailable }\end{array}$ & \\
\hline & - Financial feasibility? & $\begin{array}{l}\text { Yes/No/Not Applicable/ } \\
\text { Unavailable }\end{array}$ & \\
\hline & - Fiscal affordability assessment? & $\begin{array}{l}\text { Yes/No/Not Applicable/ } \\
\text { Unavailable }\end{array}$ & \\
\hline & - Legal assessment? & $\begin{array}{l}\text { Yes/No/Not Applicable/ } \\
\text { Unavailable }\end{array}$ & \\
\hline & $\begin{array}{l}\text { - Risk assessment and PPP project } \\
\text { structuring? }\end{array}$ & $\begin{array}{l}\text { Yes/No/Not Applicable/ } \\
\text { Unavailable }\end{array}$ & \\
\hline
\end{tabular}


Table A1. 2 continued

\begin{tabular}{|c|c|c|c|}
\hline Subcategory & Supporting Indicators & Units & Definition \\
\hline & - Value for Money assessment? & $\begin{array}{c}\text { Yes/No/Not Applicable/ } \\
\text { Unavailable }\end{array}$ & \\
\hline & - Market sounding with stakeholders? & $\begin{array}{l}\text { Yes/No/Not Applicable/ } \\
\text { Unavailable }\end{array}$ & \\
\hline & Is the PPP procurement plan required? & $\begin{array}{c}\text { Yes/No/Not Applicable/ } \\
\text { Unavailable }\end{array}$ & \\
\hline & $\begin{array}{l}\text { Is there a need to set up a separate PPP } \\
\text { procurement committee? }\end{array}$ & $\begin{array}{c}\text { Yes/No/Not Applicable/ } \\
\text { Unavailable }\end{array}$ & \\
\hline & $\begin{array}{l}\text { Is competitive bidding the only method for } \\
\text { selection of PPP private developer? }\end{array}$ & $\begin{array}{c}\text { Yes/No/Not Applicable/ } \\
\text { Unavailable }\end{array}$ & \\
\hline & $\begin{array}{l}\text { Is the prequalification stage necessary? } \\
\text { Or does the PPP legal and regulatory } \\
\text { framework allow flexibility to skip the pre- } \\
\text { qualification stage? }\end{array}$ & $\begin{array}{l}\text { Yes/No/Not Applicable/ } \\
\text { Unavailable }\end{array}$ & \\
\hline & $\begin{array}{l}\text { Does the PPP legal and regulatory process } \\
\text { provide the option to the preferred bidder } \\
\text { for contract negotiations? }\end{array}$ & $\begin{array}{l}\text { Yes/No/Not Applicable/ } \\
\text { Unavailable }\end{array}$ & \\
\hline & $\begin{array}{l}\text { Does the PPP Legal and Regulatory } \\
\text { Framework allow unsuccessful bidders to } \\
\text { challenge the award/ submit complaints? }\end{array}$ & $\begin{array}{l}\text { Yes/No/Not Applicable/ } \\
\text { Unavailable }\end{array}$ & \\
\hline & $\begin{array}{l}\text { What is the maximum time allowed for } \\
\text { submitting a complaint/challenging the } \\
\text { award by unsuccessful bidders from the } \\
\text { announcement of the preferred bidder? }\end{array}$ & $\begin{array}{l}\text { Yes/No/Not Applicable/ } \\
\text { Unavailable }\end{array}$ & \\
\hline & $\begin{array}{l}\text { Does the PPP legal and regulatory } \\
\text { framework provide for transparency? }\end{array}$ & $\begin{array}{l}\text { Yes/No/Not Applicable/ } \\
\text { Unavailable }\end{array}$ & \\
\hline & $\begin{array}{l}\text { Which of the following are required to be } \\
\text { published? }\end{array}$ & $\begin{array}{l}\text { Yes/No/Not Applicable/ } \\
\text { Unavailable }\end{array}$ & \\
\hline & $\begin{array}{l}\text { - Findings from the feasibility } \\
\text { assessment? }\end{array}$ & $\begin{array}{l}\text { Yes/No/Not Applicable/ } \\
\text { Unavailable }\end{array}$ & \\
\hline & - Procurement notice? & $\begin{array}{c}\text { Yes/No/Not Applicable/ } \\
\text { Unavailable }\end{array}$ & \\
\hline & $\begin{array}{l}\text { - Outcome of stakeholder consultations } \\
\text { from market sounding? }\end{array}$ & $\begin{array}{c}\text { Yes/No/Not Applicable/ } \\
\text { Unavailable }\end{array}$ & \\
\hline & $\begin{array}{l}\text { - Clarifications to prequalification } \\
\text { queries? }\end{array}$ & $\begin{array}{l}\text { Yes/No/Not Applicable/ } \\
\text { Unavailable }\end{array}$ & \\
\hline & - Prequalification results? & $\begin{array}{l}\text { Yes/No/Not Applicable/ } \\
\text { Unavailable }\end{array}$ & \\
\hline & - Clarifications to pre-bid queries? & $\begin{array}{c}\text { Yes/No/Not Applicable/ } \\
\text { Unavailable }\end{array}$ & \\
\hline & $\begin{array}{l}\text { - Results for the bid stage and selection } \\
\text { of preferred bidder? }\end{array}$ & $\begin{array}{c}\text { Yes/No/Not Applicable/ } \\
\text { Unavailable }\end{array}$ & \\
\hline
\end{tabular}


Table A1. 2 continued

\begin{tabular}{|c|c|c|c|}
\hline Subcategory & Supporting Indicators & Units & Definition \\
\hline & $\begin{array}{l}\text { - Final concession agreement to be } \\
\text { entered between the government } \\
\text { agency and the preferred bidder? And } \\
\text { other PPP project agreements executed } \\
\text { between government agency and } \\
\text { preferred bidder? }\end{array}$ & $\begin{array}{l}\text { Yes/No/Not Applicable/ } \\
\text { Unavailable }\end{array}$ & \\
\hline & - Confidentiality & $\begin{array}{l}\text { Yes/No/Not Applicable/ } \\
\text { Unavailable }\end{array}$ & \\
\hline \multirow{16}{*}{$\begin{array}{l}\text { PPP standard } \\
\text { operating } \\
\text { procedures, tool } \\
\text { kits, templates, } \\
\text { and model bid } \\
\text { documents }\end{array}$} & $\begin{array}{l}\text { Does the country have PPP Guidelines/ } \\
\text { PPP Guidance Manual? }\end{array}$ & $\begin{array}{l}\text { Yes/No/Not Applicable/ } \\
\text { Unavailable }\end{array}$ & \multirow{16}{*}{$\begin{array}{l}\text { Details on standard } \\
\text { operating procedures and } \\
\text { standard templates or } \\
\text { model bidding documents } \\
\text { available for PPPs, if any. } \\
\\
\text { Details on the key clauses } \\
\text { in a PPP Agreement based } \\
\text { on the review of select } \\
\text { PPP Agreements already } \\
\text { executed, and/or the } \\
\text { review of the PPP legal and } \\
\text { regulatory framework }\end{array}$} \\
\hline & $\begin{array}{l}\text { Does the PPP Guidelines/PPP Guidance } \\
\text { Manual adequately cover the process, } \\
\text { entities involved, roles and responsibilities } \\
\text { of various entities, approvals required at } \\
\text { various stages, and the timelines for the } \\
\text { various stages of the PPP project life cycle? }\end{array}$ & $\begin{array}{l}\text { Yes/No/Not Applicable/ } \\
\text { Unavailable }\end{array}$ & \\
\hline & $\begin{array}{l}\text { What are the templates and checklists } \\
\text { available in the PPP Guidelines/PPP } \\
\text { Guidance Manual? }\end{array}$ & $\begin{array}{l}\text { Yes/No/Not Applicable/ } \\
\text { Unavailable }\end{array}$ & \\
\hline & $\begin{array}{l}\text { - Project Needs Assessment and Options } \\
\text { Analysis checklist? }\end{array}$ & $\begin{array}{l}\text { Yes/No/Not Applicable/ } \\
\text { Unavailable }\end{array}$ & \\
\hline & - Project Due Diligence checklist? & $\begin{array}{l}\text { Yes/No/Not Applicable/ } \\
\text { Unavailable }\end{array}$ & \\
\hline & - Technical Assessment checklist? & $\begin{array}{c}\text { Yes/No/Not Applicable/ } \\
\text { Unavailable }\end{array}$ & \\
\hline & - Environmental Assessment checklist? & $\begin{array}{l}\text { Yes/No/Not Applicable/ } \\
\text { Unavailable }\end{array}$ & \\
\hline & - PPP Procurement Plan template? & $\begin{array}{l}\text { Yes/No/Not Applicable/ } \\
\text { Unavailable }\end{array}$ & \\
\hline & $\begin{array}{l}\text { Does the country have standardized/ } \\
\text { model bidding documents for PPPs? }\end{array}$ & $\begin{array}{l}\text { Yes/No/Not Applicable/ } \\
\text { Unavailable }\end{array}$ & \\
\hline & $\begin{array}{l}\text { - Model Request for Qualification (RFQ) } \\
\text { document? }\end{array}$ & $\begin{array}{l}\text { Yes/No/Not Applicable/ } \\
\text { Unavailable }\end{array}$ & \\
\hline & $\begin{array}{l}\text { - Model Request for Proposal (RFP) } \\
\text { document? }\end{array}$ & $\begin{array}{l}\text { Yes/No/Not Applicable/ } \\
\text { Unavailable }\end{array}$ & \\
\hline & - Model PPP/Concession Agreement? & $\begin{array}{l}\text { Yes/No/Not Applicable/ } \\
\text { Unavailable }\end{array}$ & \\
\hline & - State Support Agreement? & $\begin{array}{c}\text { Yes/No/Not Applicable/ } \\
\text { Unavailable }\end{array}$ & \\
\hline & - VGF Agreement? & $\begin{array}{l}\text { Yes/No/Not Applicable/ } \\
\text { Unavailable }\end{array}$ & \\
\hline & - Guarantee Agreement? & $\begin{array}{l}\text { Yes/No/Not Applicable/ } \\
\text { Unavailable }\end{array}$ & \\
\hline & - Power Purchase Agreement? & $\begin{array}{c}\text { Yes/No/Not Applicable/ } \\
\text { Unavailable }\end{array}$ & \\
\hline
\end{tabular}


Table A1. 2 continued

\begin{tabular}{|c|c|c|c|}
\hline Subcategory & Supporting Indicators & Units & Definition \\
\hline & - Capacity Take-or-Pay Contract? & $\begin{array}{c}\text { Yes/No/Not Applicable/ } \\
\text { Unavailable }\end{array}$ & \\
\hline & - Fuel Supply Agreement? & $\begin{array}{l}\text { Yes/No/Not Applicable/ } \\
\text { Unavailable }\end{array}$ & \\
\hline & $\begin{array}{l}\text { - Transmission and Use of System } \\
\text { Agreement? }\end{array}$ & $\begin{array}{c}\text { Yes/No/Not Applicable/ } \\
\text { Unavailable }\end{array}$ & \\
\hline & $\begin{array}{l}\text { - Performance-based Operations and } \\
\text { Maintenance Contract? }\end{array}$ & $\begin{array}{l}\text { Yes/No/Not Applicable/ } \\
\text { Unavailable }\end{array}$ & \\
\hline & $\begin{array}{l}\text { - Engineering, Procurement and } \\
\text { Construction Contract? }\end{array}$ & $\begin{array}{l}\text { Yes/No/Not Applicable/ } \\
\text { Unavailable }\end{array}$ & \\
\hline & $\begin{array}{l}\text { Does the country have standardized PPP } \\
\text { agreement terms? }\end{array}$ & $\begin{array}{l}\text { Yes/No/Not Applicable/ } \\
\text { Unavailable }\end{array}$ & \\
\hline & - PPP Family Indicator? & $\begin{array}{c}\text { Yes/No/Not Applicable/ } \\
\text { Unavailable }\end{array}$ & \\
\hline & - PPP Mode Validity Indicator? & $\begin{array}{l}\text { Yes/No/Not Applicable/ } \\
\text { Unavailable }\end{array}$ & \\
\hline & - PPP Suitability Filter? & $\begin{array}{l}\text { Yes/No/Not Applicable/ } \\
\text { Unavailable }\end{array}$ & \\
\hline & - PPP Screening Tool? & $\begin{array}{l}\text { Yes/No/Not Applicable/ } \\
\text { Unavailable }\end{array}$ & \\
\hline & - Financial Viability Indicator Model? & $\begin{array}{l}\text { Yes/No/Not Applicable/ } \\
\text { Unavailable }\end{array}$ & \\
\hline & - Economic Viability Indicator Model? & $\begin{array}{c}\text { Yes/No/Not Applicable/ } \\
\text { Unavailable }\end{array}$ & \\
\hline & - VFM Indicator Tool? & $\begin{array}{c}\text { Yes/No/Not Applicable/ } \\
\text { Unavailable }\end{array}$ & \\
\hline & - Readiness Filter? & $\begin{array}{c}\text { Yes/No/Not Applicable/ } \\
\text { Unavailable }\end{array}$ & \\
\hline & $\begin{array}{l}\text { Is there a framework for monitoring fiscal } \\
\text { risks from PPPs including the following? }\end{array}$ & $\begin{array}{l}\text { Yes/No/Not Applicable/ } \\
\text { Unavailable }\end{array}$ & \\
\hline & $\begin{array}{l}\text { - Process for assessing fiscal } \\
\text { commitments? }\end{array}$ & $\begin{array}{c}\text { Yes/No/Not Applicable/ } \\
\text { Unavailable }\end{array}$ & \\
\hline & $\begin{array}{l}\text { - Process for approving fiscal } \\
\text { commitments? }\end{array}$ & $\begin{array}{c}\text { Yes/No/Not Applicable/ } \\
\text { Unavailable }\end{array}$ & \\
\hline & $\begin{array}{l}\text { - Process for monitoring fiscal } \\
\text { commitments? }\end{array}$ & $\begin{array}{c}\text { Yes/No/Not Applicable/ } \\
\text { Unavailable }\end{array}$ & \\
\hline & $\begin{array}{l}\text { - Process for reporting fiscal } \\
\text { commitments? }\end{array}$ & $\begin{array}{c}\text { Yes/No/Not Applicable/ } \\
\text { Unavailable }\end{array}$ & \\
\hline & $\begin{array}{l}\text { - Process for budgeting fiscal } \\
\text { commitments? }\end{array}$ & $\begin{array}{c}\text { Yes/No/Not Applicable/ } \\
\text { Unavailable }\end{array}$ & \\
\hline & $\begin{array}{l}\text { Are there fiscal prudence norms/thresholds } \\
\text { to limit fiscal exposure to PPPs? }\end{array}$ & $\begin{array}{c}\text { Yes/No/Not Applicable/ } \\
\text { Unavailable }\end{array}$ & \\
\hline & $\begin{array}{l}\text { Is there a process for assessing and } \\
\text { budgeting contingent liabilities from PPPs? }\end{array}$ & $\begin{array}{c}\text { Yes/No/Not Applicable/ } \\
\text { Unavailable }\end{array}$ & \\
\hline
\end{tabular}


Table A1. 2 continued

\begin{tabular}{|c|c|c|c|}
\hline Subcategory & Supporting Indicators & Units & Definition \\
\hline \multirow[t]{7}{*}{$\begin{array}{l}\text { Lender's } \\
\text { security rights }\end{array}$} & $\begin{array}{l}\text { Does the law specifically enable lenders } \\
\text { the following rights: }\end{array}$ & $\begin{array}{l}\text { Yes/No/Not Applicable/ } \\
\text { Unavailable }\end{array}$ & \multirow{7}{*}{$\begin{array}{l}\text { The rights of lenders } \\
\text { including the charge of } \\
\text { project assets }\end{array}$} \\
\hline & - Security over the project assets & $\begin{array}{l}\text { Yes/No/Not Applicable/ } \\
\text { Unavailable }\end{array}$ & \\
\hline & $\begin{array}{l}\text { - Security over the land on which they are } \\
\text { built (land use right) }\end{array}$ & $\begin{array}{l}\text { Yes/No/Not Applicable/ } \\
\text { Unavailable }\end{array}$ & \\
\hline & $\begin{array}{l}\text { - Security over the shares of a PPP project } \\
\text { company }\end{array}$ & $\begin{array}{l}\text { Yes/No/Not Applicable/ } \\
\text { Unavailable }\end{array}$ & \\
\hline & $\begin{array}{l}\text { - Can there be a direct agreement } \\
\text { between the government and lenders? }\end{array}$ & $\begin{array}{l}\text { Yes/No/Not Applicable/ } \\
\text { Unavailable }\end{array}$ & \\
\hline & $\begin{array}{l}\text { - Do lenders get priority in the case of } \\
\text { insolvency? }\end{array}$ & $\begin{array}{l}\text { Yes/No/Not Applicable/ } \\
\text { Unavailable }\end{array}$ & \\
\hline & - Can lenders be given step-in rights? & $\begin{array}{c}\text { Yes/No/Not Applicable/ } \\
\text { Unavailable }\end{array}$ & \\
\hline \multirow[t]{9}{*}{$\begin{array}{l}\text { Termination } \\
\text { and } \\
\text { compensation }\end{array}$} & $\begin{array}{l}\text { Does the law specifically enable } \\
\text { compensation payment to the private } \\
\text { partner in case of early termination due to: }\end{array}$ & & \multirow{9}{*}{$\begin{array}{l}\text { Definition on whether the } \\
\text { private player is eligible for } \\
\text { compensation in case of } \\
\text { PPP project termination } \\
\text { due to various reasons }\end{array}$} \\
\hline & $\begin{array}{l}\text { - Public sector default or termination for } \\
\text { reasons of public interest }\end{array}$ & $\begin{array}{l}\text { Yes/No/Not Applicable/ } \\
\text { Unavailable }\end{array}$ & \\
\hline & - Private sector default & $\begin{array}{l}\text { Yes/No/Not Applicable/ } \\
\text { Unavailable }\end{array}$ & \\
\hline & - Force majeure & $\begin{array}{l}\text { Yes/No/Not Applicable/ } \\
\text { Unavailable }\end{array}$ & \\
\hline & $\begin{array}{l}\text { - Does the law enable the concept of } \\
\text { economic/financial equilibrium? }\end{array}$ & $\begin{array}{l}\text { Yes/No/Not Applicable/ } \\
\text { Unavailable }\end{array}$ & \\
\hline & $\begin{array}{l}\text { Does the law enable compensation } \\
\text { payment to the private partner due to: }\end{array}$ & $\begin{array}{l}\text { Yes/No/Not Applicable/ } \\
\text { Unavailable }\end{array}$ & \\
\hline & - Material adverse government action & $\begin{array}{l}\text { Yes/No/Not Applicable/ } \\
\text { Unavailable }\end{array}$ & \\
\hline & - Force majeure & $\begin{array}{l}\text { Yes/No/Not Applicable/ } \\
\text { Unavailable }\end{array}$ & \\
\hline & - Change in law & $\begin{array}{c}\text { Yes/No/Not Applicable/ } \\
\text { Unavailable }\end{array}$ & \\
\hline \multirow[t]{5}{*}{$\begin{array}{l}\text { Unsolicited PPP } \\
\text { proposals }\end{array}$} & $\begin{array}{l}\text { Does the PPP legal and regulatory } \\
\text { framework allow submission and } \\
\text { acceptance of unsolicited proposals? }\end{array}$ & $\begin{array}{l}\text { Yes/No/Not Applicable/ } \\
\text { Unavailable }\end{array}$ & \multirow{5}{*}{$\begin{array}{l}\text { Details on possibility of } \\
\text { submission of unsolicited } \\
\text { PPP proposals, and their } \\
\text { treatment including, } \\
\text { potential advantages } \\
\text { provided to the unsolicited } \\
\text { PPP proposal proponent at } \\
\text { the PPP procurement stage }\end{array}$} \\
\hline & $\begin{array}{l}\text { What are the advantages provided to the } \\
\text { project proponent for an unsolicited bid? }\end{array}$ & & \\
\hline & $\begin{array}{l}\text { - Competitive advantage at bid } \\
\text { evaluation? }\end{array}$ & $\begin{array}{l}\text { Yes/No/Not Applicable/ } \\
\text { Unavailable }\end{array}$ & \\
\hline & - Swiss Challenge? & $\begin{array}{l}\text { Yes/No/Not Applicable/ } \\
\text { Unavailable }\end{array}$ & \\
\hline & $\begin{array}{l}\text { - Compensation of the project } \\
\text { development costs? }\end{array}$ & $\begin{array}{l}\text { Yes/No/Not Applicable/ } \\
\text { Unavailable }\end{array}$ & \\
\hline
\end{tabular}


Table A1. 2 continued

\begin{tabular}{|c|c|c|c|}
\hline \multirow[t]{3}{*}{ Subcategory } & \multicolumn{2}{|l|}{ Supporting Indicators } & \multirow[t]{3}{*}{ Definition } \\
\hline & $\begin{array}{l}\text { - Government support for land } \\
\text { acquisition and resettlement cost? }\end{array}$ & $\begin{array}{l}\text { Yes/No/Not Applicable/ } \\
\text { Unavailable }\end{array}$ & \\
\hline & $\begin{array}{l}\text { Government support in the form of } \\
\text { viability gap fund and guarantees? }\end{array}$ & $\begin{array}{l}\text { Yes/No/Not Applicable/ } \\
\text { Unavailable }\end{array}$ & \\
\hline \multirow{3}{*}{$\begin{array}{l}\text { Foreign investor } \\
\text { participation } \\
\text { restrictions }\end{array}$} & $\begin{array}{l}\text { Is there any restriction for foreign investors } \\
\text { on: }\end{array}$ & & \multirow{3}{*}{$\begin{array}{l}\text { Definition of whether } \\
\text { there are any statutory } \\
\text { restrictions on foreign } \\
\text { equity investments and } \\
\text { ownership in PPP projects }\end{array}$} \\
\hline & $\begin{array}{l}\text { - Land use/ownership rights as opposed } \\
\text { to similar rights of local investors }\end{array}$ & $\begin{array}{l}\text { Yes/No/Not Applicable/ } \\
\text { Unavailable }\end{array}$ & \\
\hline & - Currency conversion & $\begin{array}{l}\text { Yes/No/Not Applicable/ } \\
\text { Unavailable }\end{array}$ & \\
\hline \multirow[t]{8}{*}{$\begin{array}{l}\text { Dispute } \\
\text { resolution }\end{array}$} & $\begin{array}{l}\text { Does the country have a dispute resolution } \\
\text { tribunal (DRT)? }\end{array}$ & $\begin{array}{l}\text { Yes/No/Not Applicable/ } \\
\text { Unavailable }\end{array}$ & \multirow{8}{*}{$\begin{array}{l}\text { Definition of the dispute } \\
\text { resolution process and } \\
\text { mechanisms available in the } \\
\text { country }\end{array}$} \\
\hline & $\begin{array}{l}\text { Does the country have an institutional } \\
\text { arbitration mechanism? }\end{array}$ & $\begin{array}{l}\text { Yes/No/Not Applicable/ } \\
\text { Unavailable }\end{array}$ & \\
\hline & $\begin{array}{l}\text { Can a foreign law be chosen to govern PPP } \\
\text { contracts? }\end{array}$ & $\begin{array}{l}\text { Yes/No/Not Applicable/ } \\
\text { Unavailable }\end{array}$ & \\
\hline & $\begin{array}{l}\text { What dispute resolution mechanisms are } \\
\text { available for PPP agreements? }\end{array}$ & & \\
\hline & - Court litigation & $\begin{array}{l}\text { Yes/No/Not Applicable/ } \\
\text { Unavailable }\end{array}$ & \\
\hline & - Local arbitration & $\begin{array}{l}\text { Yes/No/Not Applicable/ } \\
\text { Unavailable }\end{array}$ & \\
\hline & - International arbitration & $\begin{array}{l}\text { Yes/No/Not Applicable/ } \\
\text { Unavailable }\end{array}$ & \\
\hline & $\begin{array}{l}\text { Has the country signed the New York } \\
\text { Convention on the Recognition and } \\
\text { Enforcement of Foreign Arbitral Awards? }\end{array}$ & $\begin{array}{l}\text { Yes/No/Not Applicable/ } \\
\text { Unavailable }\end{array}$ & \\
\hline \multirow[t]{2}{*}{$\begin{array}{l}\text { Environmental } \\
\text { and social issues }\end{array}$} & $\begin{array}{l}\text { Is there a local regulation establishing } \\
\text { a process for environmental impact } \\
\text { assessment? }\end{array}$ & $\begin{array}{l}\text { Yes/No/Not Applicable/ } \\
\text { Unavailable }\end{array}$ & $\begin{array}{l}\text { Details on whether the legal } \\
\text { and regulatory framework } \\
\text { governing PPPs stipulates } \\
\text { a mechanism for managing } \\
\text { the environmental impact } \\
\text { of a PPP project, including } \\
\text { the potential environmental } \\
\text { issues which could be } \\
\text { caused by a PPP project }\end{array}$ \\
\hline & $\begin{array}{l}\text { Is there a legal mechanism for the private } \\
\text { partner to limit environmental liability for } \\
\text { what is outside of its control or caused by } \\
\text { third parties? }\end{array}$ & $\begin{array}{c}\text { Yes/No/Not Applicable/ } \\
\text { Unavailable }\end{array}$ & $\begin{array}{l}\text { Deliberation on whether } \\
\text { a private partner can } \\
\text { limit the circumstances } \\
\text { where it is penalized for } \\
\text { breaching environmental } \\
\text { standards where such a } \\
\text { breach is not within its } \\
\text { control. For example, a } \\
\text { wastewater treatment plant } \\
\text { operator will wish to avoid } \\
\text { prosecution or even liability }\end{array}$ \\
\hline
\end{tabular}


Table A1. 2 continued

\begin{tabular}{|c|c|c|c|}
\hline Subcategory & Supporting Indicators & Units & Definition \\
\hline & & & $\begin{array}{l}\text { for pollution caused by a } \\
\text { pollutant in the influent } \\
\text { which the treatment plant } \\
\text { cannot treat, or will at least } \\
\text { want to have the power to } \\
\text { pursue the polluter to stop } \\
\text { the pollution and/or obtain } \\
\text { compensation. }\end{array}$ \\
\hline & $\begin{array}{l}\text { Is there a local regulation establishing a } \\
\text { process for social impact assessment? }\end{array}$ & $\begin{array}{l}\text { Yes/No/Not Applicable/ } \\
\text { Unavailable }\end{array}$ & $\begin{array}{l}\text { Details on whether the legal } \\
\text { and regulatory framework } \\
\text { governing PPPs stipulates a } \\
\text { mechanism for managing the } \\
\text { social impact of a PPP project, } \\
\text { including the potential social } \\
\text { issues which could be caused } \\
\text { by a PPP project }\end{array}$ \\
\hline & $\begin{array}{l}\text { Is there involuntary land clearance for PPP } \\
\text { projects? }\end{array}$ & $\begin{array}{l}\text { Yes/No/Not Applicable/ } \\
\text { Unavailable }\end{array}$ & $\begin{array}{l}\text { Deliberation on whether } \\
\text { land expropriation is } \\
\text { possible for PPP projects }\end{array}$ \\
\hline \multirow[t]{13}{*}{ Land rights } & $\begin{array}{l}\text { Which of the following is permitted to the } \\
\text { private partner: }\end{array}$ & & \multirow{13}{*}{$\begin{array}{l}\text { Definition of various } \\
\text { mechanisms through which } \\
\text { landownership and/or land } \\
\text { use rights could be provided } \\
\text { to the private partner in } \\
\text { respect of the project site } \\
\text { for a PPP project } \\
\text { Details on land records and } \\
\text { registration which could } \\
\text { be provided to the private } \\
\text { partner }\end{array}$} \\
\hline & $\begin{array}{l}\text { - Transfer land lease/use/ownership rights } \\
\text { to third party }\end{array}$ & $\begin{array}{l}\text { Yes/No/Not Applicable/ } \\
\text { Unavailable }\end{array}$ & \\
\hline & - Use leased/owned land as collateral & $\begin{array}{l}\text { Yes/No/Not Applicable/ } \\
\text { Unavailable }\end{array}$ & \\
\hline & - Mortgage leased/owned land & $\begin{array}{l}\text { Yes/No/Not Applicable/ } \\
\text { Unavailable }\end{array}$ & \\
\hline & $\begin{array}{l}\text { Is there a legal mechanism for granting } \\
\text { wayleave rights, for example, laying water } \\
\text { pipes or fibre cables over land occupied by } \\
\text { persons other than the government or the } \\
\text { private partner? }\end{array}$ & $\begin{array}{l}\text { Yes/No/Not Applicable/ } \\
\text { Unavailable }\end{array}$ & \\
\hline & $\begin{array}{l}\text { Is there a land registry/cadastre with public } \\
\text { information on land plots? }\end{array}$ & $\begin{array}{l}\text { Yes/No/Not Applicable/ } \\
\text { Unavailable }\end{array}$ & \\
\hline & $\begin{array}{l}\text { Which of the following information on land } \\
\text { plots is available to the private partner: }\end{array}$ & $\begin{array}{l}\text { Yes/No/Not Applicable/ } \\
\text { Unavailable }\end{array}$ & \\
\hline & - Appraisal of land value & $\begin{array}{l}\text { Yes/No/Not Applicable/ } \\
\text { Unavailable }\end{array}$ & \\
\hline & - Landowners & $\begin{array}{l}\text { Yes/No/Not Applicable/ } \\
\text { Unavailable }\end{array}$ & \\
\hline & - Land boundaries & $\begin{array}{l}\text { Yes/No/Not Applicable/ } \\
\text { Unavailable }\end{array}$ & \\
\hline & - Utility connections & $\begin{array}{l}\text { Yes/No/Not Applicable/ } \\
\text { Unavailable }\end{array}$ & \\
\hline & - Immovable property on land & $\begin{array}{l}\text { Yes/No/Not Applicable/ } \\
\text { Unavailable }\end{array}$ & \\
\hline & - Plots classification & $\begin{array}{l}\text { Yes/No/Not Applicable/ } \\
\text { Unavailable }\end{array}$ & \\
\hline
\end{tabular}


Table A1. 2 continued

\begin{tabular}{|c|c|c|c|}
\hline Subcategory & Supporting Indicators & Units & Definition \\
\hline \multirow{19}{*}{$\begin{array}{l}\text { Government } \\
\text { financial } \\
\text { support for PPP } \\
\text { projects }\end{array}$} & $\begin{array}{l}\text { Is there a dedicated government financial } \\
\text { support mechanism for PPP projects? }\end{array}$ & $\begin{array}{l}\text { Yes/No/Not Applicable/ } \\
\text { Unavailable }\end{array}$ & \multirow{19}{*}{$\begin{array}{l}\text { Details on various } \\
\text { mechanisms of government } \\
\text { financial support available } \\
\text { to make PPP projects } \\
\text { financially viable } \\
\text { Salient features of } \\
\text { government financial } \\
\text { support mechanisms } \\
\text { available }\end{array}$} \\
\hline & $\begin{array}{l}\text { What are the instruments of government } \\
\text { financial support available under this } \\
\text { government financial support mechanism? }\end{array}$ & & \\
\hline & - Capital grant & $\begin{array}{l}\text { Yes/No/Not Applicable/ } \\
\text { Unavailable }\end{array}$ & \\
\hline & - Operations grant & $\begin{array}{c}\text { Yes/No/Not Applicable/ } \\
\text { Unavailable }\end{array}$ & \\
\hline & - Annuity/availability payments & $\begin{array}{l}\text { Yes/No/Not Applicable/ } \\
\text { Unavailable }\end{array}$ & \\
\hline & - Guarantees to cover & $\begin{array}{l}\text { Yes/No/Not Applicable/ } \\
\text { Unavailable }\end{array}$ & \\
\hline & $\begin{array}{l}\text { - Currency inconvertibility and } \\
\text { transfer risk }\end{array}$ & $\begin{array}{l}\text { Yes/No/Not Applicable/ } \\
\text { Unavailable }\end{array}$ & \\
\hline & - Foreign exchange risk & $\begin{array}{c}\text { Yes/No/Not Applicable/ } \\
\text { Unavailable }\end{array}$ & \\
\hline & - War and civil disturbance risk & $\begin{array}{l}\text { Yes/No/Not Applicable/ } \\
\text { Unavailable }\end{array}$ & \\
\hline & - Breach of contract risk & $\begin{array}{c}\text { Yes/No/Not Applicable/ } \\
\text { Unavailable }\end{array}$ & \\
\hline & - Regulatory risk & $\begin{array}{c}\text { Yes/No/Not Applicable/ } \\
\text { Unavailable }\end{array}$ & \\
\hline & - Expropriation risk & $\begin{array}{c}\text { Yes/No/Not Applicable/ } \\
\text { Unavailable }\end{array}$ & \\
\hline & - Government payment obligation risk & $\begin{array}{l}\text { Yes/No/Not Applicable/ } \\
\text { Unavailable }\end{array}$ & \\
\hline & - Credit risk & $\begin{array}{l}\text { Yes/No/Not Applicable/ } \\
\text { Unavailable }\end{array}$ & \\
\hline & - Minimum demand/revenue risk & $\begin{array}{c}\text { Yes/No/Not Applicable/ } \\
\text { Unavailable }\end{array}$ & \\
\hline & $\begin{array}{l}\text { - Risk of making annuity/availability } \\
\text { payments in a timely manner }\end{array}$ & $\begin{array}{c}\text { Yes/No/Not Applicable/ } \\
\text { Unavailable }\end{array}$ & \\
\hline & $\begin{array}{l}\text { What are the caps/ceilings for the } \\
\text { government financial support under each } \\
\text { of the abovementioned government } \\
\text { financial support instruments? }\end{array}$ & & \\
\hline & $\begin{array}{l}\text { Is there a minimum PPP project size } \\
\text { (investment) for a PPP project to be eligible } \\
\text { for receiving government financial support? }\end{array}$ & $\begin{array}{l}\text { Yes/No/Not Applicable/ } \\
\text { Unavailable }\end{array}$ & \\
\hline & $\begin{array}{l}\text { Are there minimum financial commitment } \\
\text { requirements for the private developer } \\
\text { equity before the government support } \\
\text { could be drawn? }\end{array}$ & $\begin{array}{l}\text { Yes/No/Not Applicable/ } \\
\text { Unavailable }\end{array}$ & \\
\hline
\end{tabular}


Table A1.2 continued

\begin{tabular}{|c|c|c|c|}
\hline Subcategory & Supporting Indicators & Units & Definition \\
\hline & $\begin{array}{l}\text { Is the government financial support } \\
\text { required, and an allowed bid parameter for } \\
\text { PPP projects? }\end{array}$ & $\begin{array}{l}\text { Yes/No/Not Applicable/ } \\
\text { Unavailable }\end{array}$ & \\
\hline & $\begin{array}{l}\text { Are unsolicited PPP proposals eligible to } \\
\text { receive government financial support? }\end{array}$ & $\begin{array}{l}\text { Yes/No/Not Applicable/ } \\
\text { Unavailable }\end{array}$ & \\
\hline & $\begin{array}{l}\text { Are there standard operating procedures } \\
\text { for providing government financial support } \\
\text { to PPP projects? }\end{array}$ & $\begin{array}{l}\text { Yes/No/Not Applicable/ } \\
\text { Unavailable }\end{array}$ & \\
\hline & - Appraisal and approval process & $\begin{array}{l}\text { Yes/No/Not Applicable/ } \\
\text { Unavailable }\end{array}$ & \\
\hline & - Budgeting process & $\begin{array}{l}\text { Yes/No/Not Applicable/ } \\
\text { Unavailable }\end{array}$ & \\
\hline & - Disbursement process & $\begin{array}{c}\text { Yes/No/Not Applicable/ } \\
\text { Unavailable }\end{array}$ & \\
\hline & - Monitoring process & $\begin{array}{l}\text { Yes/No/Not Applicable/ } \\
\text { Unavailable }\end{array}$ & \\
\hline & $\begin{array}{l}\text { - Accounting, auditing, and reporting } \\
\text { process }\end{array}$ & $\begin{array}{c}\text { Yes/No/Not Applicable/ } \\
\text { Unavailable }\end{array}$ & \\
\hline & $\begin{array}{l}\text { Who are the signatories to the Government } \\
\text { Financial Support Agreement? }\end{array}$ & & \\
\hline & $\begin{array}{l}\text { Who is responsible for monitoring the } \\
\text { performance of PPP projects availing } \\
\text { government financial support? }\end{array}$ & $\begin{array}{l}\text { Yes/No/Not Applicable/ } \\
\text { Unavailable }\end{array}$ & \\
\hline & - Independent engineer? & $\begin{array}{c}\text { Yes/No/Not Applicable/ } \\
\text { Unavailable }\end{array}$ & \\
\hline & - Government agency? & $\begin{array}{l}\text { Yes/No/Not Applicable/ } \\
\text { Unavailable }\end{array}$ & \\
\hline & - Ministry of Finance? & $\begin{array}{c}\text { Yes/No/Not Applicable/ } \\
\text { Unavailable }\end{array}$ & \\
\hline & $\begin{array}{l}\text { What are the other forms of government } \\
\text { support available for PPP projects? }\end{array}$ & $\begin{array}{l}\text { Yes/No/Not Applicable/ } \\
\text { Unavailable }\end{array}$ & \\
\hline & - Land acquisition funding support? & $\begin{array}{c}\text { Yes/No/Not Applicable/ } \\
\text { Unavailable }\end{array}$ & \\
\hline & $\begin{array}{l}\text { - Funding support for resettlement and } \\
\text { rehabilitation of affected parties? }\end{array}$ & $\begin{array}{c}\text { Yes/No/Not Applicable/ } \\
\text { Unavailable }\end{array}$ & \\
\hline & - Tax holidays/exemptions? & $\begin{array}{c}\text { Yes/No/Not Applicable/ } \\
\text { Unavailable }\end{array}$ & \\
\hline & - Real estate development rights? & $\begin{array}{l}\text { Yes/No/Not Applicable/ } \\
\text { Unavailable }\end{array}$ & \\
\hline & - Advertising and marketing rights? & $\begin{array}{c}\text { Yes/No/Not Applicable/ } \\
\text { Unavailable }\end{array}$ & \\
\hline & - Interest rate/cost of debt subventions? & $\begin{array}{c}\text { Yes/No/Not Applicable/ } \\
\text { Unavailable }\end{array}$ & \\
\hline & - Other subsidies and subventions? & $\begin{array}{c}\text { Yes/No/Not Applicable/ } \\
\text { Unavailable }\end{array}$ & \\
\hline
\end{tabular}


Table A1. 2 continued

\begin{tabular}{|c|c|c|c|}
\hline \multirow[t]{2}{*}{ Subcategory } & \multicolumn{2}{|l|}{ Supporting Indicators } & \multirow[t]{2}{*}{ Definition } \\
\hline & $\begin{array}{l}\text { Can the other forms of government } \\
\text { support be availed over and above the } \\
\text { government financial support through } \\
\text { various instruments listed above? }\end{array}$ & $\begin{array}{l}\text { Yes/No/Not Applicable/ } \\
\text { Unavailable }\end{array}$ & \\
\hline \multirow{17}{*}{$\begin{array}{l}\text { Project } \\
\text { development } \\
\text { funding support }\end{array}$} & $\begin{array}{l}\text { What are the various sources of funds for } \\
\text { PPP project preparation? }\end{array}$ & & \multirow{17}{*}{$\begin{array}{l}\text { Details on various sources } \\
\text { through which funding } \\
\text { could be availed for the } \\
\text { development activities } \\
\text { (preparation, structuring, } \\
\text { and procurement) for a PPP } \\
\text { project } \\
\text { Details on stages of the PPP } \\
\text { project development stage } \\
\text { during which such funding } \\
\text { could be availed and } \\
\text { utilized, including payments } \\
\text { to transaction advisors }\end{array}$} \\
\hline & - Budgetary allocations & $\begin{array}{l}\text { Yes/No/Not Applicable/ } \\
\text { Unavailable }\end{array}$ & \\
\hline & $\begin{array}{l}\text { - Dedicated project preparation/project } \\
\text { development fund }\end{array}$ & $\begin{array}{l}\text { Yes/No/Not Applicable/ } \\
\text { Unavailable }\end{array}$ & \\
\hline & $\begin{array}{l}\text { - Technical assistance from multilateral, } \\
\text { bilateral, and donor agencies? }\end{array}$ & $\begin{array}{l}\text { Yes/No/Not Applicable/ } \\
\text { Unavailable }\end{array}$ & \\
\hline & $\begin{array}{l}\text { - Recovery of project preparation funding } \\
\text { from the preferred bidder? }\end{array}$ & $\begin{array}{l}\text { Yes/No/Not Applicable/ } \\
\text { Unavailable }\end{array}$ & \\
\hline & $\begin{array}{l}\text { At what stage of the PPP project can the } \\
\text { project preparation/development funding } \\
\text { be availed by the government agency? }\end{array}$ & & \\
\hline & - Pre-feasibility stage & $\begin{array}{l}\text { Yes/No/Not Applicable/ } \\
\text { Unavailable }\end{array}$ & \\
\hline & - Detailed feasibility stage & $\begin{array}{l}\text { Yes/No/Not Applicable/ } \\
\text { Unavailable }\end{array}$ & \\
\hline & - Transaction stage & $\begin{array}{l}\text { Yes/No/Not Applicable/ } \\
\text { Unavailable }\end{array}$ & \\
\hline & $\begin{array}{l}\text { Is there a list of project preparation/project } \\
\text { development activities toward which } \\
\text { the project development funding can be } \\
\text { utilized? }\end{array}$ & $\begin{array}{c}\text { Yes/No/Not Applicable/ } \\
\text { Unavailable }\end{array}$ & \\
\hline & $\begin{array}{l}\text { Can the project development funding be } \\
\text { utilized to appoint transaction advisors for } \\
\text { PPP projects? }\end{array}$ & $\begin{array}{l}\text { Yes/No/Not Applicable/ } \\
\text { Unavailable }\end{array}$ & \\
\hline & $\begin{array}{l}\text { Is there a specific process to be followed } \\
\text { by government agencies to appoint } \\
\text { transaction advisors? }\end{array}$ & $\begin{array}{c}\text { Yes/No/Not Applicable/ } \\
\text { Unavailable }\end{array}$ & \\
\hline & $\begin{array}{l}\text { What are the payment mechanisms for } \\
\text { making payments to transaction advisors? }\end{array}$ & $\begin{array}{c}\text { Yes/No/Not Applicable/ } \\
\text { Unavailable }\end{array}$ & \\
\hline & - Timesheet based & $\begin{array}{l}\text { Yes/No/Not Applicable/ } \\
\text { Unavailable }\end{array}$ & \\
\hline & - Milestone based & $\begin{array}{l}\text { Yes/No/Not Applicable/ } \\
\text { Unavailable }\end{array}$ & \\
\hline & $\begin{array}{l}\text { Are there standard agreements and } \\
\text { documents to avail project development } \\
\text { funding? }\end{array}$ & $\begin{array}{c}\text { Yes/No/Not Applicable/ } \\
\text { Unavailable }\end{array}$ & \\
\hline & $\begin{array}{l}\text { Who are the signatories to the project } \\
\text { development funding agreements? }\end{array}$ & & \\
\hline
\end{tabular}


Table A1. 2 continued

\begin{tabular}{|c|c|c|c|}
\hline Subcategory & Supporting Indicators & Units & Definition \\
\hline \multirow[t]{6}{*}{$\begin{array}{l}\text { PPP project } \\
\text { statistics }\end{array}$} & $\begin{array}{l}\text { Is there a National PPP database for the } \\
\text { country? }\end{array}$ & $\begin{array}{l}\text { Yes/No/Not Applicable/ } \\
\text { Unavailable }\end{array}$ & \multirow{6}{*}{$\begin{array}{l}\text { Details on the key PPP } \\
\text { statistics in the country, } \\
\text { such as (i) availability of } \\
\text { a PPP database showing } \\
\text { distribution of PPP } \\
\text { projects across sectors } \\
\text { and across various stages } \\
\text { of the PPP life cycle, and } \\
\text { (ii) availability of a national } \\
\text { PPP project pipeline and its } \\
\text { alignment with the National } \\
\text { Infrastructure Plan for the } \\
\text { country }\end{array}$} \\
\hline & $\begin{array}{l}\text { Is the distribution of PPP projects across } \\
\text { infrastructure sectors available? }\end{array}$ & $\begin{array}{c}\text { Yes/No/Not Applicable/ } \\
\text { Unavailable }\end{array}$ & \\
\hline & $\begin{array}{l}\text { Is the distribution of PPP projects across } \\
\text { various stages of the PPP life cycle } \\
\text { available? }\end{array}$ & $\begin{array}{l}\text { Yes/No/Not Applicable/ } \\
\text { Unavailable }\end{array}$ & \\
\hline & $\begin{array}{l}\text { Does the country publish a national PPP } \\
\text { project pipeline? }\end{array}$ & $\begin{array}{l}\text { Yes/No/Not Applicable/ } \\
\text { Unavailable }\end{array}$ & \\
\hline & $\begin{array}{l}\text { At what frequency is the national PPP } \\
\text { project pipeline published? }\end{array}$ & & \\
\hline & $\begin{array}{l}\text { Is the national PPP project pipeline based } \\
\text { on the National Infrastructure Plan for the } \\
\text { country? }\end{array}$ & $\begin{array}{l}\text { Yes/No/Not Applicable/ } \\
\text { Unavailable }\end{array}$ & \\
\hline \multirow[t]{14}{*}{$\begin{array}{l}\text { Sources of PPP } \\
\text { financing }\end{array}$} & $\begin{array}{l}\text { Who are the typical entities financing PPP } \\
\text { projects in the country? }\end{array}$ & $\begin{array}{l}\text { Yes/No/Not Applicable/ } \\
\text { Unavailable }\end{array}$ & \multirow{14}{*}{$\begin{array}{l}\text { Details on the sources of } \\
\text { financing for PPP projects in } \\
\text { the country } \\
\text { Details on typical key } \\
\text { financing terms for various } \\
\text { sources of financing, banks } \\
\text { active in project finance for } \\
\text { the last } 24 \text { months, active } \\
\text { PPP project sponsors in } \\
\text { the country for the last } \\
24 \text { months, availability of } \\
\text { derivatives market, and } \\
\text { availability of credit rating } \\
\text { agencies in the country }\end{array}$} \\
\hline & - Private developers & $\begin{array}{c}\text { Yes/No/Not Applicable/ } \\
\text { Unavailable }\end{array}$ & \\
\hline & - Construction contractors & $\begin{array}{c}\text { Yes/No/Not Applicable/ } \\
\text { Unavailable }\end{array}$ & \\
\hline & $\begin{array}{l}\text { - Institutional/financial/private equity } \\
\text { investors }\end{array}$ & $\begin{array}{c}\text { Yes/No/Not Applicable/ } \\
\text { Unavailable }\end{array}$ & \\
\hline & - Pension funds & $\begin{array}{c}\text { Yes/No/Not Applicable/ } \\
\text { Unavailable }\end{array}$ & \\
\hline & - Insurance companies & $\begin{array}{c}\text { Yes/No/Not Applicable/ } \\
\text { Unavailable }\end{array}$ & \\
\hline & - Banks & $\begin{array}{c}\text { Yes/No/Not Applicable/ } \\
\text { Unavailable }\end{array}$ & \\
\hline & $\begin{array}{l}\text { - Non-banking financial corporation/ } \\
\text { financial institutions }\end{array}$ & $\begin{array}{c}\text { Yes/No/Not Applicable/ } \\
\text { Unavailable }\end{array}$ & \\
\hline & - Donor agencies & $\begin{array}{l}\text { Yes/No/Not Applicable/ } \\
\text { Unavailable }\end{array}$ & \\
\hline & $\begin{array}{l}\text { Government agencies and state-owned } \\
\text { enterprises }\end{array}$ & $\begin{array}{c}\text { Yes/No/Not Applicable/ } \\
\text { Unavailable }\end{array}$ & \\
\hline & $\begin{array}{l}\text { What is the distribution of financing among } \\
\text { these entities financing PPP projects? }\end{array}$ & & \\
\hline & $\begin{array}{l}\text { Does the country have the history/track } \\
\text { record of issuing bonds by infrastructure } \\
\text { projects? }\end{array}$ & $\begin{array}{l}\text { Yes/No/Not Applicable/ } \\
\text { Unavailable }\end{array}$ & \\
\hline & $\begin{array}{l}\text { How many infrastructure projects/private } \\
\text { developers for infrastructure projects have } \\
\text { raised funding through bond issuances? }\end{array}$ & Number & \\
\hline & $\begin{array}{l}\text { What is the value of funding raised through } \\
\text { capital markets by PPPs? }\end{array}$ & Number & \\
\hline
\end{tabular}


Table A1. 2 continued

\begin{tabular}{|c|c|c|c|}
\hline Subcategory & Supporting Indicators & Units & Definition \\
\hline & $\begin{array}{l}\text { Does the country have a matured } \\
\text { derivatives market to hedge certain risks } \\
\text { associated with PPPs? }\end{array}$ & $\begin{array}{c}\text { Yes/No/Not Applicable/ } \\
\text { Unavailable }\end{array}$ & \\
\hline & $\begin{array}{l}\text { Does the country have a national } \\
\text { development bank? }\end{array}$ & $\begin{array}{l}\text { Yes/No/Not Applicable/ } \\
\text { Unavailable }\end{array}$ & \\
\hline & $\begin{array}{l}\text { Does the country have credit rating } \\
\text { agencies to rate infrastructure projects? }\end{array}$ & $\begin{array}{l}\text { Yes/No/Not Applicable/ } \\
\text { Unavailable }\end{array}$ & \\
\hline & $\begin{array}{l}\text { Typically, what are the credit ratings } \\
\text { achieved/received by infrastructure } \\
\text { projects? }\end{array}$ & $\begin{array}{l}\text { Yes/No/Not Applicable/ } \\
\text { Unavailable }\end{array}$ & \\
\hline & $\begin{array}{l}\text { Is there a threshold credit rating for } \\
\text { infrastructure PPPs below which } \\
\text { institutional investors, pension funds, and } \\
\text { insurance companies would not invest in } \\
\text { infrastructure PPPs? }\end{array}$ & $\begin{array}{c}\text { Yes/No/Not Applicable/ } \\
\text { Unavailable }\end{array}$ & \\
\hline & $\begin{array}{l}\text { What is the typical funding model for } \\
\text { infrastructure PPPs - corporate finance or } \\
\text { project finance? }\end{array}$ & & \\
\hline & $\begin{array}{l}\text { Are there regulatory limits/restrictions for } \\
\text { the maximum exposure that can be taken } \\
\text { by banks to infrastructure projects? }\end{array}$ & $\begin{array}{c}\text { Yes/No/Not Applicable/ } \\
\text { Unavailable }\end{array}$ & \\
\hline
\end{tabular}

Table A1.3: Sector-Specific Public-Private Partnership Landscape

\begin{tabular}{|c|c|c|c|}
\hline Subcategory & Supporting Indicators & Units & Definition \\
\hline $\begin{array}{l}\text { Contracting } \\
\text { agencies in the } \\
\text { sector }\end{array}$ & None & Description & $\begin{array}{l}\text { Details on which } \\
\text { government agencies could } \\
\text { act as the contracting } \\
\text { agencies for a PPP project }\end{array}$ \\
\hline $\begin{array}{l}\text { Sector laws and } \\
\text { regulations }\end{array}$ & None & Description & $\begin{array}{l}\text { Details on the applicable } \\
\text { sector laws and regulations } \\
\text { for PPP projects including } \\
\text { the sector regulators and } \\
\text { their respective functions }\end{array}$ \\
\hline $\begin{array}{l}\text { Foreign } \\
\text { investment } \\
\text { restrictions in } \\
\text { the sector }\end{array}$ & $\begin{array}{l}\text { Maximum allowed foreign ownership of } \\
\text { equity in greenfield projects }\end{array}$ & $\%$ & $\begin{array}{l}\text { Details on the maximum } \\
\text { allowed foreign equity } \\
\text { investment in greenfield } \\
\text { PPP projects in a particular } \\
\text { sector }\end{array}$ \\
\hline \multirow{3}{*}{$\begin{array}{l}\text { Standard } \\
\text { contracts in the } \\
\text { sector }\end{array}$} & PPP/concession agreement & $\begin{array}{l}\text { Yes/No/Not Applicable/ } \\
\text { Unavailable }\end{array}$ & \multirow{3}{*}{$\begin{array}{l}\text { Specifics of whether } \\
\text { standard contracts are } \\
\text { available for PPP projects in } \\
\text { a particular sector }\end{array}$} \\
\hline & $\begin{array}{l}\text { Performance-based operation and } \\
\text { maintenance contract }\end{array}$ & $\begin{array}{l}\text { Yes/No/Not Applicable/ } \\
\text { Unavailable }\end{array}$ & \\
\hline & $\begin{array}{l}\text { Engineering procurement and construction } \\
\text { contract }\end{array}$ & $\begin{array}{c}\text { Yes/No/Not Applicable/ } \\
\text { Unavailable }\end{array}$ & \\
\hline
\end{tabular}


Table A1.3 continued

\begin{tabular}{|c|c|c|c|}
\hline Subcategory & Supporting Indicators & Units & Definition \\
\hline $\begin{array}{l}\text { Sector master } \\
\text { plan }\end{array}$ & None & Description & $\begin{array}{l}\text { Details on the master } \\
\text { plan and/or road map } \\
\text { adopted for infrastructure } \\
\text { development in the sector } \\
\text { by the national government } \\
\text { and the corresponding line } \\
\text { ministry } \\
\text { Details on the pipeline } \\
\text { of PPP projects for the } \\
\text { sector aligned with the } \\
\text { sector master plan and/or } \\
\text { road map } \\
\text { Details on the PPP projects } \\
\text { under preparation and } \\
\text { procurement in the sector }\end{array}$ \\
\hline \multirow[t]{5}{*}{$\begin{array}{l}\text { Features of past } \\
\text { PPP projects }\end{array}$} & $\begin{array}{l}\text { Number of PPP projects procured through } \\
\text { various modes of PPP procurement- } \\
\text { Direct Appointment, Unsolicited Bids, and } \\
\text { Competitive Bids }\end{array}$ & Number & \multirow{5}{*}{$\begin{array}{l}\text { Features of past PPP } \\
\text { projects based on } \\
\text { supporting indicators in } \\
\text { terms of the number and } \\
\text { value (where applicable) } \\
\text { of PPP projects for each } \\
\text { supporting indicator }\end{array}$} \\
\hline & $\begin{array}{l}\text { Number and value of PPP projects reaching } \\
\text { financial closure }\end{array}$ & Number & \\
\hline & $\begin{array}{l}\text { Number of PPP projects with foreign } \\
\text { sponsor participation in absolute terms, } \\
\text { and as a percentage of total number of PPP } \\
\text { projects }\end{array}$ & Number & \\
\hline & $\begin{array}{l}\text { Number of PPP projects supported with } \\
\text { various forms of government financial } \\
\text { support-Viability Gap Fund, Government } \\
\text { Guarantees, and Availability/ Performance } \\
\text { Payments }\end{array}$ & Number & \\
\hline & $\begin{array}{l}\text { Number of PPP projects based on various } \\
\text { types of payment mechanisms-User } \\
\text { Charges, and Government Pay (Offtake) }\end{array}$ & Number & \\
\hline $\begin{array}{l}\text { Tariffs } \\
\text { applicable to the } \\
\text { sector }\end{array}$ & None & Description & $\begin{array}{l}\text { Details on the indicative } \\
\text { tariffs applicable in the } \\
\text { sector based on the } \\
\text { examples of select PPP or } \\
\text { other projects operational } \\
\text { in the sector }\end{array}$ \\
\hline $\begin{array}{l}\text { Typical risk } \\
\text { allocation for } \\
\text { PPP projects in } \\
\text { the sector }\end{array}$ & Traffic risk & $\begin{array}{l}\text { Yes/No/Not Applicable/ } \\
\text { Unavailable }\end{array}$ & $\begin{array}{l}\text { Details on the typical risk } \\
\text { allocation between the } \\
\text { government contracting } \\
\text { agency and the private } \\
\text { partner based on examples } \\
\text { of select PPP projects which } \\
\text { have achieved commercial } \\
\text { close }\end{array}$ \\
\hline
\end{tabular}


Table A1.3 continued

\begin{tabular}{|c|c|c|c|}
\hline Subcategory & Supporting Indicators & Units & Definition \\
\hline \multirow{12}{*}{ (n) } & Collection risk & $\begin{array}{c}\text { Yes/No/Not Applicable/ } \\
\text { Unavailable }\end{array}$ & \\
\hline & Competition risk & $\begin{array}{c}\text { Yes/No/Not Applicable/ } \\
\text { Unavailable }\end{array}$ & \\
\hline & Government payment risk & $\begin{array}{c}\text { Yes/No/Not Applicable/ } \\
\text { Unavailable }\end{array}$ & \\
\hline & Environmental and social risk & $\begin{array}{c}\text { Yes/No/Not Applicable/ } \\
\text { Unavailable }\end{array}$ & \\
\hline & Land acquisition risk & $\begin{array}{c}\text { Yes/No/Not Applicable/ } \\
\text { Unavailable }\end{array}$ & \\
\hline & Permits & $\begin{array}{c}\text { Yes/No/Not Applicable/ } \\
\text { Unavailable }\end{array}$ & \\
\hline & Geotechnical risk & $\begin{array}{l}\text { Yes/No/Not Applicable/ } \\
\text { Unavailable }\end{array}$ & \\
\hline & $\begin{array}{l}\text { Brownfield risk: inventories studies, } \\
\text { property boundaries, project scope }\end{array}$ & $\begin{array}{c}\text { Yes/No/Not Applicable/ } \\
\text { Unavailable }\end{array}$ & \\
\hline & Political risk & $\begin{array}{c}\text { Yes/No/Not Applicable/ } \\
\text { Unavailable }\end{array}$ & \\
\hline & Force majeure & $\begin{array}{c}\text { Yes/No/Not Applicable/ } \\
\text { Unavailable }\end{array}$ & \\
\hline & Foreign exchange risk & $\begin{array}{c}\text { Yes/No/Not Applicable/ } \\
\text { Unavailable }\end{array}$ & \\
\hline & Construction risk & $\begin{array}{l}\text { Yes/No/Not Applicable/ } \\
\text { Unavailable }\end{array}$ & \\
\hline \multirow{6}{*}{$\begin{array}{l}\text { Financing details } \\
\text { for PPP projects } \\
\text { in the sector }\end{array}$} & $\begin{array}{l}\text { PPP projects with foreign lending } \\
\text { participation }\end{array}$ & Number & \multirow{6}{*}{$\begin{array}{l}\text { Typical financing details } \\
\text { based on past PPP } \\
\text { projects on the lines of the } \\
\text { supporting indicators }\end{array}$} \\
\hline & $\begin{array}{l}\text { PPP projects that received export credit } \\
\text { agency/international financing institution } \\
\text { support }\end{array}$ & Number & \\
\hline & Typical debt: Equity ratio & Ratio & \\
\hline & Time for financial closure & Months & \\
\hline & Typical concession period & Years & \\
\hline & Typical Financial Internal Rate of Return & $\%$ & \\
\hline $\begin{array}{l}\text { Challenges } \\
\text { associated with } \\
\text { PPPs in the } \\
\text { sector }\end{array}$ & None & Description & $\begin{array}{l}\text { Details on the PPP-related } \\
\text { and sector-specific } \\
\text { challenges faced by PPP } \\
\text { projects in the sector }\end{array}$ \\
\hline
\end{tabular}


Table A1.4: Typical Sector-Specific Infrastructure Indicators for the Country

\begin{tabular}{|c|c|c|c|}
\hline Subcategory & Supporting Indicators & Units & Definition \\
\hline \multirow[t]{2}{*}{ Roads } & Length of the total road network & kilometers & \\
\hline & Quality of road infrastructure & 1(low) -7 (high) & \\
\hline \multirow[t]{4}{*}{ Railways } & Length of total railway network & total route-km & \\
\hline & Total number of passengers carried & Million passenger-km & \\
\hline & Total volume of freight carried & Million ton-km & \\
\hline & Quality of railways infrastructure & 1(low) -7 (high) & \\
\hline \multirow[t]{5}{*}{ Ports } & Total number of ports & Number & \\
\hline & Total freight capacity of all ports & MTPA & \\
\hline & Total container traffic at ports & TEUs & \\
\hline & Quality of port infrastructure & $1($ low $)-7$ (high) & \\
\hline & $\begin{array}{l}\text { Quality of trade and transport-related } \\
\text { infrastructure index }\end{array}$ & $1=$ low to $5=$ high & \\
\hline \multirow[t]{5}{*}{ Airports } & No. of airports & Number & \\
\hline & Total passenger capacity & million passengers & \\
\hline & Quality of air transport infrastructure & 1 (low) -7 (high) & \\
\hline & $\begin{array}{l}\text { Total number of projects with cumulative lending, } \\
\text { grant, and technical assistance commitments in } \\
\text { the transport sector }\end{array}$ & Number & \\
\hline & $\begin{array}{l}\text { Total amount of cumulative lending, grant, and } \\
\text { technical assistance commitments in the transport } \\
\text { sector }\end{array}$ & $\$$ million & \\
\hline \multirow[t]{8}{*}{ Energy } & Electric power consumption & kilowatt-hour per capita & \\
\hline & Share of clean energy & $\%$ of total energy use & \\
\hline & Access to electricity & $\%$ of population & \\
\hline & Getting electricity (score out of 100) & Number & \\
\hline & Energy imports & $\%$ of total energy use & \\
\hline & Investment in energy with private participation & current $\$$ million & \\
\hline & $\begin{array}{l}\text { Total number of projects with cumulative lending, } \\
\text { grant, and technical assistance commitments in } \\
\text { the energy sector }\end{array}$ & Number & \\
\hline & $\begin{array}{l}\text { Total amount of cumulative lending, grant, and } \\
\text { technical assistance commitments in the energy } \\
\text { sector }\end{array}$ & $\$$ million & \\
\hline \multirow{3}{*}{$\begin{array}{l}\text { Water and } \\
\text { Wastewater }\end{array}$} & Improved water source access & $\%$ of population with access & \\
\hline & Improved sanitation facilities access & $\%$ of population with access & \\
\hline & $\begin{array}{l}\text { Investment in water and sanitation with private } \\
\text { participation }\end{array}$ & current $\$$ million & \\
\hline
\end{tabular}


Table A1.4 continued

\begin{tabular}{|c|c|c|c|}
\hline \multirow{3}{*}{ Subcategory } & Supporting Indicators & Units & \multirow[t]{3}{*}{ Definition } \\
\hline & $\begin{array}{l}\text { Total number of projects with cumulative lending, } \\
\text { grant, and technical assistance commitments in } \\
\text { water and other urban infrastructure and services }\end{array}$ & Number & \\
\hline & $\begin{array}{l}\text { Total amount of cumulative lending, grant, and } \\
\text { technical assistance commitments in water and } \\
\text { other urban infrastructure and services }\end{array}$ & $\$$ million & \\
\hline \multirow[t]{7}{*}{$\mathrm{ICT}$} & Telephone subscribers & per 100 inhabitants & \\
\hline & Cellular Phone Subscribers & per 100 inhabitants & \\
\hline & Cellular Network Coverage & $\%$ of population covered & \\
\hline & Internet Subscribers & per 100 inhabitants & \\
\hline & Internet Bandwidth per Internet User & kbps & \\
\hline & $\begin{array}{l}\text { Total number of projects with Cumulative Lending, } \\
\text { Grant, and Technical Assistance Commitments in } \\
\text { ICT sector }\end{array}$ & Number & \\
\hline & $\begin{array}{l}\text { Total amount of Cumulative Lending, Grant, and } \\
\text { Technical Assistance Commitments in ICT sector }\end{array}$ & $\$$ million & \\
\hline \multirow{16}{*}{$\begin{array}{l}\text { Social } \\
\text { infrastructure }\end{array}$} & Government Expenditure on Education & $\%$ of GDP & \\
\hline & Education spending as \% of government spending & $\%$ & \\
\hline & Primary School Gross Enrollment & $\%$ & \\
\hline & Adult Literacy Rate & $\%$ & \\
\hline & $\begin{array}{l}\text { Total number of projects with Cumulative Lending, } \\
\text { Grant, and Technical Assistance Commitments in } \\
\text { education sector }\end{array}$ & Number & \\
\hline & $\begin{array}{l}\text { Total amount of Cumulative Lending, Grant, and } \\
\text { Technical Assistance Commitments in education } \\
\text { sector }\end{array}$ & $\$$ million & \\
\hline & Total Health Expenditure & $\%$ of GDP & \\
\hline & Health spending per capita & USD & \\
\hline & $\begin{array}{l}\text { Maternal Mortality Ratio (modeled estimates per } \\
100,000 \text { live births) }\end{array}$ & (per 100,000 live births) & \\
\hline & Infant Mortality Rate & $\begin{array}{c}\text { (below } 1 \text { year/per } 1,000 \text { live } \\
\text { births) }\end{array}$ & \\
\hline & Life Expectancy at Birth & (years) & \\
\hline & Child Malnutrition & (\% below 5 years old) & \\
\hline & $\begin{array}{l}\text { Total number of projects with Cumulative Lending, } \\
\text { Grant, and Technical Assistance Commitments in } \\
\text { health sector }\end{array}$ & Number & \\
\hline & $\begin{array}{l}\text { Total amount of Cumulative Lending, Grant, and } \\
\text { Technical Assistance Commitments in health } \\
\text { sector }\end{array}$ & $\$$ million & \\
\hline & Existing No. of Affordable Housing Units & Number & \\
\hline & Affordable Housing Gap & & \\
\hline
\end{tabular}


Table A1.5: Local Government Public-Private Partnership Landscape

\begin{tabular}{|c|c|c|c|}
\hline Subcategory & Supporting Indicators & Units & Definition \\
\hline \multirow{28}{*}{$\begin{array}{l}\text { Key indicators } \\
\text { related to local } \\
\text { governments in } \\
\text { the country }\end{array}$} & $\begin{array}{l}\text { Number of Subnational Governments } \\
\text { (SNGs) }\end{array}$ & & \multirow{28}{*}{$\begin{array}{l}\text { Details on the local } \\
\text { governments using select } \\
\text { key indicators on (i) the } \\
\text { number and levels of local } \\
\text { governments, (ii) the } \\
\text { typical expenditure profile } \\
\text { and heads, (iii) the typical } \\
\text { revenue profile and heads, } \\
\text { (iv) the typical debt profile } \\
\text { and heads, and (v) grants } \\
\text { and transfers from the } \\
\text { higher levels of government }\end{array}$} \\
\hline & - Municipal Level & Number & \\
\hline & - Intermediate Level & Number & \\
\hline & - Regional or State Level & Number & \\
\hline & Total number of SNGs & Number & \\
\hline & SNG Expenditure Profile & SNG Expenditure Profile & \\
\hline & Total SNG Expenditure as \% of GDP & $\%$ & \\
\hline & - SNG Current Expenditure as \% of GDP & $\%$ & \\
\hline & - SNG Staff Expenditure as \% of GDP & $\%$ & \\
\hline & - SNG Investment as \% of GDP & $\%$ & \\
\hline & $\begin{array}{l}\text { Total SNG Expenditure as } \% \text { of the Total } \\
\text { General Government (\% of Total Public } \\
\text { Expenditure) }\end{array}$ & $\%$ & \\
\hline & $\begin{array}{l}\text { - SNG Current Expenditure as a \% } \\
\text { of Total Current Expenditure of the } \\
\text { General Government }\end{array}$ & $\%$ & \\
\hline & $\begin{array}{l}\text { - SNG Staff Expenditure as a \% of Total } \\
\text { Staff Expenditure of the General } \\
\text { Government }\end{array}$ & $\%$ & \\
\hline & $\begin{array}{l}\text { - SNG Investment as a \% of Total } \\
\text { Investment of the General Government }\end{array}$ & $\%$ & \\
\hline & $\begin{array}{l}\text { Current Expenditure of SNG as a \% of Total } \\
\text { SNG Expenditure }\end{array}$ & $\%$ & \\
\hline & $\begin{array}{l}\text { Staff Expenditure of SNG as a \% of Total } \\
\text { SNG Expenditure }\end{array}$ & $\%$ & \\
\hline & $\begin{array}{l}\text { Investments of SNG as a \% of Total SNG } \\
\text { Expenditure }\end{array}$ & $\%$ & \\
\hline & SNG Expenditure by Function & $\begin{array}{l}\text { SNG Expenditure by } \\
\text { Function }\end{array}$ & \\
\hline & - General Public Services & $\%$ & \\
\hline & - Defence & $\%$ & \\
\hline & - Security and Public Order & $\%$ & \\
\hline & - Economic Affairs & $\%$ & \\
\hline & - Environmental Protection & $\%$ & \\
\hline & - Housing and Community Amenities & $\%$ & \\
\hline & - Health & $\%$ & \\
\hline & - Recreation, Culture, and Religion & $\%$ & \\
\hline & - Education & $\%$ & \\
\hline & - Social Protection & $\%$ & \\
\hline
\end{tabular}


Table A1.5 continued

\begin{tabular}{|c|c|c|c|}
\hline Subcategory & Supporting Indicators & Units & Definition \\
\hline & SNG Revenue Profile & SNG Revenue Profile & \\
\hline & Total SNG Revenue as a \% of GDP & $\%$ & \\
\hline & - SNG Tax Revenue as a \% of GDP & $\%$ & \\
\hline & - SNG Grants and Subsidies as a \% of GDP & $\%$ & \\
\hline & - SNG Other Revenues as a \% of GDP & $\%$ & \\
\hline & $\begin{array}{l}\text { Total SNG Revenue as \% of Total General } \\
\text { Government Revenue }\end{array}$ & $\%$ & \\
\hline & $\begin{array}{l}\text { - SNG Tax Revenue as a \% of Total } \\
\text { General Government Tax Revenue }\end{array}$ & $\%$ & \\
\hline & $\begin{array}{l}\text { - SNG Grants and Subsidies as a \% of } \\
\text { Total General Government Grants and } \\
\text { Subsidies }\end{array}$ & $\%$ & \\
\hline & $\begin{array}{l}\text { - SNG Other Revenues as a \% of Total } \\
\text { Other Revenues }\end{array}$ & $\%$ & \\
\hline & $\begin{array}{l}\text { SNG Tax Revenue as a \% of Total SNG } \\
\text { Revenue }\end{array}$ & $\%$ & \\
\hline & $\begin{array}{l}\text { SNG Grants and Subsidies as a \% of Total } \\
\text { SNG Revenue }\end{array}$ & $\%$ & \\
\hline & $\begin{array}{l}\text { SNG Other Revenues as a \% of Total SNG } \\
\text { Revenue }\end{array}$ & $\%$ & \\
\hline & SNG Debt Profile & SNG Debt Profile & \\
\hline & Outstanding SNG Debt as \% of GDP & $\%$ & \\
\hline & $\begin{array}{l}\text { Outstanding SNG Debt as \% of Total } \\
\text { Outstanding Debt of General Government }\end{array}$ & $\%$ & \\
\hline & $\begin{array}{l}\text { Parameters for transfers to the Subnational } \\
\text { Governments from the National } \\
\text { Government }\end{array}$ & $\begin{array}{l}\text { Parameters for transfers } \\
\text { to the Subnational } \\
\text { Governments from the } \\
\text { National Government }\end{array}$ & \\
\hline & $\begin{array}{l}\text { Score on transfers to Subnational } \\
\text { Governments }\end{array}$ & & \\
\hline & - Score on system for allocating transfers & & \\
\hline & $\begin{array}{l}\text { - Score on timeliness of information on } \\
\text { transfers }\end{array}$ & & \\
\hline & $\begin{array}{l}\text { - Score on extent of collection and } \\
\text { reporting of consolidated fiscal data for } \\
\text { general government }\end{array}$ & & \\
\hline & $\begin{array}{l}\text { Value of Central Government transfers to } \\
\text { Subnational Governments }\end{array}$ & $\%$ of the GDP & \\
\hline & $\begin{array}{l}\text { Value of Actual budgetary allocation to } \\
\text { Subnational Governments from National } \\
\text { Government }\end{array}$ & $\%$ of total expenditure & \\
\hline & $\begin{array}{l}\text { Value of Deviation of actual against } \\
\text { the budgeted transfers to Subnational } \\
\text { Governments }\end{array}$ & $\%$ of budgeted transfers & \\
\hline
\end{tabular}


Table A1.5 continued

\begin{tabular}{|c|c|c|c|}
\hline Subcategory & Supporting Indicators & Units & Definition \\
\hline $\begin{array}{l}\text { Local } \\
\text { governance } \\
\text { system }\end{array}$ & None & Description & $\begin{array}{l}\text { Details on the local } \\
\text { governance system in } \\
\text { the country, including } \\
\text { the various levels of } \\
\text { local governments; their } \\
\text { roles, responsibilities } \\
\text { and functions; and the } \\
\text { devolution of powers } \\
\text { from the higher levels } \\
\text { of government to these } \\
\text { various levels of local } \\
\text { governments. }\end{array}$ \\
\hline $\begin{array}{l}\text { Infrastructure } \\
\text { development } \\
\text { plan for local } \\
\text { governments }\end{array}$ & None & Description & $\begin{array}{l}\text { Details on the infrastructure } \\
\text { development plans preparec } \\
\text { by the local governments } \\
\text { based on their capital } \\
\text { investment projects in the } \\
\text { pipeline, and the coverage } \\
\text { of such infrastructure } \\
\text { development plans. }\end{array}$ \\
\hline $\begin{array}{l}\text { PPP enabling } \\
\text { framework } \\
\text { for local } \\
\text { governments }\end{array}$ & None & Description & $\begin{array}{l}\text { Details on the PPP enabling } \\
\text { framework applicable to } \\
\text { local government PPP } \\
\text { projects, including PPP legal } \\
\text { and regulatory framework, } \\
\text { PPP policy framework, and } \\
\text { PPP institutional framework }\end{array}$ \\
\hline $\begin{array}{l}\text { Eligible } \\
\text { sectors for } \\
\text { PPPs for local } \\
\text { governments }\end{array}$ & None & Description & $\begin{array}{l}\text { Details on the eligible } \\
\text { sectors in which PPPs could } \\
\text { be undertaken by local } \\
\text { government as government } \\
\text { contracting agency }\end{array}$ \\
\hline $\begin{array}{l}\text { Revenues } \\
\text { for local } \\
\text { governments }\end{array}$ & None & Description & $\begin{array}{l}\text { Details on the typical } \\
\text { sources of revenue for local } \\
\text { governments }\end{array}$ \\
\hline $\begin{array}{l}\text { Borrowings } \\
\text { by local } \\
\text { governments }\end{array}$ & None & Description & $\begin{array}{l}\text { Details on the typical } \\
\text { sources of debt financing } \\
\text { available for local } \\
\text { governments, the purpose } \\
\text { for which borrowed funds } \\
\text { could be used, the terms } \\
\text { of such borrowings, and } \\
\text { the borrowing exposure of } \\
\text { select local governments }\end{array}$ \\
\hline $\begin{array}{l}\text { Budgetary } \\
\text { allocation } \\
\text { to local } \\
\text { governments }\end{array}$ & None & Description & $\begin{array}{l}\text { Details on the budgetary } \\
\text { allocations and transfers } \\
\text { to the local governments } \\
\text { from the higher levels of } \\
\text { government }\end{array}$ \\
\hline
\end{tabular}


Table A1.5 continued

\begin{tabular}{|l|l|l|l|}
\hline $\begin{array}{l}\text { Subcategory } \\
\text { Credit rating } \\
\text { of local } \\
\text { governments }\end{array}$ & None & \multicolumn{1}{|c|}{$\begin{array}{c}\text { Units } \\
\text { Description }\end{array}$} & $\begin{array}{l}\text { Definition } \\
\text { Details on the precedence } \\
\text { of local governments } \\
\text { being rated by credit rating } \\
\text { agencies in the country } \\
\text { Details of credit ratings } \\
\text { obtained by select local } \\
\text { governments in the past }\end{array}$ \\
\hline $\begin{array}{l}\text { Case study } \\
\text { on a local } \\
\text { government PPP }\end{array}$ & None & $\begin{array}{l}\text { A case of a PPP project } \\
\text { undertaken by a local } \\
\text { government in the past, } \\
\text { which covers details on } \\
\text { project background, project } \\
\text { assets, PPP structure for } \\
\text { the project, risk allocation } \\
\text { among the parties for the } \\
\text { project, project finance and } \\
\text { project revenue details, and } \\
\text { key learnings from the PPP } \\
\text { project }\end{array}$ \\
\hline
\end{tabular}

Table A1.6: Critical Macroeconomic and Infrastructure Sector Indicators for the Country

\begin{tabular}{|c|c|c|c|}
\hline Subcategory & Supporting Indicators & Units & Definition \\
\hline \multirow{17}{*}{$\begin{array}{l}\text { Critical macro- } \\
\text { economic and } \\
\text { infrastructure } \\
\text { sector indicators }\end{array}$} & Total population & million & \multirow{17}{*}{$\begin{array}{l}\text { Details of major } \\
\text { macroeconomic } \\
\text { indicators for the } \\
\text { country }\end{array}$} \\
\hline & Average annual population growth rate & $\%$ & \\
\hline & Population density & $\begin{array}{c}\text { persons per square } \\
\text { kilometer }\left(\mathrm{km}^{2}\right) \text { of surface } \\
\text { area }\end{array}$ & \\
\hline & Urban population & $\%$ of total population & \\
\hline & Surface area & '000 km² & \\
\hline & Unemployment rate & $\%$ & \\
\hline & $\begin{array}{l}\text { Proportion of population below } \$ 1.90 \text { purchasing } \\
\text { power parity (PPP) a day }\end{array}$ & $\%$ & \\
\hline & Nominal gross domestic product (GDP) & $\$$ billion & \\
\hline & & $\%$ & \\
\hline & Annual growth rate of GDP (2019) & $\%$ & \\
\hline & Annual growth rate of GDP (2020 forecast) & $\%$ & \\
\hline & Annual growth rate of GDP (2021 forecast) & $\%$ & \\
\hline & GDP at purchasing power parity (PPP) per capita & $\$$ at PPP & \\
\hline & GDP at current market prices & $\$$ billion & \\
\hline & Gross fixed investment at current market prices & $\%$ of GDP & \\
\hline & $\begin{array}{l}\text { Per capita gross national income (GNI), Atlas } \\
\text { Method }\end{array}$ & $\$$ & \\
\hline & Inflation rate (2019) & $\%$ & \\
\hline
\end{tabular}


Table A1.6 continued

\begin{tabular}{|c|c|c|c|}
\hline Subcategory & Supporting Indicators & Units & Definition \\
\hline & Inflation rate (2020 forecast) & $\%$ & \\
\hline & Inflation rate (2021 forecast) & $\%$ & \\
\hline & Current account (2019) & $\%$ of GDP & \\
\hline & External trade, goods, value of imports, CIF (2018) & $\$$ billion & \\
\hline & $\begin{array}{l}\text { External trade, goods, value of exports, FOB } \\
(2018)\end{array}$ & $\$$ billion & \\
\hline & CPI \% change over 2018 & $\%$ of CPI in 2018 & \\
\hline & Real effective exchange rate & & \\
\hline & $\begin{array}{l}\text { Investment in energy with private sector } \\
\text { participation }\end{array}$ & Current $\$$ million & \\
\hline & $\begin{array}{l}\text { Investment in transport with private sector } \\
\text { participation }\end{array}$ & Current $\$$ million & \\
\hline & $\begin{array}{l}\text { Investment in water and sanitation with private } \\
\text { sector participation }\end{array}$ & Current $\$$ million & \\
\hline & Logistics Performance Index (LPI) rank & Number & \\
\hline & Logistics Performance Index (LPI) score & Number & \\
\hline & Customs rank & Number & \\
\hline & Customs score & Number & \\
\hline & Infrastructure rank & Number & \\
\hline & Infrastructure score & Number & \\
\hline & International shipments rank & Number & \\
\hline & International shipments score & Number & \\
\hline & Logistics competence rank & Number & \\
\hline & Logistics competence score & Number & \\
\hline & Tracking and tracing rank & Number & \\
\hline & Tracking and tracing score & Number & \\
\hline & Timeliness rank & Number & \\
\hline & Timeliness score & Number & \\
\hline & $\begin{array}{l}\text { Structure of Output (\% of GDP at current } \\
\text { producer | basic prices) }\end{array}$ & & \\
\hline & Agriculture & $\%$ & \\
\hline & Industry & $\%$ & \\
\hline & Services & $\%$ & \\
\hline & Consumer price index (national) & $\%$ annual change & \\
\hline & Producer price index & $\%$ annual change & \\
\hline & Wholesale price index (national) & $\%$ annual change & \\
\hline & Retail price index & $\%$ annual change & \\
\hline & Exchange rates (End of period) & Local currency - \$ & \\
\hline
\end{tabular}


Table A1.6 continued

\begin{tabular}{|c|c|c|c|}
\hline Subcategory & Supporting Indicators & Units & Definition \\
\hline & ADF Portfolio & & \\
\hline & Total number of loans & Number & \\
\hline & 1. Sovereign & Number & \\
\hline & 2. Non-sovereign & Number & \\
\hline & Net loan amount & $\$$ million, cumulative & \\
\hline & 1. Sovereign & $\$$ million, cumulative & \\
\hline & 2. Non-sovereign & $\$$ million, cumulative & \\
\hline & Disbursed amount & \$ million, cumulative & \\
\hline & 1. Sovereign & $\$$ million, cumulative & \\
\hline & 2. Non-sovereign & $\$$ million, cumulative & \\
\hline & Net foreign direct investment (FDI) inflows & $\%$ of GDP & \\
\hline & Sovereign debt risk rating & Letter rating & \\
\hline & Central government debt & $\%$ of GDP & \\
\hline & $\begin{array}{l}\text { CPIA quality of budgetary and financial } \\
\text { management rating }\end{array}$ & $1=$ low to $6=$ high & \\
\hline & Ease of Doing Business & & \\
\hline & Ease of doing business rank & Number & \\
\hline & Starting a business (rank) & Number & \\
\hline & Dealing with construction permits (rank) & Number & \\
\hline & Getting electricity (rank) & Number & \\
\hline & Registering property (rank) & Number & \\
\hline & Getting credit (rank) & Number & \\
\hline & Protecting minority investors (rank) & Number & \\
\hline & Paying taxes (rank) & Number & \\
\hline & Trading across borders (rank) & Number & \\
\hline & Enforcing contracts (rank) & Number & \\
\hline & Resolving insolvency (rank) & Number & \\
\hline & Corruption and Sustainable Development Index & & \\
\hline & Corruption Perceptions Index rank (out of 180) & Number & \\
\hline & Corruption Perceptions Index score (out of 100) & Number & \\
\hline & Sustainable Development Index rank & Number & \\
\hline & Sustainable Development Index score & Number & \\
\hline & $\begin{array}{l}\text { Cumulative Lending, Grant, and Technical } \\
\text { Assistance Commitments }\end{array}$ & & \\
\hline & Number of projects & Number & \\
\hline & Total lending & $\$$ million & \\
\hline & $\mathrm{GCl}$ infrastructure score & out of 7 & \\
\hline
\end{tabular}


Table A1.6 continued

\begin{tabular}{|c|c|c|c|}
\hline \multicolumn{2}{|r|}{ Supporting Indicators } & Units & Definition \\
\hline & EIU Infra-scope Index Score & & \\
\hline & PPP regulations score (out of 100) & Number & \\
\hline & PPP regulations rank & Number & \\
\hline & PPP institutions score (out of 100) & Number & \\
\hline & PPP institutions rank & Number & \\
\hline & PPP market maturity score (out of 100) & Number & \\
\hline & PPP market maturity rank & Number & \\
\hline & PPP financing score (out of 100) & Number & \\
\hline & PPP financing rank & Number & \\
\hline & Investment and business climate score (out of 100) & Number & \\
\hline & Investment and business climate rank & Number & \\
\hline \multirow{25}{*}{$\begin{array}{l}\text { Ease of Doing } \\
\text { Business }\end{array}$} & Score of starting a business & $(0-100)$ & \multirow{25}{*}{$\begin{array}{l}\text { Details on the } \\
\text { various Ease of } \\
\text { Doing Business } \\
\text { parameters for the } \\
\text { country based on } \\
\text { the World Bank's } \\
\text { Ease of Doing } \\
\text { Business publication }\end{array}$} \\
\hline & - Procedures & (number) & \\
\hline & - Time & (days) & \\
\hline & - Cost & (number) & \\
\hline & - Paid-in min. capital & (\% of income per capita) & \\
\hline & Score of dealing with construction permits & $(0-100)$ & \\
\hline & - Procedures & (number) & \\
\hline & - Time & (days) & \\
\hline & - Cost & (\% of warehouse value) & \\
\hline & - Building quality control index & $(0-15)$ & \\
\hline & Score of getting electricity & $(0-100)$ & \\
\hline & - Procedures & (number) & \\
\hline & - Time & (days) & \\
\hline & - Cost & (\% of income per capita) & \\
\hline & $\begin{array}{l}\text { - Reliability of supply and transparency of tariff } \\
\text { index }\end{array}$ & $(0-8)$ & \\
\hline & Score of registering property & $(0-100)$ & \\
\hline & - Procedures & (number) & \\
\hline & - Time & (days) & \\
\hline & - Cost & (\% of property value) & \\
\hline & - Quality of the land administration index & $(0-30)$ & \\
\hline & Score of getting credit & $(0-100)$ & \\
\hline & - Strength of legal rights index & $(0-12)$ & \\
\hline & - Depth of credit information index & $(0-8)$ & \\
\hline & - Credit registry coverage & (\% of adults) & \\
\hline & - Credit bureau coverage & (\% of adults) & \\
\hline
\end{tabular}


Table A1.6 continued

\begin{tabular}{|c|c|c|c|}
\hline Subcategory & Supporting Indicators & Units & Definition \\
\hline & Score of protecting minority investors & $(0-100)$ & \\
\hline & - Extent of disclosure index & $(0-10)$ & \\
\hline & - Extent of director liability index & $(0-10)$ & \\
\hline & - Ease of shareholder suits index & $(0-10)$ & \\
\hline & - Extent of shareholder rights index & $(0-6)$ & \\
\hline & - Extent of ownership and control index & $(0-7)$ & \\
\hline & - Extent of corporate transparency index & $(0-7)$ & \\
\hline & Score of paying taxes & $(0-100)$ & \\
\hline & - Payments & (number per year) & \\
\hline & - Time & (hours per year) & \\
\hline & - Total tax and contribution rate & (\% of profit) & \\
\hline & - Post-filing index & $(0-100)$ & \\
\hline & Score of trading across borders & $(0-100)$ & \\
\hline & Time to export & & \\
\hline & - Documentary compliance & (hours) & \\
\hline & - Border compliance & (hours) & \\
\hline & Cost to export & & \\
\hline & - Documentary compliance & (USD) & \\
\hline & - Border compliance & $($ USD) & \\
\hline & Time to export & & \\
\hline & - Documentary compliance & (hours) & \\
\hline & - Border compliance & (hours) & \\
\hline & Cost to export & & \\
\hline & - Documentary compliance & (USD) & \\
\hline & - Border compliance & (USD) & \\
\hline & Score of enforcing contracts & $(0-100)$ & \\
\hline & - Time & (days) & \\
\hline & - Cost & (\% of claim value) & \\
\hline & - Quality of judicial processes index & $(0-18)$ & \\
\hline & Score of resolving insolvency & $(0-100)$ & \\
\hline & - Recovery rate & (cents on the dollar) & \\
\hline & - Time & (years) & \\
\hline & - Cost & (\% of estate) & \\
\hline & - Outcome & $\begin{array}{c}\text { (0 as piecemeal sale and } 1 \\
\text { as going concern) }\end{array}$ & \\
\hline & - Strength of insolvency framework index & $(0-16)$ & \\
\hline
\end{tabular}




\section{Comment of Financial Indicators}

In regard to indicative loan terms presented in this publication, it should be noted that it is very difficult to generalize the loan terms as the data are dynamic. The data vary from one sector to another, and in a particular sector, the loan terms differ from one project to another depending on the project cash flows and the creditworthiness of the project sponsors. The loan terms are also driven by market forces, monetary policy, fiscal policy, and other macro-economic variables. Generally, international banks provide project finance in internationally convertible currency and the terms are broadly consistent across countries, given other risk factors are held constant, as country risk is the only risk factor. In general, some of the factors that determine pricing are

- exposure to market/revenue risk,

- exposure to foreign exchange risk,

- credibility of off-taker,

- credibility of sovereign,

- availability of export credit/multilateral support,

- "proven-ness" of sector and underlying technology, and

- financing market (such as global macroeconomic events) and regulations (i.e., Basel III).

It is understood in project finance that lenders take all securities including security over the "rights" of the concessionaire to operate the asset and collect revenue. The stability of the revenue stream is most important, and most international lenders will require a sovereign guarantee from the Ministry of Finance for the paying authority's obligations. In addition, from a commercial bank's perspective, such sovereign guarantee has to be further guaranteed/insured by export credit agencies and/or multilateral lending agencies.

In general, local banks lending in local currency will have less stringent requirements on a project; however, they will also offer a higher financing cost. From previous market sounding, local banks can generally cope with higher debt-equity ratios, lower debt-service coverage ratio, and no explicit sovereign guarantee where international lenders would require it. They can also cope with some level of revenue and fare risk where international banks demand a guaranteed offtake for greenfield projects. Also, very often banks have the appetite and capacity to finance public-private partnership (PPP) projects; however, the lack of well-prepared and structured projects limits the progress.

Capital markets are expected to play a major role in financing infrastructure PPPs, but are relatively underdeveloped in majority of the developing member countries (DMCs) covered. Capital markets have played a muted role in project financing in such DMCs. DMCs with a relatively matured PPP market and a relatively developed capital market have witnessed some PPPs issuing bonds and raising financing from capital markets. Institutional investors such as insurance companies and pension funds are restricted from taking exposure to PPP projects during construction period due to their internal investment norms and regulatory requirements to invest in investment grade projects and investment avenues, which majority of infrastructure PPPs do not attain during the construction period. Hence majority of such institutional investors take exposure to infrastructure PPPs during the operations period by buying out a part of the equity investment (as allowed by the PPP Agreement) of the project sponsors, or by retiring out bank financing for the project. 


\section{Comments on Data Sources}

The research was carried out using publicly available sources, including

- government websites, reports, and publications, including national government line ministries and government contracting agencies;

- annual reports of national government line ministries and government contracting agencies;

- applicable laws and regulations (where regulations were available only in the local language, unofficial translations were used);

- websites and annual reports of sector regulators;

- Asian Development Bank (ADB) reports and publications;

- online publications of other multilateral development agencies;

- industry publications and databases such as Inframation News and IJGlobal Project Finance \& Infrastructure Journal;

- publications and websites of reputable consultancy companies and law firms; and

- other publicly available reports, publications, and documents from authentic and globally acceptable sources.

Some of the widely used databases included

- World Bank Private Participation in Infrastructure (PPI) Database, https://ppi.worldbank.org/en/ppi;

- Inframation database https://www.inframationnews.com/;

- IJGlobal database, https://ijglobal.com/;

- PPP Knowledge Lab, https://pppknowledgelab.org/;

- the Economist Intelligence Unit (EIU) Infrascope Index, https://infrascope.eiu.com/;

- Global Infrastructure Hub, https://www.gihub.org/;

- Organisation for Economic Co-operation and Development (OECD), https://www.oecd.org/;

- TheGlobalEconomy.com, https://www.theglobaleconomy.com/;

- International Monetary Fund (IMF), https://data.imf.org/?sk=388dfa60-1d26-4ade-b505-a05a558d9a42;

- Doing Business, https://www.doingbusiness.org/;

- World Bank Public-Private-Partnership Legal Resource Center, https://ppp.worldbank.org/public-privatepartnership/;

- World Economic Forum, The Global Competitiveness Report, http://www3.weforum.org/docs/WEF_ TheGlobalCompetitivenessReport2019.pdf;

- Global Infrastructure Outlook, https://outlook.gihub.org/; and

- Trading Economics, https://tradingeconomics.com/. 
Some of the other major sources used included:

- ADB, Indonesia: Country Partnership Strategy (2016-2019), 2016, https://www.adb.org/documents/ indonesia-country-partnership-strategy-2016-2019;

- Asia-Pacific Economic Cooperation (APEC) Secretariat, APEC Policy Support Unit, October 2019, Peer Review and Capacity Building on APEC Infrastructure Development and Investment: Indonesia. https:// www.apec.org/Publications/2019/11/Peer-Review-and-Capacity-Building-on-APEC-InfrastructureDevelopment-and-Investment-Indonesia;

- Ministry of National Development Planning/National Development Planning Agency (BAPPENAS), Public-Private Partnership: Infrastructure Projects Plan in Indonesia 2019 (PPP Book 2019), 2019, https://www. infrapppworld.com/report/indonesia-ppp-book-2019;

- Website of BAPPENAS, https://www.bappenas.go.id/id/;

- Website of the Indonesia Infrastructure Guarantee Fund (IIGF) - https://ptpii.co.id/; and

- PPP guidance materials:

- World Bank, Benchmarking Infrastructure Development, https://bpp.worldbank.org/\#5;

- ADB, Stepping Up Investments for Growth Acceleration Program, https://www.adb.org/projects/ documents/ino-stepping-up-investments-for-growth-acceleration-program-subprogram2-rrp; and

- Melli Darsa \& Co, New Presidential Regulation Regarding Acceleration of the Implementation of Strategic National Projects (article), Lexology, 29 February 2016, https://www.lexology.com/library/detail. aspx?g=9a5beb25-2129-4281-85a6-69547055f0a5.

- https://ppp.gov.ph/wp-content/uploads/2020/01/PDMFS_200190128_REP_Revised-GuidelinesJanuary-2020.pdf

A detailed list of sources is provided in the References section of this publication.

In addition to the above-mentioned sources, the research for this report was informed by the internal knowledge of CRISIL Infrastructure Advisory, based on various ongoing and completed PPP consultancy assignments in Indonesia; public sector officials; the ADB team from the Office of Public-Private Partnership (OPPP); the ADB Resident Mission for Indonesia; consultants to the ADB Resident Mission in Indonesia; various government agencies; and contributing legal firms and commercial banks.

It should be noted that, as the research relied primarily on information reported in public sources that have not been verified by the authors and may not be accurate or contain all the required information, there is the risk of inaccuracy and incompleteness, depending on the reliability of sources and the validity of the information used.

For quantitative indicators relating to the number of projects, where there were gaps the total number of cases has been reported based on the limited information available. Therefore, reported numbers of projects in this publication may be an underestimate or overestimate the actual numbers.

Further, for various indicators, this publication captures information based on the provisions of the laws, regulations, policies, and government publications associated with the PPP legal, regulatory, policy, and institutional frameworks in the country. This publication does not provide details on the existing status regarding the adoption or application of such PPP laws, regulations, and policies, and the existing challenges being faced in such applications. 


\section{Appendix 2}

\section{Macroeconomic and Infrastructure Sector Indicators of Pakistan}

The critical macroeconomic and infrastructure sector indicators of Pakistan are summarized in Table A2. These indicators will facilitate awareness of the country's public-private partnership (PPP) landscape.

Table A2: Macroeconomic and Infrastructure Sector Indicators of Pakistan

\begin{tabular}{|c|c|c|}
\hline Parameter & Value & Unit \\
\hline Total population (no.) & 217.93 & million \\
\hline Average annual population growth rate & 3.0 & $\%$ \\
\hline Population density & 274.0 & $\begin{array}{c}\text { no. of persons per } \\
\mathrm{km}^{2}\end{array}$ \\
\hline Urban population & 36.38 & $\begin{array}{l}\% \text { of total } \\
\text { population }\end{array}$ \\
\hline Surface area & 796.1 & '000 km² \\
\hline Unemployment rate & 5.79 & $\%$ \\
\hline Proportion of population below $\$ 1.90$ purchasing power parity a day & 3.94 & $\%$ \\
\hline \multirow[t]{2}{*}{ Nominal GDP } & 283.31 & \$ billion \\
\hline & 3.29 & $\%$ \\
\hline Annual growth rate of GDP (2019) & 1.9 & $\%$ \\
\hline Annual growth rate of GDP (2020 forecast) & $(0.4)$ & $\%$ \\
\hline Annual growth rate of GDP (2021 forecast) & 2.0 & $\%$ \\
\hline GDP at purchasing power parity per capita & $5,520.00$ & $\$$ \\
\hline GDP at current market prices & 304.00 & \$ billion \\
\hline Gross fixed investment at current market prices & 14.2 & $\%$ of GDP \\
\hline Per capita GNI, Atlas Method & $1,590.00$ & $\$$ \\
\hline Inflation rate (2019) & 6.8 & $\%$ \\
\hline Inflation rate (2020 forecast) & 11.0 & $\%$ \\
\hline Inflation rate (2021 forecast) & $\ldots$ & $\%$ \\
\hline Current account (2019) & $(6.19)$ & $\%$ of GDP \\
\hline External trade, goods, value of imports, CIF (2018) & 201.11 & $\$$ billion \\
\hline External trade, goods, value of exports, FOB (2018) & 191.29 & \$ billion \\
\hline CPI \% change over 2018 & 10.578 & \% of CPI in 2018 \\
\hline
\end{tabular}


Table A2 continued

\begin{tabular}{|c|c|c|}
\hline Parameter & Value & Unit \\
\hline Real effective exchange rate & 97.064 & \\
\hline Investment in energy with private sector participation & $2,977.00$ & current $\$$ million \\
\hline Investment in transport with private sector participation & 240.00 & current $\$$ million \\
\hline Investment in water and sanitation with private sector participation & $\ldots$ & current $\$$ million \\
\hline LPI rank (Out of 167) & 122 & no. \\
\hline LPI score (Out of 5) & 2.42 & no. \\
\hline Customs rank (Out of 167) & 139 & no. \\
\hline Customs score (Out of 5) & 2.12 & no. \\
\hline Infrastructure rank (Out of 167) & 121 & no. \\
\hline Infrastructure score (Out of 5) & 2.2 & no. \\
\hline International shipments rank (Out of 167) & 97 & no. \\
\hline International shipments score (Out of 5) & 2.63 & no. \\
\hline Logistics competence rank (Out of 167) & 89 & no. \\
\hline Logistics competence score (Out of 5) & 2.59 & no. \\
\hline Tracking and tracing rank (Out of 167) & 136 & no. \\
\hline Tracking and tracing score (Out of 5) & 2.27 & no. \\
\hline Timeliness rank (Out of 167) & 136 & no. \\
\hline Timeliness score (Out of 5) & 2.66 & no. \\
\hline \multicolumn{3}{|l|}{ Structure of Output (\% of GDP at current producer | basic prices) } \\
\hline Agriculture & 24.0 & $\%$ \\
\hline Industry & 19.3 & $\%$ \\
\hline Services & 56.8 & $\%$ \\
\hline Consumer price index (national) & 3.9 & $\%$ annual change \\
\hline Producer price index & $\ldots$ & $\%$ annual change \\
\hline Wholesale price index (national) & 3.5 & $\%$ annual change \\
\hline Retail price index & $\ldots$ & $\%$ annual change \\
\hline Exchange rate (end of period) & 138.80 & local currency - \$ \\
\hline \multicolumn{3}{|l|}{ ADF Portfolio } \\
\hline Total number of loans & 15 & no. \\
\hline 1. Sovereign & $\ldots$ & no. \\
\hline 2. Nonsovereign & $\ldots$ & no. \\
\hline Net loan amount (cumulative) & $1,460.70$ & $\$$ million \\
\hline 1. Sovereign & $\ldots$ & $\$$ million \\
\hline 2. Nonsovereign & $\ldots$ & \$ million \\
\hline Disbursed amount (cumulative) & 675.80 & $\$$ million \\
\hline 1. Sovereign & $\ldots$ & $\$$ million \\
\hline 2. Nonsovereign & $\ldots$ & $\$$ million \\
\hline FDI inflows & 0.8 & $\%$ of GDP \\
\hline
\end{tabular}


Table A2 continued

\begin{tabular}{|c|c|c|}
\hline Parameter & Value & Unit \\
\hline Sovereign debt risk rating & 59.0 & letter rating \\
\hline Central government debt & 66.5 & $\%$ of GDP \\
\hline CPIA quality of budgetary and financial management rating & 3.5 & 1=low to $6=$ high \\
\hline \multicolumn{3}{|l|}{ Ease of Doing Business (Out of 190) } \\
\hline Ease of doing business rank & 108 & no. \\
\hline Starting a business rank & 72 & no. \\
\hline Dealing with construction permits rank & 112 & no. \\
\hline Getting electricity rank & 123 & no. \\
\hline Registering property rank & 151 & no. \\
\hline Getting credit rank & 119 & no. \\
\hline Protecting minority investors rank & 28 & no. \\
\hline Paying taxes rank & 161 & no. \\
\hline Trading across borders rank & 111 & no. \\
\hline Enforcing contracts rank & 156 & no. \\
\hline Resolving insolvency rank & 58 & no. \\
\hline \multicolumn{3}{|l|}{ Corruption and Sustainable Development Index } \\
\hline Corruption Perceptions Index rank (out of 180) & 120 & no. \\
\hline Corruption Perceptions Index score (out of 100) & 32.0 & no. \\
\hline Sustainable Development Index (out of 193) & 134 & no. \\
\hline Sustainable Development Index score (out of 100) & 56.17 & no. \\
\hline \multicolumn{3}{|c|}{ Cumulative Lending, Grant, and Technical Assistance Commitments } \\
\hline No. of projects & 1,570 & no. \\
\hline Total lending & $68,790.00$ & $\$$ million \\
\hline $\mathrm{GCl}$ infrastructure score (out of 7) & 3.0 & no. \\
\hline \multicolumn{3}{|l|}{ EIU Infra scope Index Score } \\
\hline PPP regulations score (out of 100) & 47.0 & no. \\
\hline PPP regulations rank (Out of 19) & 17 & no. \\
\hline PPP institutions score (out of 100) & 88.0 & no. \\
\hline PPP institutions rank (Out of 19) & 7 & no. \\
\hline PPP market maturity score (out of 100) & 73.0 & no. \\
\hline PPP market maturity rank (Out of 19) & 2 & no. \\
\hline PPP financing score (out of 100) & 37.0 & no. \\
\hline
\end{tabular}


Table A2 continued

\begin{tabular}{|l|r|c|}
\hline Parameter & Value & Unit \\
\hline PPP financing rank (Out of 19) & 12 & no. \\
\hline Investment and business climate score (out of 100) & 55.0 & no. \\
\hline Investment and business climate rank (Out of 19) & 18 & no. \\
\hline
\end{tabular}

... = data not available; $\$$ = United States dollar; $\mathrm{ADF}=$ Asian Development Fund; $\mathrm{CIF}=$ cost, insurance, and freight; $\mathrm{CPI}=\mathrm{consumer}$ price index; $\mathrm{CPIA}=$ country policy and institutional assessment; EIU = Economist Intelligence Unit; FDI = foreign direct investment; $\mathrm{FOB}=$ free on board; $\mathrm{GCl}$ = global competitive index; $\mathrm{GDP}=$ gross domestic product; $\mathrm{GNI}=$ gross national income; $\mathrm{km}^{2}=\mathrm{square}$ kilometer; $\mathrm{LPI}=$ logistics performance index; PPP = public-private partnership.

Sources: Asian Development Bank (ADB). 2015. Country Partnership Strategy: Pakistan, 2015-2019. Manila. https://www.adb.org/ sites/default/files/institutional-document/171824/cps-pak-2015-2019.pdf; ADB. 2019. Key Indicators for Asia and Pacific 2019. Manila. https://www.adb.org/publications/key-indicators-asia-and-pacific-2019; ADB. 2020. Basic Statistics 2020. Manila. https://www.adb. org/publications/basic-statistics-2020; ADB. Data Library. Cumulative Lending, Grant, and Technical Assistance Commitments. https://data.adb.org/dataset/cumulative-lending-grant-and-technical-assistance-commitments (accessed 18 September 2020); ADB. GDP Growth in Asia and the Pacific, Asian Development Outlook (ADO). https://data.adb.org/dataset/gdp-growth-asia-andpacific-asian-development-outlook (accessed 18 September 2020); International Monetary Fund (IMF). Exchange Rate Selected Indicators. Pakistan. https://data.imf.org/regular.aspx?key=61545850 (accessed 18 September 2020); IMF. IMF Data. Access to Macroeconomic and Financial Data. Pakistan. https://data.imf.org/?sk=85b51b5a-b74f-473a-be16-49f1786949b3 (accessed 18 September 2020); The Economist Intelligence Unit. Infrascope 2018: Pakistan Country Profile. https://infrascope.eiu.com (accessed 18 September 2020); Transparency International. Countries: Pakistan. https://www.transparency.org/en/countries/pakistan\# (accessed 18 September 2020); World Bank. Doing Business: Ease of Doing Business in Pakistan. https://www.doingbusiness.org/en/ data/exploreeconomies/pakistan (accessed 18 September 2020); World Bank. LPI Global Rankings 2018. https://lpi.worldbank.org/ international/global?sort=asc\&order=LPI\%20Score\#datatable (accessed 18 September 2020); and World Bank. PPP Knowledge Lab. Pakistan. https://pppknowledgelab.org/countries/pakistan (accessed 18 September 2020).

\section{Comments on Data Sources}

The research was carried out using publicly available sources, including

- government websites, reports, and publications, including national government line ministries and government contracting agencies;

- annual reports of national government line ministries and government contracting agencies;

- applicable laws and regulations (where regulations were available only in the local language, unofficial translations were used);

- websites and annual reports of sector regulators;

- Asian Development Bank (ADB) reports and publications;

- online publications of other multilateral development agencies;

- industry publications and databases such as Inframation News and IJGlobal Project Finance \& Infrastructure Journal;

- publications and websites of reputable consultancy companies and law firms; and

- other publicly available reports, publications, and documents from authentic and globally acceptable sources.

Some of the widely used databases included

- World Bank Private Participation in Infrastructure (PPI) Database, https://ppi.worldbank.org/en/ppi;

- Inframation database https://www.inframationnews.com/;

- PPP Knowledge Lab, https://pppknowledgelab.org/countries/pakistan; 
- The Economist Intelligence Unit (EIU) Infrascope Index, https://infrascope.eiu.com/;

- TheGlobalEconomy.com, https://www.theglobaleconomy.com/;

- International Monetary Fund (IMF), https://data.imf.org/?sk=85b51b5a-b74f-473a-be16-49f1786949b3;

- Doing Business, https://www.doingbusiness.org/;

- World Bank Public-Private-Partnership Legal Resource Center, https://ppp.worldbank.org/publicprivatepartnership/;

- World Economic Forum, The Global Competitiveness Report, http://www3.weforum.org/docs/WEF_ TheGlobalCompetitivenessReport2019.pdf; and

- Trading Economics, https://tradingeconomics.com/.

Some of the other major sources used included

- ADB, Pakistan: Country Partnership Strategy (2015-2019), 2015, https://www.adb.org/sites/default/files/ institutional-document/171824/cps-pak-2015-2019.pdf;

- Website of Public Private Partnership Authority, http://pppa.gov.pk/;

- ADB, Public-Private Partnership Monitor. Second Edition, https:/www.adb.org/sites/default/files/ publication/509426/ppp-monitor-second-edition.pdf;

- Commonwealth Local Government Forum. The Local Government System in Pakistan, www.clgforg.uk/pakistan;

- List of laws and regulations

- Pakistan PPP Policy 2010, http://www.pppa.gov.pk/prod_img/PPP\%20Policy\%20FINAL\%2014-May2010.pdf; and

- Public Private Partnership Authority (Amendment) Act, 2021. Islamabad. http://www.senate.gov.pk/ uploads/documents/1612419098_271.pdf.

- World Bank, Benchmarking Infrastructure Development, https://bpp.worldbank.org/\#5.

A detailed list of sources is provided in the References section of this publication.

In addition to the abovementioned sources, the research for this report was informed by the internal knowledge of CRISIL Infrastructure Advisory, public sector officials, the ADB team from the Office of Public-Private Partnership (OPPP), the ADB Resident Mission for Pakistan, consultants to the ADB Resident Mission in Pakistan, various government agencies, and contributing legal firms and commercial banks. It should be noted that, as the research relied primarily on information reported in public sources that have not been verified by the authors and may not be accurate or contain all the required information, there is the risk of inaccuracy and incompleteness, depending on the reliability of sources and the validity of the information used.

For quantitative indicators relating to the number of projects, where there were gaps, the total number of cases has been reported based on the limited information available. Therefore, reported numbers of projects in this publication may be an underestimate or overestimate the actual numbers.

Further, for various indicators, this publication captures information based on the provisions of the laws, regulations, policies, and government publications associated with the PPP legal, regulatory, policy, and institutional frameworks in the country. This publication does not provide details on the existing status regarding the adoption or application of such PPP laws, regulations, and policies, and the existing challenges being faced in such applications. 


\section{Appendix 3}

\section{World Bank's Ease of Doing Business Parameters for Pakistan}

Table A3.1: Pakistan Basic Country Profile

\begin{tabular}{|c|c|c|c|c|}
\hline \multirow{4}{*}{$\begin{array}{l}\text { Ease of Doing Business } \\
\text { in Pakistan }\end{array}$} & Region & South Asia & \multirow{4}{*}{$\begin{array}{l}\text { Doing Business } \\
\text { Rank: } 108\end{array}$} & \multirow{4}{*}{$\begin{array}{l}\text { Doing Business } \\
\text { Score: } 61.0\end{array}$} \\
\hline & Income Category & Lower middle income & & \\
\hline & Population & $222,704,447^{a}$ & & \\
\hline & City Covered & Karachi, Lahore & & \\
\hline
\end{tabular}

a Worldometer. Pakistan Population. https://www.worldometers.info/world-population/pakistan-population/ (accessed 6 December 2020).

\section{Figure A3.1: Rankings on Doing Business in Pakistan by Categories, 2020}

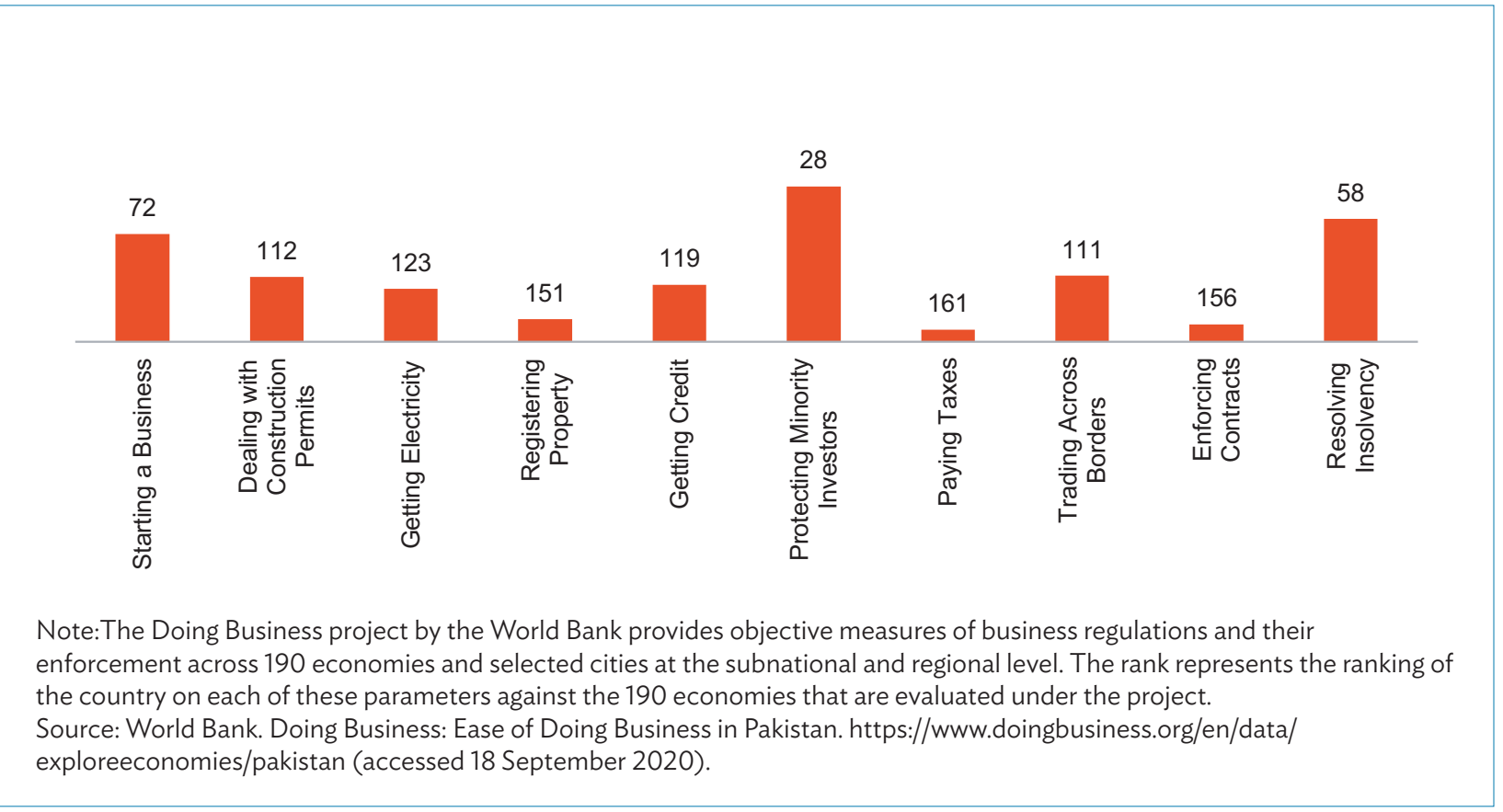


Figure A3.2: Scoring on Doing Business in Pakistan by Categories, 2020

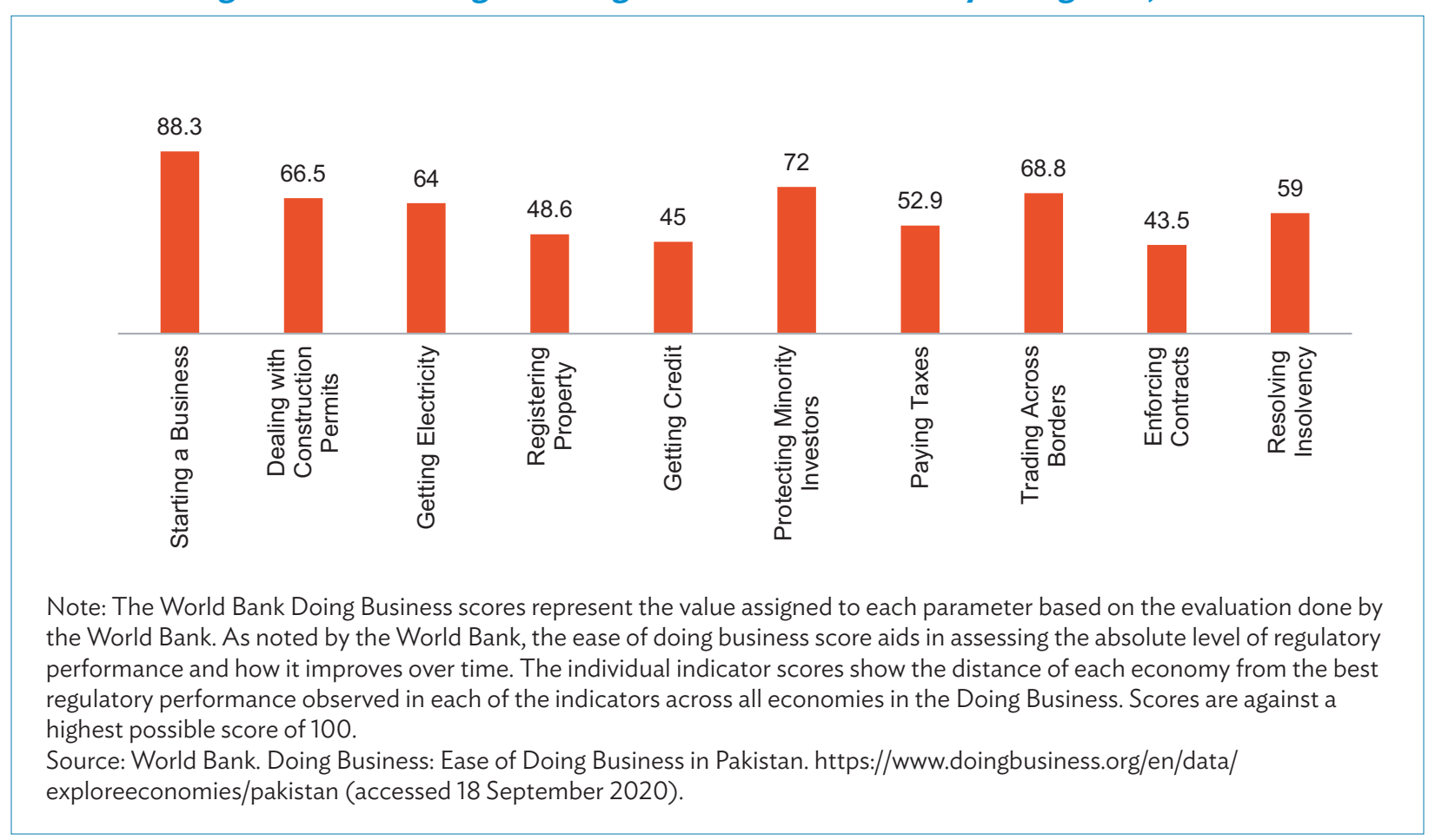

Table A3.2: Scores on Doing Business in Pakistan, by Categories and Subcategories

\begin{tabular}{|c|c|c|c|c|c|c|c|}
\hline $\begin{array}{l}\text { Starting a Business } \\
\text { (rank) }\end{array}$ & 72 & $\begin{array}{l}\text { Dealing with } \\
\text { Construction } \\
\text { Permits (rank) }\end{array}$ & 112 & $\begin{array}{l}\text { Getting Electricity } \\
\text { (rank) }\end{array}$ & 123 & $\begin{array}{l}\text { Registering } \\
\text { Property } \\
\text { (rank) }\end{array}$ & 151 \\
\hline $\begin{array}{l}\text { Score of starting a } \\
\text { business }(0-100)\end{array}$ & 89.3 & $\begin{array}{l}\text { Score of dealing } \\
\text { with construction } \\
\text { permits }(0-100)\end{array}$ & 66.5 & $\begin{array}{l}\text { Score of getting } \\
\text { electricity }(0-100)\end{array}$ & 64.0 & $\begin{array}{l}\text { Score of registering } \\
\text { property }(0-100)\end{array}$ & 48.6 \\
\hline $\begin{array}{l}\text { Procedures } \\
\text { (number) }\end{array}$ & 5 & $\begin{array}{l}\text { Procedures } \\
\text { (number) }\end{array}$ & 17 & $\begin{array}{l}\text { Procedures } \\
\text { (number) }\end{array}$ & 6 & $\begin{array}{l}\text { Procedures } \\
\text { (number) }\end{array}$ & 8 \\
\hline Time (days) & 16.5 & Time (days) & 125 & Time (days) & 113 & Time (days) & 105 \\
\hline Cost (number) & 6.7 & $\begin{array}{l}\text { Cost ( } \% \text { of } \\
\text { warehouse value) }\end{array}$ & 8.8 & $\begin{array}{l}\text { Cost (\% of income } \\
\text { per capita) }\end{array}$ & $1,234.5$ & $\begin{array}{l}\text { Cost ( } \% \text { of property } \\
\text { value) }\end{array}$ & 4.2 \\
\hline $\begin{array}{l}\text { Paid-in minimum } \\
\text { capital (\% of income } \\
\text { per capita) }\end{array}$ & 0 & $\begin{array}{l}\text { Building quality } \\
\text { control index (0-15) }\end{array}$ & 13.0 & $\begin{array}{l}\text { Reliability of supply } \\
\text { and transparency of } \\
\text { tariff index }(0-8)\end{array}$ & 5 & $\begin{array}{l}\text { Quality of the land } \\
\text { administration index } \\
(0-30)\end{array}$ & 9.8 \\
\hline
\end{tabular}


Table A3.2 continued

\begin{tabular}{|c|c|c|c|c|c|}
\hline $\begin{array}{l}\text { Getting Credit } \\
\text { (rank) }\end{array}$ & 119 & $\begin{array}{l}\text { Protecting Minority } \\
\text { Investors (rank) }\end{array}$ & 28.0 & $\begin{array}{l}\text { Paying Taxes } \\
\text { (rank) }\end{array}$ & 161 \\
\hline $\begin{array}{l}\text { Score of getting credit } \\
(0-100)\end{array}$ & 45.0 & $\begin{array}{l}\text { Score of protecting minority } \\
\text { investors }(0-100)\end{array}$ & 72.0 & $\begin{array}{l}\text { Score of paying taxes } \\
(0-100)\end{array}$ & 52.9 \\
\hline $\begin{array}{l}\text { Strength of legal rights index } \\
(0-12)\end{array}$ & 2 & $\begin{array}{l}\text { Extent of disclosure index } \\
(0-10)\end{array}$ & 6.0 & Payments (number per year) & 34 \\
\hline $\begin{array}{l}\text { Depth of credit information } \\
\text { index }(0-8)\end{array}$ & 7 & $\begin{array}{l}\text { Extent of director liability } \\
\text { index }(0-10)\end{array}$ & 7.0 & Time (hours per year) & 283 \\
\hline $\begin{array}{l}\text { Credit registry coverage } \\
\text { (\% of adults) }\end{array}$ & 11.7 & $\begin{array}{l}\text { Ease of shareholder suits } \\
\text { index }(0-10)\end{array}$ & 6.0 & $\begin{array}{l}\text { Total tax and contribution } \\
\text { rate (\% of profit) }\end{array}$ & 33.9 \\
\hline \multirow[t]{3}{*}{$\begin{array}{l}\text { Credit bureau coverage } \\
\text { ( } \% \text { of adults) }\end{array}$} & 6.7 & $\begin{array}{l}\text { Extent of shareholder rights } \\
\text { index }(0-6)\end{array}$ & 5.0 & Post filing index (0-100) & 10.5 \\
\hline & & $\begin{array}{l}\text { Extent of ownership and } \\
\text { control index }(0-7)\end{array}$ & 7.0 & & \\
\hline & & $\begin{array}{l}\text { Extent of corporate } \\
\text { transparency index }(0-7)\end{array}$ & 5.0 & & \\
\hline
\end{tabular}

\begin{tabular}{|c|c|c|c|c|c|}
\hline $\begin{array}{l}\text { Trading across Borders } \\
\text { (rank) }\end{array}$ & 111 & $\begin{array}{l}\text { Enforcing Contracts } \\
\text { (rank) }\end{array}$ & 156 & $\begin{array}{l}\text { Resolving Insolvency } \\
\text { (rank) }\end{array}$ & 58 \\
\hline $\begin{array}{l}\text { Score of trading across } \\
\text { borders }(0-100)\end{array}$ & 68.8 & $\begin{array}{l}\text { Score of enforcing contracts } \\
(0-100)\end{array}$ & 43.5 & $\begin{array}{l}\text { Score of resolving } \\
\text { insolvency }(0-100)\end{array}$ & 59.0 \\
\hline Time to export & & Time (days) & 1,071 & $\begin{array}{l}\text { Recovery rate (cents on the } \\
\text { dollar) }\end{array}$ & 42.8 \\
\hline $\begin{array}{l}\text { Documentary compliance } \\
\text { (hours) }\end{array}$ & 55 & Cost ( $\%$ of claim value) & 20.5 & Time (years) & 2.6 \\
\hline Border compliance (hours) & 58 & $\begin{array}{l}\text { Quality of judicial processes } \\
\text { index } \\
(0-18)\end{array}$ & 5.7 & Cost (\% of estate) & 4.0 \\
\hline Cost to export & & & & $\begin{array}{l}\text { Outcome ( } 0 \text { as piecemeal } \\
\text { sale and } 1 \text { as going concern) }\end{array}$ & 0 \\
\hline $\begin{array}{l}\text { Documentary compliance } \\
(\$)\end{array}$ & 118 & & & $\begin{array}{l}\text { Strength of insolvency } \\
\text { framework index }(0-16)\end{array}$ & 11.5 \\
\hline Border compliance $(\$)$ & 288 & & & & \\
\hline \multicolumn{6}{|l|}{ Time to export } \\
\hline $\begin{array}{l}\text { Documentary compliance } \\
\text { (hours) }\end{array}$ & 96 & & & & \\
\hline Border compliance (hours) & 120 & & & & \\
\hline \multicolumn{6}{|l|}{ Cost to export } \\
\hline $\begin{array}{l}\text { Documentary compliance } \\
(\$)\end{array}$ & 130 & & & & \\
\hline Border compliance $(\$)$ & 287 & & & & \\
\hline
\end{tabular}

Source: World Bank. Doing Business: Ease of Doing Business in Pakistan. https://www.doingbusiness.org/en/data/exploreeconomies/ pakistan (accessed 18 September 2020). 


\section{Appendix 4}

\section{Assessment of Public Financial Management System in Pakistan, 2012}

The latest assessment of the Public Financial Management System (PFMS), based on the Public Expenditure and Financial Accountability (PEFA) framework of 2012, states that Pakistan has an overall rating of $A$ (on a four-point rating scale, with $A$ as the best and $D$ as the worst) in terms of the country's transparency in intergovernmental fiscal relations (Table A4.1). ${ }^{1}$

\section{Table A4.1: Public Expenditure and Financial Accountability Assessment of Pakistan's Public Financial Management System, 2012}

\begin{tabular}{|c|c|c|}
\hline Parameter/Subparameter & Score & Justification for Score \\
\hline $\begin{array}{l}\text { Transfers to subnational } \\
\text { governments }\end{array}$ & $A$ & $\begin{array}{l}\text { A structured rule-based allocation system governs the allocations to and among } \\
\text { subnational governments in Pakistan under the direction of the National Finance } \\
\text { Commission (NFC). The NFC award is the distribution of financial resources among } \\
\text { the provinces of Pakistan by the federal government on an annual basis. Certain } \\
\text { types of taxes collected by the federal government are pooled and redistributed } \\
\text { according to the NFC formula. Allocations from shares in federal taxes are made } \\
\text { through a divisible pool, with shares being determined by the NFC award. }\end{array}$ \\
\hline $\begin{array}{l}\text { System for allocating } \\
\text { transfers }\end{array}$ & A & $\begin{array}{l}\text { Based on the decision taken during the } 7 \text { th NFC held in December } 2009 \text {, the } \\
\text { provincial share of the divisible pool would increase from } 47.5 \% \text { to } 56.0 \% \text { in the } \\
\text { first fiscal year (FY2010) of the NFC award, and } 57.5 \% \text { in the remaining years. }\end{array}$ \\
\hline $\begin{array}{l}\text { Timeliness of information } \\
\text { on transfers }\end{array}$ & B & $\begin{array}{l}\text { Provincial governments follow the same budgeting calendar as the federal } \\
\text { government (i.e., Budget Call Circular)-issued in November/December each year } \\
\text { and budgets are to be finalized in May/June. An indicative amount is given at the } \\
\text { start of the budget making process and the final allocations are communicated to } \\
\text { the provinces by early June, once the federal budget is prepared. }\end{array}$ \\
\hline $\begin{array}{l}\text { Extent of collection and } \\
\text { reporting of consolidated } \\
\text { fiscal data for general } \\
\text { government }\end{array}$ & A & \\
\hline
\end{tabular}

Note: Scores are based on a four-point rating scale, with $A$ as the best and $D$ as the worst.

Source: Public Expenditure and Financial Accountability. 2012. Pakistan Federal Government: Public Financial Management and Accountability Assessment. Report No. 69185-PK. Islamabad: World Bank Pakistan. https://openknowledge.worldbank.org/ handle/10986/26816.

1 PEFA. 2012. Pakistan Federal Government: Public Financial Management and Accountability Assessment. Report No. 69185-PK. Islamabad: World Bank Pakistan. https://openknowledge.worldbank.org/handle/10986/26816. 
Basic parameters for assessing the budgetary allocation and transfers from the central to the local governments are presented in Table A4.2.

Table A4.2: Budgetary Transfers from the National Government to the Subnational Governments

\begin{tabular}{|l|c|c|}
\hline Parameter & Value & Unit \\
\hline Central government transfers to subnational governments & $\ldots$ & of the GDP \\
\hline Actual budgetary allocation to subnational governments from national government & $\ldots$ & $\%$ of total expenditure \\
\hline Deviation of actual against the budgeted transfers to subnational governments & $\ldots$ & $\%$ of budgeted transfers \\
\hline
\end{tabular}

$\ldots=$ data not available, GDP = gross domestic product.

Source: Public Expenditure and Financial Accountability. 2012. Pakistan Federal Government: Public Financial Management and Accountability Assessment. Report No. 69185-PK. Islamabad: World Bank Pakistan. https://openknowledge.worldbank.org/ handle/10986/26816. 


\section{References}

Asian Development Bank (ADB). 2015. Country Partnership Strategy: Pakistan, 2015-2019. Manila. https://www. adb.org/sites/default/files/institutional-document/171824/cps-pak-2015-2019.pdf.

-_- 2019a. Key Indicators for Asia and Pacific 2019. Manila. https://www.adb.org/publications/key-indicatorsasia-and-pacific-2019.

-_- 2019b. Public-Private Partnership Monitor. Second Edition. Manila. https://www.adb.org/sites/default/files/ publication/509426/ppp-monitor-second-edition.pdf.

_-_. 2020. Basic Statistics 2020. Manila. https://www.adb.org/publications/basic-statistics-2020.

-_- Data Library. Cumulative Lending, Grant, and Technical Assistance Commitments. https://data.adb.org/ dataset/cumulative-lending-grant-and-technical-assistance-commitments.

- - - GDP Growth in Asia and the Pacific, Asian Development Outlook (ADO). https://data.adb.org/dataset/ gdp-growth-asia-and-pacific-asian-development-outlook.

Axis Law Chambers. 2021. A General Introduction to Public-Private Partnerships in Pakistan. Lexology. 8 April. https://www.lexology.com/library/detail.aspx?g=478ca4ad-651c-4c46-8cb8-067304ba18a8.

Bhandari Naqvi Riaz. 2020. First-Step Analysis: Arbitration in Pakistan. Lexology. 24 February. https://www. lexology.com/library/detail.aspx?g=fb17baa0-25f4-4416-ae1e-32fadc655bda.

BioEnergy Consult. 2020. Solid Waste Management in Pakistan. https://www.bioenergyconsult.com/solid-wastemanagement-in-pakistan/ (accessed 1 September 2020).

G. Bryan, A. Cheema, A. Jamal, A. Khan, A. Liaqat, and G. Padro i Miquel. 2019. State Capacity in Punjab's Local Governments: Benchmarking Existing Deficits. S-37433-PAK-2. London: International Growth Centre. https://www.theigc.org/wp-content/uploads/2020/08/Bryan-et-al-2019-Final-report_update.pdf.

City Population. Airports. https://www.citypopulation.de/en/world/bymap/airports.html (accessed 2 December 2020).

Commonwealth Local Government Forum. 2018. The Local Government System in Pakistan: Country Profile 2017-18. London. https://www.clgf.org.uk/default/assets/File/Country_profiles/Pakistan.pdf.

Government of Pakistan. 2020. PPP Projects: Concepts and Status. Presentation prepared by the Ministry of Railways. Islamabad. August.

Government of Pakistan, Aviation Division. http://aviation.gov.pk/Overview. 
Government of Pakistan, Finance Division. 2020. Pakistan Economic Survey 2019-2020. Islamabad. https://pc.gov. pk/uploads/cpec/PES_2019_20.pdf.

Government of Pakistan, Ministry of Communications, National Highway Authority, Road Asset Management System Section. 2010. NHA Tolling Policy. Islamabad. http://nha.gov.pk/wp-content/uploads/2016/04/SOPfor-NHA-Tolling-Policy.docx.

Government of Pakistan, Ministry of Energy (Power Division), Alternative Energy Development Board (AEDB). http://www.aedb.org/\#.

———. E-Library. https://www.aedb.org/ju-elibrary/ (accessed 1 September 2020).

-_ 2019. Power Policy: Alternative and Renewable Energy. Islamabad. http://www.aedb.org/images/ARE_ Policy_2019_AEDB.pdf.

Government of Pakistan, Ministry of Energy (Power Division), Private Power and Infrastructure Board (PPIB). https://www.ppib.gov.pk/.

- - - Upcoming IPPs (as of 4 December 2020). https://www.ppib.gov.pk/upcomming_ipps.html (accessed 15 December 2020).

Government of Pakistan, Ministry of Finance, and Infrastructure Project Development Facility. 2007. Project Preparation/Feasibility Guidelines for PPP Projects. Islamabad. https://library.pppknowledgelab.org/ documents/2273/download.

Government of Pakistan, Ministry of Information Technology and Telecommunications. 2018. Digital Pakistan Policy. Islamabad. http://moib.gov.pk/Downloads/Policy/DIGITAL_PAKISTAN_POLICY(22-05-2018).pdf.

Government of Pakistan, Ministry of Maritime Affairs. https://moma.gov.pk/Detail/NzlxMTIzM2EtMjQw OCOOMjUyLTIhOTctMTViNzVkYzA2Nmly.

——_. 2017. Year Book 2016-2017. Islamabad. https://moma.gov.pk/Sitelmage/Misc/files/YB_2016-17.pdf.

Government of Pakistan, Ministry of Planning, Development and Reform (Planning Commission). 2015. Pakistan 2025: One Nation, One Vision. Islamabad. https://www.pc.gov.pk/uploads/vision2025/Pakistan-Vision-2025. pdf.

Government of Pakistan, Ministry of Planning, Development and Special Initiatives (Planning Commission). 2020. Public Sector Development Programme 2020-21. Islamabad. https:/www.pc.gov.pk/uploads/archives/ PSDP_2020-21.pdf.

Government of Pakistan, Ministry of Railways. 2020. PPP Projects. Islamabad. http://www.railways.gov.pk/ Sitelmage/Misc/files/PPP\%20Project\%20List.pdf.

Government of Pakistan, Ministry of Water Resources. 2018. National Water Policy 2018. Islamabad. http://mowr. gov.pk/wp-content/uploads/2018/06/National-Water-policy-2018-2.pdf.

Government of Pakistan, National Electric Power Regulatory Authority (NEPRA). 2009. Tariff Determination for a Sample Thermal Electric Power IPP Project. AES Pakistan (Pvt.) Ltd. https://nepra.org.pk/tariff/Tariff/IPPs/ AES\%20PakGen/TRF-134\%20AES\%20-\%202009\%20Determination.PDF.

—_- 2013. Tariff Determination for a Sample Hydel Power Plant IPP Project. Blue Star Energy (Pvt.) Ltd. https:// nepra.org.pk/tariff/Tariff/IPPs/Blue\%20Star\%20Energy/2013/TRF-201\%20BSEL\%20Determination\%20 Dt.02-01-2013\%2044-46.PDF. 
. 2016. Tariff Determination for a Sample Solar IPP Project. AJ Power (Private) Limited. https://nepra.org. pk/tariff/Tariff/IPPs/002\%20Solar\%20IPPs/AJPPL/Revised\%20Decision\%20of\%20AJ\%20Power\%20 Upfront\%20Tariff\%20Solar.PDF.

- - 2017. Tariff Determination for a Sample Bagasse-based Co-generation Power IPP Project. Alliance Power (Pvt.) Ltd. https://nepra.org.pk/tariff/Tariff/IPPs/05\%20Bioenergy/Alliance\%20Sugar\%20Mills/TRF393\%20APPL\%20Upfront\%20Bagasse\%2011-09-2017\%2015256-58.PDF.

- 2018. Tariff Determination for a Sample Waste-to-Energy IPP Project. Lahore Xingzhong Renewable Energy Company (Pvt.) Ltd. https://nepra.org.pk/tariff/Tariff/IPPs/05\%20Bioenergy/Lahore\%20 Xingzhong\%20Renewable\%20Energy\%20Company/TRF-445\%20LXREC\%20\%2020-07-2018\%20 11883-85.PDF.

_- - 2020. Tariff Determination for a Sample Wind Power IPP Project. Act 2 Wind Power (Pvt.) Ltd. https:// nepra.org.pk/tariff/Tariff/IPPs/000\%20IPPs\%20Wind/Act\%202\%20Wind\%20Pvt\%20Limited/2020/TRF489\%20AWPL\%20Modification\%2023-07-2020\%2018810-12.PDF.

Government of Pakistan, National Highway Authority (NHA). https://nha.gov.pk/ettmmap/highways-2/ (accessed 1 September 2020).

- - List of PPP Projects under Implementation. https://nha.gov.pk/wp-content/uploads/2016/04/List-ofPPP-Project-as-of-10-10-2018.pdf (accessed 1 September 2020).

-C-. Upcoming PPP Projects. Islamabad. https://nha.gov.pk/wp-content/uploads/2016/04/List-of-UpcomingPPP-Projects-as-Per-PSDP-2019-20.pdf (accessed 1 September 2020).

Government of Pakistan, National Transmission and Despatch Company Limited. Future Projects. http://ntdc. gov.pk/casa (accessed 1 September 2020).

Government of Pakistan, Pakistan Civil Aviation Authority. 2019. National Aviation Policy 2019. Karachi. https:// www.caapakistan.com.pk/upload/AT/NAP-2019.pdf.

Government of Pakistan, Pakistan Environmental Protection Agency (formerly under the defunct Ministry of Environment, and now under the Ministry of Climate Change). 2005. Draft Guidelines for Solid Waste Management. Islamabad. http://www.environment.gov.pk/images/provincialsepasguidelines/ SWMGLinesDraft.pdf.

- - - n.d. Brief on Solid Waste Management in Pakistan. Islamabad. http://www.environment.gov.pk/images/ environmentalissues/BriefSWMPak.pdf.

Government of Pakistan, Public Private Partnership Authority (PPPA). 2010. Pakistan Policy on Public Private Partnerships: Private Participation in Infrastructure for Better Public Services. Islamabad. http://www.lcwu.edu. pk/ocd/cfiles/City\%20and\%20Regional\%20Planning/CRP-45/Lec5PPPPolicyFINAL14-May-2010.pdf.

- - . 2018. PPPA Newsletter. 1 (1). November. Islamabad. https://www.pppa.gov.pk/Sitelmage/Misc/files/ NewsLetters/Newsletter-2\%20Nov\%202018\%20(Vol\%201).pdf.

- - 2020. Public Private Partnership Authority (Amendment) Act 2021. Islamabad. http://www.senate.gov.pk/ uploads/documents/1612419098_271.pdf.

__—. Pipeline Projects. http://pppa.gov.pk/pproj.php (accessed 22 September 2020) 
Government of Pakistan, Public Procurement Regulatory Authority (PPRA). 2015. PPRA Procurement Code. 4th ed. Islamabad. https://www.ppra.org.pk/doc/code4.pdf.

- - 2020. Public Procurement Regulatory Authority (Amendment) Ordinance 2020. Islamabad. https://ppra.org. pk/doc/ordinance2020.pdf.

Government of Pakistan, Water and Power Development Authority (WAPDA). About Us-Present Setup. http://www.wapda.gov.pk/index.php/about-us/present-setup.

-—-. Hydro Power Projects-Future. http://www.wapda.gov.pk/index.php/duber-khwar-hydropower-menu-2/ itemlist/category/34-future (accessed 10 September 2020).

International Growth Centre. 2019. State Capacity in Punjab's Local Governments. Islamabad. https://www.theigc. org/wp-content/uploads/2020/08/Bryan-et-al-2019-Final-report_update.pdf.

International Monetary Fund (IMF). https://data.imf.org/?sk=85b51b5a-b74f-473a-be16-49f1786949b3.

. Exchange Rate Selected Indicators. https://data.imf.org/regular.aspx?key=61545850.

J. Nasir. 2020. Govt to Introduce PSDP Plus Program with a Rs. 5.2 Trillion Investment. Pro Pakistani. https:// propakistani.pk/2019/12/16/govt-to-introduce-psdp-plus-program-with-a-rs-5-2-trillion-investment/.

Nasir Law Associates. 2002. The Railway Regulatory Authority Ordinance, 2002. Islamabad. http://nasirlawsite. com/laws/rrao.htm.

Pakistan Credit Rating Agency Limited (PACRA). http://pacra.pk/about_us.

-_- 2020. Power Sector Report on Power and Energy Generation. Islamabad. https://pacra.pk/research.

Pakistan Institute of Legislative Development and Transparency. 2019. Briefing Paper: Comparative Analysis of Local Government Laws in Pakistan. Islamabad. https://pildat.org/wp-content/uploads/2019/04/ ComparativeAnalysisofLocalGovernmentLawsinPakistan.pdf.

Pakistan Water Supply and Sanitation Sector Vol II, https://hudphed.punjab.gov.pk/system/files/8\%28b\%29Pakistan\%20Rural-Vol\%20II_v3\%2012-6-13\%20print.pdf.

Public Expenditure and Financial Accountability (PEFA). 2012. Pakistan Federal Government: Public Financial Management and Accountability Assessment. Report No. 69185-PK. Islamabad: World Bank Pakistan. https://openknowledge.worldbank.org/handle/10986/26816.

-_- Pakistan 2012. https://www.pefa.org/assessments/summary/1536.

Provincial Government of Punjab, Pakistan; Planning and Development Board, PPP Cell. Pipeline Projects. https://ppp.punjab.gov.pk/pipeline_projects (accessed 22 September 2020).

Project Digest. https://ppp.punjab.gov.pk/digest (accessed 8 September 2020).

Provincial Government of Punjab, Pakistan; Transport Department. 2014. Request for Proposal for the Establishment of Vehicle Inspection and Certification System in Punjab Pakistan. Lahore. https://www.punjab.gov.pk/system/ files/RFP_VICS_PRE-BID_03_01-2014.pdf.

Provincial Government of Sindh, Pakistan; Finance Department, PPP Unit. Projects in Pipeline. http://www. pppunitsindh.gov.pk/projects_new.php?pid=29\&pstatus=Pipeline (accessed 22 September 2020). 
RIAA Barker Gillette. 2020. In Brief: Arbitration Formalities in Pakistan. Lexology. 16 June. https://www.lexology. com/library/detail.aspx?g=04064317-ff25-4a12-945c-5be1bd761f25.

The Airport Authority. List of all Airports in Pakistan. https://airport-authority.com/browse-PK.

The Economist Intelligence Unit. Infrascope 2018: Pakistan Country Profile. https://infrascope.eiu.com (accessed 1 September 2020).

The Global Economy. Compare Countries. https://www.theglobaleconomy.com/compare-countries/ (accessed 10 September 2020).

- - - Education Spending, Percent of Government Spending-Country Rankings. https://www. theglobaleconomy.com/rankings/Education_spending_percent_of_government_spending/ (accessed 10 September 2020).

- - - Energy Imports. https://www.theglobaleconomy.com/rankings/Energy_imports/ (accessed 10 September 2020).

- - - Health Spending per Capita_Country Rankings. https://www.theglobaleconomy.com/rankings/Health_ spending_per_capita/ (accessed 10 September 2020).

-_- Internet Bandwidth. https://www.theglobaleconomy.com/rankings/Internet_bandwidth/ (accessed 10 September 2020).

- - - Internet Subscribers. https://www.theglobaleconomy.com/rankings/Internet_subscribers_per_100_ people/ (accessed 10 September 2020).

- - - Mobile Network Coverage. https://www.theglobaleconomy.com/rankings/Mobile_network_coverage/ (accessed 10 September 2020).

- - - Mobile Phone Subscribers. https://www.theglobaleconomy.com/rankings/Mobile_phone_subscribers_ per_100_people/ (accessed 10 September 2020).

- - - Port Traffic-Country Rankings. https://www.theglobaleconomy.com/rankings/Port_traffic/ (accessed 10 September 2020).

- - - Railroad Infrastructure Quality_Country Rankings. https://www.theglobaleconomy.com/rankings/ railroad_quality/ (accessed 10 September 2020).

- - - Railway Passengers - Country Rankings. https://www.theglobaleconomy.com/rankings/railway_ passengers/ (accessed 10 September 2020).

- - - Railway Transport of Goods_Country Rankings. https://www.theglobaleconomy.com/rankings/Railway_ transport_of_goods/ (accessed 10 September 2020).

- - - Share of Clean Energy-Country Rankings. https://www.theglobaleconomy.com/rankings/share_of_ clean_energy/ (accessed 10 September 2020).

Transparency International. Countries: Pakistan. https://www.transparency.org/en/countries/pakistan\# (accessed 18 September 2020).

United Cities and Local Governments (UCLG) and Organisation for Economic Co-operation and Development (OECD). 2016. Subnational Governments Around the World: Structure and Finance. Part III-Country Profiles. 
A joint study of UCLG and OECD. https://www.uclg.org/sites/default/files/global_observatory_of_local_ finance-part_iii.pdf.

United Nations General Assembly. 2012. National Report Submitted in Accordance with Paragraph 5 of the Annex to Human Rights Council Resolution 16/21: Pakistan. https://www.upr-info.org/sites/default/files/document/ pakistan/session_14_-_october_2012/ahrcwg.614pak1e.pdf.

VIS Credit Rating Company Limited. https://www.vis.com.pk/about.aspx.

World Bank. Data. Access to Electricity. https://data.worldbank.org/indicator/eg.elc.accs. $z s$ ? end=2018\&locations=mm-kh-uz-cn-bd-ge-in-id-kz-pk-ph-lk-th-vn\&start=2018\&view=bar (accessed 2 December 2020).

- - Data. Air Transport Passengers Carried. https://data.worldbank.org/indicator/is.air.psgr?locations=bdkhge-kz-mm-pk-pg-lk-uz-vn-cn-in-id-ph-th (accessed 2 December 2020).

- - Data. Fixed Telephone Subscriptions. https://data.worldbank.org/indicator/IT.MLT.MAIN. P2? end $=2018$ \&locations=MM-KH-UZ-CN-BD-GE-IN-ID-KZ-PK-PH-LK-TH-VN\&start=2018\&view=bar (accessed 2 December 2020).

- - Doing Business: Ease of Doing Business in Pakistan. https://www.doingbusiness.org/en/data/ exploreeconomies/pakistan (accessed 18 September 2020).

- - Doing Business. Ease of Doing Business Score-Getting Electricity. https://www.doingbusiness.org/en/ data/exploretopics/getting-electricity (accessed 2 December 2020).

- - L LPI Global Rankings 2018. https://pi.worldbank.org/international/global?sort=asc\&order=LPI\%20 Score\#datatable (accessed 18 September 2020).

- - . PPP Knowledge Lab. Pakistan. https://pppknowledgelab.org/countries/pakistan (accessed 18 September 2020).

World Port Source. World Ports by Country-Pakistan. http://www.worldportsource.com/countries.php (accessed 10 September 2020).

Worldometer. Pakistan Population. https://www.worldometers.info/world-population/pakistan-population/ (accessed 6 December 2020). 


\section{Public-Private Partnership Monitor Pakistan}

The Government of Pakistan strongly supports public-private partnerships (PPP) initiatives. From 1990 to 2019, Pakistan witnessed 108 financially-closed PPP projects, with a total investment of approximately $\$ 28.4$ billion. About $88 \%$ of these projects are in the energy sector, attracting more than $\$ 24.7$ billion of investments; these are followed by investments in the port sector. In early 2021, the parliament approved the amendments to the 2017 PPP Law, enacting the Public Private Partnership Authority (Amendment) Act 2021. This further strengthens the enabling legal and regulatory framework for developing and implementing PPPs, thereby promoting private sector investment in public infrastructure and related services.

\section{About the Asian Development Bank}

ADB is committed to achieving a prosperous, inclusive, resilient, and sustainable Asia and the Pacific, while sustaining its efforts to eradicate extreme poverty. Established in 1966, it is owned by 68 members -49 from the region. Its main instruments for helping its developing member countries are policy dialogue, loans, equity investments, guarantees, grants, and technical assistance. 